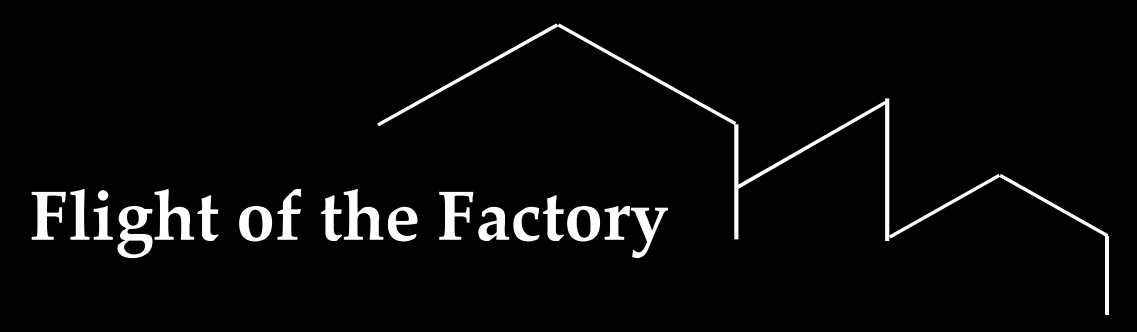

\author{
Design guidelines for the use of laminated \\ timber in the adaptive reuse of unreinforced \\ masonry industrial heritage buildings in rural \\ New Zealand
}

Mark Jonathon Lovelock 


\section{Flight of the Factory}

by

Mark Jonathon Lovelock

A thesis

submitted to the Victoria University of Wellington

in fulfilment of the requirements for the

Masters of Architecture (Professional)

\section{Victoria University of Wellington}

2018 


\section{Acknowledgments}

Chris McDonald, a fountain of knowledge.

Wayne and the generous people of Tokomaru Bay.

Friends and Family

The Stable, Mudges and 289

Emma for your support, near and far. 


\section{Abstract}

New Zealand's industrial heritage is largely forgotten and at risk of being lost. Without intervention, these buildings will continue to decay untildemolition becomes the only feasible option. This design research investigates how laminated timber can be used to adaptively reuse industrial heritage buildings. Adaptive reuse allows a new programme to occur within an existing heritage site, while simultaneously acknowledging its significance. This research produces a set of design guidelines and strategies that can be used to inform future projects.

Laminated timber is typically used in the construction of new buildings, and is becoming an increasingly popular choice of material due to recent technological developments and its sustainable profile. This design research explores the use of laminated timber within the adaptive reuse of industrial heritage buildings as an alternative to typical strengthening materials, such as steel and concrete.

The ruins of the Tokomaru Bay Freezing Works is used as a design case study to explore the research question. Located $90 \mathrm{~km}$ north of Gisborne, Tokomaru Bay is a typical example of the boom and bust experienced in the primary industries of provincial New Zealand during the 20th century. Constructed from Unreinforced Masonry (U.R.M), the freezing works opened in 1910 and initially brought prosperity and development to the region. After the factory's closure in 1952, the freezing works was abandoned and quickly fell into disrepair and the Tokomaru Bay community sharply declined. This design case study aims to explore the contribution of laminated timber within the adaptive reuse of U.R.M in the context of a Mānuka honey factory and garden nursery, within the ruins of the Tokomaru Bay Freezing Works.

Using strategies identified throughout the design research, this case study shows the beneficial relationship that can be achieved between the use of new (laminated timber) and existing heritage fabric (U.R.M) that is compatiblewitheconomicrevitalisation of small town New Zealand. While acknowledging the limitations of laminated timber, this research identifies five design criteria; architectural character, structure, heritage significance, envelope and program, to assess the success of the design strategies identified. 


\section{Contents}

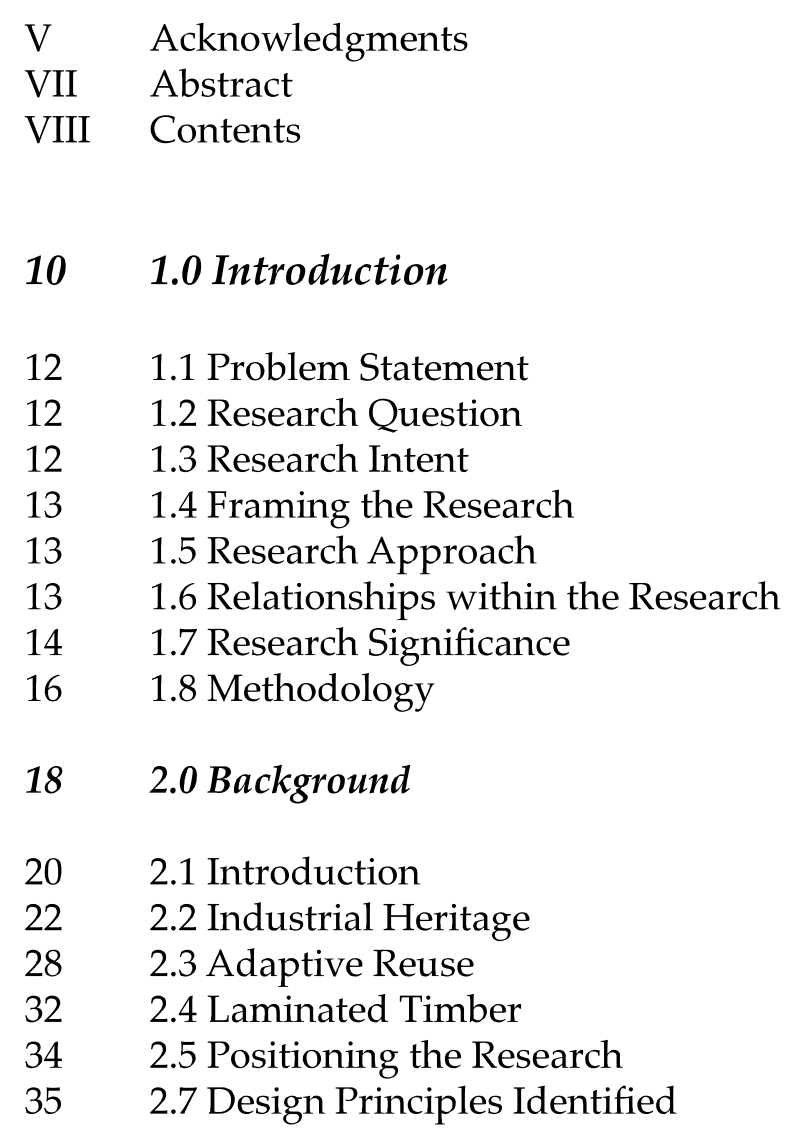

3.1 Introduction

3.2 Site Selection

3.3 Site Location

3.4 East Coast Region

3.5 Tokomaru Bay

3.6 Waima Cove Then and Now

3.7 History of the Land

3.8 East Coast Freezing Works Industry

3.9 Freezing Works Ruins

3.10 Masonry Condition

3.11 Selected Site Analysis

$66 \quad 3.12$ Conclusions

\section{8}

\subsection{Programme Analysis}

4.1 Introduction

4.2 Programme Selection

4.3 Programme Considerations

4.4 Programme Background

4.5 Relationships within the Research

4.6 Conclusion

\subsection{Design Iterations}

5.1 Introduction

5.2 Design Iterations

5.2 Precedent Analysis

5.3 Identify Design Strategies

5.4 Initial Design Strategy Application

5.5 Initial Design Concept

5.6 On-Site Strategy Development

5.7 Developed Design

5.8 Final Design Guidelines 
116

6.1 Introduction

6.2 Master Plan

6.3 Urban Design

6.4 Site Plan

6.4 Axonometric Site Plan

6.5 Honey Factory Floor Plans

6.6 Long Section

6.7 Exterior Envelope

6.8 Interiors

6.9 Details
$134 \quad 7.0$ Exegesis

1367.1 Introduction

1367.2 Suitability of Case Study

$136 \quad 7.3$ Overall Design Approach

137 7.4 Design Assessment

141 7.5 Conclusion

\subsection{Conclusion}

$144 \quad 8.1$ Introduction

$144 \quad 8.2$ Key Findings

145 8.3 Research Reflection

1458.4 Closing Statement

146 8.5 Final Design Guidelines
9.1 References

9.2 List of Figures

9.3 Appendices 


\subsection{Introduction}




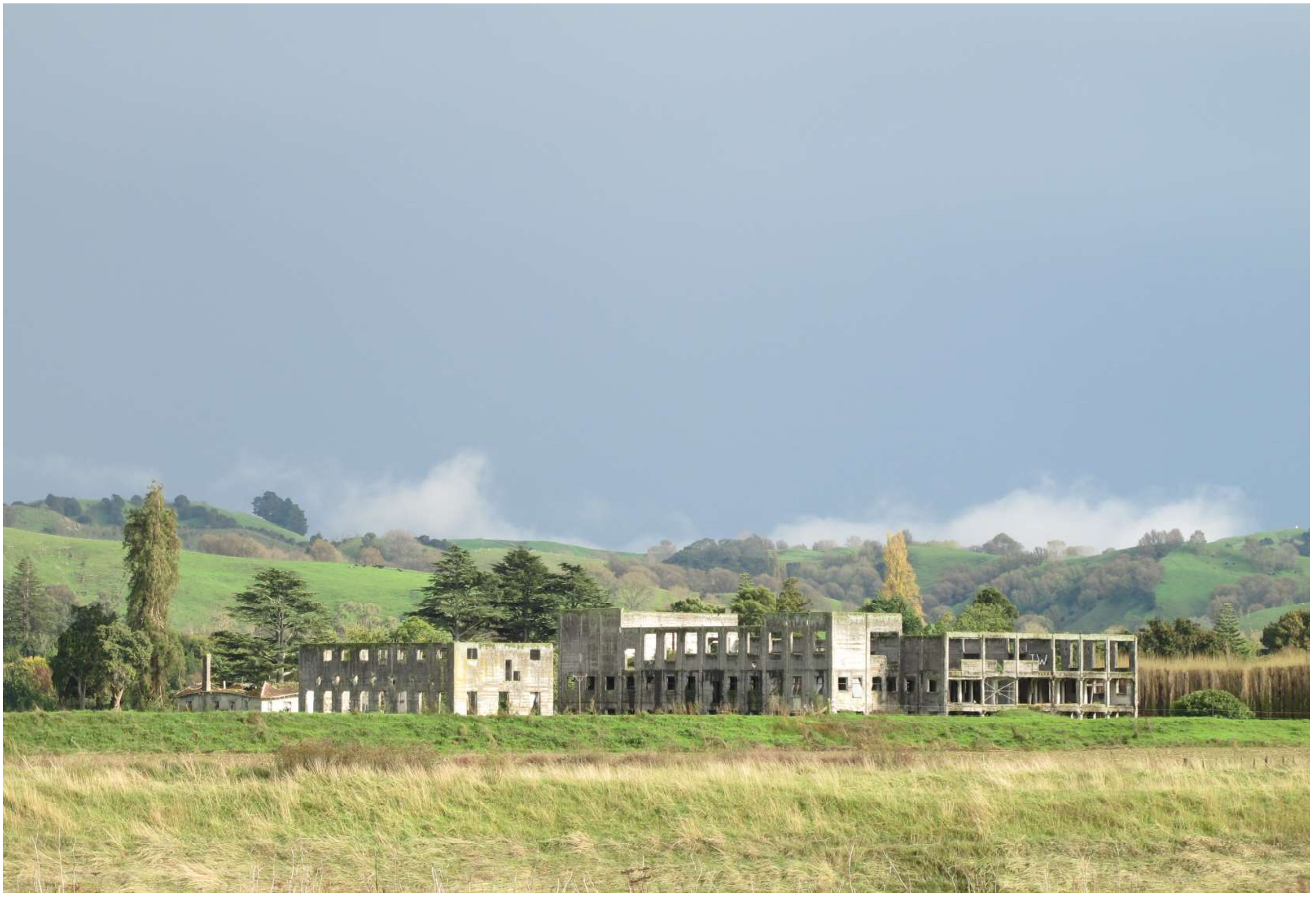




\subsection{Problem Statement}

New Zealand's industrial heritage is in decay and at risk of being lost. Early industries and factories that were responsible for much of the growth and development of New Zealand lie in ruins around the country. These heritage sites are largely forgotten and neglected. Heritage sites located away from urban centres are most at risk, with rural townships in decline and struggling to remain relevant in the twenty first century.

Adaptive reuse allows a new programme to occur while acknowledging the heritage of the site. Adaptive reuse is a conservation strategy that can be used when other heritage approaches, such as conservation and preservation are not suitable.

\subsection{Research Question}

How can laminated timber be used in the adaptive reuse of unreinforced masonry industrial heritage buildings in rural New Zealand?

3 key areas:

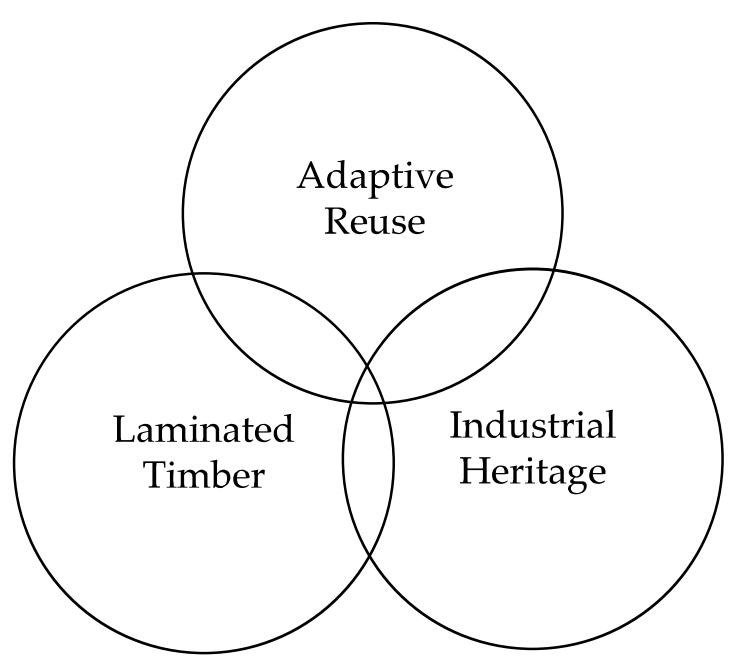

\subsection{Research Intent}

\subsubsection{Aim}

To produce a set of design guidelines that can inform future adaptive reuse projects about the integrated use of laminated timber within U.R.M industrial heritage buildings.

\subsubsection{Objectives}

An integrated response to the following five design criteria identified within the design research:

\section{Character}

Positive formal relationship between laminated timber and U.R.M.

\section{Structure}

Laminated timber to seismically strengthen U.R.M.

\section{Heritage}

Retain and enhance significance of heritage site.

\section{Envelope}

Re-establish building envelope

\section{Programme}

Laminated timber facilitates introduction of new production activity.

The final case study will be analysed against the design guidelines identified through the research to see if it meets these five criteria. 


\subsection{Framing the Research}

This research explores the material relationship between laminated timber and U.R.M industrial heritage buildings.

There are existing studies, both rural and urban that explore adaptive reuse of $\mathrm{New}$ Zealand's industrial heritage, however there are no existing studies that explore the use of laminated timber within the adaptive reuse of industrial heritage structures.

While applicable to all U.R.M industrial heritage sites, this research focuses only on frozen meat industry. For the purposes of the design case study, only freezing works on the East Coast region have been considered for analysis.

\subsection{Research Approach}

The research is split into 8 chapters. The introduction (1) and background (2) chapters lay the groundwork for the design research. Site analysis (3) and programme analysis (4) establish site specific parameters for the design case study. An iterative six-step design process (5), beginning with precedents and leading to the developed design, is followed by the final design (6). The exegesis chapter analyses the design case study (7) and conclusions (8) for the research is drawn.

\subsection{Relationships within the Research}

Adaptive reuse of heritage sites using laminated timber, creates relationships between old and new that will develop through the research.

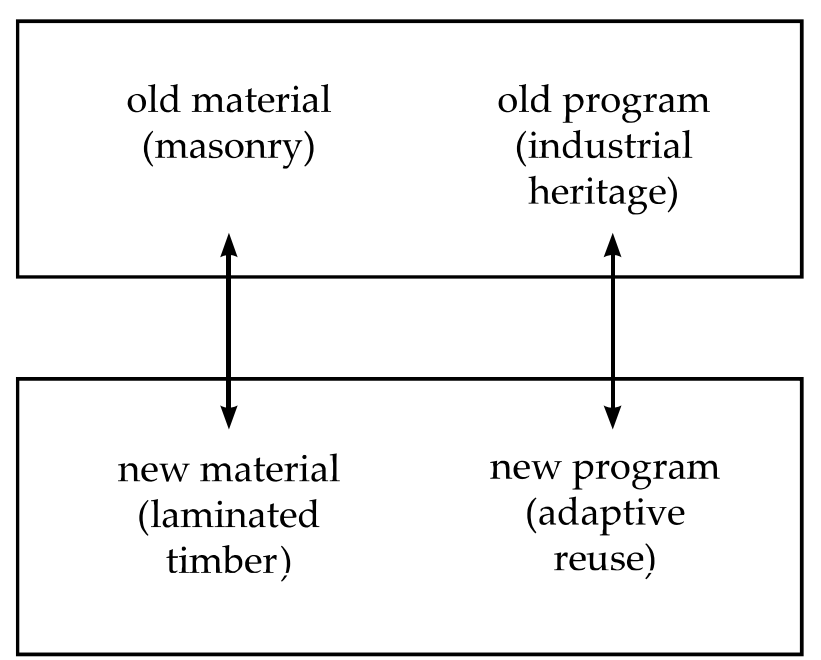




\subsection{Research Significance}

\subsubsection{Industrial Heritage:}

- Industrial heritage in New Zealand is at risk of being lost.

- The cultural value of these sites is extremely important to New Zealand.

- New Zealand should be pro-active in conserving its industrial heritage.

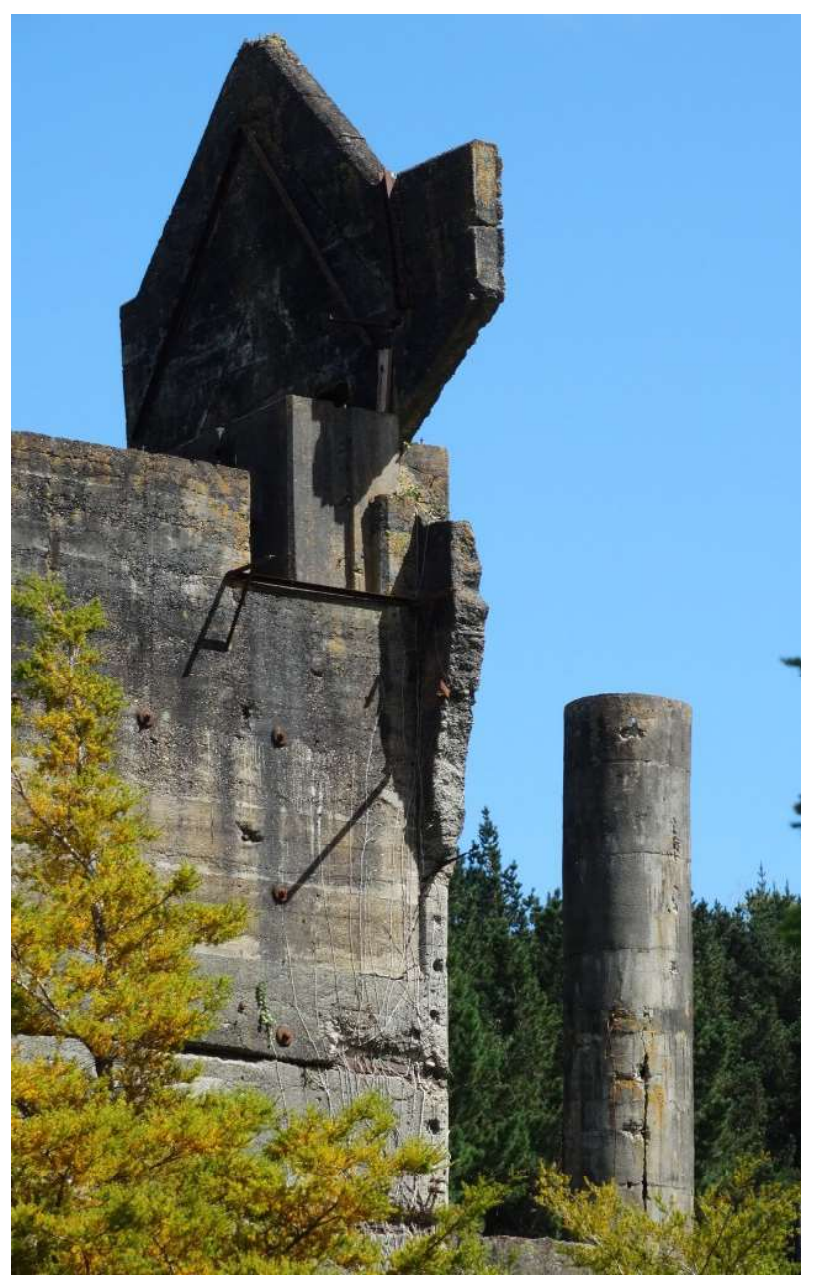

\subsubsection{Adaptive Reuse:}

- Adaptive reuse is a suitable method of conservation where other heritage strategies are not feasible.

- Promotes private investment in heritage sites that would not usually occur.

- Adaptive reuse of existing buildings has the potential to provide economic sustainability for struggling provincial townships in rural New Zealand. 


\subsubsection{Laminated Timber:}

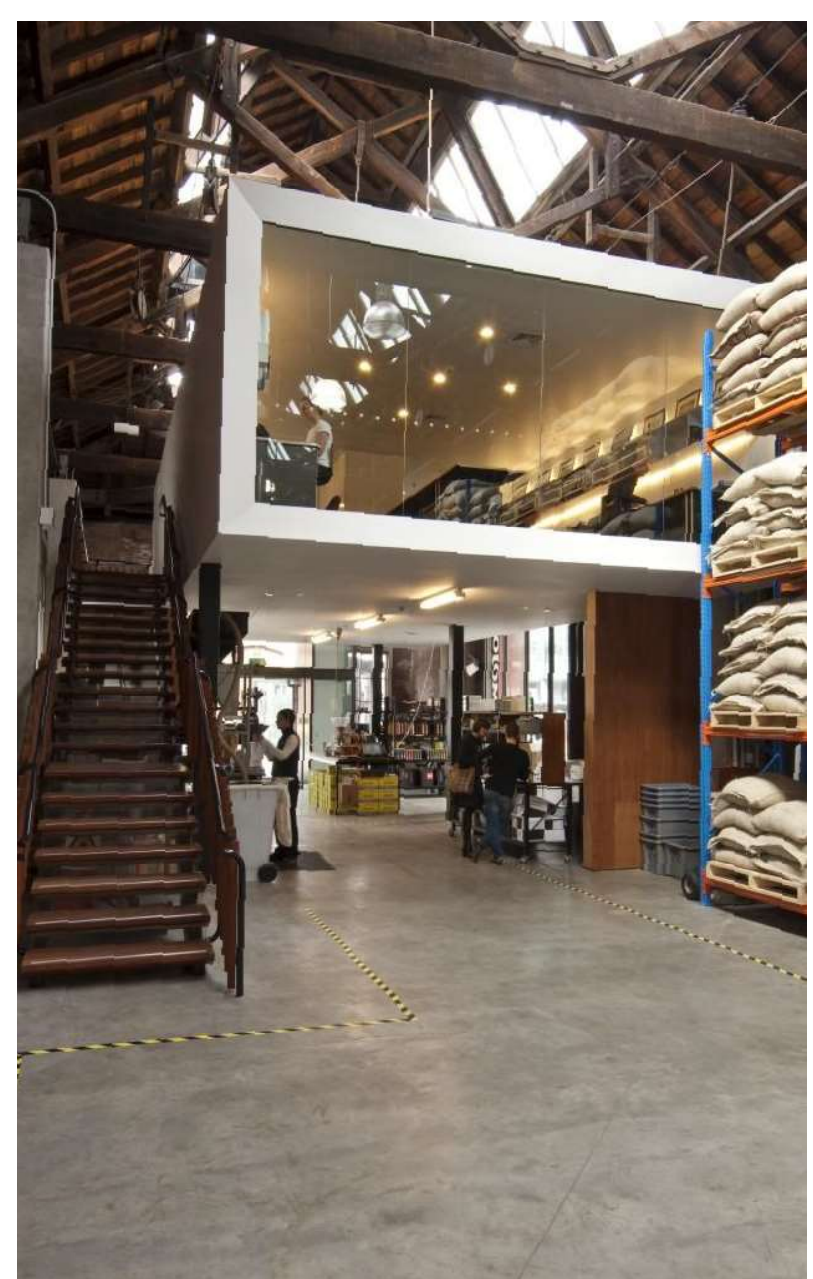

- Recent developments in laminated timber technology creates new design opportunities for the material.

- Research explores the potential compatibility of laminated timber and U.R.M as an alternative to current concrete/ steel seismic upgrades of U.R.M buildings.

- Timber grows well in New Zealand and is a sustainable and renewable resource.

- New Zealand has the potential to be a world leader in laminated timber technologies.

- Opportunity to develop a high-value export rather than low-value bulk commodity, which currently exists within the forestry industry.

- Promote the use of laminated timber as a material of the future.

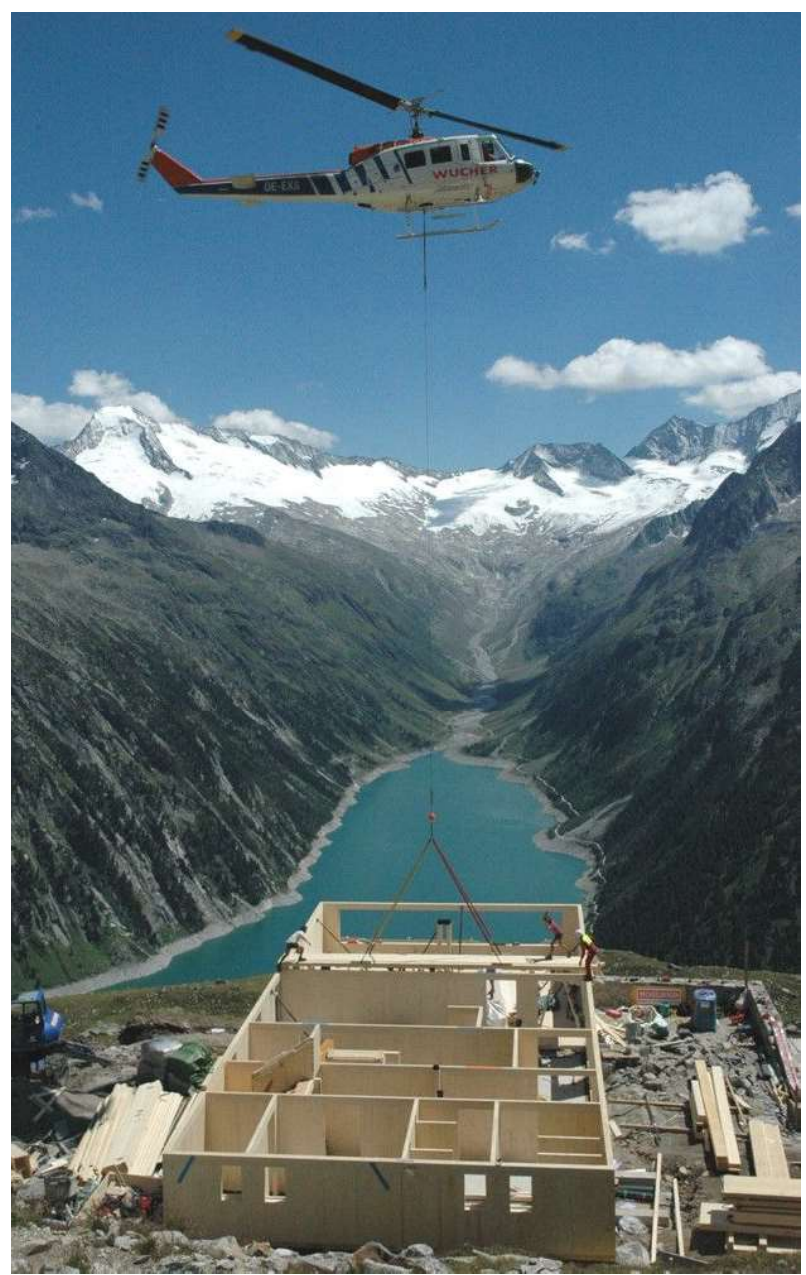




\subsection{Methodology}

The research question is explored through a six step iterative design process that culminates in the final design of the case study. The case study is then analysed against the design criteria identified throughout the research.

\section{Pre Design}

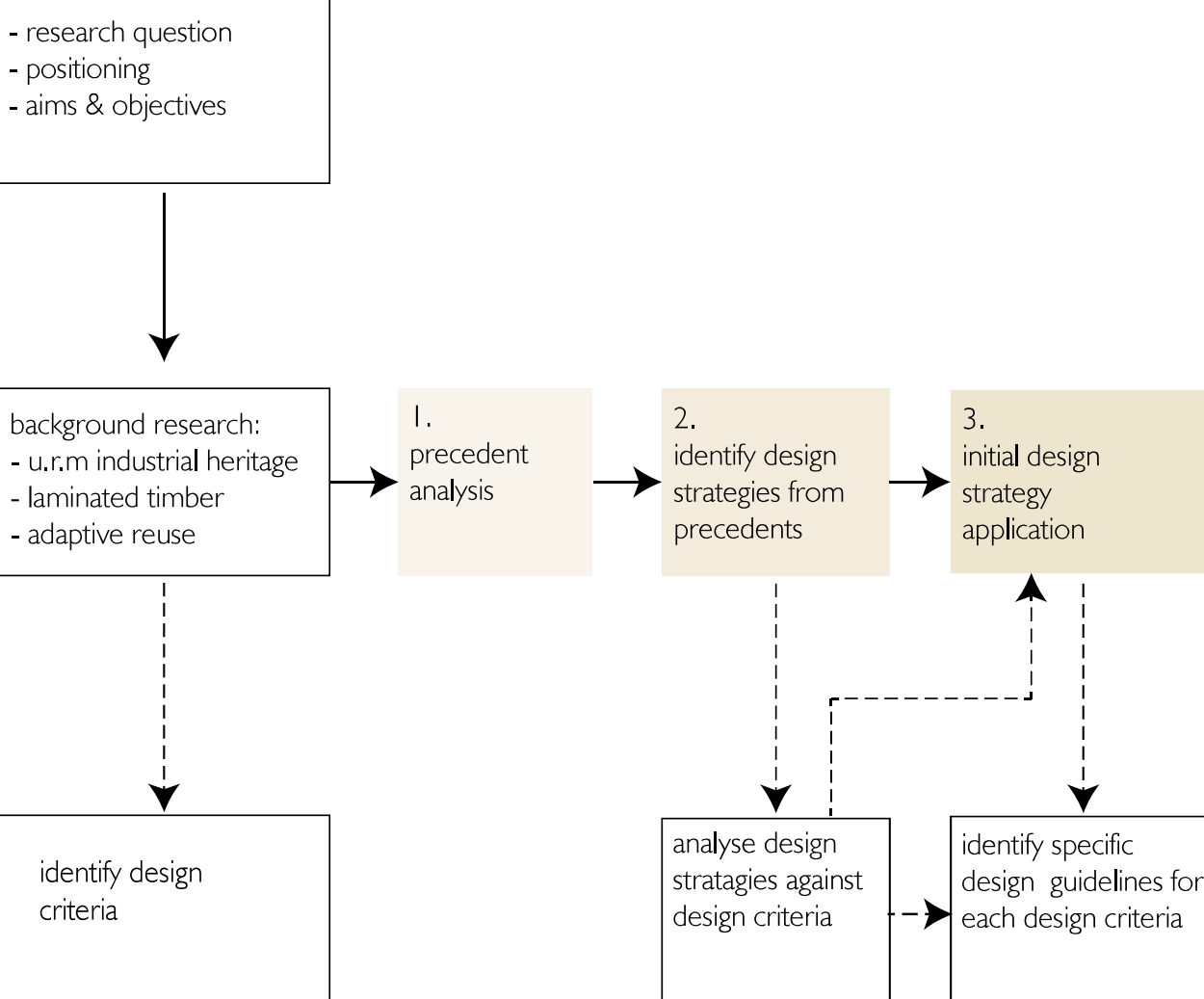


Design Case Study

site selection
site + context
analysis, freezin
works analysis

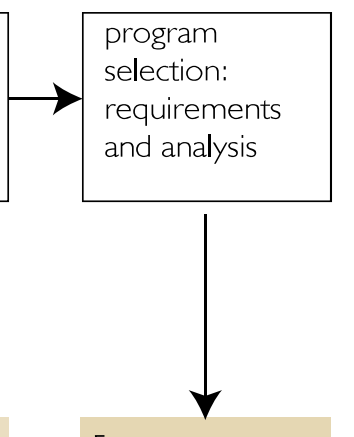

4.

initial design

concept

A

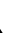

design strategy

development

on-site

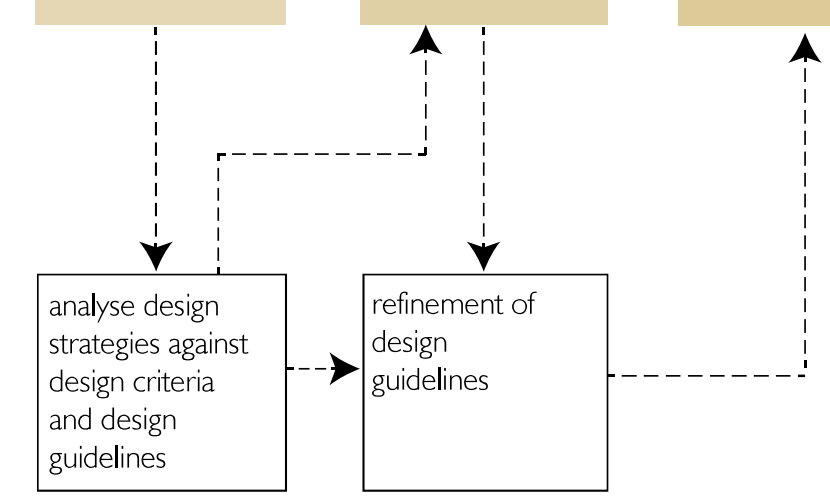

final design

\section{Post Design}

refine design

criteria and guidelines 
2. Background 
年

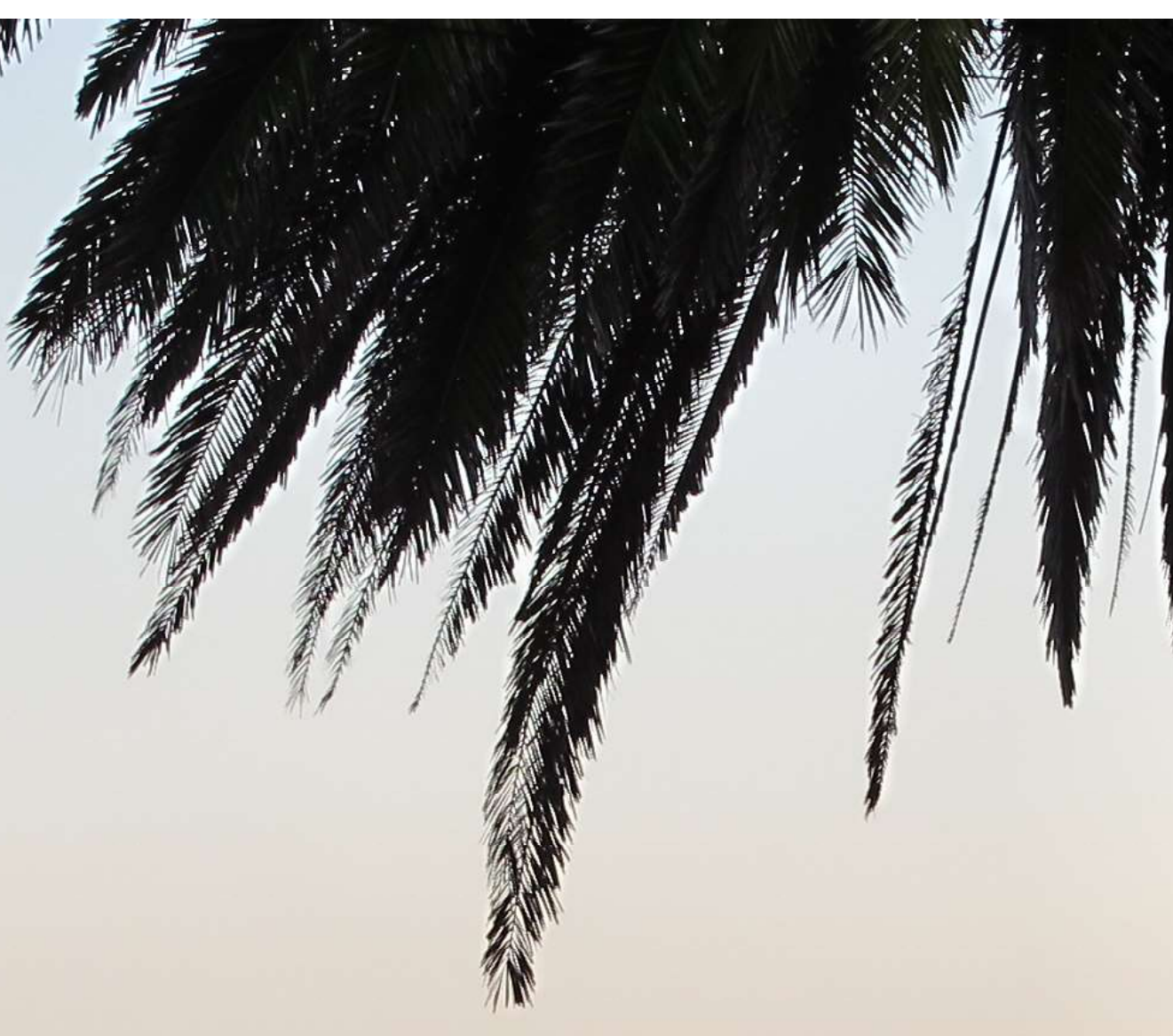




\subsection{Introduction}

This chapter provides a grounding platform to the 3 key topics within the research:

- Industrial Heritage

- Adaptive Reuse

- Laminated Timber

At the end of the chapter a positioning statement ties the topics to formulate how the research question will be approached. Where research has informed a design guideline this has been noted, an accumulative list is at the end of the chapter.

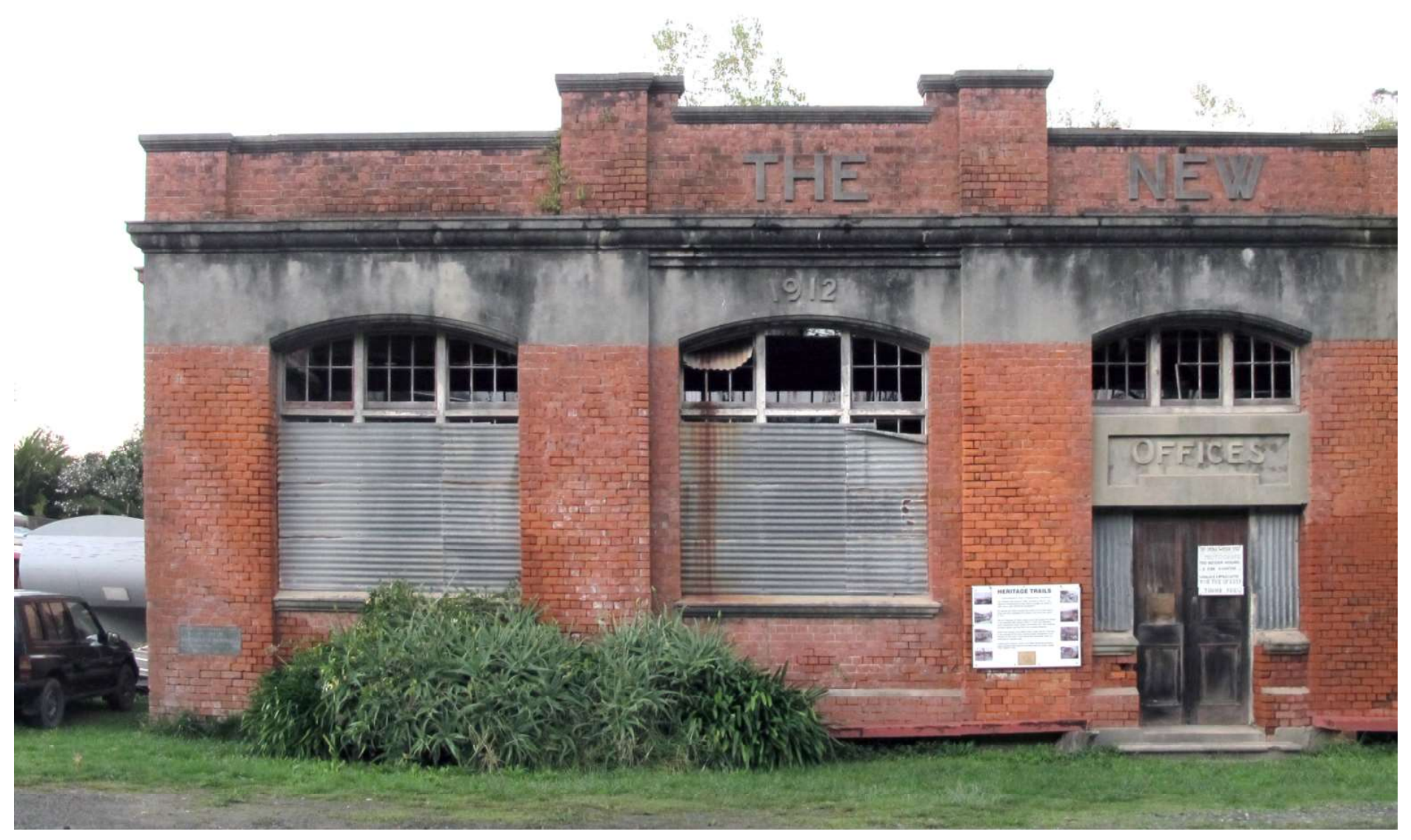




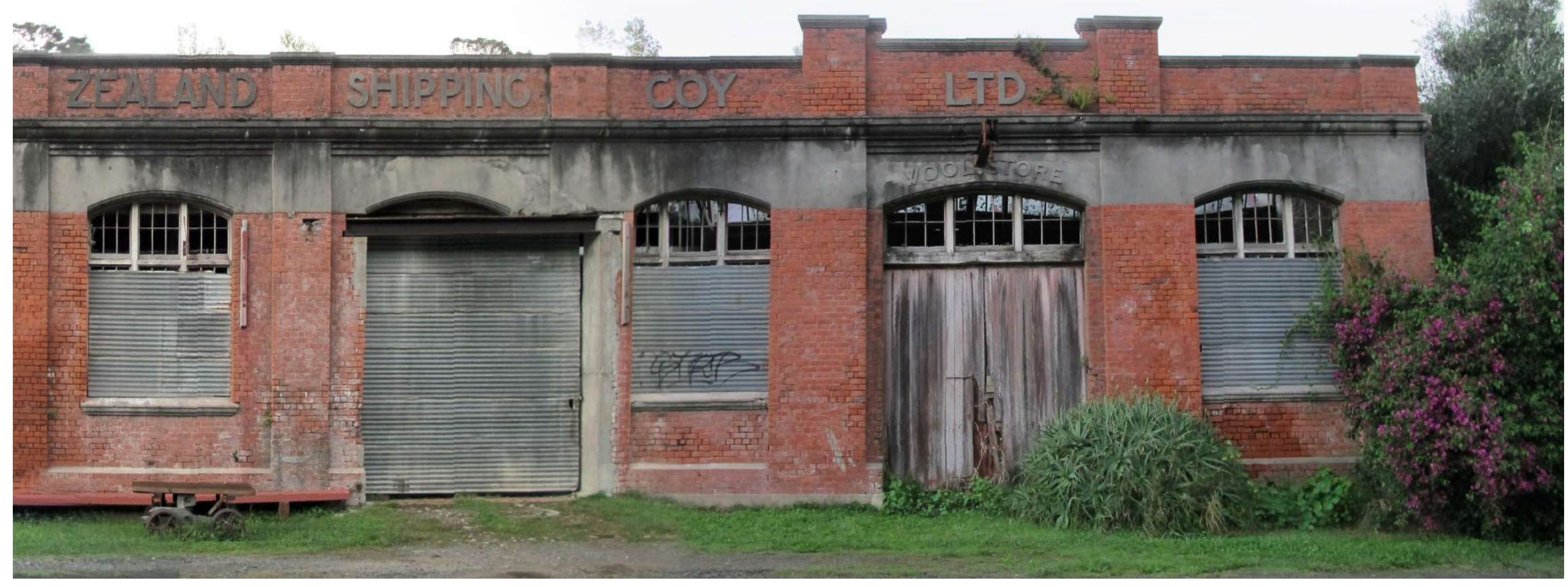




\subsection{Industrial Heritage}

\subsubsection{New Zealand's Industrial Heritage}

As a primary producing, agricultural nation, New Zealand's industrial heritage is not widely celebrated. While New Zealand "only had a small number of industries their impact has been significant, because they were responsible for much of our growth and development as a nation" (Thornton 1).

Early extractive industries, such as gold and timber were more transient due to the finite resource supply, as a result their structures were less permanent, and there are few structural remains.

The advent of industries, such as dairy and frozen meat accelerated the development of rural New Zealand, more permanent structures were constructed using timber, unreinforced masonry, and later reinforced concrete.

This design research focuses specifically on New Zealand's freezing works industry when addressing industrial heritage.

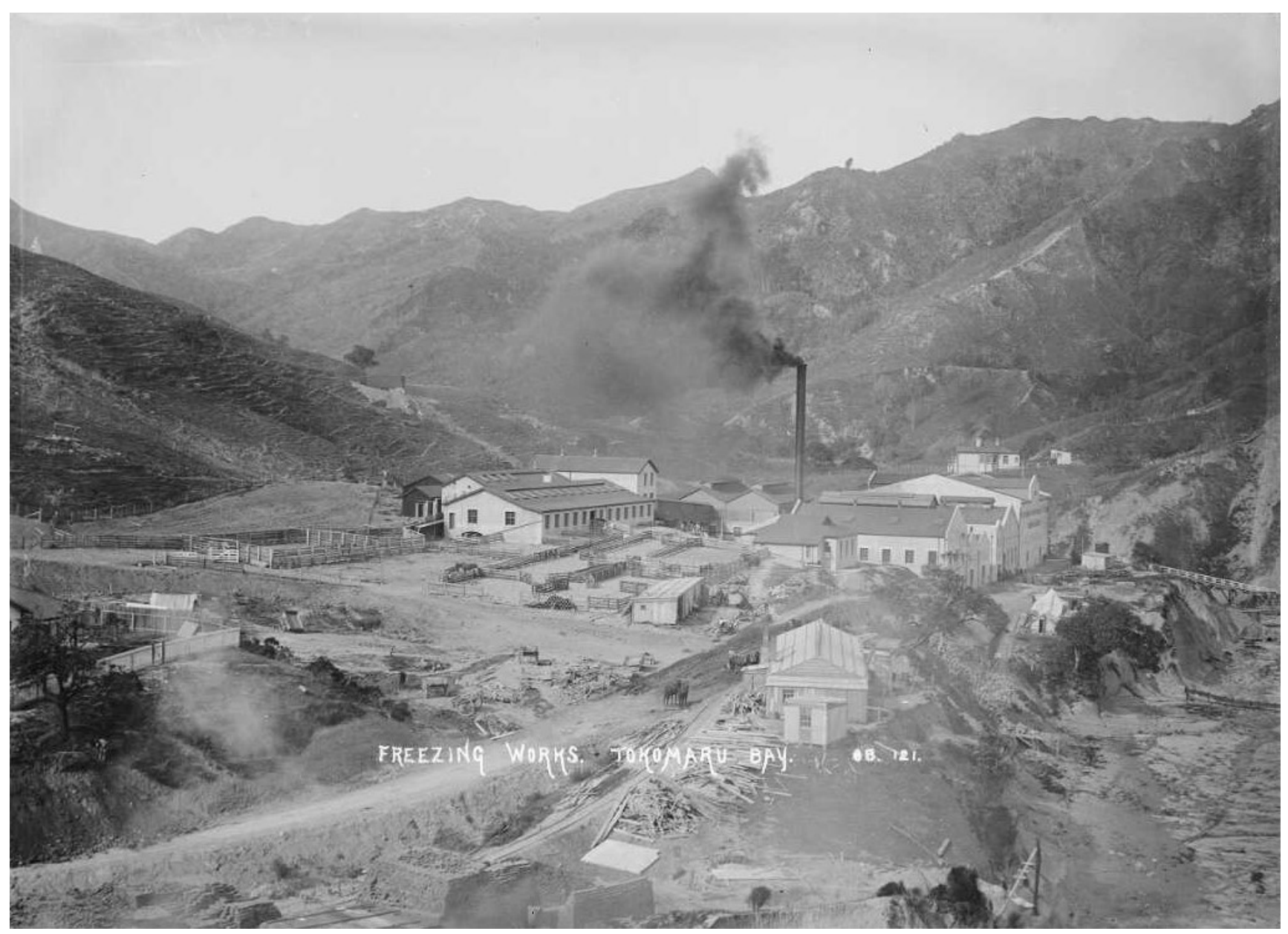




\subsubsection{Value of Industrial Heritage}

In the New Zealand Charter, the International Council on Monuments and Sites (ICOMOS) champions that the significance of place is based on an understanding and appreciation of all aspects of its cultural heritage value, both tangible and intangible. "This informs us about the past and the cultures of those who came before us and provides evidence of the continuity between past, present, and future. These sites reinforce community identity and relationships to ancestors and the land while providing a measure against which the achievements of the present can be compared" (ICOMOS).

"The loss of old buildings is now perceived not only as an ecological waste but also as the eradication of local identity, of cultural heritage and of socio-economic values" (Cramer and Breitling 9). When considered with the relative youth of New Zealand's built heritage the value of these structures is even more important. "New Zealand's U.R.M historic buildings form a rapidly diminishing aspect of the nation's collective heritage, which is a physical link to the past, and provides valuable evidence of cultural progression" (Goodwin, Tonks and Ingham 16).

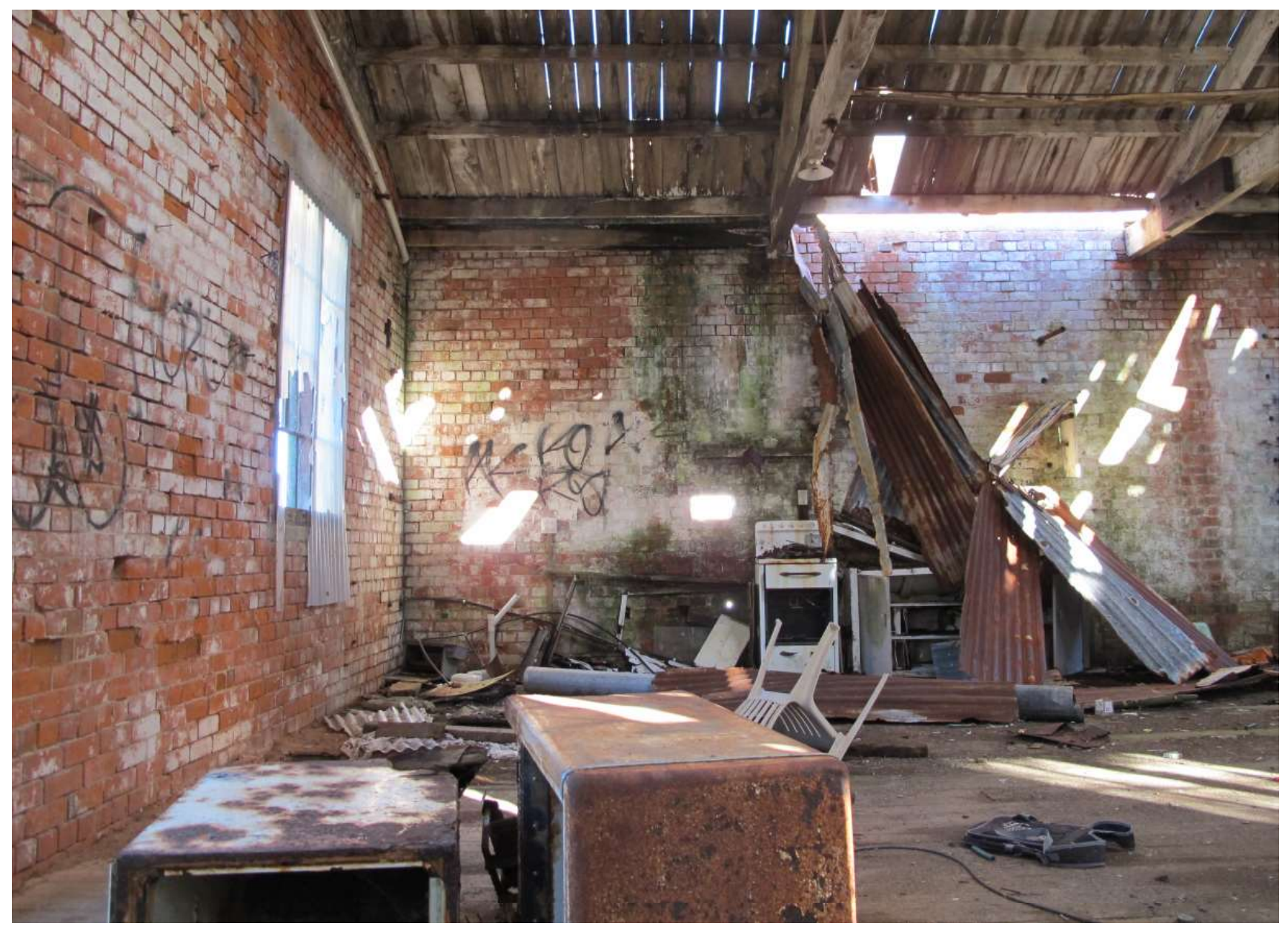

Figure 9 Tokomaru Bay Freezing Works ruins. Source: Author's Image 


\subsection{Industrial Heritage}

\subsubsection{Rise of the Frozen Meat Industry}

Before freezing works the 1870s and 1880s were known as the 'long depression', due to the collapse of international wool prices. Freezing works were a much needed technological development for an isolated country reliant on agricultural exports. Freezing works solved the oversupply of mutton on the domestic market, and sheep became valuable for both their wool and meat.

New Zealand's first freezing works opened in Dunedin in 1882, and by 1892 there were 21 freezing works around the country (Thornton 108). The advent of frozen shipping meant that previously isolated regions witnessed the fastest growth. "Not all New Zealand was logged. Much was wantonly incinerated. Bushburn established the farms of Taranaki, the central North Island and many other areas, but was both contentious and dangerous - though it certainly opened up the country for the great staples of New Zealand's export trade, frozen meat and dairy products" (Smith 13).

\subsubsection{Fall of the Freezing Works Industry}

The rapid rise of the freezing works industry was followed by a subsequent fall. Factories became untenable due to a number of factors, such as centraliasation, technological development, health and safety changes, and unsuitable farmland. Closures throughout the 20th century affected provincial New Zealand greatly. Rural communities that owed their prominence and economic existence to the frozen meat industry were faced with immediate decline. Freezing works in urban areas were demolished to free up land for new development. Freezing works in rural areas were stripped of salvageable material and the ruins left to decay.

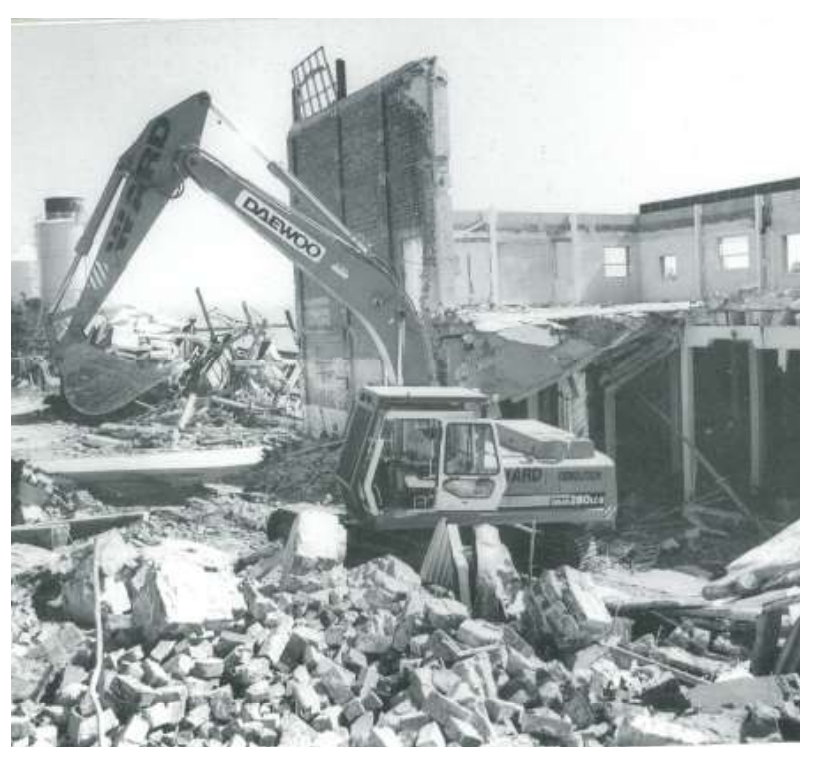

Figure 10 The end of an era. Kaiti Freezing Works began life in a small building used during the construction of the port's breakwater. Nearly a century later the works occupied most of a long, narrow site between the road and the hill. The old, outdated works was an industrial dinosaur, unable to successfully compete in the modern meat industry. Demolition in progress, May 1996.

Source: The Gisborne Herald 


\subsubsection{Solo Slaughtermen vs. The Chain}

In the first 50 years (1880-1930) of New Zealand freezing works highly skilled butchers, known as solo slaughtermen, carried out all the operations on the carcass.

The drive for efficiency in freezing works saw the development of the 'chain' in the 1930's. The chain carried carcasses through the freezing works and each worker carried out a specific operation on a carcass as it was brought it past them (Tolerton). Freezing works designed for solo slaughter men became outdated, and many works had to close as a result.
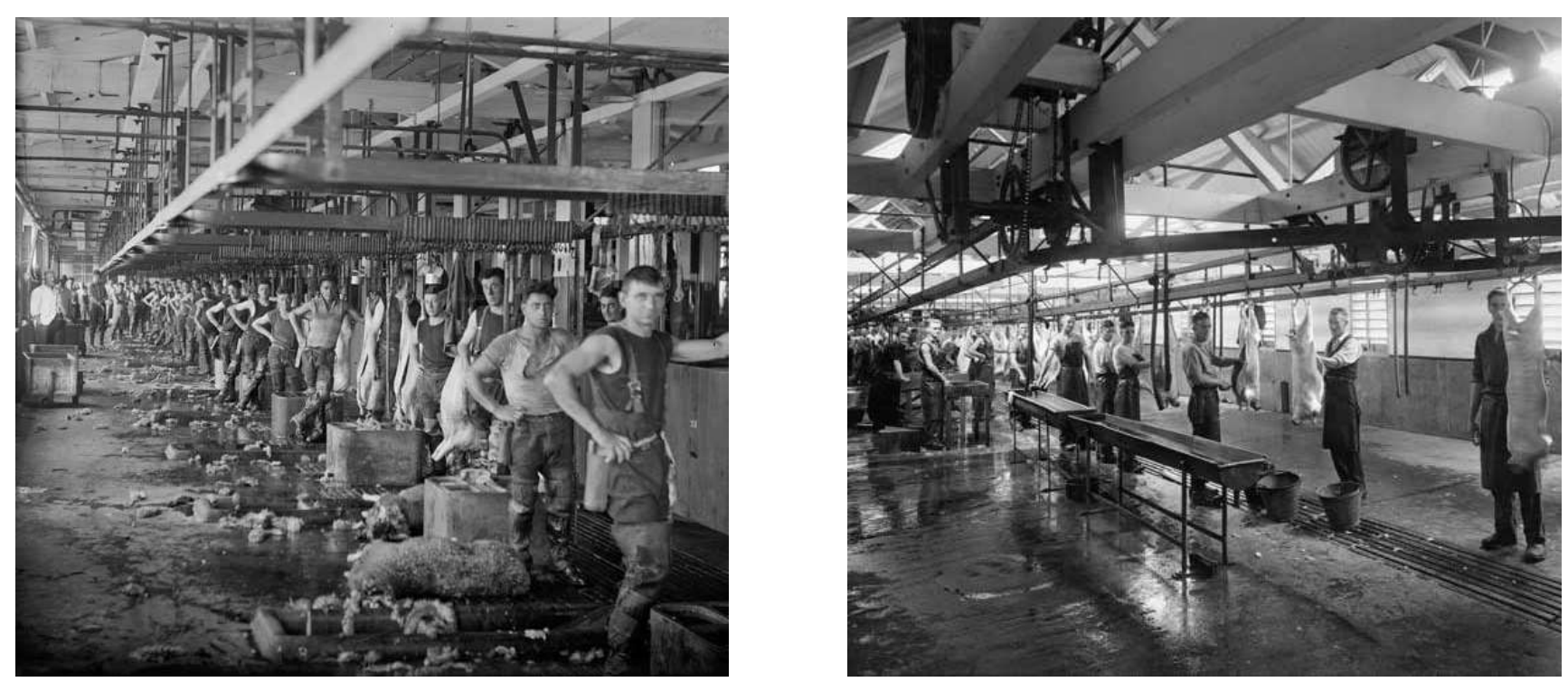

Figure 11 Solo Slaughtermen at Whakatu Freezing Works, Hastings. 1919.

Source: Alexander Turnbull Library
Figure 12 Butchers on a killing chain system. 1939. Source: Alexander Turnbull Library 


\subsection{Industrial Heritage}

\subsubsection{Freezing Works as Industrial Heritage}

Freezing works are an example of industrial buildings that hold cultural heritage value. These factories brought growth and prosperity to a country that built its reputation as an agricultural-export based nation. Now obsolete, these heritage listed buildings are either demolished or left to decay.

This industrial heritage is at risk of being lost, but there is opportunity to retain such significant places. "The challenge now is to cling on to what remains - it is often our only link with the sweat and toil, the ingenuity and risk taking, the lives of privation and misfortune that were the making of New Zealand" (Smith 15). The significance of early industries in New Zealand is deserving of recognition in the future.

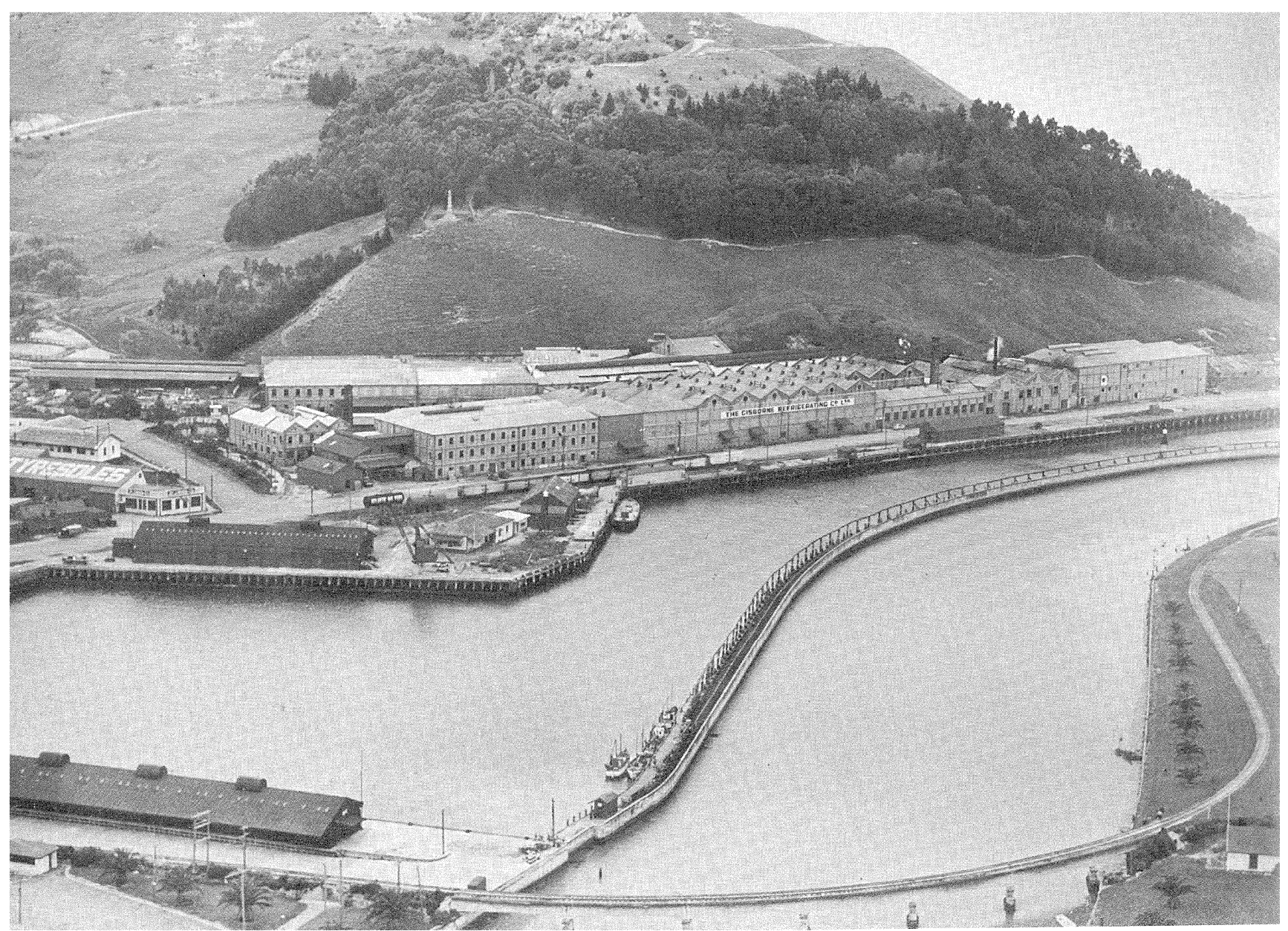

Figure 13 An aerial view of the sprawling Kaiti Freezing

Works, circa 1940

Source: Tairawhiti Museum 


\subsubsection{Typical U.R.M Strengthening Solutions}

These are examples of typical strengthening solutions to U.R.M buildings. The three most common methods are retrofitting structural steel, shotcrete (application of a layer of reinforced concrete to masonry wall) and fibre reinforcement.

These are practical solutions and the choice of method depends on the building. However, these methods can be unsuitable when considering heritage buildings, as they are unsympathetic, invasive and irreversible to the fabric of the existing building.
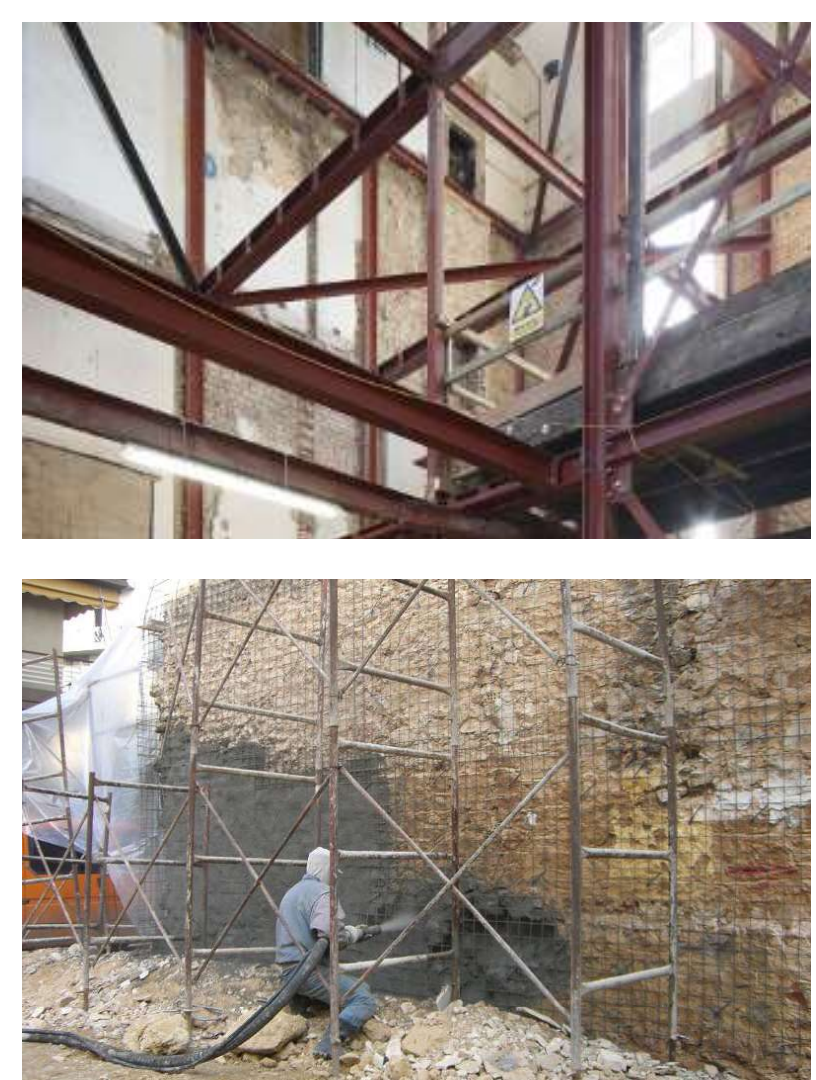

Figure 14 Steel portal structure reinforcing Source: CASE

Figure 15 Shotcrete being applied to masonry wall. Source: Epidomos Ltd

Figure 16 Fibre reinforced polymer reinforcing. Source: Tarek Alkhrdaji

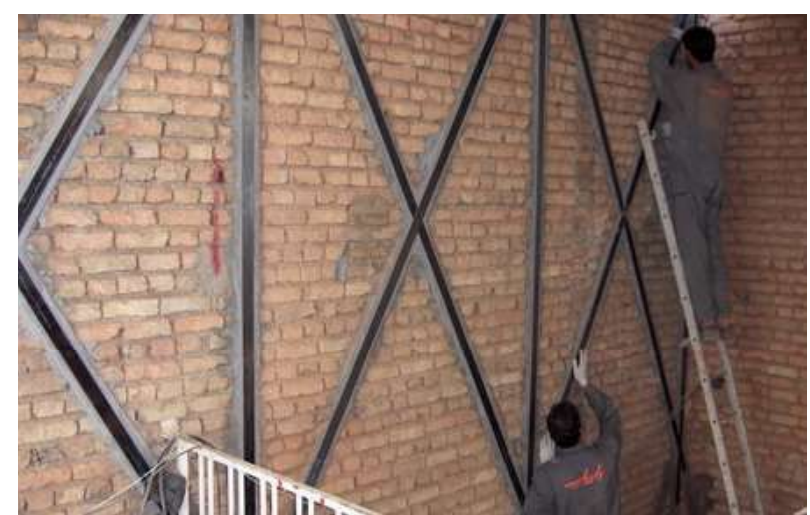




\subsection{Adaptive Reuse}

\subsubsection{What is Adaptive Reuse?}

Adaptive reuse is a strategy that allows a new programme to occur within an existing site.

As a strategy, adaptive reuse recognises the significance of a place, integrates a new programme appropriate to that significance, and reveals this significance through the design outcome. "Adaptive re-use gives new life to a site, rather than seeking to freeze it at a particular moment in time, it explores the options that lie between the extremes of demolition or turning a site into a museum. Adding a new layer without erasing earlier layers, an adaptive reuse project becomes part of the long history of the site" (Clarke).

Redundant industrial buildings are suitable candidates for adaption if their original purpose is obsolete and the building has outlived the purpose in which it was designed for.

\subsubsection{Heritage Conservation Approaches}

As a conservation strategy, adaptive reuse is at the end of the spectrum with the most change.

$\begin{array}{lll}\text { More Change } & \text { Adaptive Reuse } \\ \text { Less Change } & \text { Reconstruction } \\ \text { Restoration } & \\ \text { Preservation }\end{array}$

Adaptive reuse requires the designer to interpret how they will respond to the heritage significance of specific building to achieve a desired outcome. For example, Daniel Libeskind juxtaposes old and new to create a visually dynamic example of adaptive reuse. [design principle $1 A, 1 B$ ]

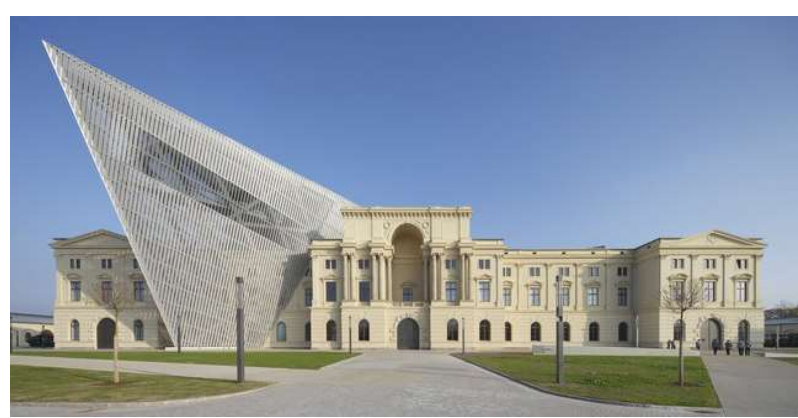




\subsubsection{Origins of Adaptive Reuse}

People have been reusing existing structures for hundreds of years, but the term adaptive reuse originated in the mid-20th century. "The challenge of using an old, often damaged, building as the basis and context for a new and ambitious design project was first taken up in modern times by architects rebuilding cities after the ravages of the Second World War" (Cramer and Breitling 97). This occurred during the height of the modern movement, adaptive reuse provided an alternative approach to the treatment of heritage buildings. "The issue is no longer about new versus old, but about the nature of the relationship between the two" (Powell 19). This view of designing with history was viewed as a "challenge to the radical ideals of modernism" (Powell 12). Architects such as Carlos Scarpa and Ricardo Bofill were champions of adaptive reuse.
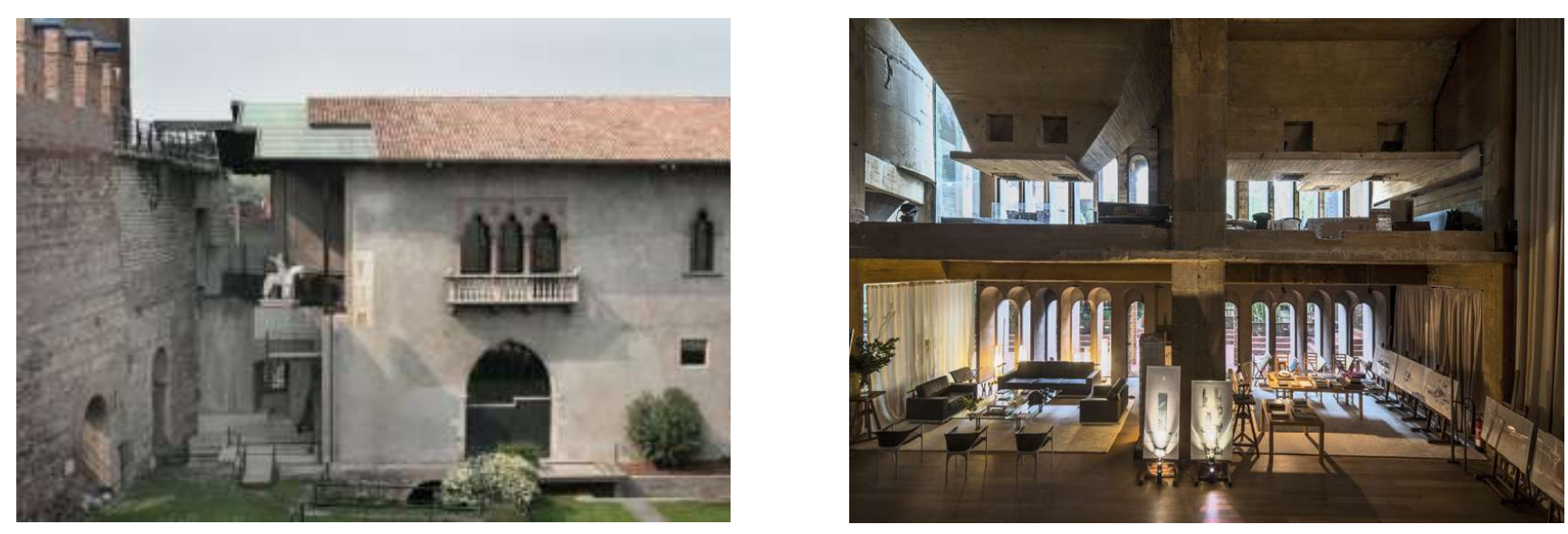

Figure 19 Ricardo Bofill's Cement Factory Conversion, Barcelona, Spain.

Source: DOMUS 


\subsection{Adaptive Reuse}

\subsubsection{Adaptive Reuse Guidelines}

Adaptive reuse is an established strategy used to approach heritage buildings. The Heritage Council of New South Wales lists the following guidelines for Adaptive Reuse:

1. Understand the significance of the place.

[design principle 3A]

2. Find a use which is appropriate to the heritage significance of the place.

[design principle 5A]

3. Determine a level of change which is appropriate to the significance of the place

4. Provide for the change to be reversed and for the place's future conservation.

[design principle 3B]

5. Conserve the relationship between the setting and preserve significant views to and from the heritage place.

[design principle $3 \mathrm{C}$ ]

6. Provide for the long-term management and viability of the heritage place.

[design principle $5 \mathrm{C}$ ]

7. Reveal and interpret the heritage significance of the place as an integral and meaningful part of the adaptation project.

[design principle 3D]

\subsubsection{Achieving Adaptive Reuse With Industrial Heritage}

Adaptive reuse is appropriate when a structure has outlived the purpose it was originally designed for. The main objective of adaptive reuse is to reveal the significance of a place while enabling a new program to occur, when successful this allows "associations between the place and people to remain" (Walker and Marquis-Kyle 68). Over time the new design and program can be viewed as adding "a further layer to the palimpsest of traces from previous times" (Cramer and Breitling 99). As opposed to the traditional conservation and preservation of heritage sites, adaptive reuse aims to show that it is "possible to successfully conserve and reuse heritage buildings to achieve high quality places that respond and contribute positively to the environment and still retain their heritage values" (Heritage Council of New South Wales 46 ).

While many would not consider industrial buildings architecturally significant, the significance of their heritage still needs to be expressed. "The advantages of adaptive re-use can be linked to memory and cultural value rather than built heritage. These buildings have typically helped to form the identity of a place" (Harrison, Clark and Mackay 2). Adaptive reuse turns upon the form/function dialectic. A conversion only succeeds when there is a good match between new function and existing form. Therefore it is necessary to analyse the existing build fabric before one can suggest a new use, because "out of the encounter between old envelope and new requirements, a unique object will be born - one which is no mere juxtaposition, but a synthesis from the point of view of both construction and architecture" (Robert 9)

Simply put, the most successful built heritage adaptive reuse projects are "those that best respect and retain the building's heritage significance and add a contemporary layer that provides value for the future" (Department of Environment and Heritage)

[design principle 3E]

Figure 20 Cement factory interpretation. Barcelona, 1973. Source: Ricardo Bofill 


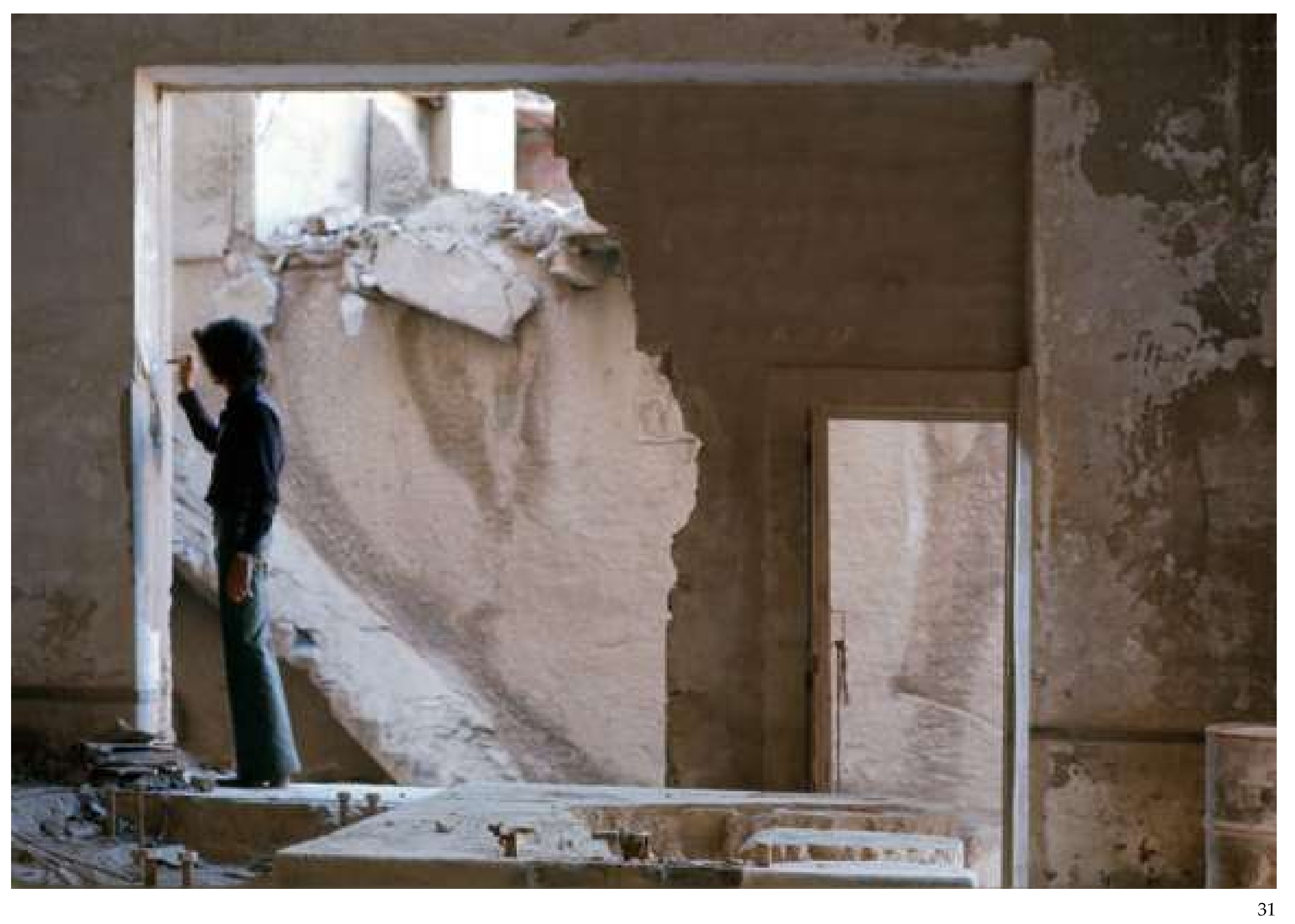




\subsection{Laminated Timber}

\subsubsection{What is Laminated Timber}

Laminated timber is a broad term for engineered wood products that are pressed together with adhesive to create structural timber members. There are different types of laminated timber depending on their material and structural composition. The three most common being cross laminated timber (C.L.T), glued laminated timber (glulam) and laminated veneer lumber (L.V.L).

Laminated timber is revolutionisng the way wood is used in the 21st century. The resurgence of timber can be attributed to new production methods and a shift toward sustainability. This has led the "development of more refined timber products" (Bejder 3). C.L.T is one such product where the "environmental and construction benefits make it a growth industry" (XLam). As a sustainable material, laminated timber has the potential to replace steel and concrete in buildings.

\subsubsection{Origins of Laminated Timber}

Laminated timber originated from Europe in the mid-20th century. Glulam has been around since the 1950's and as technology improved other laminated timbers developed. C.L.T is the most recent form of laminated timber, developed in Austria in the 1990's. Further developments in automation and digital technology, is establishing laminated timber as a more common building material.

In New Zealand, C.L.T research has started in the last decade and there has been increasing interest from researchers and practitioners in the material (Iqbal 1). Located in Nelson, XLam is currently the only factory in the southern hemisphere that produces C.L.T.

\subsubsection{Future of Laminated Timber}

Laminated timber is a revolutionary material with a bright future. "The 17th century was the age of stone, the 18th century was the peak of brick. The 19th century was the era of iron. The 20 th century was the century of concrete. The 21st century will be the time for timber" (de Rijke).

Laminated timber is generally used in the construction of new buildings. This research investigates the potential for laminated timber to be used in existing buildings, and how its properties allows a new programme to occur.

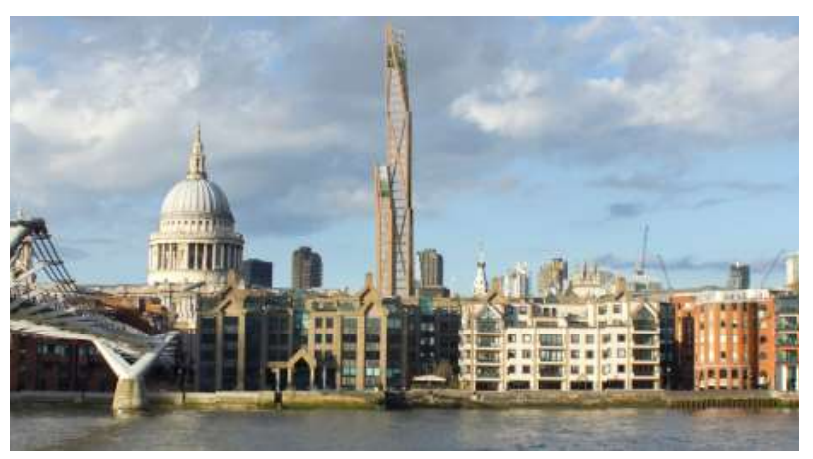




\subsubsection{Types of Laminated Timber}

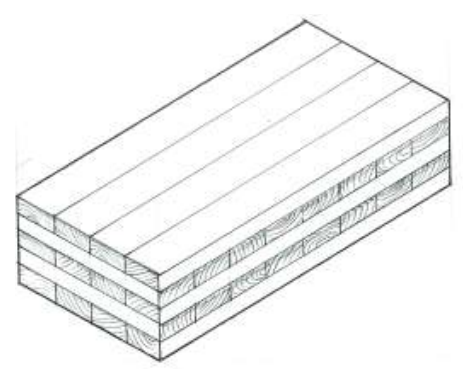

Figure 22 C.L.T Cross-section

Source: Author's Image

C.L.T consists of lengths of solid timber layered on top of each other in opposing directions. This creates a panel that has strength in both directions. C.L.T panels can be used for floors, wall and roofs. C.L.T panels can come in any size up to 15 metres long and 3.5 metres wide. Panel thickness depends on the intended load and span. The most common configurations have 3,5 or 7 layers, ranging in thickness from $60 \mathrm{~mm}-250 \mathrm{~mm}$.

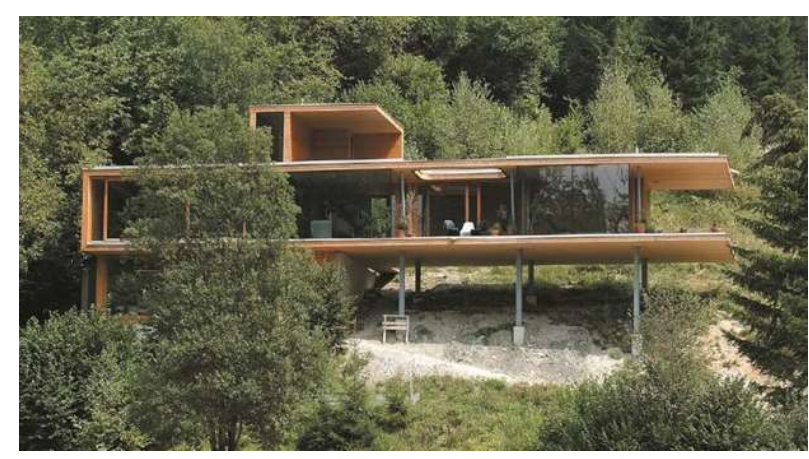

Figure 25 C.L.T House, Austria. Source: $K L H$

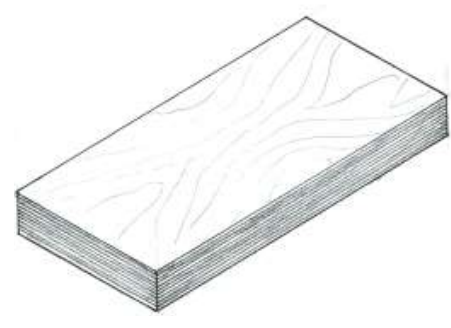

Figure 23 L.V.L Cross-section Source: Author's Image

L.V.L is created by laying up multiple thin sheets of veneered timber, the high number of laminations ensures that the product is of consistent strength through the length of the member. L.V.L can come on panels or beams.

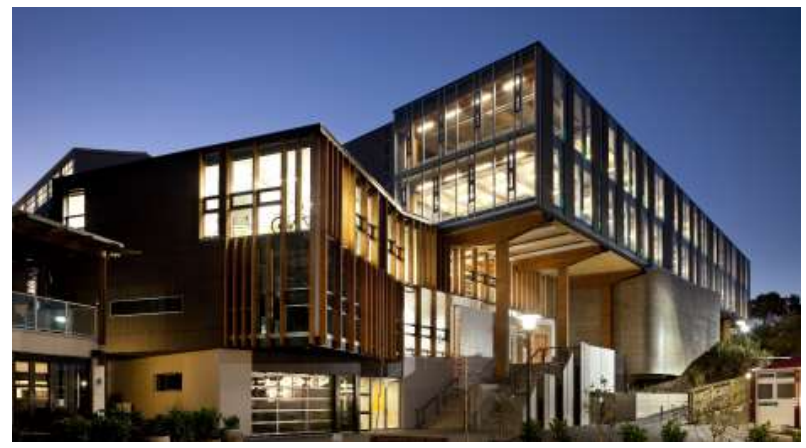

Figure 26 L.V.L in College of Creative Arts, Wellington Source: Nelson Pine

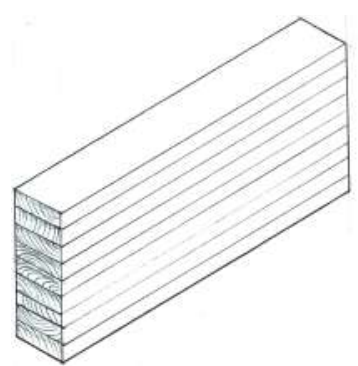

Figure 24 Glulam Cross-section Source: Author's Image

Glulam is lengths of timber running in the same direction laminated on top of each other and is used to create beams, columns and portal frames. Glulam members can be straight or curved and can span very large distances.

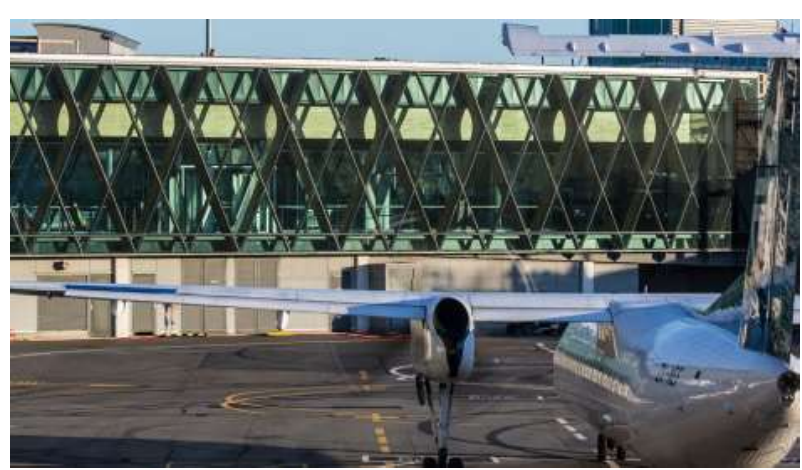

Figure 27 Glulam Structure, Airport Extension, Wellington Source: Warren + Mahoney 


\subsection{Laminated Timber}

\subsubsection{Properties of Laminated Timber}

Prefabricated members are manufactured to the buildings structural needs.

Laminated timber is strong and flexible under load, and weighs $20 \%$ of concrete for a similar structure (XLam)

Compared with natural timber, laminated timber offers longer spans, smaller member sizes, reduced natural defects (warping, twisting), and are more dimensionally accurate.

Natural properties of wood mean that laminated timber performs well in seismic loads.

Creates efficiencies on site as it speeds up the construction process. Digital precision means no waste on site, and no room for discrepancies.

C.L.T structures can also provide air-tightness, thermal insulation, internal moisture management, acoustic insulation and fire resistance (XLam).

Laminated timber stores carbon and is made from a renewable and sustainable resource.

Laminated timber can be expressed in the design to show structure of the building.

\subsection{Positioning the Research}

Integrating the three areas of the research together, provides a position that navigates the path of the research.

New Zealand's industrial heritage is under appreciated, and without intervention is at risk of being lost.

Adaptive reuse is one heritage conservation strategy that acknowledges significance of a building, while allowing a new programme to occur.

Construction benefits combined with its sustainable profile means that the use of laminated timber is growing and its application in the built environment is increasing.

Laminated timber is typically used in the construction of new buildings. This research explores the how laminated timber can be integrated into existing U.R.M heritage buildings.
In order for this to be successful the research will need to respond to the following design criteria:

- Architectural character

- Structural integration

- Heritage

- Building Envelope

- Programme integration

The introduction of this new material into existing industrial heritage buildings creates new design opportunities. The design case study will explore the material relationship between U.R.M and laminated timber, and the successfulness will be determined by how it meets these criteria. 
Design principles identified within the chapter are listed. These principles contribute to the aim of the research, which formulates a set of design guidelines.

\section{Character}

Positive formal relationship between laminated timber and U.R.M.

\section{1a. Form}

Establish a formal relationship that achieves a unified composition while also distinguishing between laminated timber and U.R.M.

\section{1b. Identity}

Laminated timber should be identifiable from the exterior to identify the buildings new use.

\section{Structure}

Laminated timber to seismically strengthen U.R.M.

\section{Heritage}

Retain and enhance significance of heritage site.

3a. Understand + Acknowledge Understand the significance of the U.R.M industrial heritage site before designing. Determine a level of change that acknowledges the significance of the site.

\section{3b. Reversibility}

Allow for the changes within the site to be reversed (this allows the opportunity for future interpretations of the heritage.

\section{3c. Context}

Conserve relationship between the U.R.M industrial heritage building and its setting. This preserves significant views to and from the U.R.M industrial heritage site.

\section{3d. Reveal Significance}

Reveal and interpret the heritage of the site through adaptive reuse.

\section{3e. Add Significance}

Introduce a program that builds on the existing heritage of the site and contributes to the heritage of the site in the future.

\section{Envelope}

Re-establish building envelope.

\section{Programme}

Laminated timber facilitates introduction of new production activity.

\section{5a. Programme Selection}

Select a program that allows the U.R.M industrial heritage site to be adaptively reused.

\section{5b. Function}

Use laminated timber to meet individual spatial requirements of new program within U.R.M site.

\section{5c. Versatility}

Allow for future expansion and development of the site. Buildings should be adaptable enough allowing future change in use. 


\subsection{Site Analysis}




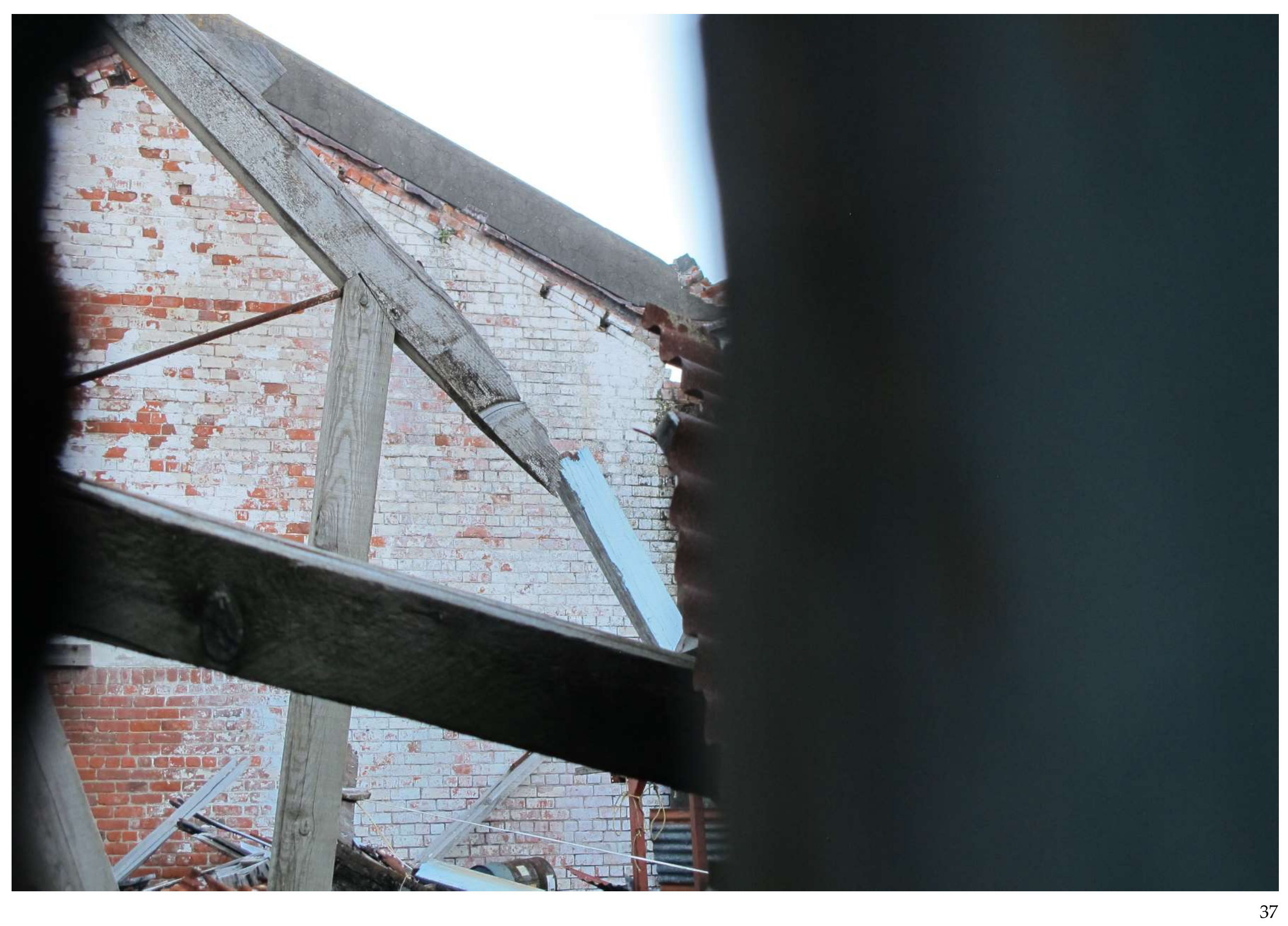




\subsection{Introduction}

This chapter includes a wide range of research that contributes to the analysis of the selected site, the Tokomaru Bay Freezing Works Ruins.

The site analysis evolved through the period of the research in preparation for the design case study, and is interconnected through geography, history and culture. The sections aim to develop a wholesome picture of the site and its wider context.

This chapter includes:

1. Analysis of East Coast and regional context.

2. Analysis of Tokomaru Bay community.

3. Comparative analysis of 5 East Coast Freezing works.

4. Heritage significance analysis of the site.

5. Site specific analysis of the Tokomaru Bay Freezing Works.

6. Discussion of key findings from the site analysis.

\subsection{Site Selection}

Tokomaru Bay Freezing Works is a typical example of a rural industrial heritage building in decay, making it suitable to explore the research question. "If there was ever an example of how the rise and fall of an industry could affect an entire community, it can be found in Tokomaru Bay" (Gundry 86).

Located $90 \mathrm{~km}$ North of Gisborne, the rural township of Tokomaru Bay is typical of the boom and bust experienced in the primary industries of provincial New Zealand during the 20th century. Constructed from U.R.M, the freezing works opened in 1910 and initially brought prosperity and development to region. After the factory's closure in 1952, the freezing works was abandoned and quickly fell into disrepair and the Tokomaru Bay community sharply declined. Today, the freezing works are in ruins, and the heritage largely forgotten. The township has few job opportunities and high rates of unemployment. 


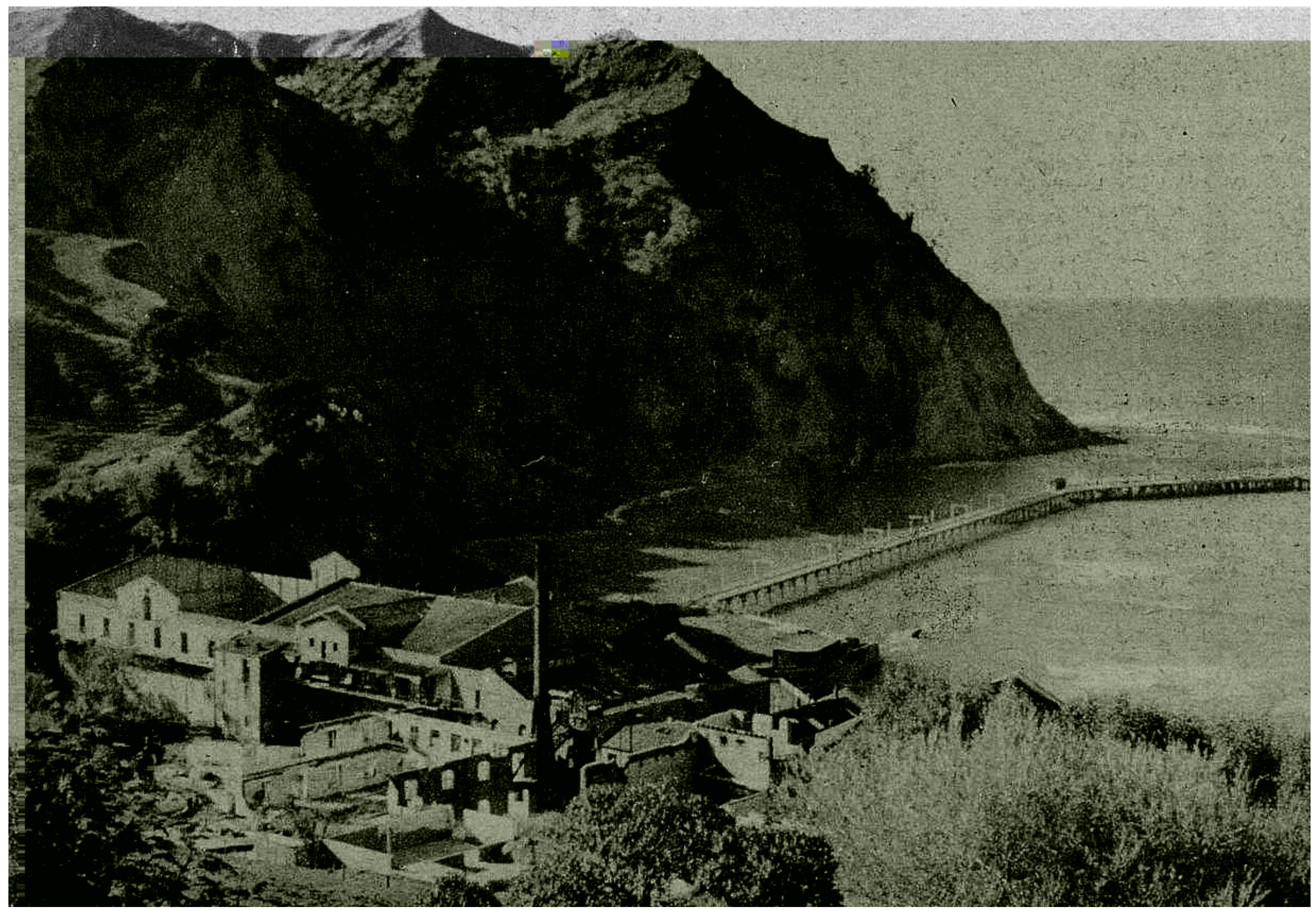




\subsection{Site Location}

\section{North Island}

Tokomaru Bay Freezing Works ruins are located on the East Coast of the North Island.

The East Coast is a geographically isolated region with only three roads connecting the region to the rest of the island. The region has very steep terrain composed of young sedimentary rock with numerous rivers and a relatively high rainfall. The East Coast region is sparsely populated. There are high rates of unemployment in the area due to the lack of jobs available in the region.

Tokomaru Bay is $90 \mathrm{~km}$ north of Gisborne, the region's main centre. Located on the Pacific Coast Highway (state highway 58), Tokomaru Bay is $8 \mathrm{~km}$ long, with a small township at the mouth of the Mangahauini River.

At the north end of Tokomaru Bay is Waima Cove, the former freezing works are located at the end of the road sited around the wharf and other heritage listed buildings that form the Waima Heritage Precinct.
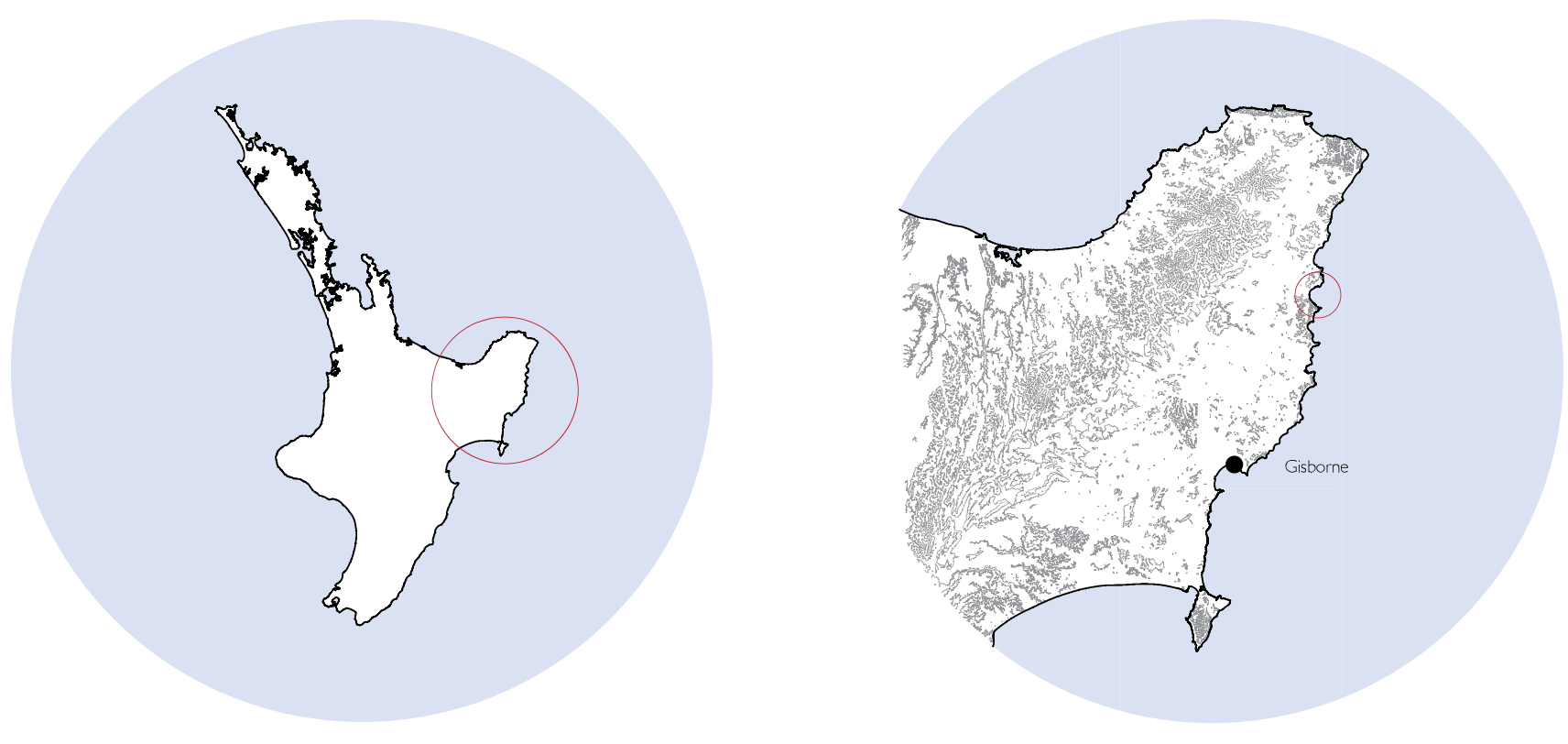
Tokomaru Bay

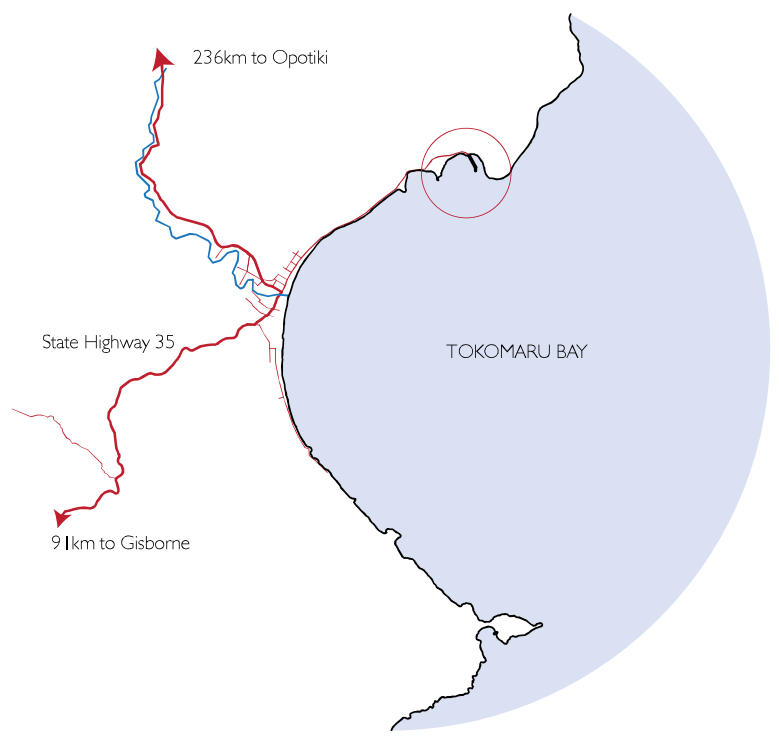

Waima Cove

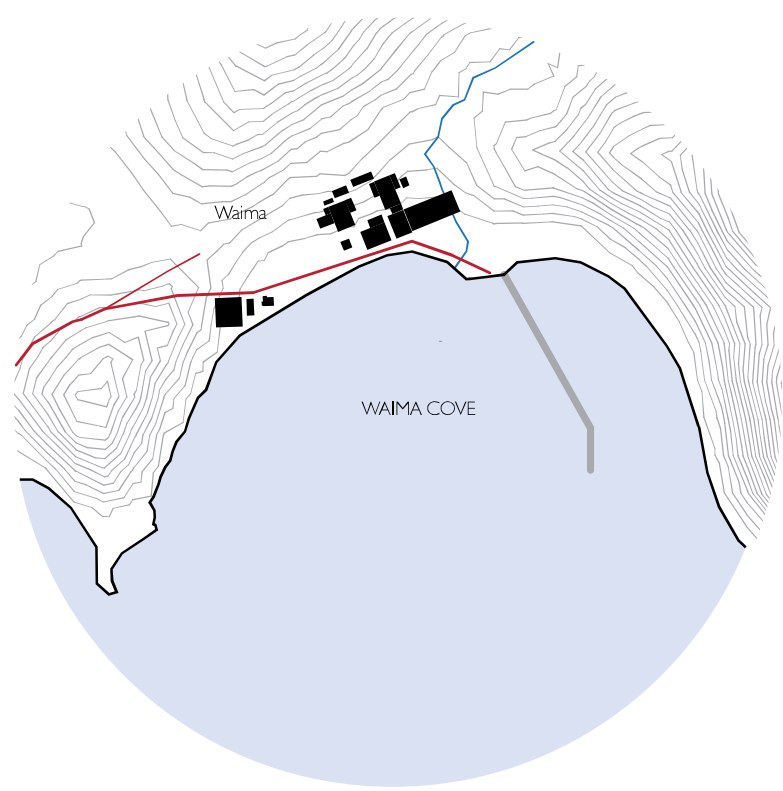

Figure 33 Waima Cove Source: Author's Image 


\subsection{East Coast Region}

The East Coast is split into two areas. Poverty Bay which includes Gisborne and its surrounds, and East Cape which encompasses the top half of the region. The East Cape region is a beautiful and rugged corner of New Zealand, rich in culture and history. Although isolated, residents identify positively with the regions remoteness, embracing the different way of life. $88 \%$ of the East Cape population identified as Māori in the 2013 census (Stats NZ).

Today forestry is the largest industry on the East Coast followed by agriculture. In the second half of the 20th century large areas of hill country were planted with radiata to mitigate severe erosion issues throughout the region.

Farmers are in a constant struggle to maintain land as Mānuka is prolific at regenerating on the East Coast.
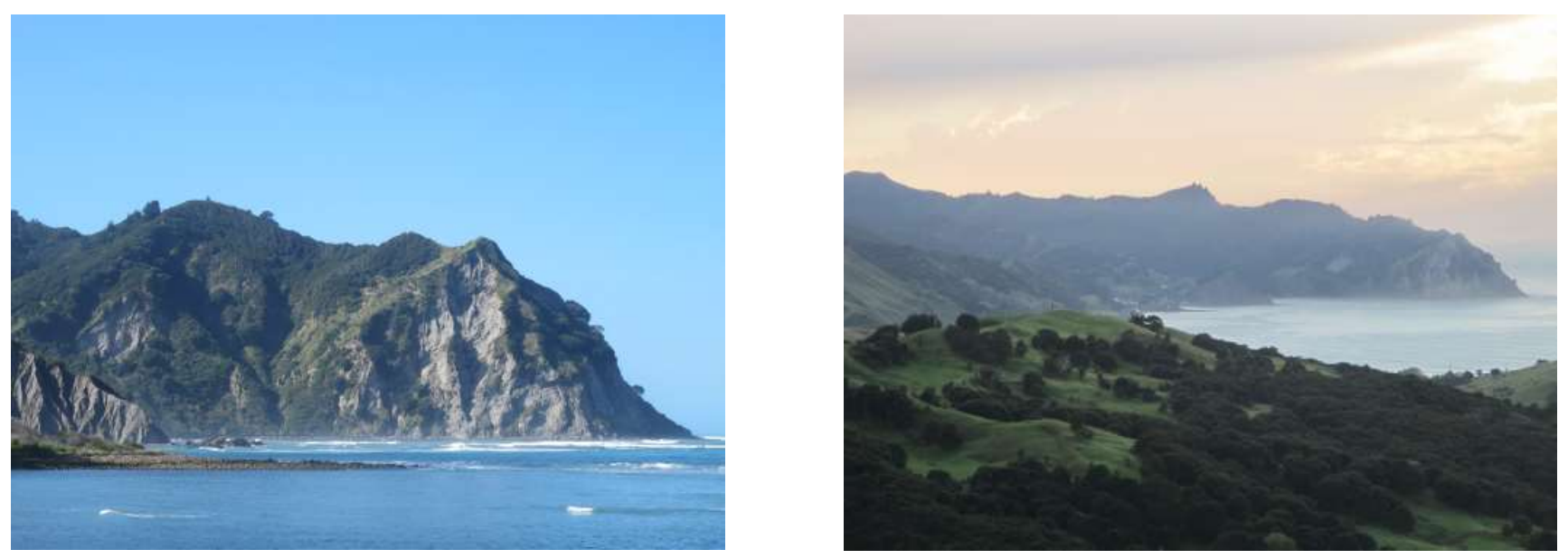

Figure 35 Mānuka bush regenerating on farmland above Tokomaru Bay.
Source: Author's Image 


\subsection{Tokomaru Bay}

The community has a population of 390 , a far cry from the 5000 that Tokomaru Bay during its peak in the 1940's (Stats NZ).

The highs and lows of the frozen meat industry has shaped the towns history, the growth and decline of the town was bonded to the freezing works. Today many houses are abandoned; shops, banks and schools are boarded up or in disrepair. The town sees an influx of local and international visitors traveling the Pacific Coast highway in the summer months and quietens down during winter.
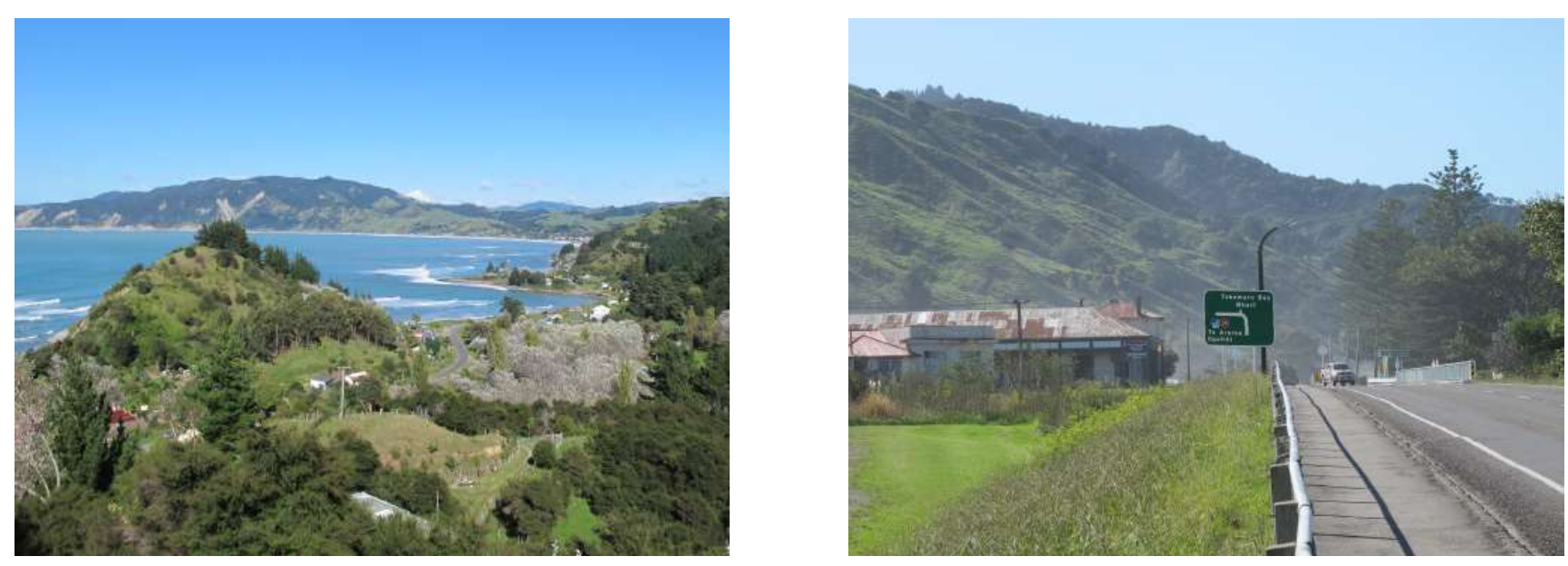


\subsection{Waima Cove Then and Now}

\section{Waima Cove}

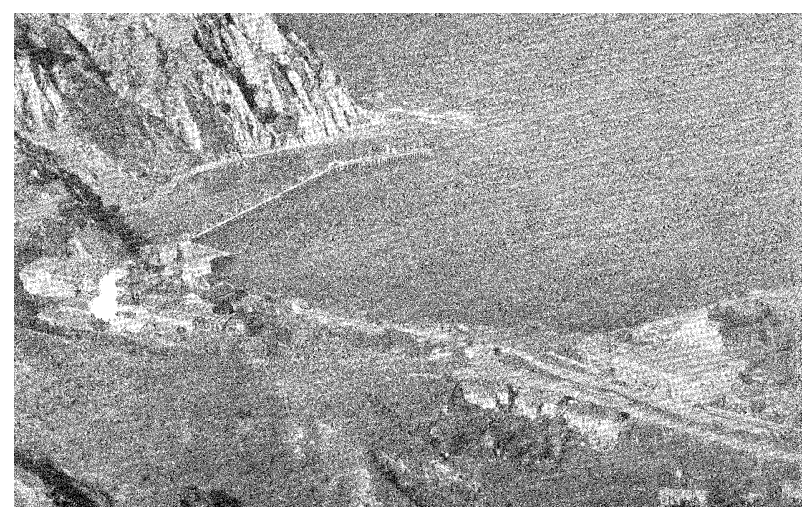

Located at the end of the road, Waima Cove is the most northern part of Tokomaru bay.

Waima Cove was selected as the most ideal location for the freezing works, subsequently many buildings and amenities were located nearby.

"As the imposing brick buildings went up, so too did dozens of houses built for freezing works, shipping company, and harbour board employees" (Gundry, 20).

Figure 38 Tokomaru Bay freezing works at Waima, 1949 Source: Tairawhiti Museum

\section{Freezing Works}

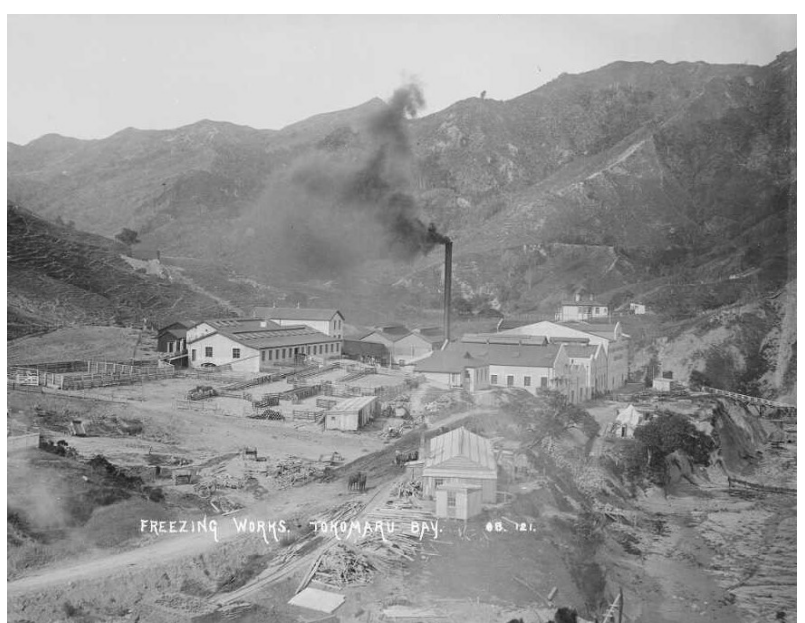

Opened in 1910, the freezing works were "built to last with solid brick construction and concrete floors. One and quarter million bricks were used" (Gundry, 20). The works could handle 2500 sheep and 60 cattle daily and provided hundreds of jobs for the local community. A reinforced concrete extension to the freezing chambers was added in 1917. Facing the ocean, the works are tucked into the hills behind with a stream nearby. The freezing works are a "group of plastered-brick and concrete buildings with timber internal partitions and gabled roofs, between one and three stories high. Several buildings were constructed adjoining each other and formed a continuous façade along the road" (NZHPT).

Figure 39 Overlooking the Tokomaru Sheepfarmers' Freezing Company Ltd works at Waima, Tokomaru Bay. Source: William Price
Wharf

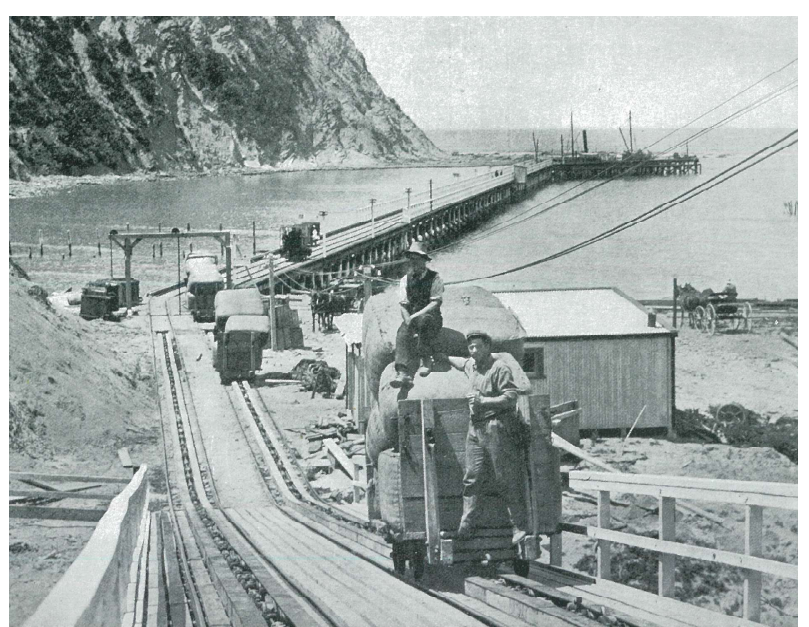

The original wharf was built in 1911, and was 365 metres long. It was replaced in 1940 by a reinforced concrete wharf. The wharf's location provides shelter from the open ocean, as well as accessing the deepest water in the cove.

Figure 40 A steam locomotive and horses were used on this railway to carry wool and meat from the Tokomaru Bay works to the lighters at the end of the wharf. Waima, 1912.

Source: Tairawhiti Museum 


\section{Woolstore}

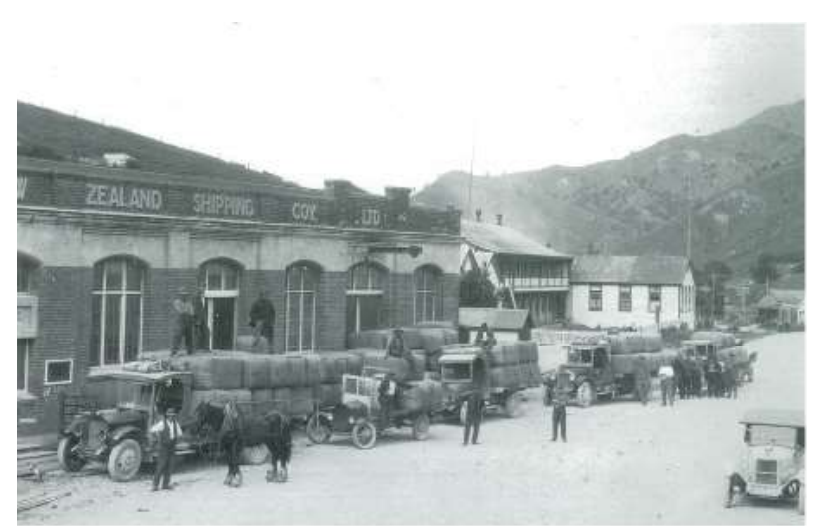

Constructed in 1912, the NZ Shipping Company wool store is a fine example of an U.R.M heritage building.

\section{Horse Stables}

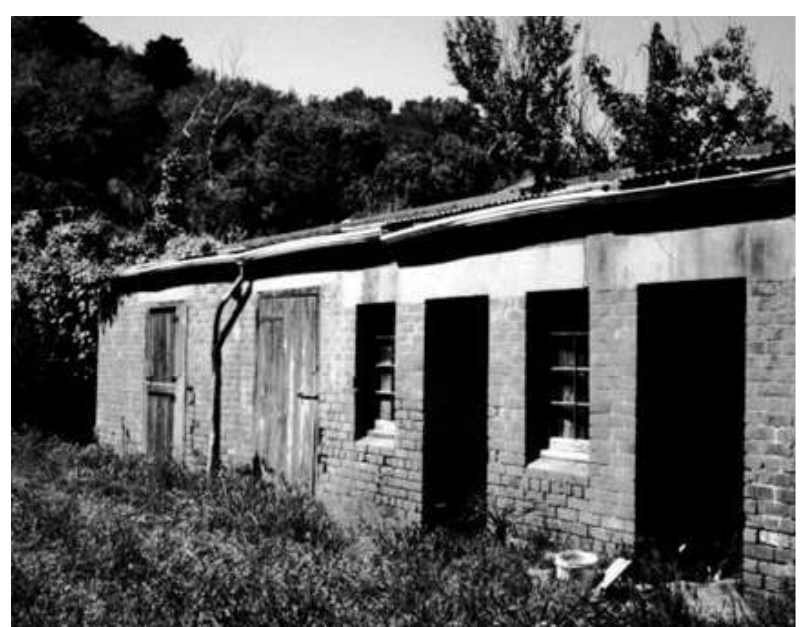

Located next to the wool store, the horse stables were constructed in 1912. Horses were used transporting cargo in the area for a long time due to the regions reliance on shipping and lack of road infrastructure.

\section{Manager's House}

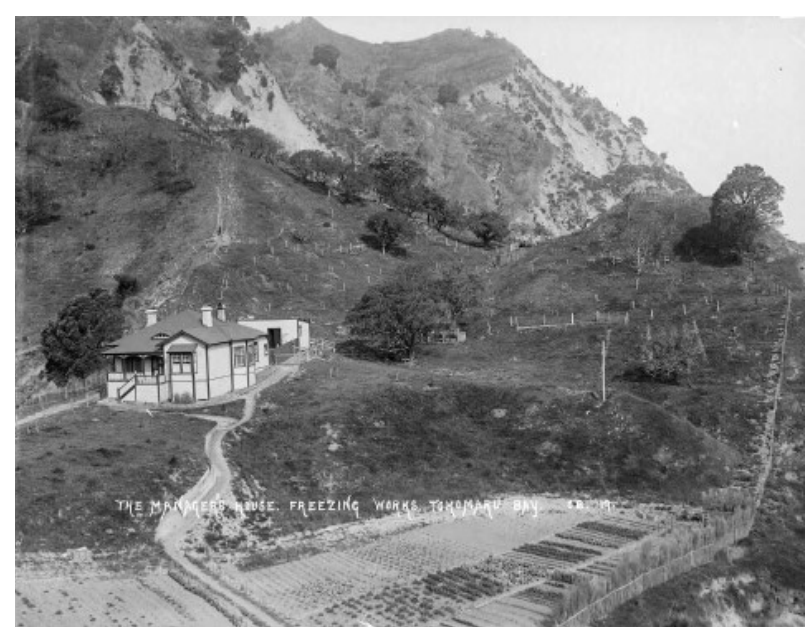

Constructed in 1913 The NZ Shipping Company Manager's house is located in between the freezing works and wool store. The harbourmaster, NZ Shipping Company manager and freezing works manager all had well-appointed houses that looked over Waima Cove.
Figure 41 Trucks delivering wool to Waima in 1926, Barracks and store can be seen behind.

Source: Tairawhiti Museum
Figure 43 The manager's house, Tokomaru Sheepfarmers' Freezing Company Ltd, Waima

Source: Oates Brothers 


\subsection{Waima Cove Then and Now}

\section{Waima Cove}

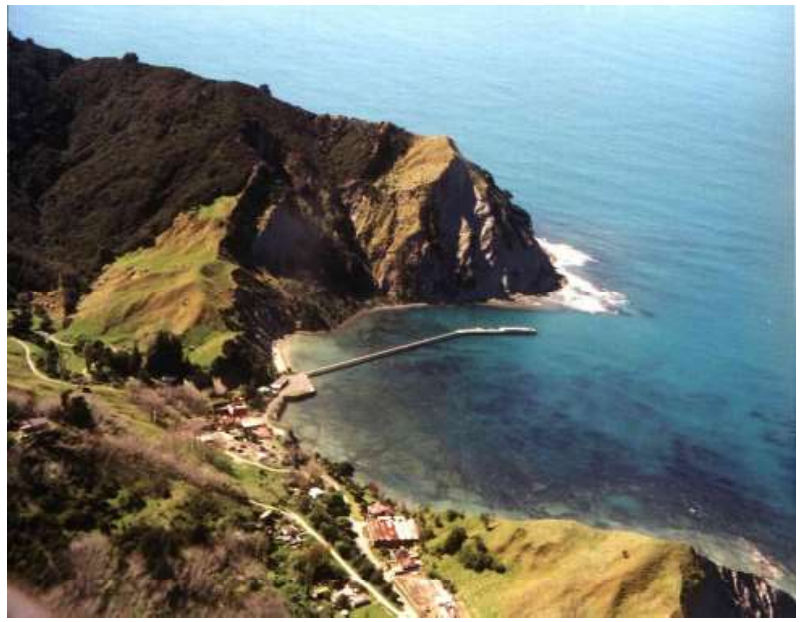

Today Waima Cove offers a glimpse of days gone by. The Waima heritage precinct is made up of 5 interrelated buildings and structures of similar age that are listed as category II historic places: freezing works, wool store, wharf, horse stables, and NZ Shipping Company manager's house. A tramway that was used to transport goods between the wool store, freezing works and wharf can still be seen today.

\section{Freezing Works}

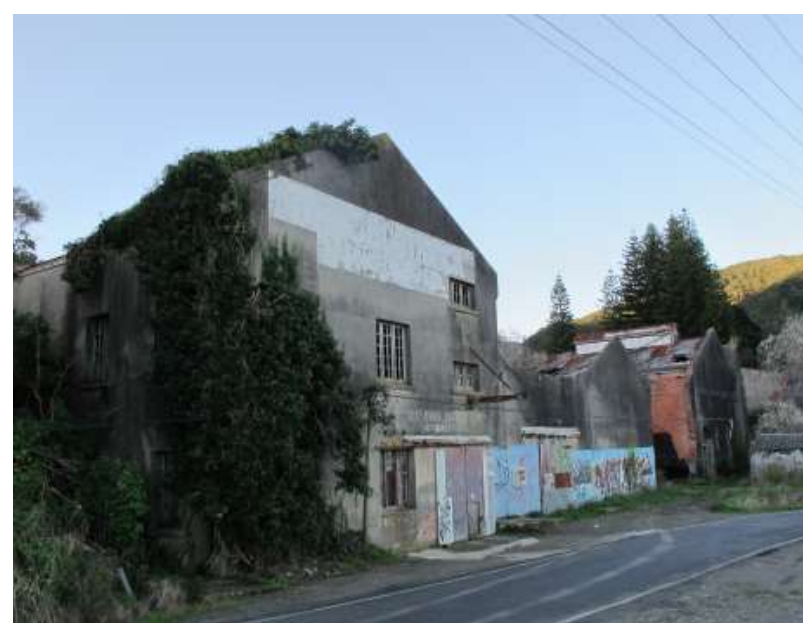

The freezing works closed in 1952 and was stripped of all salvageable material. Large portions of the works demolished in 1954.

What remains of the works is in disrepair and is overgrown.

"The ruins are a tangible reminder of the role that agriculture has played in the development of the Tairawhiti region, and its now-decayed state bears silent witness to the highs and lows of economic growth and decline in provincial and coastal New Zealand" (NZHPT).
Wharf

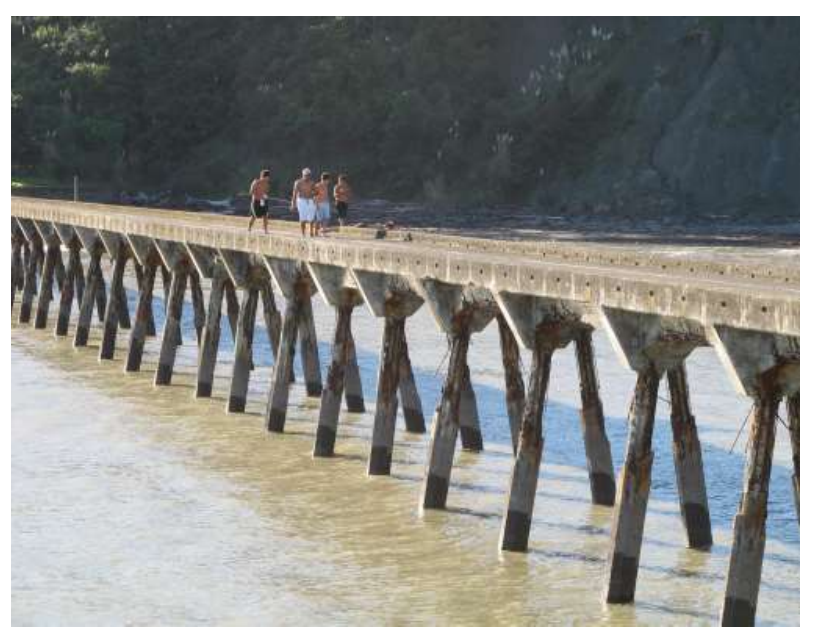

Tokomaru Bay Wharf has historical and social significance as a recognisable remnant of a once thriving industry in Waima (NZHPT).

Salt water has not been kind to the wharfs foundations and today the wharf is officially closed, although one can still walk to the end of the reinforced concrete section at their own risk. Fundraising for the wharf's \$2 million restoration has been underway for a number of years by the local community. 


\section{Woolstore}

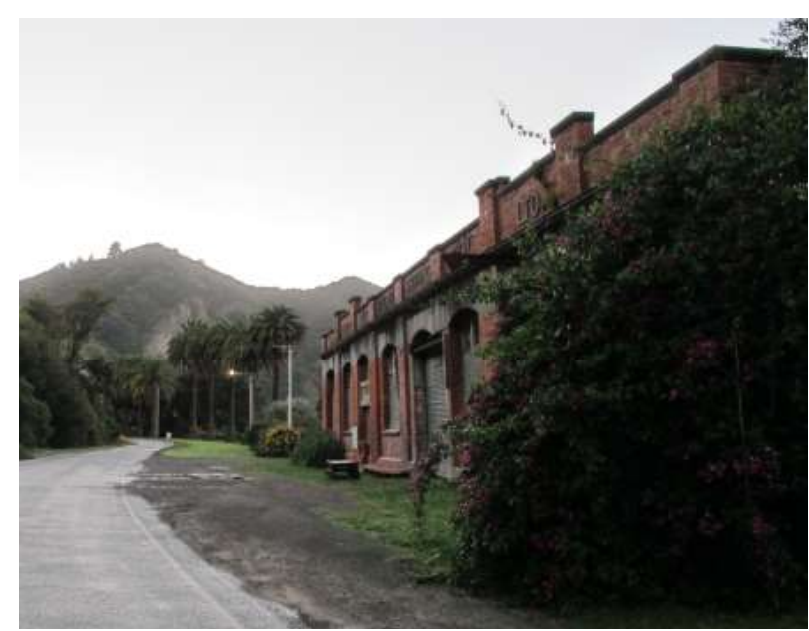

The building was sold by the district council and is now privately owned. The building is currently used for storage by locals and in disrepair with sections of the roof beginning to collapse.
Horse Stables

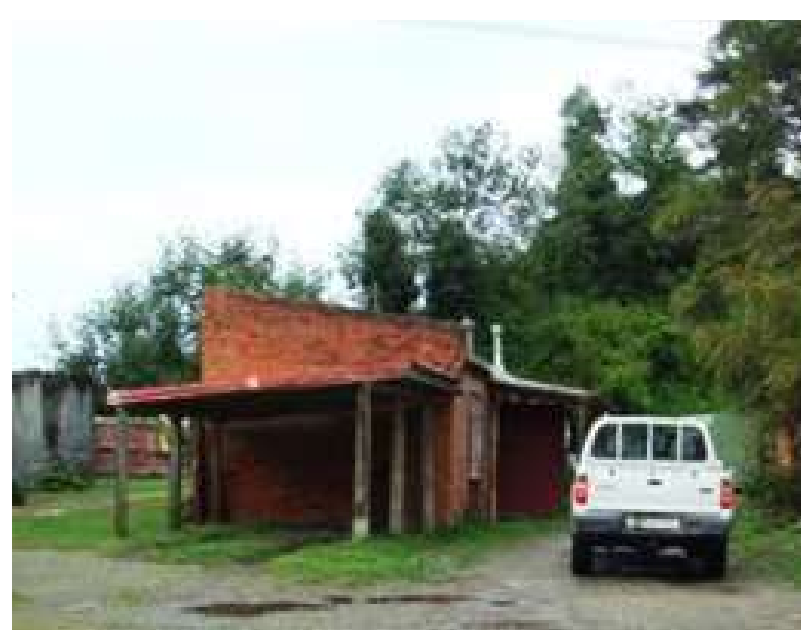

The building was sold with the woolstore to locals who have adapted the stables for living quarters.

\section{Manager's House}

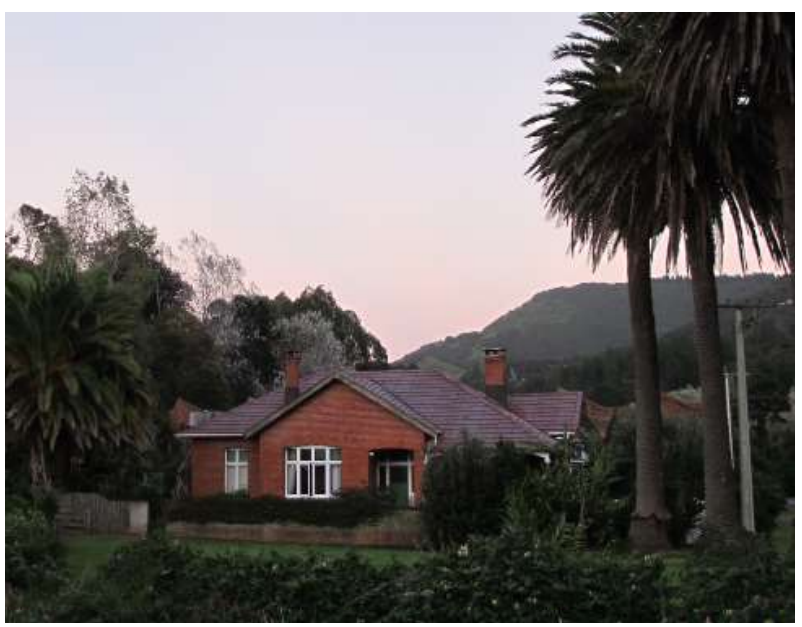

The NZ shipping company managers house is the only one remaining in the area. Overlooking the water, the house is in good condition and is a now a private residence. 


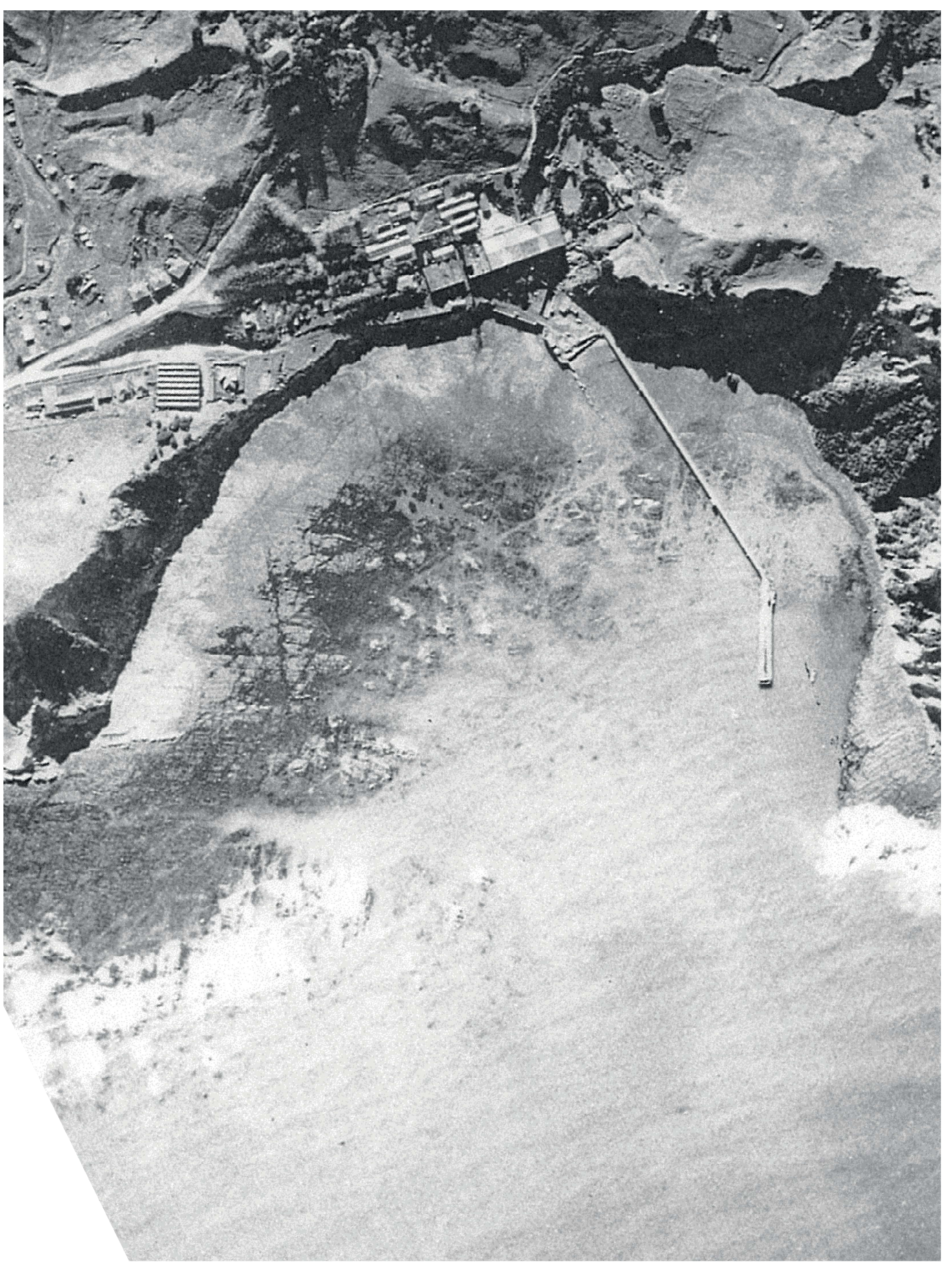




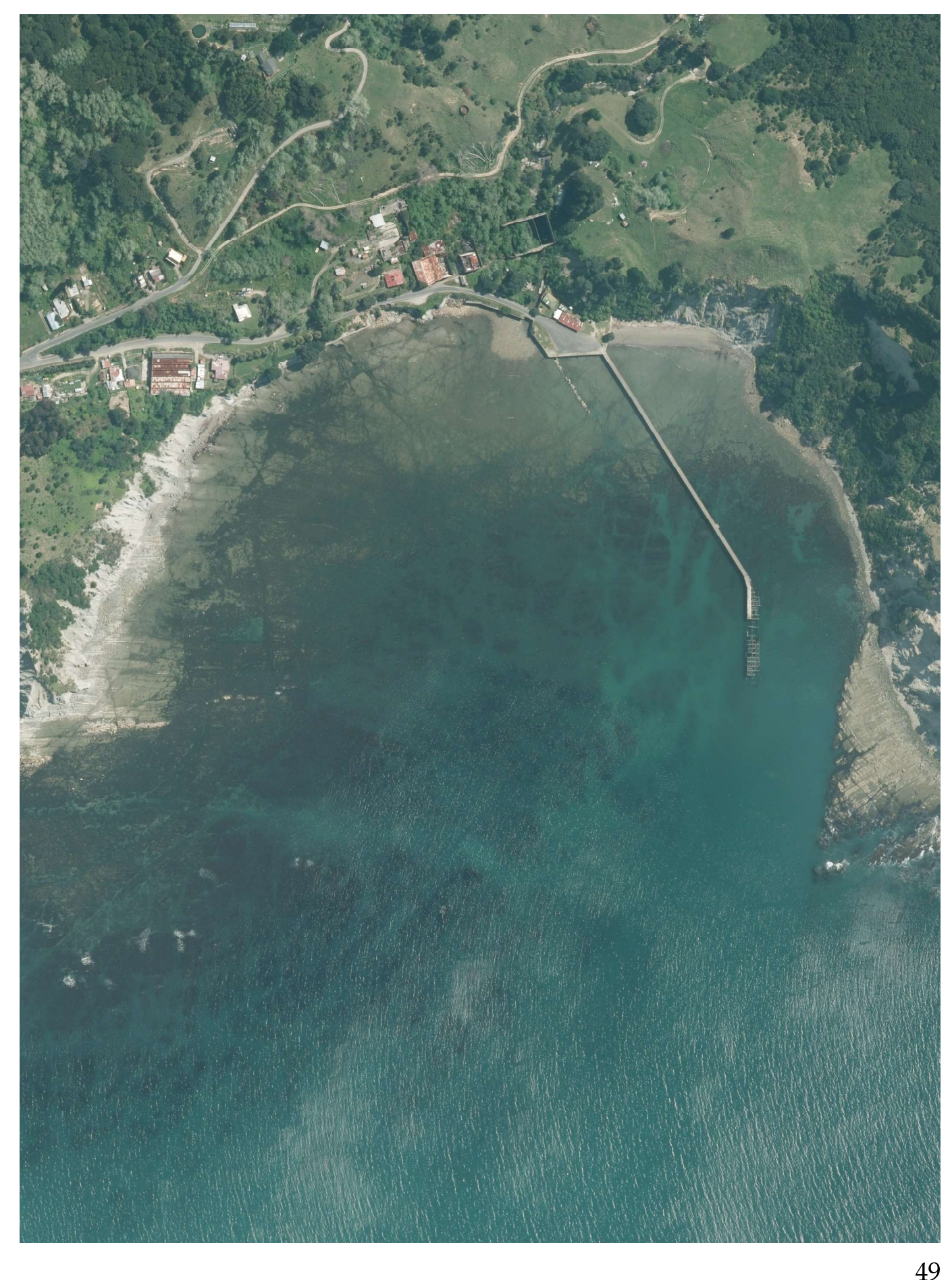




\subsection{History of the Land}

\section{Bush Burning}

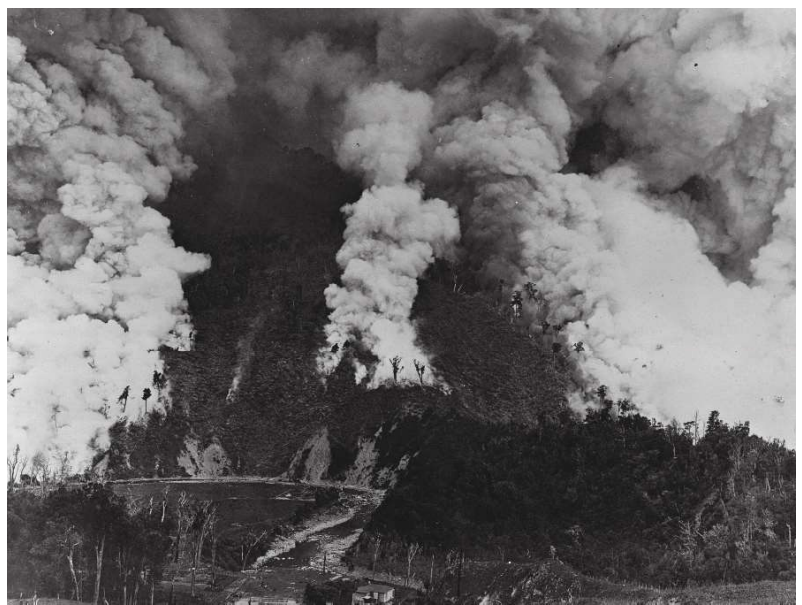

Because of East Coast's isolation and geography, the region remained largely undeveloped as the rest of New Zealand's native timbers were logged. The advent of the freezing works industry promoted more and more marginal land to be cleared as settlers turned to agriculture to make a living. Bush burning was the most efficient method to clear land. Whole parcels of land were cleared, irrespective of the suitability for farming.

\section{Clearing the Land}

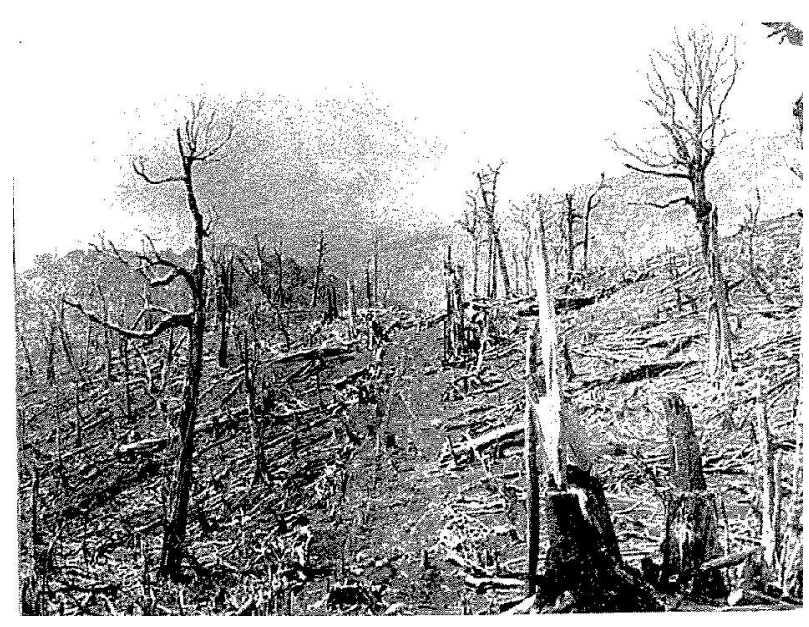

Once the bush was burnt land was cleared and European grasses were sown to establish pastures.

\section{Farm Intensification}

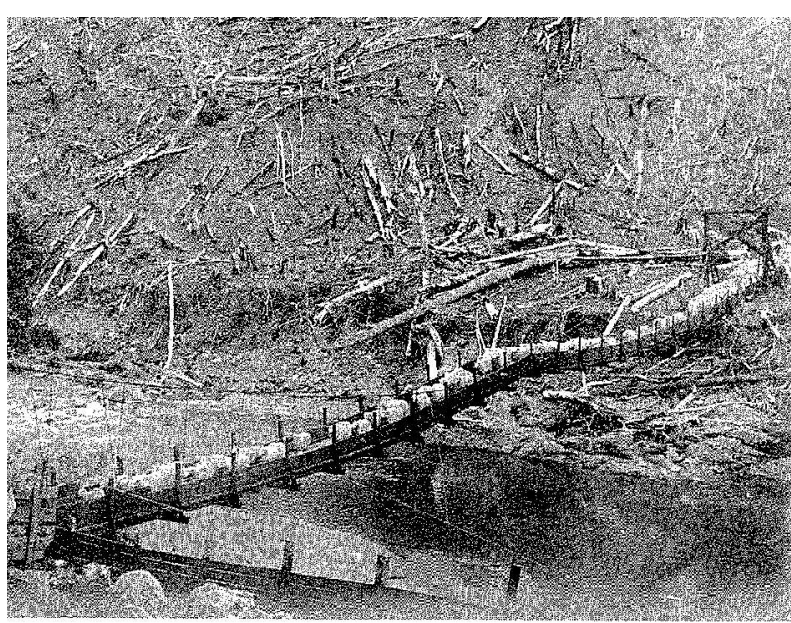

Initially the cleared land was productive due to virgin soils and nutrients from ash. This sparked a boom in sheep and cattle numbers in the district.
Figure 52 The start of a 30,000 acre fire, lit to clear the land of bush, circa 1900s. Puketoro Station, East Coast.

Source: Frederick Hargreaves, Alexander Turnbull Library
Figure 53 Bush Clearing - the first stage in pasture development The ravaged landscape is Mokoiwi Station, East Coast.

Source: Tairawhiti Museum
Figure 54 Sheep crossing the Mata River on Puketoro Station, early 1900's.

Source: Frederick Hargreaves, Alexander Turnbull Library 


\section{Erosion of Marginal Land}

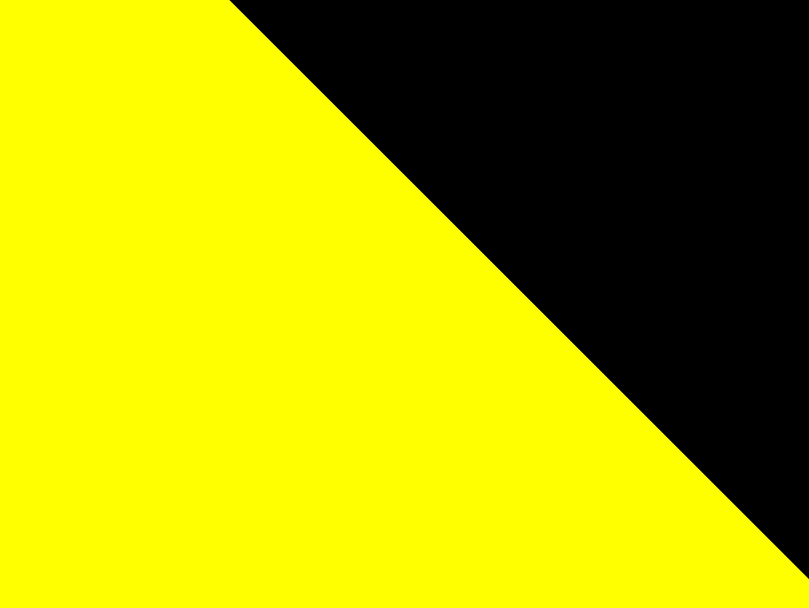

Farm intensification on marginal hill country meant that the land was very unstable. The East Cape's soft soils combined with high rainfall resulted in major issues with erosion across the region. This led to the silting of low lying areas, resulting in flooding to lower farms and townships.

\section{Clear-fell forestry}

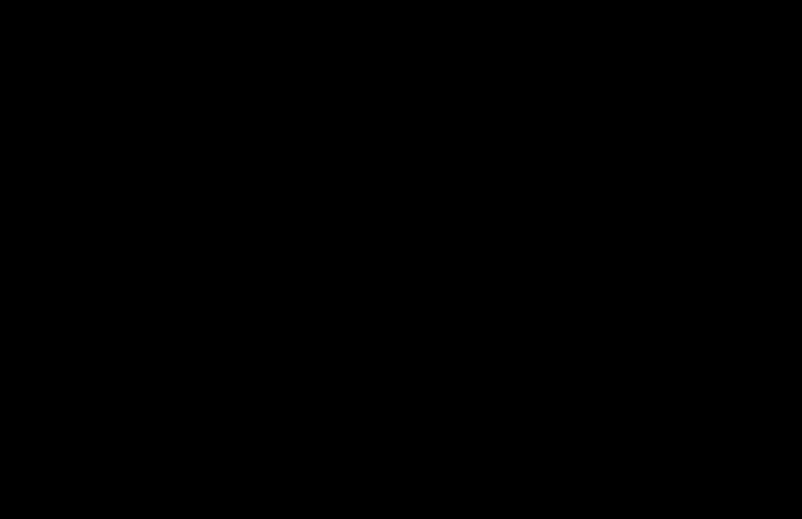

The second half of the 20th century saw the rise of the forestry, radiata plantations were a quick solution to the region's erosion issues. The clear-fell harvesting of forests planted on thin soiled, steep farmland has brought erosion back into sharp focus. With more forests on sensitive sites yet to be harvested, the sustainability of clear-fell harvesting on this type of land remain

\section{Regeneration}
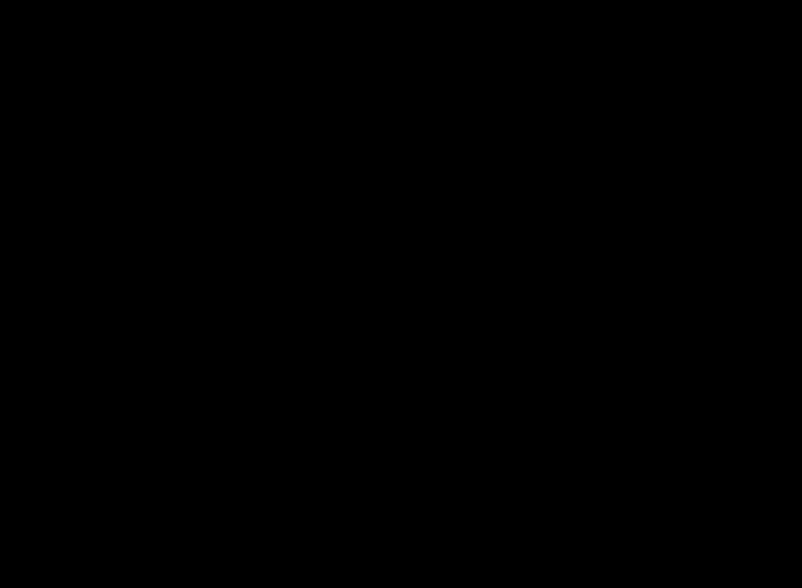


\subsection{East Coast Freezing Works Industry}

\subsubsection{Regional History}

While the East Coast will always be physically isolated from the rest of the country, the introduction of freezing works negated the regions isolation, which led to major agricultural intensification. This brought relief to the region and provided new opportunity and development for the region. "In Poverty Bay the introduction of freezing works must also have seemed like the missing link to economic prosperity" (Smith 183).

At its peak, in the early 20th century, there were five freezing works operating in the East Coast. Taruheru and Kaiti in Gisborne, Tokomaru Bay and Hicks Bay to the north, and Waipaoa inland (Wairoa works, shown on the map, considered part of Hawke's Bay). However, this activity was short-lived and by the mid1950s there was only one works in the region. "Sadly, Gisborne's economic jigsaw was never to be satisfactorily pieced together. Much of the rapidly cleared land proved highly vulnerable to the ravages of nature" (Smith 183). All the regions topsoil was washed out to sea, which led to a decrease in the number of stock the land could carry, and ultimately freezing works were forced to close.

Analysis of the five East Coast freezing works gives context to the Tokomaru Bay site by comparing what is typical or unique about the structures and what the significance of places are.

\subsubsection{Regional Analysis}

- Freezing works industry predates internal road and rail infrastructure in the region. Animals were driven to the freezing works by drovers.

- Works are typically located near the coast to efficiently access overseas export shipping (exception is Waipaoa, which was built later and had access to the coast via rail).

- Works are adequately spaced apart(roughly $100 \mathrm{~km}$ ) from their nearest neighbour to allow large catchments for stock. Exception of Kaiti, Taruheru and Waipaoa works, eventually this led to unsustainable price wars.

- All works rurally located (except Kaiti in Gisborne).

- Works constructed adjacent to existing townships to allow access to workers/ labour.

- While much of this heritage has already been lost, each freezing works has had a different fate depending on its location. The two works located in urban centers, Taruheru and Kaiti, have been demolished to make way for new uses. The rurally located works have remained in ruins as there is less demand for land.

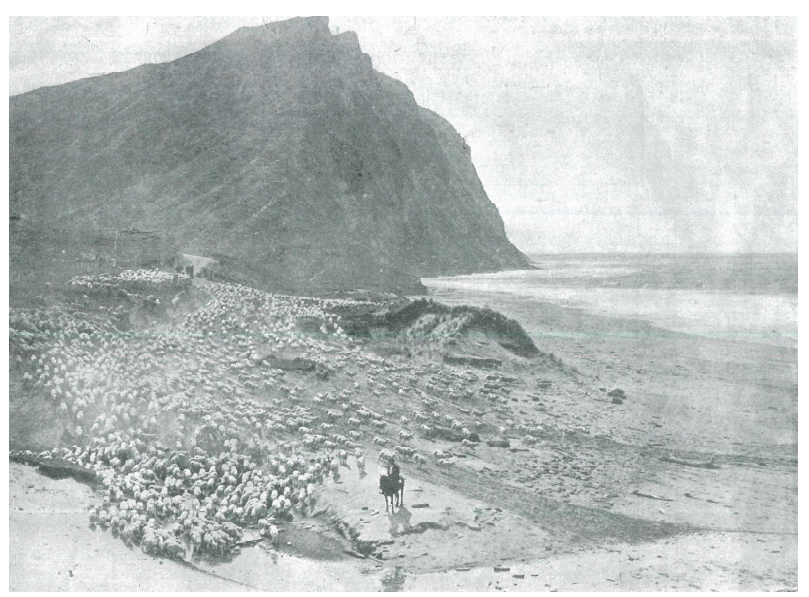

Figure 58 Driving a mob of sheep at Waihau Beach. Source: Tairawhiti Museum 


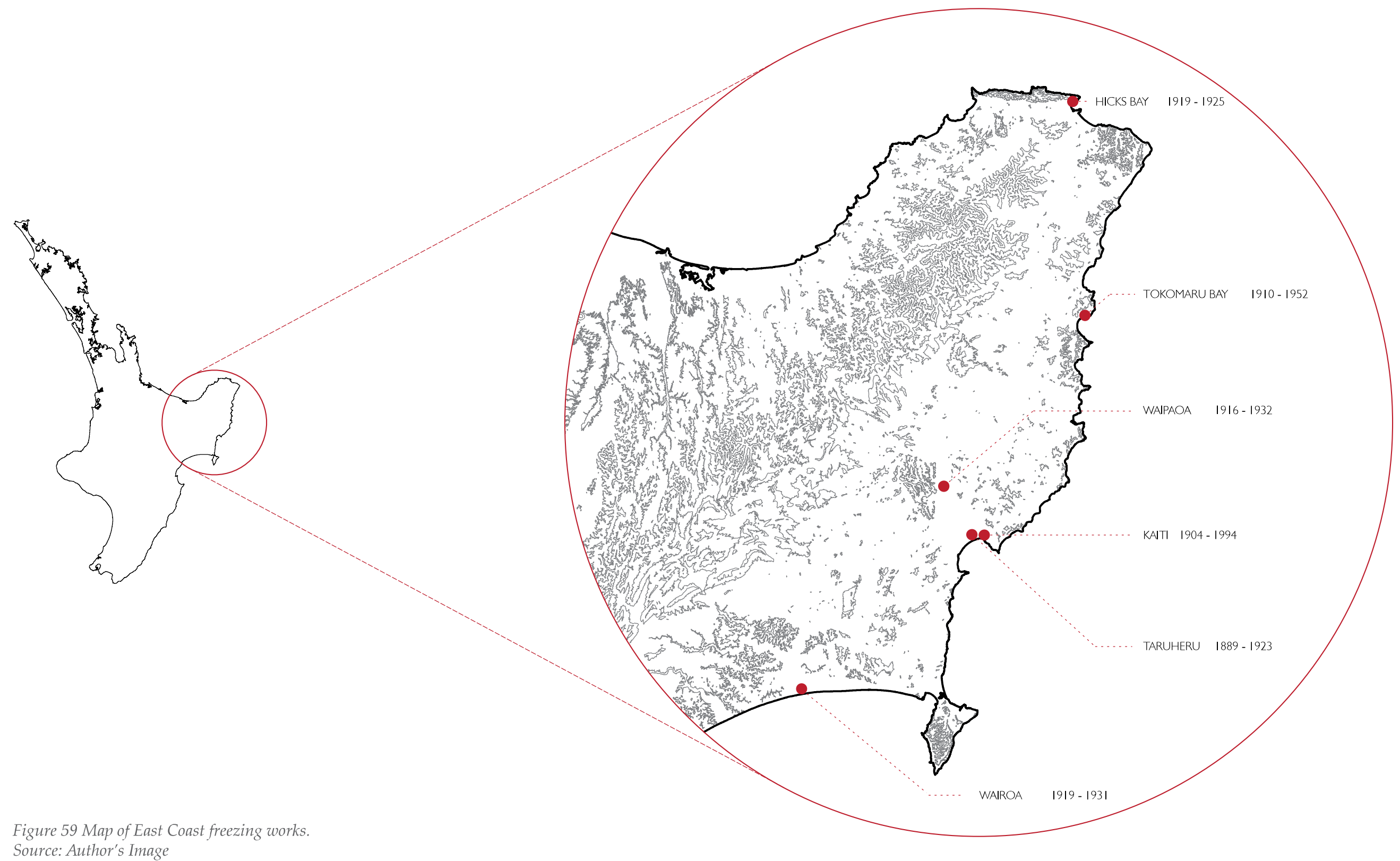




\subsection{East Coast Freezing Works Industry}

\subsubsection{Site Specific Analysis}

- Any timber remains are non-existent either through demolition, fire or being salvaged for reuse after freezing works closed.

- U.R.M structure remaining will require significant strengthening to avoid collapse. [design guideline $2 b$ ]

- Reinforced concrete ruins are intact and generally of sound structure.

- Construction material/method of each freezing works depends on the building technology and availability of construction materials (e.g. early works from built form timber, later works and additions built from reinforced concrete).

- Each freezing works is unique in their individual design due to variances such as site context, technological development, material development and changes in production methods.

\section{Taruheru 1889-1923}

Timber construction.

$100 \%$ demolished, foundation of smoke stack with plaque all that remains. Land subdivided and used for housing/ public reserve.

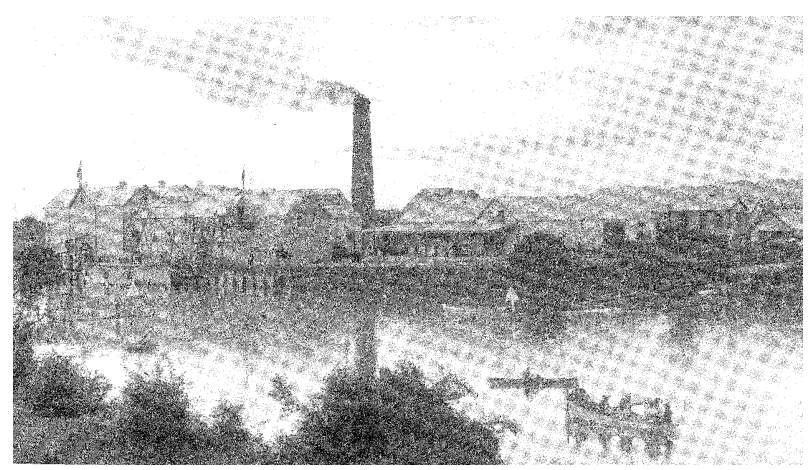

Figure 60 The birthplace of the districts freezing industry. Nelson Brothers' Taruheru Freezing Works, 1891.

Source: Tairawhiti Museum

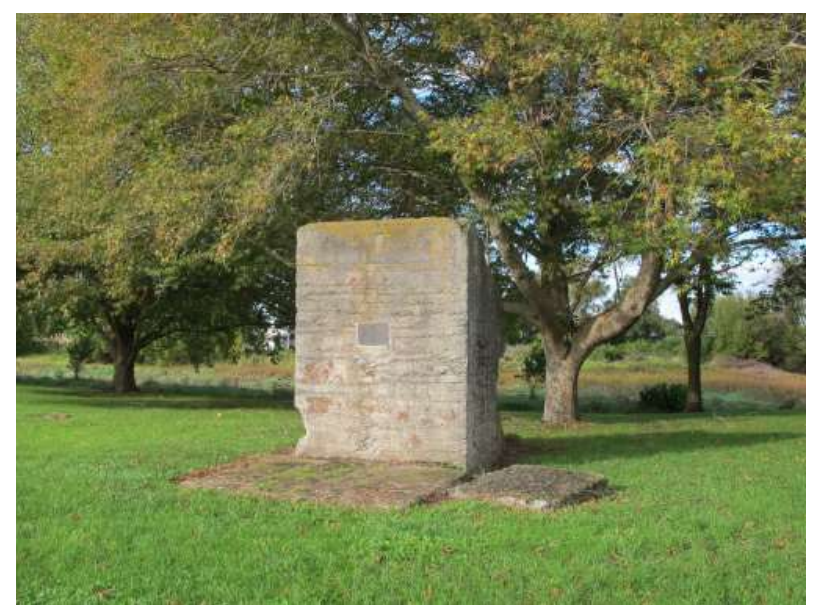

Figure 62 Footing form the base of the smoke stack is all that remains of Taruheru works.

Source: Author's Image

\section{Kaiti 1904-1994}

U.R.M construction.

95\% demolished, one remaining building converted to restaurant, rest of site is used for bulk storage of logs for export.

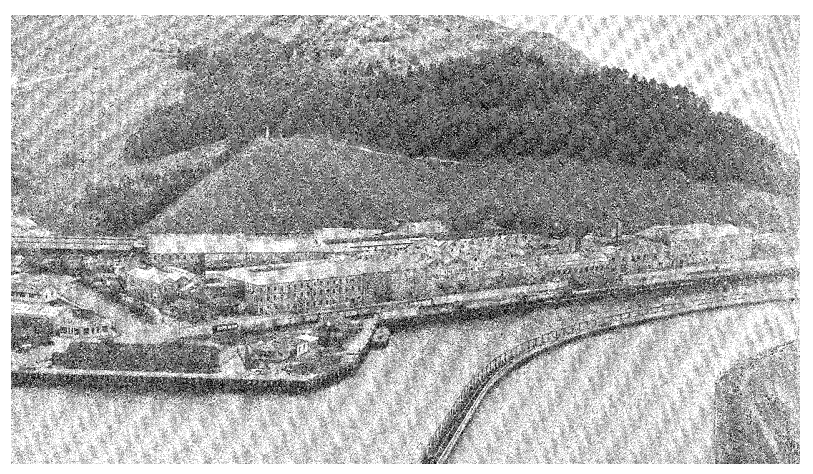

Figure 61 An aerial view of the sprawling Kaiti works, circa 1940. The freezing workers monument is visible on the hill. Source: Tairawhiti Museum

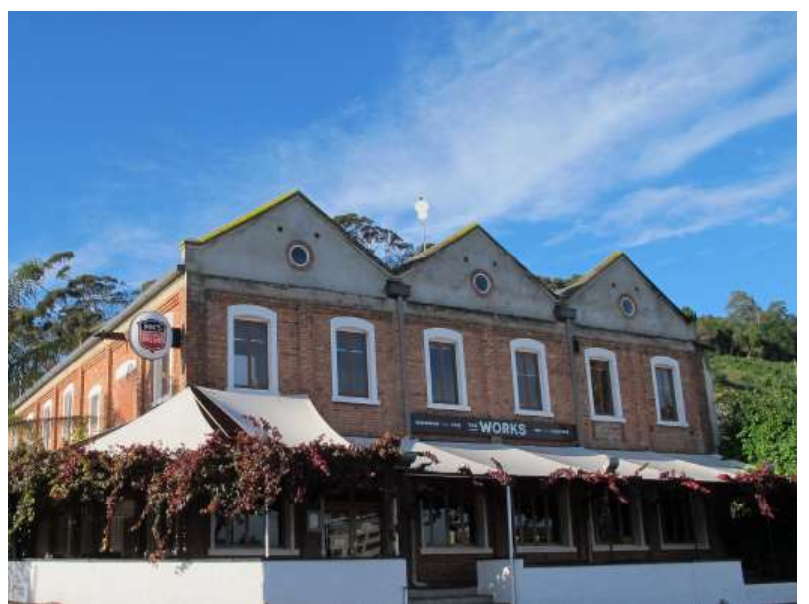

Figure 63 Former Kaiti works converted to a restaurant. Source: Author's Image 


\section{Tokomaru Bay}

1910-1952

U.R.M construction with reinforced concrete extension. 50\% demolished, $50 \%$ ruins and overgrown. Dilapidated and overgrown ruins, one usable remaining building used for storage.

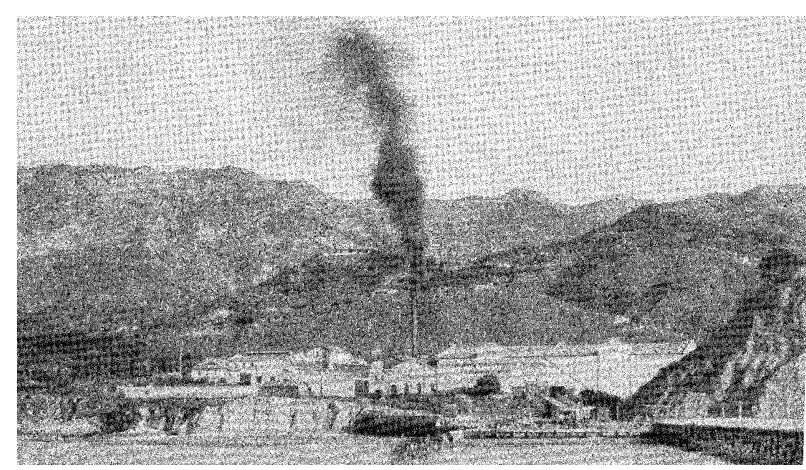

Figure 64 Backed by steep hills, the Tokomaru Bay Freezing Works at Waima commanded what is arguably the most spectacular setting for a freezing works in New Zealand. Source: Tairawhiti Museum

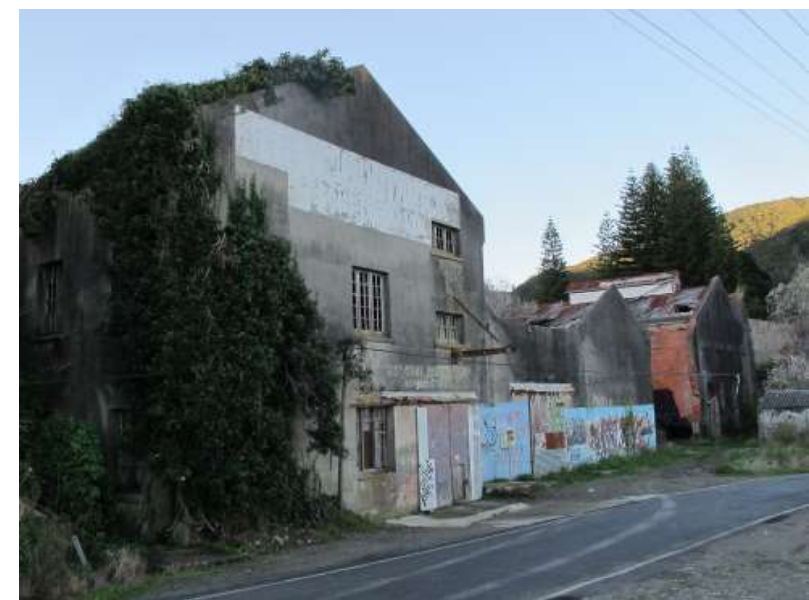

Figure 67 Tokomaru Bay Freezing Works sit dormant. Source: Author's Image

\section{Waipaoa 1916-1932}

Reinforced concrete construction.

$100 \%$ ruins, with only the concrete structure remaining in the middle of a paddock.

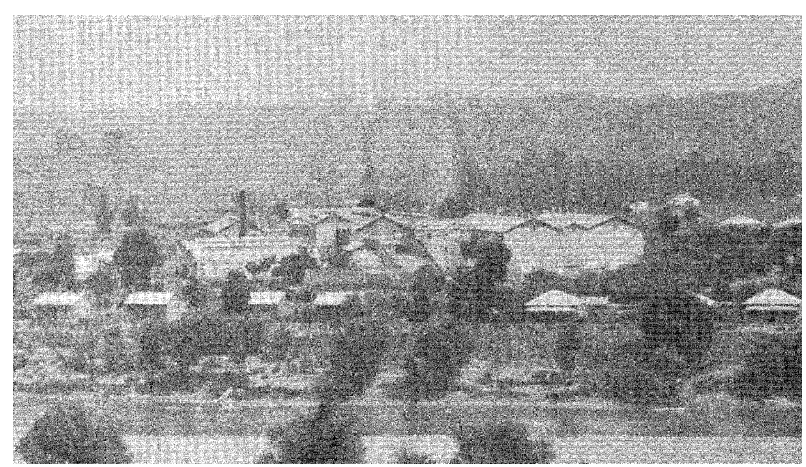

Figure 65 The Waipaoa works was the hub of a whole community complete with workers' cottages, general stores, butchery, barber's shop, blacksmith and a library, circa 1920.

Source: Tairawhiti Museum

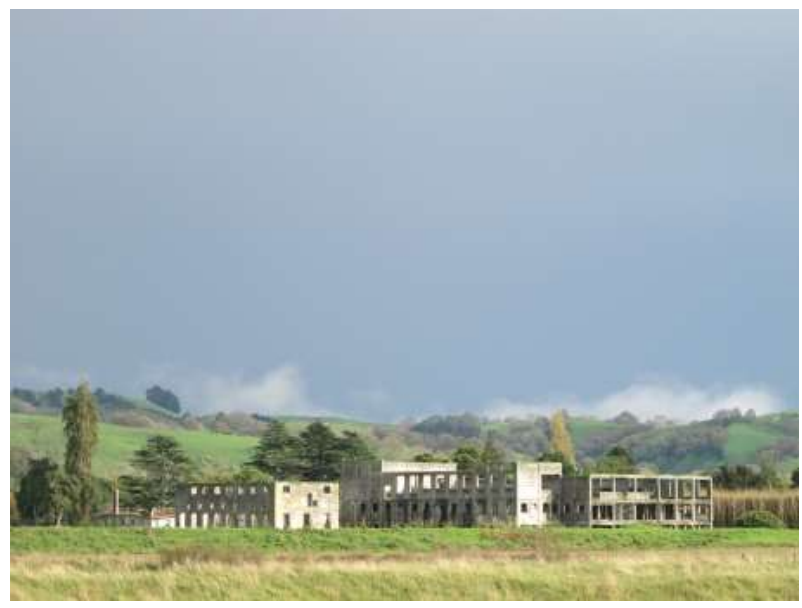

Figure 68 Concrete structure remains of the Waipaoa Freezing Works dominates the landscape.

Source: Author's Image

\section{Hicks Bay 1919-1925}

Reinforced concrete construction.

$50 \%$ demolished, $50 \%$ ruins, concrete structure remains, privately owned and converted into a dwelling.

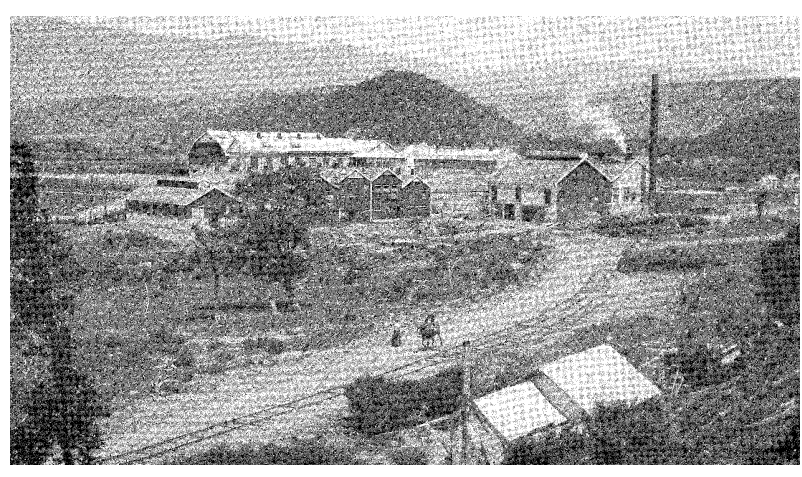

Figure 66 Hicks Bay works in operation, early 1920s. Source: Tairawhiti Museum

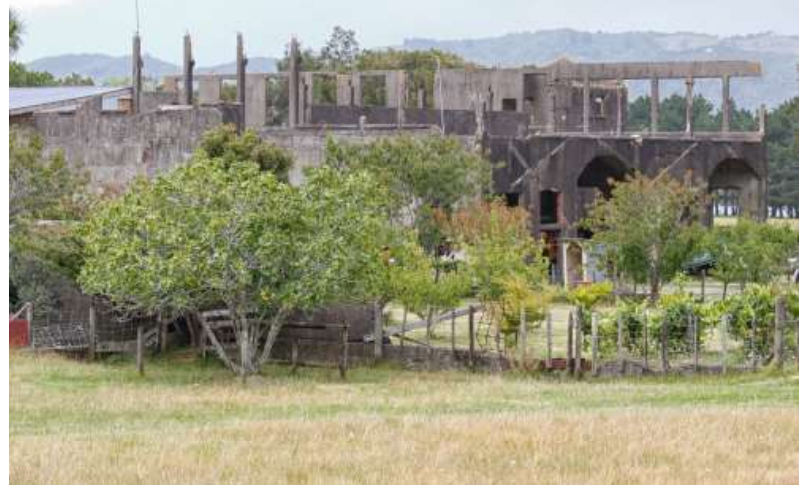

Figure 69 Remains of the Hicks Bay works.

Source: Hayley Grace 


\subsection{East Coast Freezing Works Industry}

\subsubsection{Comparative Analysis}

- Freezing works complexes generally split into 5 main areas: slaughter house, fellmongery, boiling down works, freezing chambers, with centrally located boiler/ pump/engine rooms. Surrounding these main areas are ancillary buildings, which are smaller detached structures located in proximity to their relevant area.

- As industrial buildings, freezing works are designed to be as efficient as possible with minimal aesthetic input.

- Freezing works are typical industrial buildings that provide large open plan internal spaces with internal walls and floors constructed from timber.

- Generally freezing works have rectilinear layout with a strong orthogonal grid (this is more evident in masonry and concrete structures).

- All works have access to fresh water.

- Works have a direct connection to the coast (exception Waipaoa located inland, rail).

- Site plans dictated by geography and spatial requirements, no evidence that north/south orientation is a priority.

- Size of building footprints dictated by building materials used and programme requirements of each space.

- Freezing works in direct connection with water have an obvious frontage and are more compact in their design (Taruheru, Kaiti, Tokomaru Bay). Freezing works set back from water have less spatial constraints, and master plans are more spread out (Waipaoa, Hicks Bay).

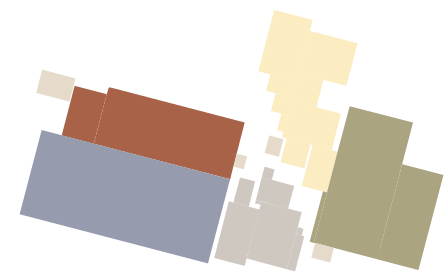

Slaughterhouse

Fellmongery
Tallow and Manure Works

Tallow and Man
Freezing Cham

Freezing Chamber
Engine, Pump, Boiler Rooms
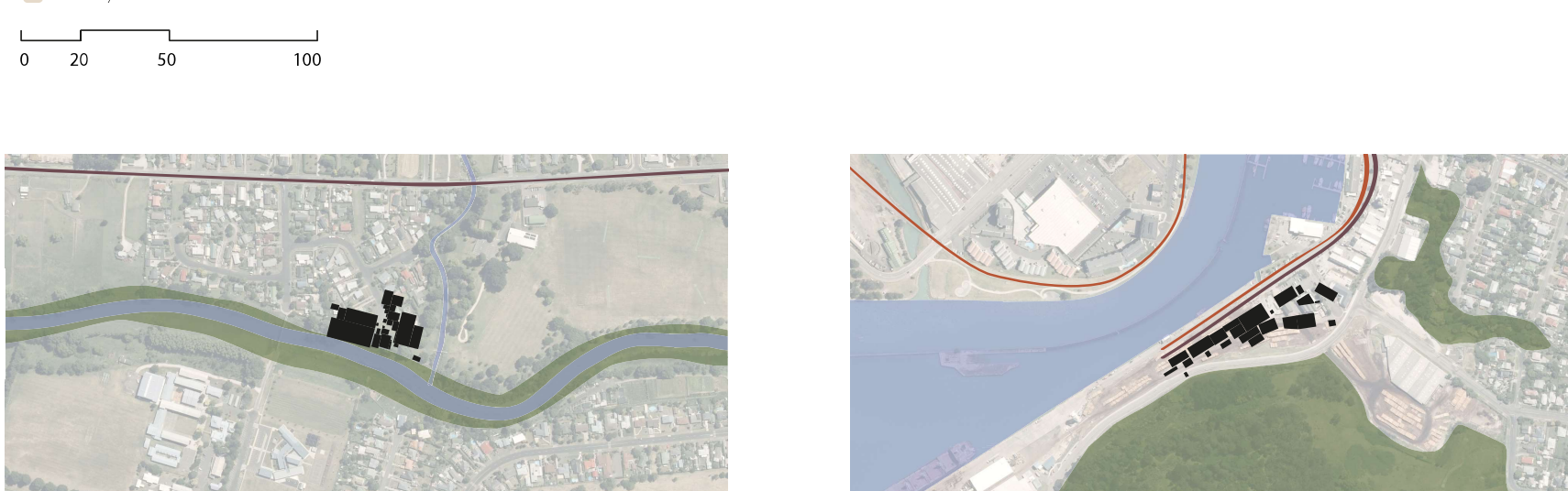

Waterway
Rad
Tramway / Rail connection

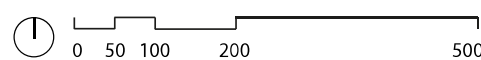

Figure 71 Site Plan and Building Footprint of Kaiti. Source: Author's Image 


\section{Tokomaru Bay 1910-1952}
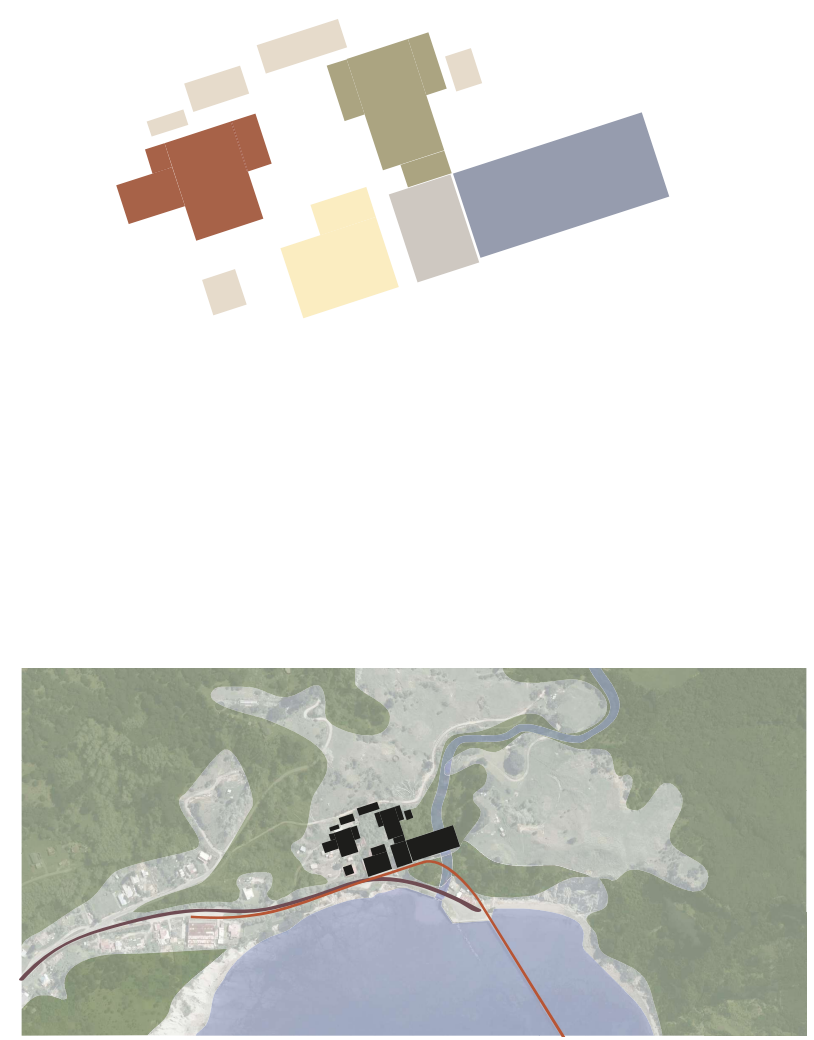

Figure 72 Site Plan and Building Footprint of Tokomaru Bay. Source: Author's Image

\section{Waipaoa 1916-1932}
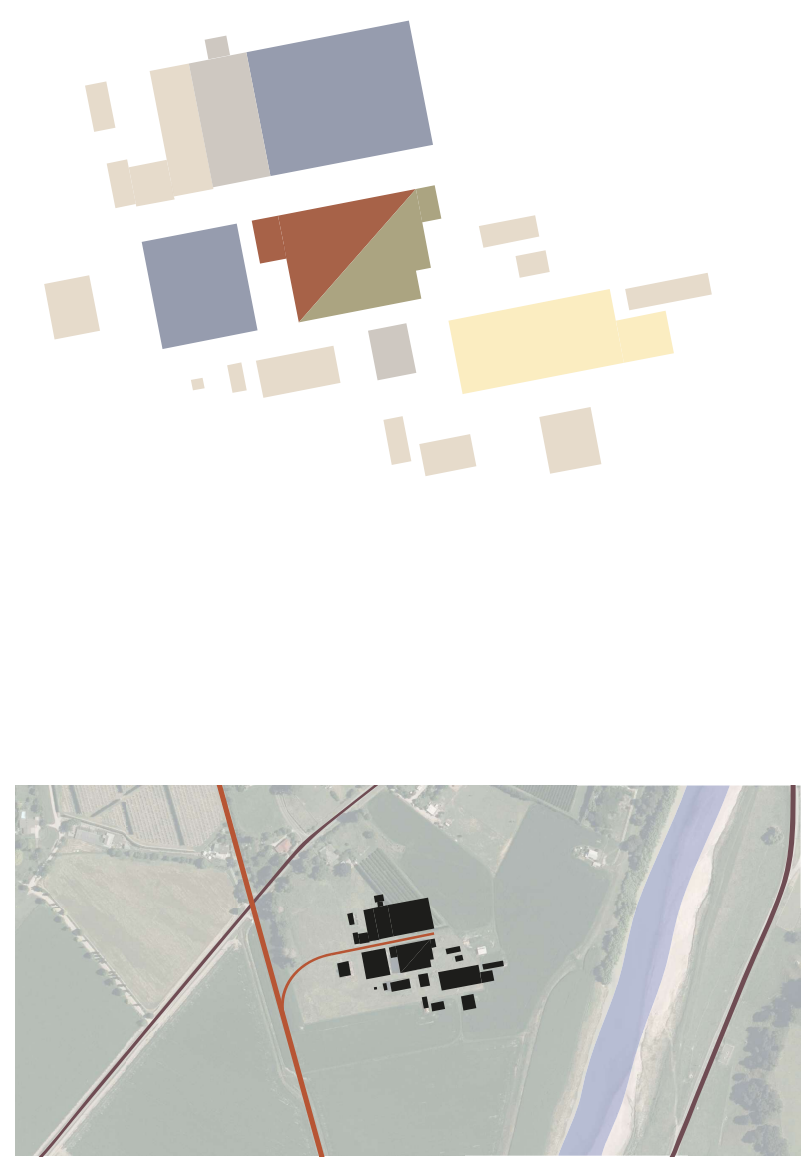

Figure 73 Site Plan and Building Footprint of Waipaoa. Source: Author's Image

\section{Hicks Bay $\quad$ 1919-1925}
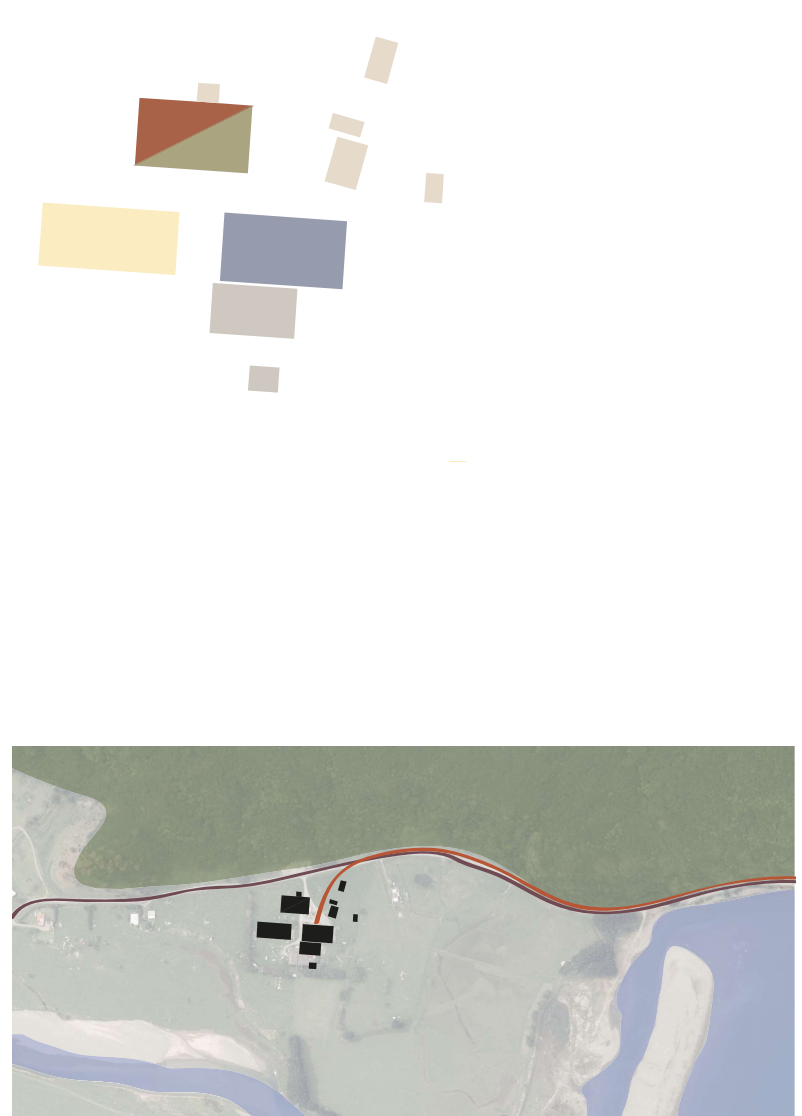

Figure 74 Site Plan and Building Footprint of Hicks Bay. Source: Author's Image 


\subsection{Tokomaru Bay Freezing Works Ruins}

65 years after their closure, the freezing works buildings are in various states of disrepair.

The slaughterhouse has been demolished with only concrete footprints remaining. The manure and tallow works, and the engine rooms are the most intact buildings. Although their roofs are collapsing, the walls are still standing. The freezing chambers are the most overgrown areas of the complex, with the impressive reinforced concrete extension, built over the stream, standing tall above the trees.

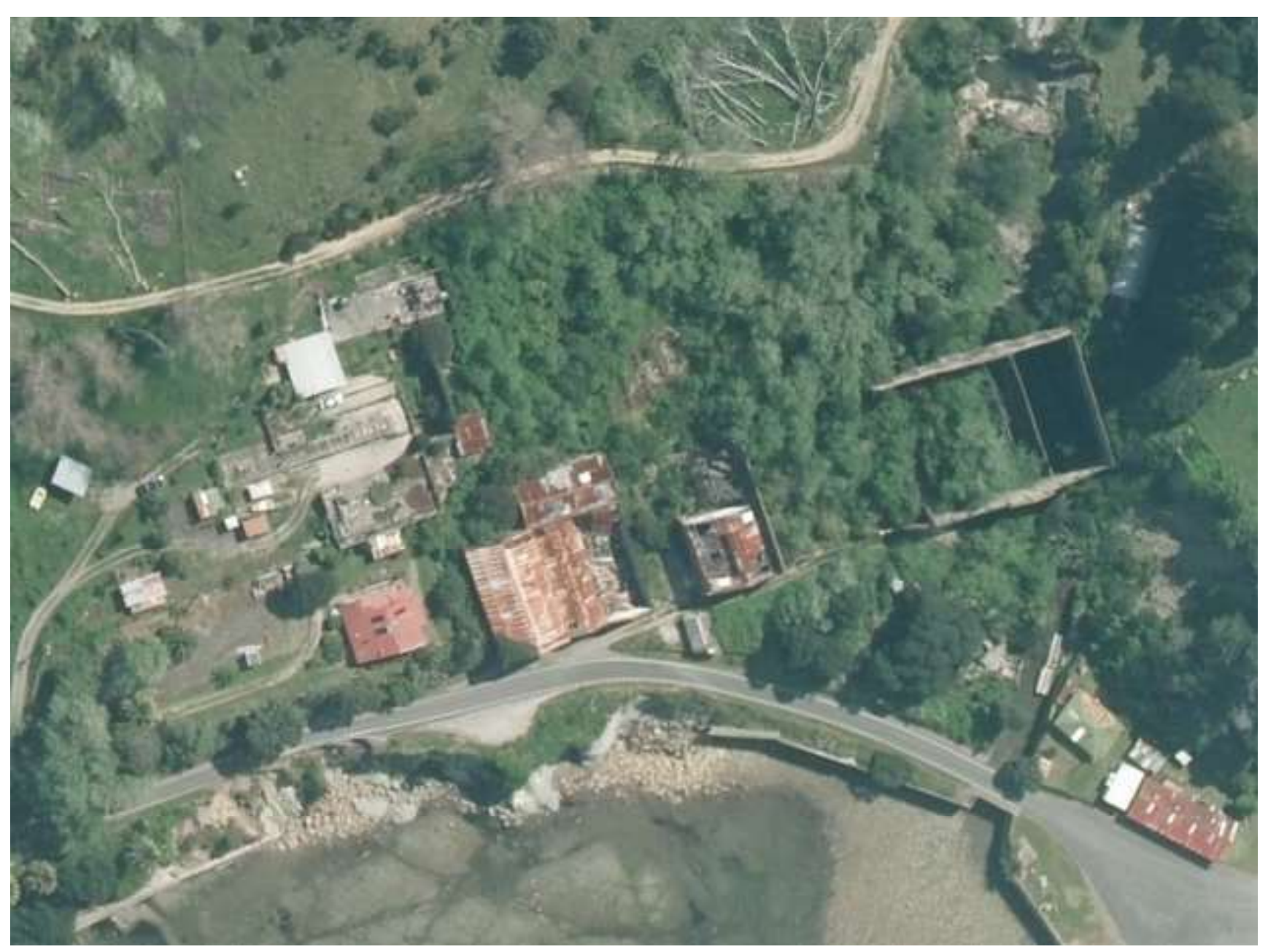

Figure 75 Aerial of Tokomaru bay Freezing Works ruins 2017. 

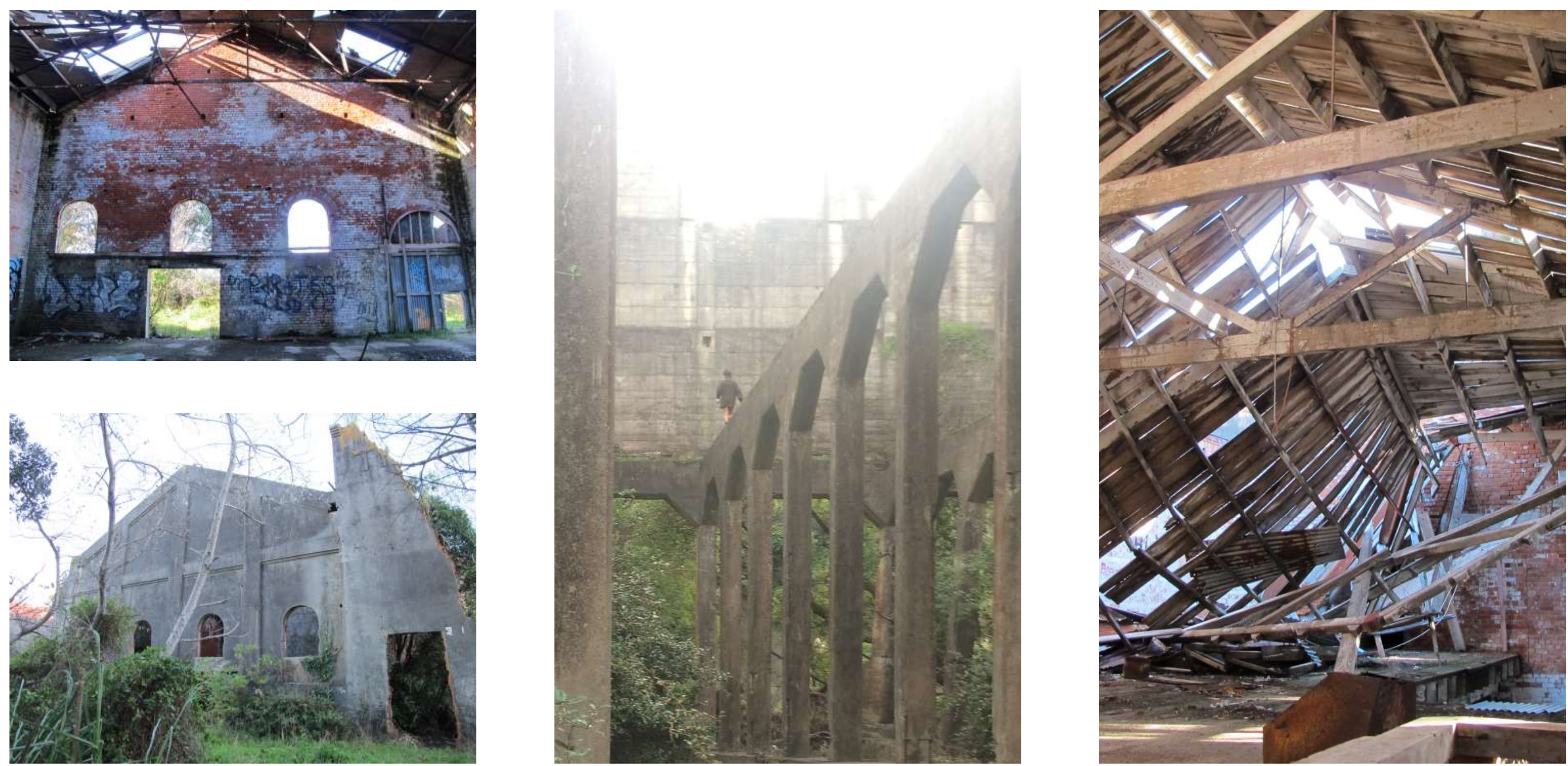

Figure 78 (above) Engine room interior.

Figure 76 Local girl walking along the freezing chamber extension as seen from the stream.

Source: Author's Image
Figure 77 Manure works roof beginning to collapse. Source: Author's Image 


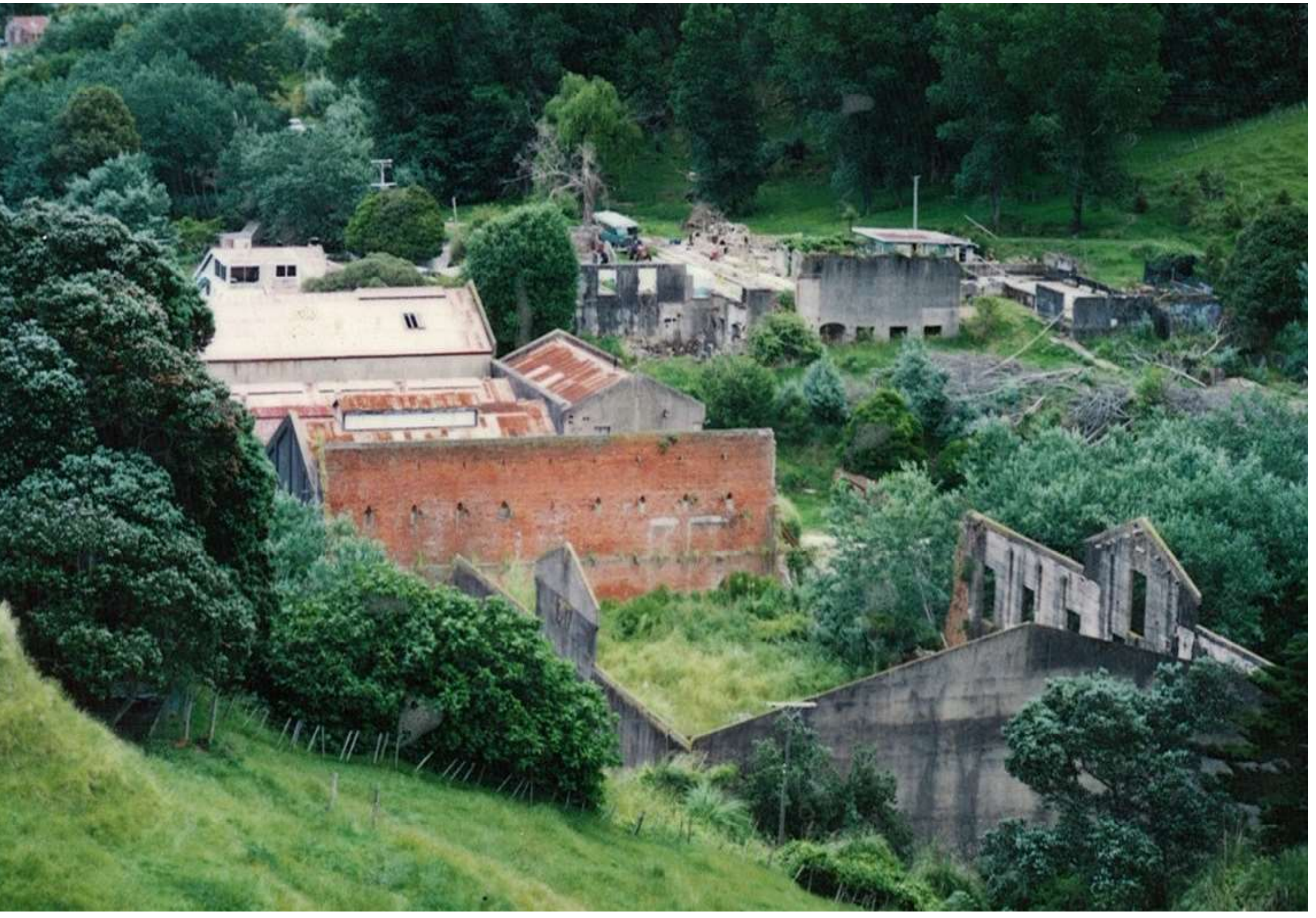



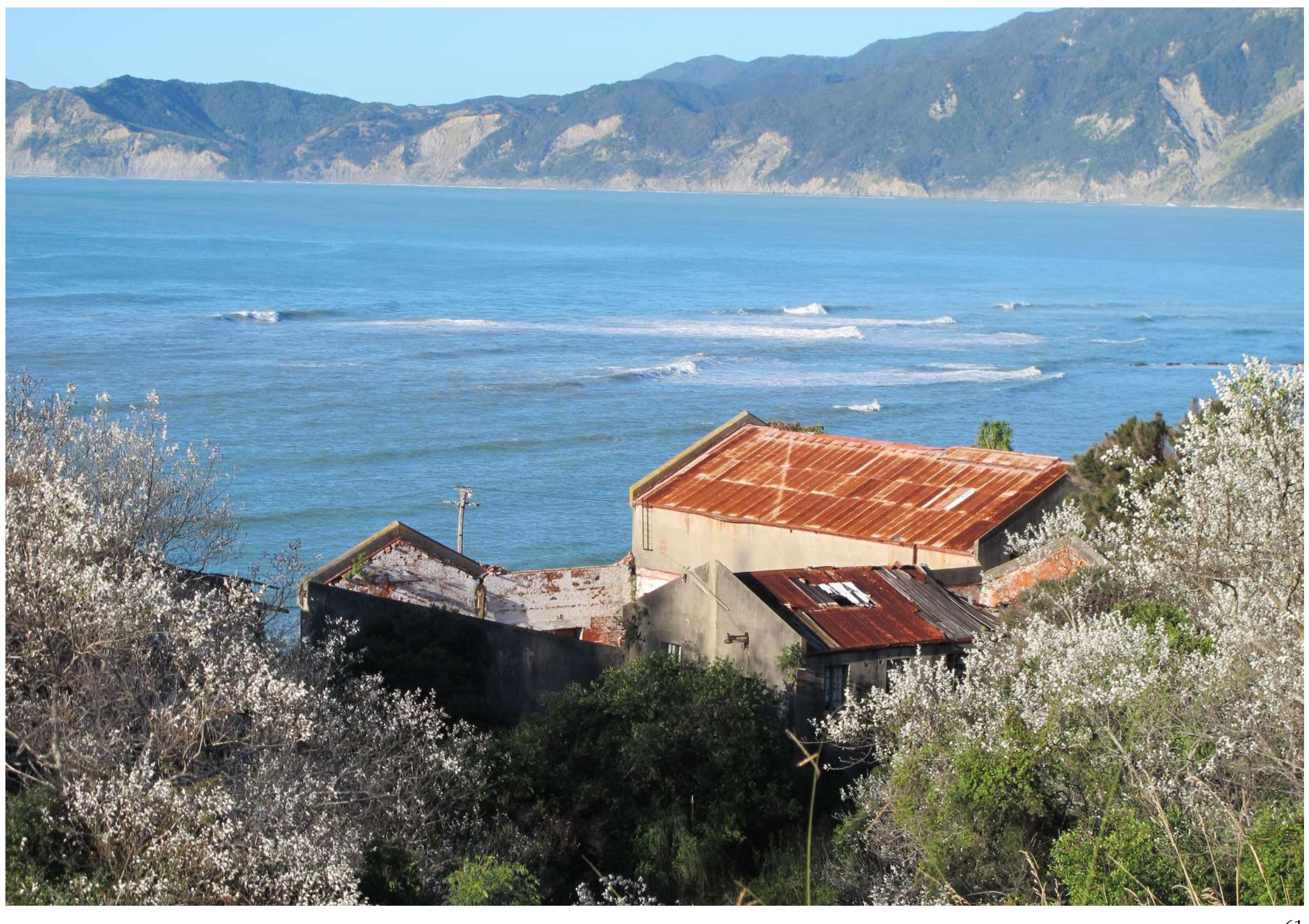


\subsection{Masonry Condition}

\section{Exterior Masonry with Plaster}

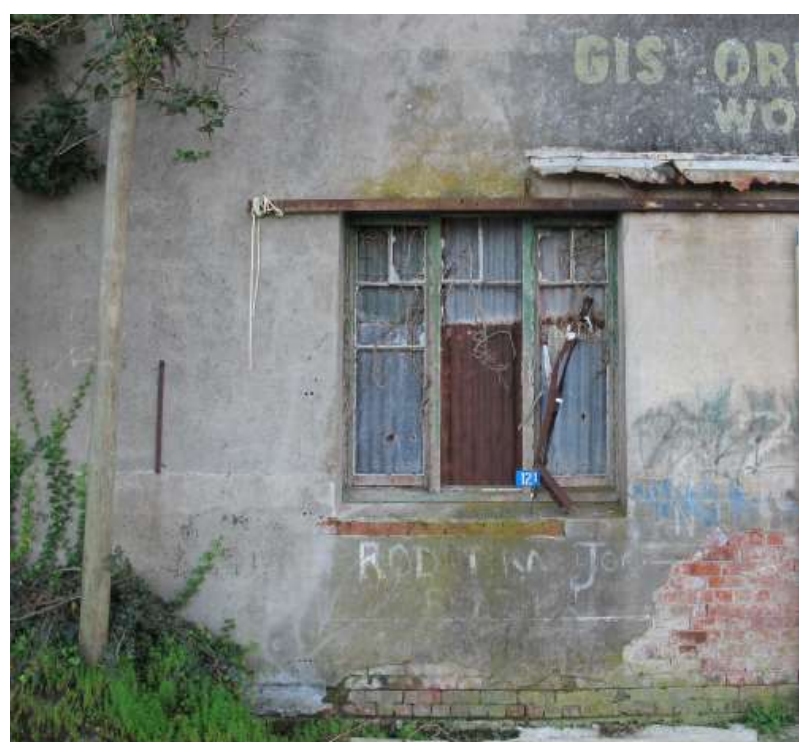

Interior Exposed Masonry

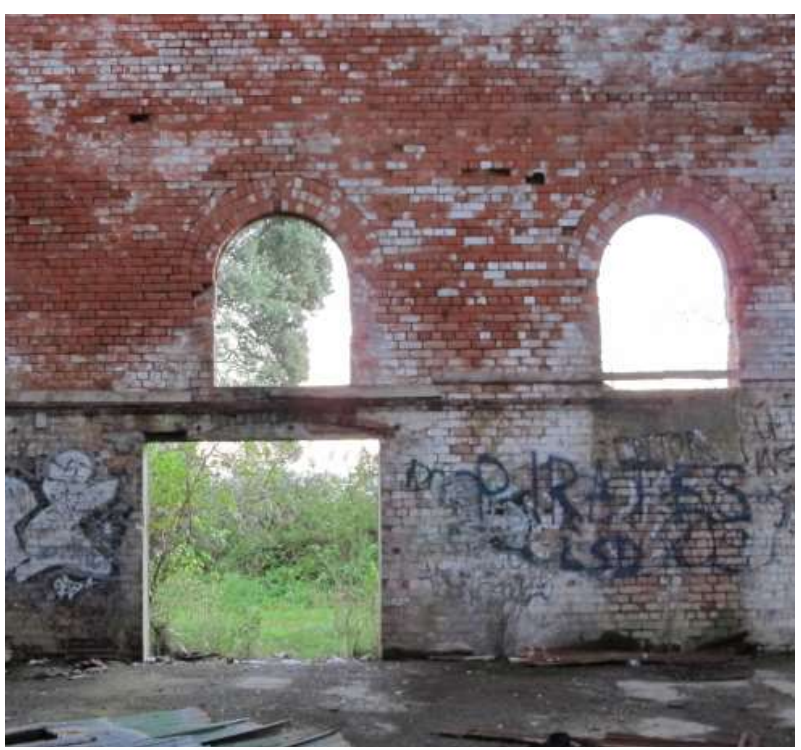

\section{Unreinforced Masonry}

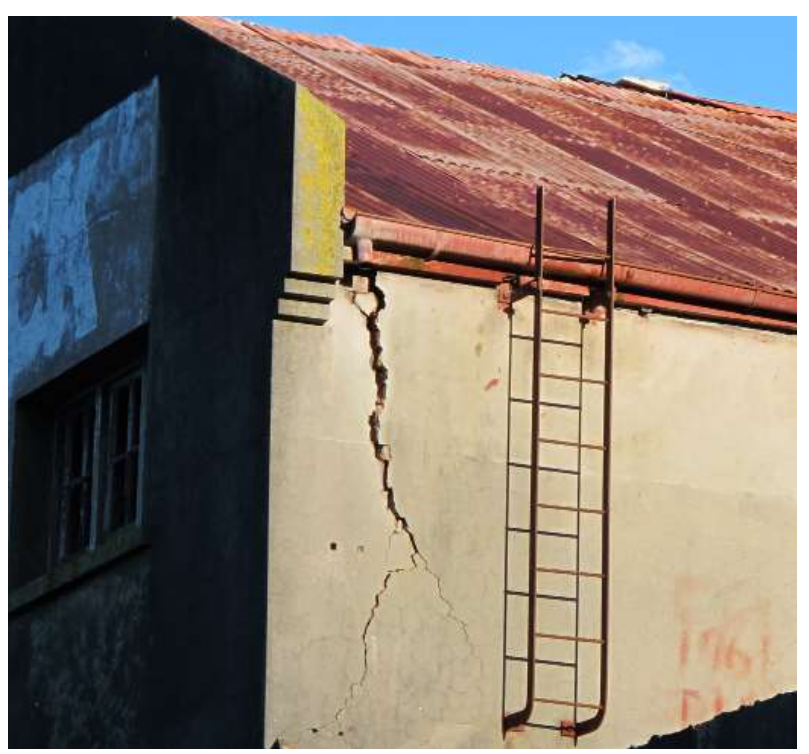

Figure 82 Exterior treatment of masonry buildings.

Source: Author's Image

Figure 80 (previous, left) Tokomaru Bay Freezing Works ruins surrounded by bush, mid 1990s.

Source: Tokomaru Bay Virtual Museum

Figure 81 (previous, right) Tokomaru Bay Freezing Works ruins coastal outlook, 2017. 


\section{Masonry in Ruins}

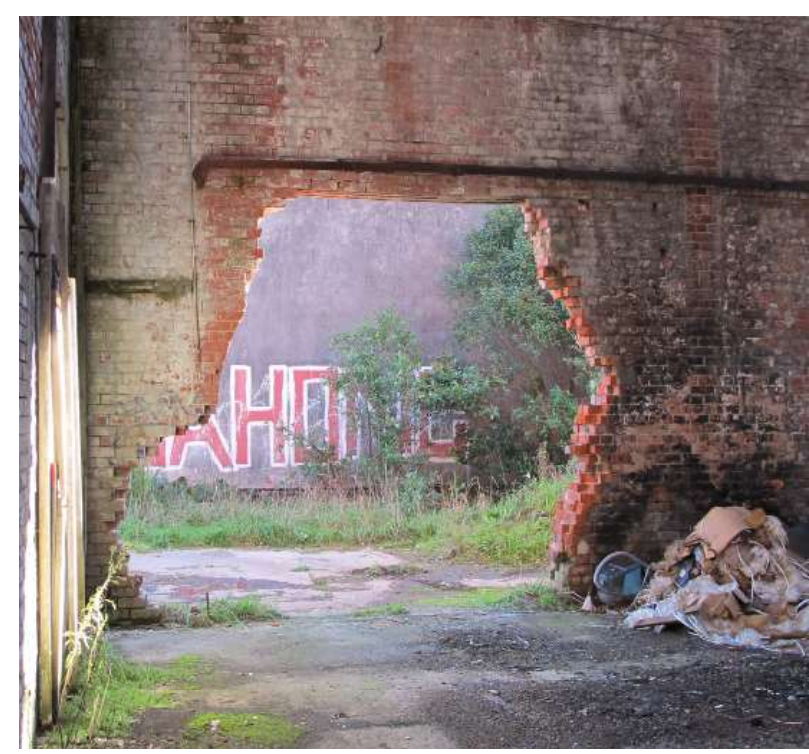

\section{Repairs}

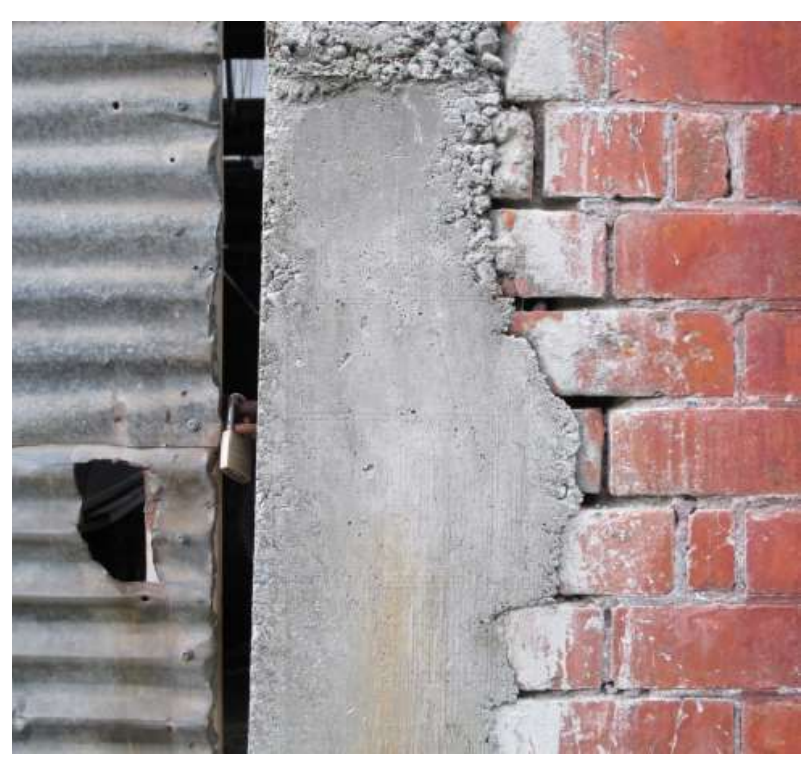

\section{Overgrown Masonry}

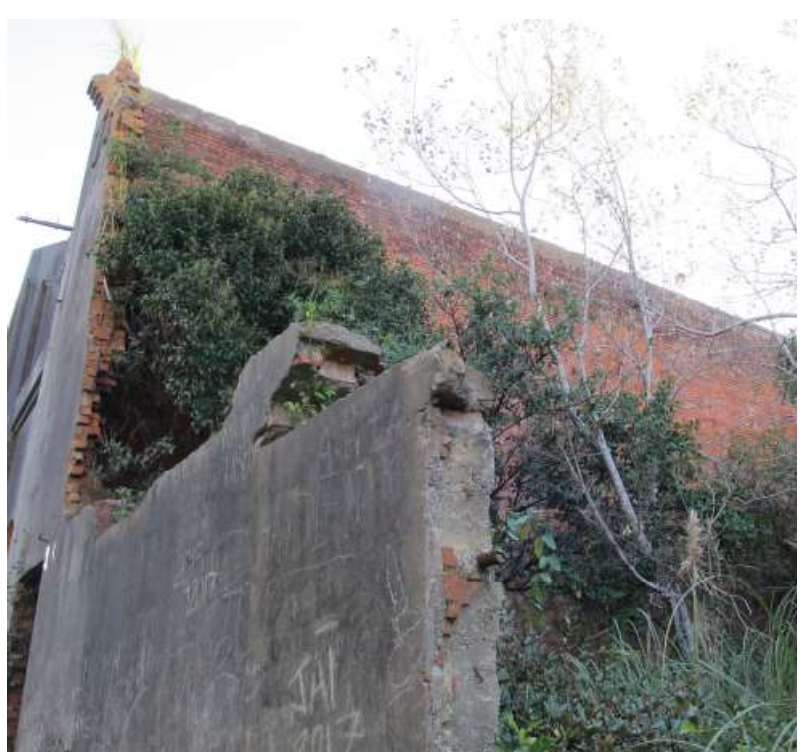




\subsection{Selected Site Analysis}

\subsubsection{Waima Cove Key Points}

- Waima Cove is South facing, surrounded by hills.

- Waima Cove is shallow with a rocky bottom, the wharf stretches out to reach the deepest water.

- Located at the End of the road, $4 \mathrm{~km}$ from Tokomaru Bay Township (off the main highway).

- Surrounded by hills and high points.

- Waihi Stream provides fresh water source

- The wharf dominates Waima Cove, and is a natural attraction, providing amazing vantages of Waima Cove and Tokomaru Bay.

- Heritage buildings/structures all in disrepair reminding of times gone by. The relationship between one another is being lost over time.

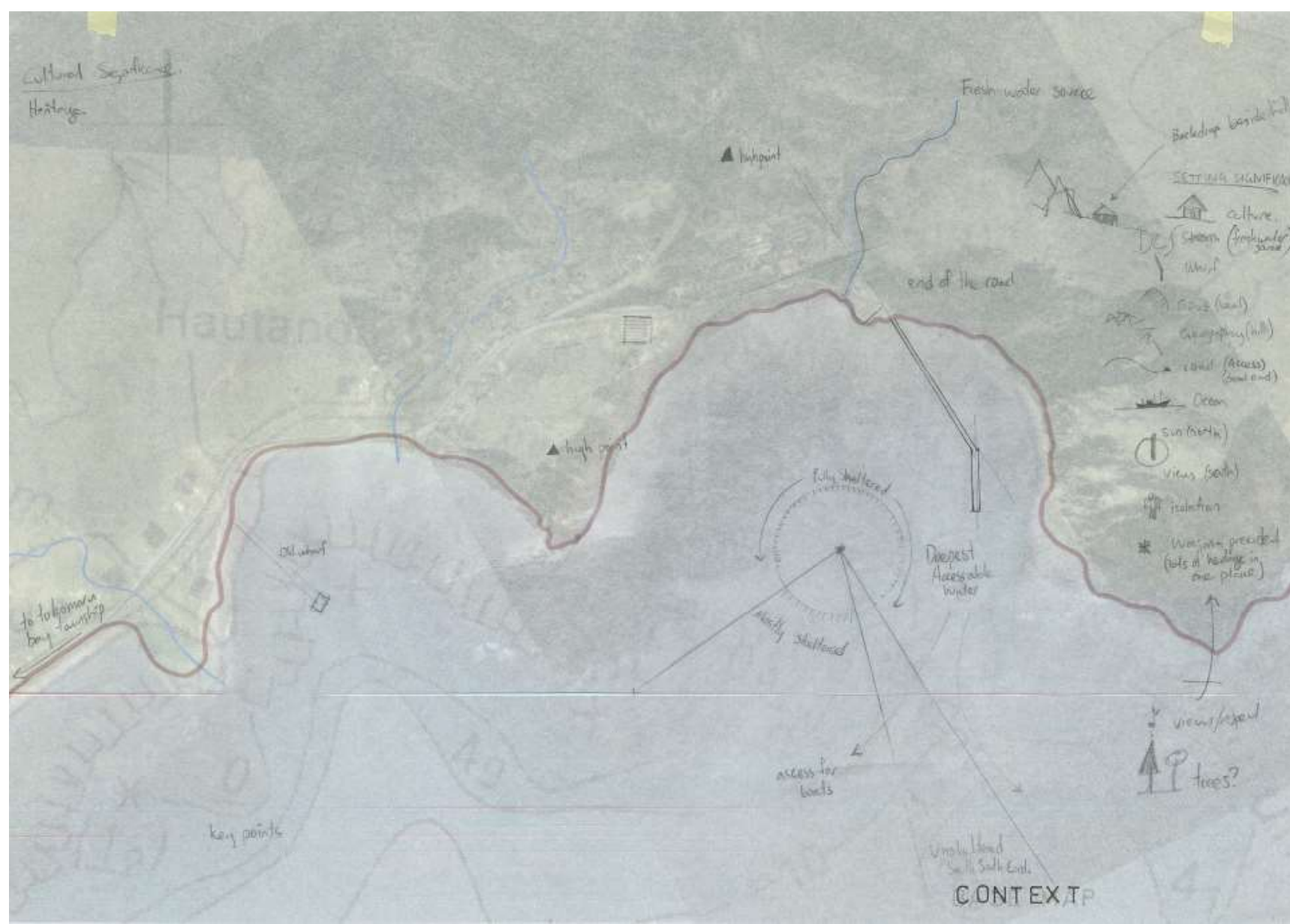




\subsubsection{Freezing Works Key Points}

- Freezing works is a large site with many buildings, which are either in ruins or have been demolished.

- Areas in between demolished buildings are overgrown with large trees. Concrete building footprints of demolished buildings are also becoming overgrown.

- The site has natural boundaries (ocean to the south, hills to the east, north and west), which constricted the layout of the freezing works). This will also impact any future development as all flat land has been occupied by the freezing works site.

- Although in ruins, the main facade facing the water is still preserved. Providing a strong connection between the site and its context.

- The buildings have rectilinear orientation that is based off the main façade.

- Freezing works have southern orientation, overlooking the water, and backed by hills to the north.

- Freezing works structures are typically built of unreinforced double brick construction on the perimeter walls with timber used for internal walls and floors. Today only the perimeter masonry walls remain. Buildings have simple gable roofs.

- Reinforced concrete extension over the stream is the most impressive part of the ruins, due to its sheer monumentality.

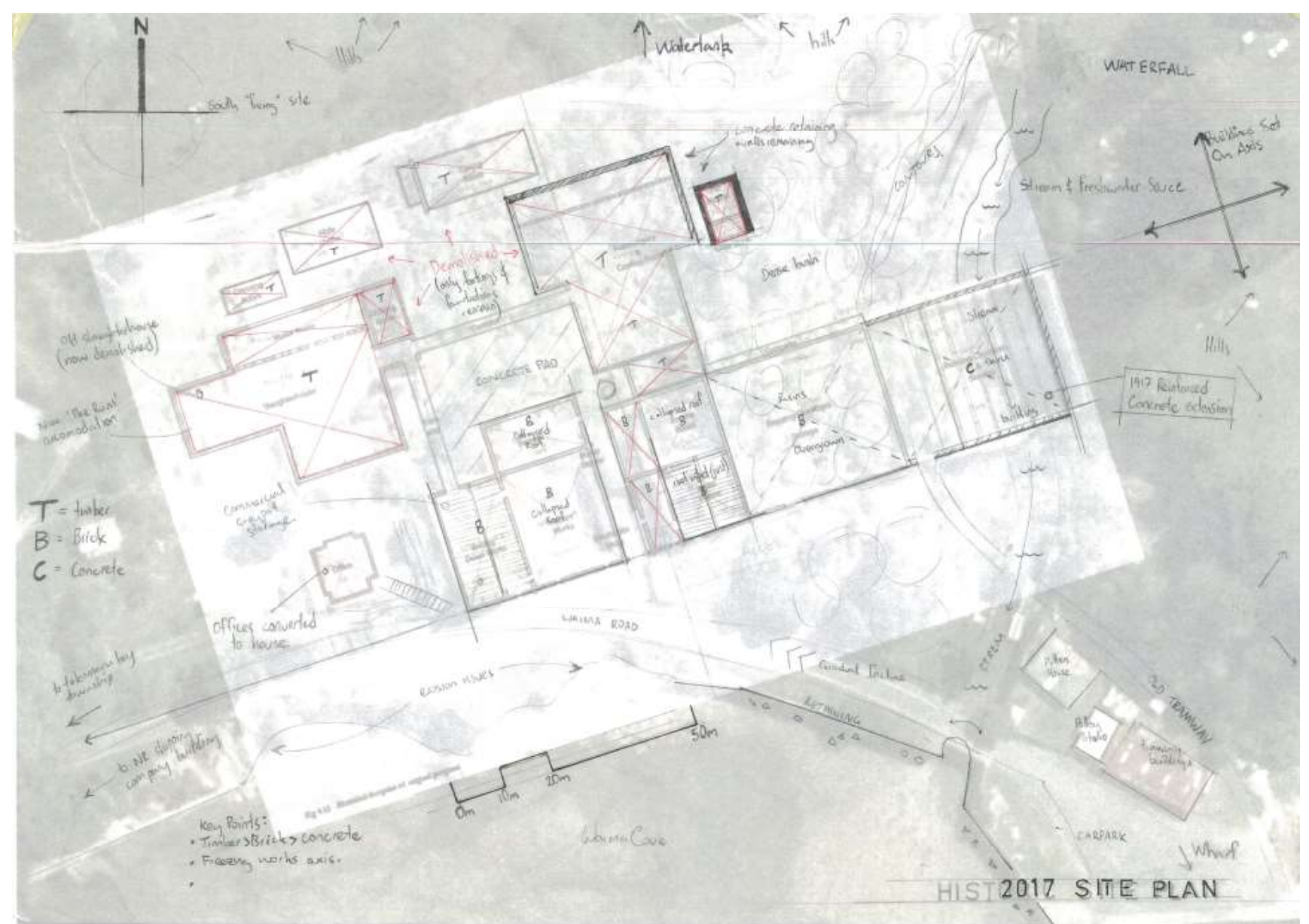

Figure 89 Tokomaru Bay site analysis (see appendix 1,2).

Source: Author's Image 


\subsection{Conclusions}

\subsubsection{Wider Site Conclusions}

Regional

- East Coast is an isolated region.

- Agricultural based industries dominate the region's economy (forestry and farming)

- Region has fragile land that is prone to erosion.

- Tokomaru Bay is one of 5 historical freezing works that operated in the region, each freezing works is either demolished or in ruins.

\section{Tokomaru Bay}

- Tokomaru Bay a small community typical of rural NZ struggling with decline.

- High unemployment due to lack of job availability.

- Heritage precinct at Waima Cove is a strong reminder of more prosperous times.

\subsubsection{Freezing Works Conclusions}

- The most intact buildings remaining on are the most suitable for adaptive reuse. Parts of the ruins not suitable for adaptive reuse could remain as ruins as a reminder of the heritage of the site.

- Parts of the freezing works have been completely lost.

- The site is an extremely large complex, depending on the selected programme only a portion of the existing site may be needed for adaptive reuse.

[Design principle 1c]

- U.R.M buildings will require strengthening to be inhabited again.

[design principle 2a]

- Built before automobiles, the site has no vehicular access.

- Relationship and connection of freezing works with the wharf and wool store needs to be reinstated.

- N.Z.H.P.T identifies that the remains of the freezing works have significance as an industrial ruin. The decayed state of the buildings serves as a reminder of the highs, lows and economic decline in rural New Zealand. The significance of the selected site represents what the freezing works contributed to Tokomaru Bay. The adaptive reuse of the freezing works will need to both acknowledge and reveal this significance in order to be successful.

\subsubsection{Design Guidelines Informed}

\section{Structure}

Laminated timber to seismically strengthen U.R.M.

\section{a. Strengthening}

Laminated timber to provide adequate structural support to existing U.R.M. 


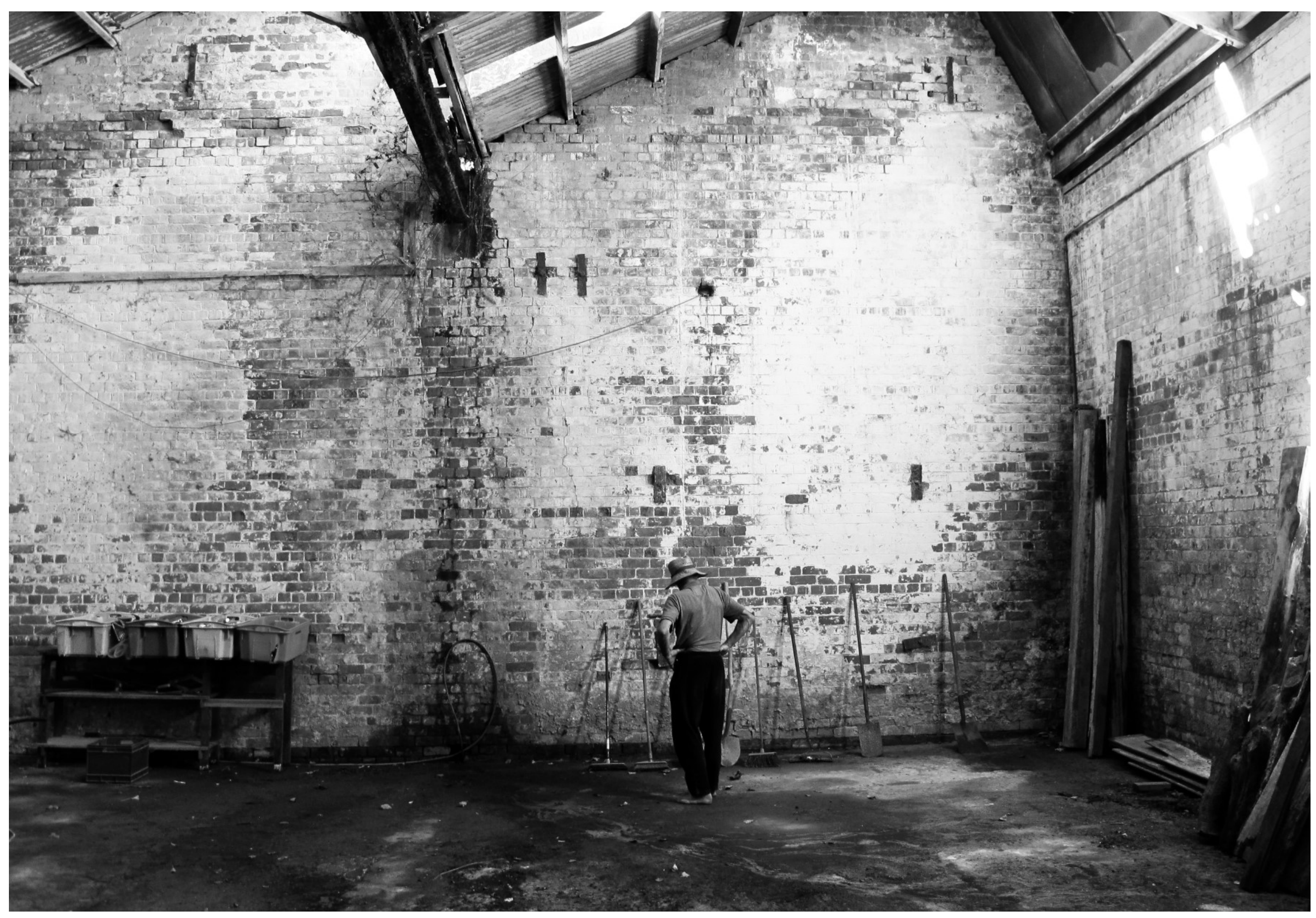




\subsection{Programme Analysis}




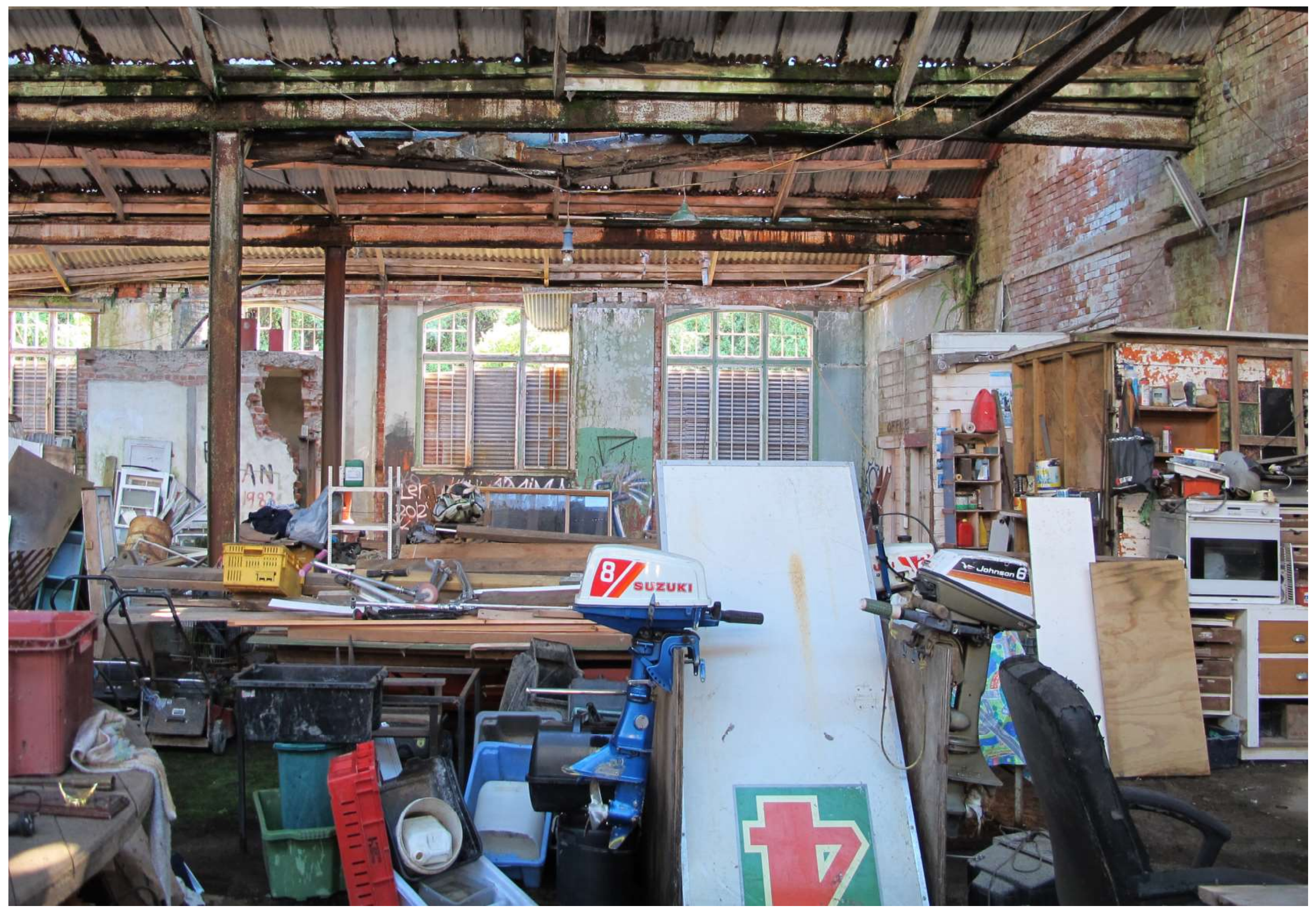




\subsection{Introduction}

This chapter provides a brief analysis of the selected programme for the adaptive reuse of the Tokomaru Bay Freezing Works.

The adaptive reuse guidelines in chapter two state that once the significance of a heritage site has been established a programme that is appropriate to that significance can be selected.

The heritage significance of the Tokomaru Bay freezing works was identified in chapter 3 and relates to its role as a reminder of the highs, lows and economic decline in rural $\mathrm{New}$ Zealand.

While acknowledging heritage significance of the site, there are also other site-specific considerations that affect the suitability of the programme for the Tokomaru Bay site.

\subsection{Programme Selection}

\section{Tokomaru Bay Honey Co-operative}

A mānuka honey factory and mānuka plant nursery have been selected as the new programme for the adaptive reuse of the Tokomaru Bay Freezing Works site. This programme is compatible with the existing site and allows the heritage to be acknowledged. The new programme aims to endorse the significance of the site in the future; and contributes to the wider Tokomaru Bay community.

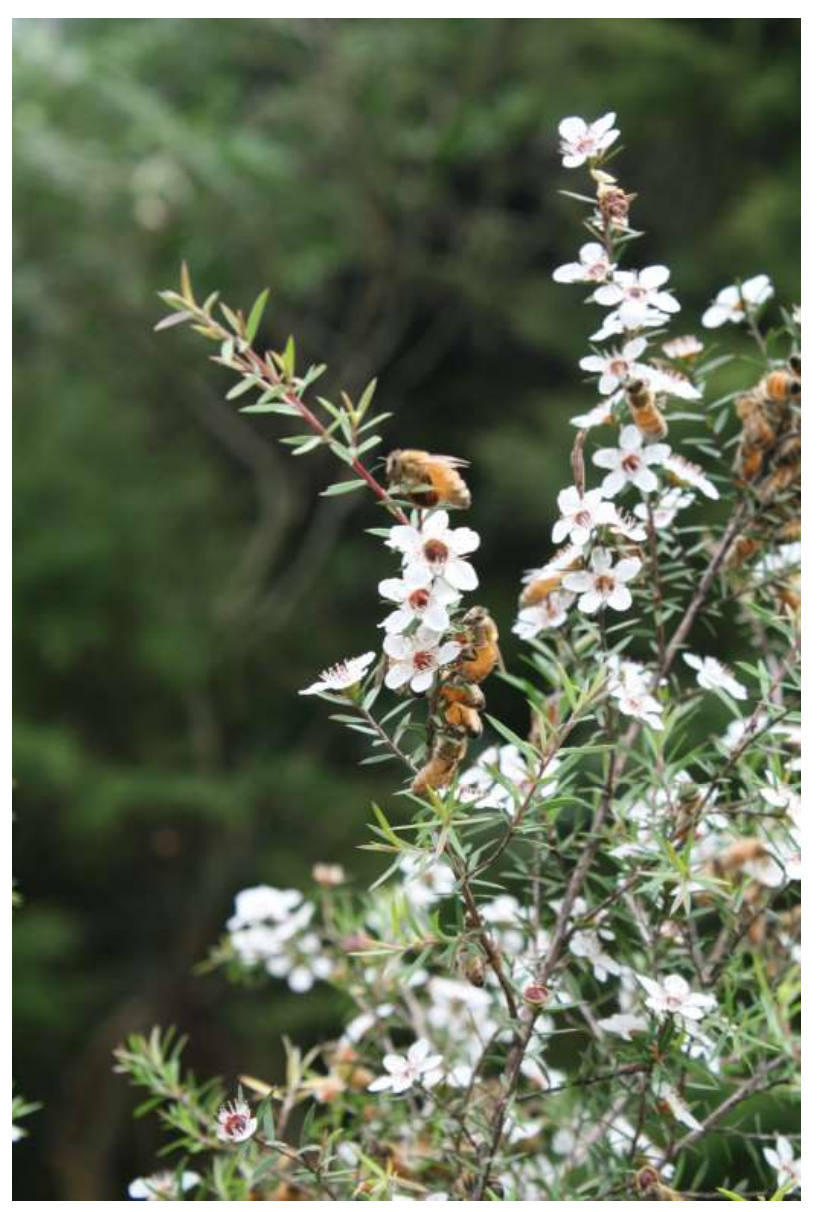


The following programme considerations outline why the selected programme is suitable for the design case study.

\section{Heritage Significance}

Honey co-op to be accommodated within the existing freezing works ruins allows the heritage significance to be expressed.

\section{Adaptive Reuse}

Honey co-op is suitable for adaptive reuse as it is not reliant on a specific building or site to function. Any changes made to the site will be reversible to allow for future interpretations of the heritage site.

\section{Community}

Honey co-op will build community identity and help put Tokomaru Bay back on the map.

\section{Regional Isolation}

Honey co-op is not hindered by the isolation of the site. The agricultural nature of the programme lends itself to a regional setting and its success does not depend on an urban location. Honey is a small, high value product, which can be economically trucked to the nearest port in Gisborne.

\section{Local Employment}

Honey co-op creates new jobs for residents in a region with high unemployment.

\section{East Coast Geology}

Mānuka plants from the nursery within the Honey co-op will be planted on marginal farmland unsuitable for livestock and recovering forestry blocks throughout to mitigate erosion on the East Coast.

\section{Economically Sustainable Solution:}

Honey co-op aims to provide economic sustainability for the future of the township. The business will be co-operatively owned by residents, farmers and local iwi, which means benefits remain in the community. Honey is a growing industry based on a renewable resource. mānuka plantations will diversify incomes for farmers by providing another form of revenue.

\section{Environmentally Sustainable Solution:}

The creation of the honey co-op will promote the plantation of Mānuka, making practical use of steep farmland unsuitable for stock. It is an environmentally sustainable solution in a region that has struggled with the effects of overintensive agricultural practices on marginal land. Providing an alternative to forestry, the new programme promotes the planting and regeneration of native bush. Furthermore, bees have vital economic importance, as they are needed for the pollination of many flora, fruit, vegetable and seed crops.

\section{Visitor Interaction:}

The honey co-op encourages visitors on the site to engage with the industrial heritage, honey factory and mānuka nursery. This allows visitors to Tokomaru Bay to stop and spend meaningful time in the township.

\section{Local, Regional, National Benefit:}

Honey co-op aims to have a positive effect at three scales:

- Local: Artisanal food producer.

- Regional: Represents what the East Coast can offer to New Zealand.

- National: High value, sustainable product that reflects values of what New Zealand strives for. 


\subsection{Programme Background}

\subsubsection{What is Mānuka Honey?}

Bees collecting nectar from the flowers of the mānuka plant produce mānuka honey. Mānuka grows well across New Zealand in a range of conditions and usually flowers for 6-12 weeks in early summer. Mānuka plants have a life span of 25 years and are considered the first step in native forest regeneration in New Zealand.

Mānuka grows naturally in New Zealand and is highly sort after for its healing and antibacterial properties. This is measured by the Ultimate Mānuka Factor (U.M.F). The U.M.F grading system appraises natural markers found in mānuka honey, which assures purity \& quality (Comvita).

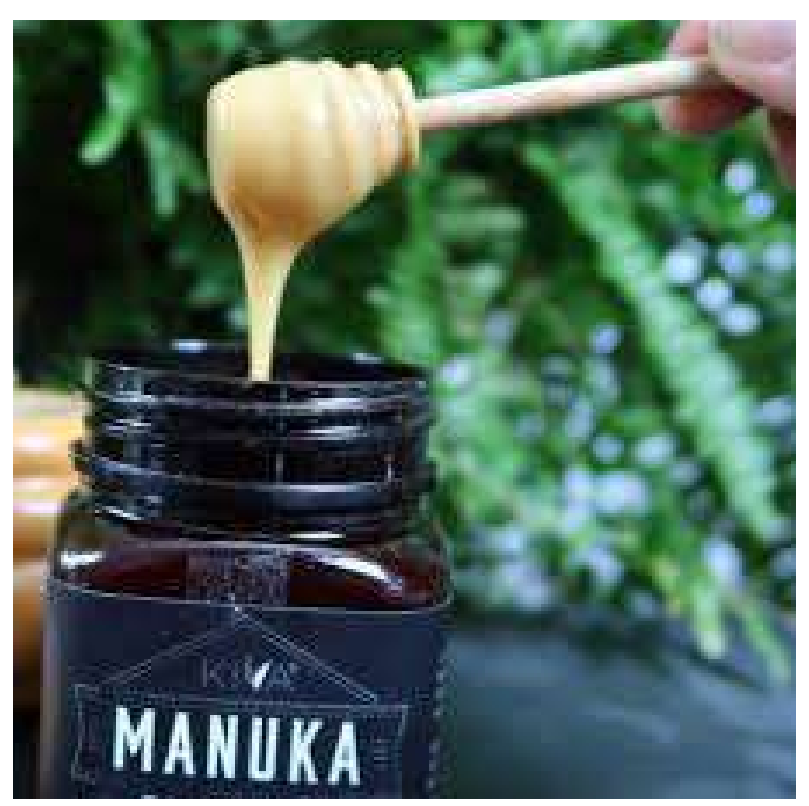

\subsubsection{Programme Requirements}

\section{Mānuka Honey Factory}

800 square metres for a commercial honey factory.

Amenities required for honey factories are water, electricity and vehicle.

\section{Mānuka Plant Nursery}

The nursery will breed varieties of high performing Mānuka that perform well in local conditions.

\section{Visitor's Centre}

This encompassed a cafe/shop, museum, gallery, and tours (around honey factory, mānuka nursery and freezing works ruins).

An allowance for growth and expansion in the future will also need to be considered within the heritage site.

Be adaptable to diversification and changes in the honey industry, and have provision for other enterprises to join the area in the future. 


\subsubsection{Honey Production Process}
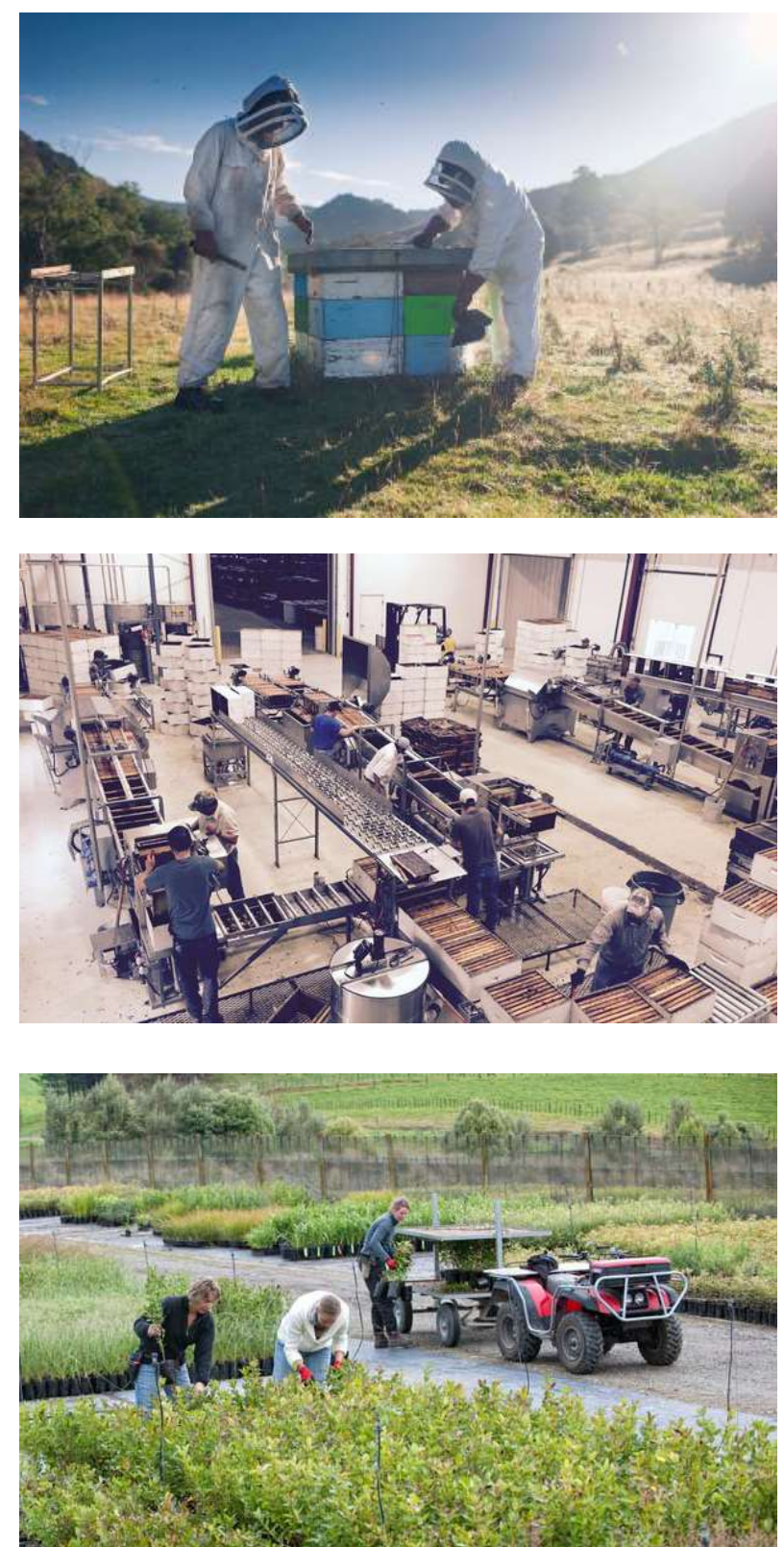

1. Hives are brought in for processing.

2. Large loading and storage area required for hives.

3. Hives are moved to hot room to warm up.

4. Beeswax and other by-products removed.

5. Honey is extracted, and empty frames go back to storage. Honey moves to tank room.

6. Honey is filtered, blended and creamed to desired quality (if necessary)

7. Honey is bottled and labeled.

8. Product is in storage until shipped.

Other areas required in the building are back of house areas for staff, office space and an area to process honey by-products.

Figure 94 (top) Apiarist inspecting a bee hives. Source: Alden Williams

Figure 95 (middle) Honey factory extraction process. Source: Dirk Lammers

Figure 96 (bottom) Kauri Park Mānuka Nursery Source: Tracey Robinson

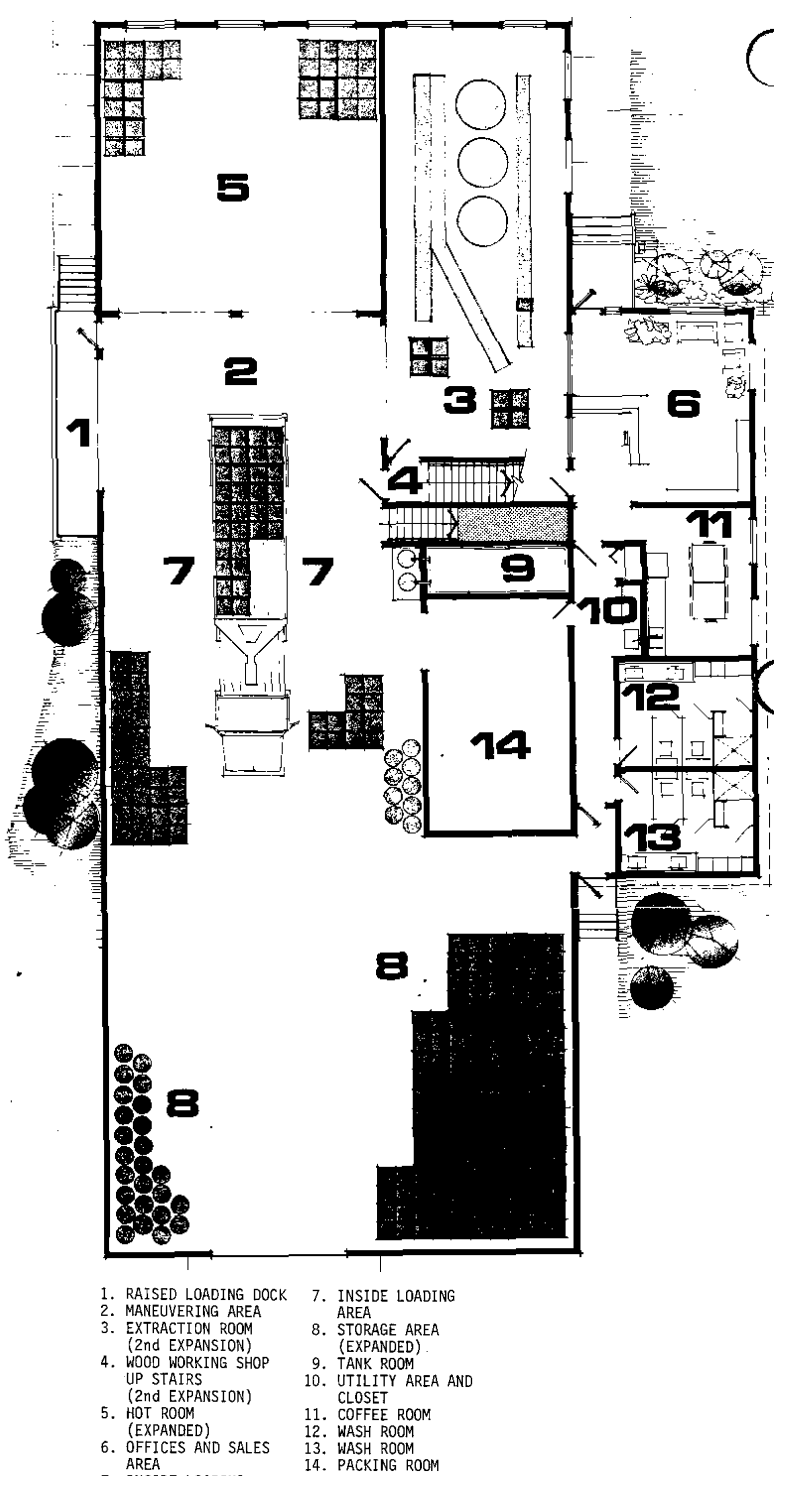

Figure 97 Typical Honey Factory Floor Plan Source: Alberta Agriculture 


\subsection{Programme Background}

\subsubsection{Honey Industry Statistics}

Because of its natural health benefits and anti-bacterial qualities, New Zealand grown Mānuka honey has become highly sought after, which has led to a surge in global demand.

New Zealand Mānuka honey is the most expensive in the world and receives a significant premium over other honey products. New Zealand is the world's third-largest exporter of honey by value, behind China and Argentina. However, it is only the 16th biggest global supplier on a volume basis, reflecting the premium price garnered for Mānuka honey, which accounts for as much as $80 \%$ of $\mathrm{New}$ Zealand honey exports (NZ Herald).

New Zealand's honey exports have surged from \$36 million annually in the mid 1990's to $\$ 285$ million in 2015. A government and industry primary growth partnership aims to increase the annual value of New Zealand's Mānuka honey industry to $\$ 1.2$ billion by 2028 (Morrison). It is a premium product that is growing steadily as a high-value export for New Zealand (Ministry for Primary Industries).

The rise of Mānuka honey has ensured that Mānuka plantations are also in demand. Historically Mānuka trees were classified as scrub and rendered farmland useless until it was cleared. Today more and more Mānuka is being planted on marginal farmland as an alternative to traditional farming practices, while providing economic diversity at the farm gate.

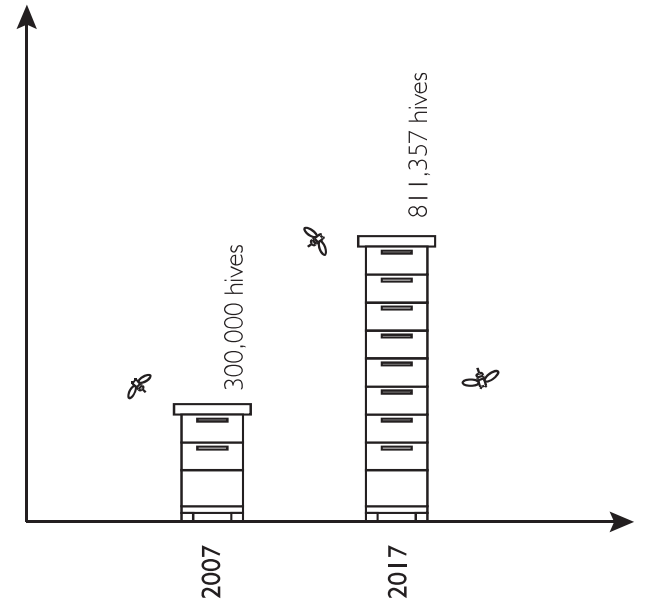

Figure 98 Total hives in New Zealand (Apiculture NZ). Source: Author's Image

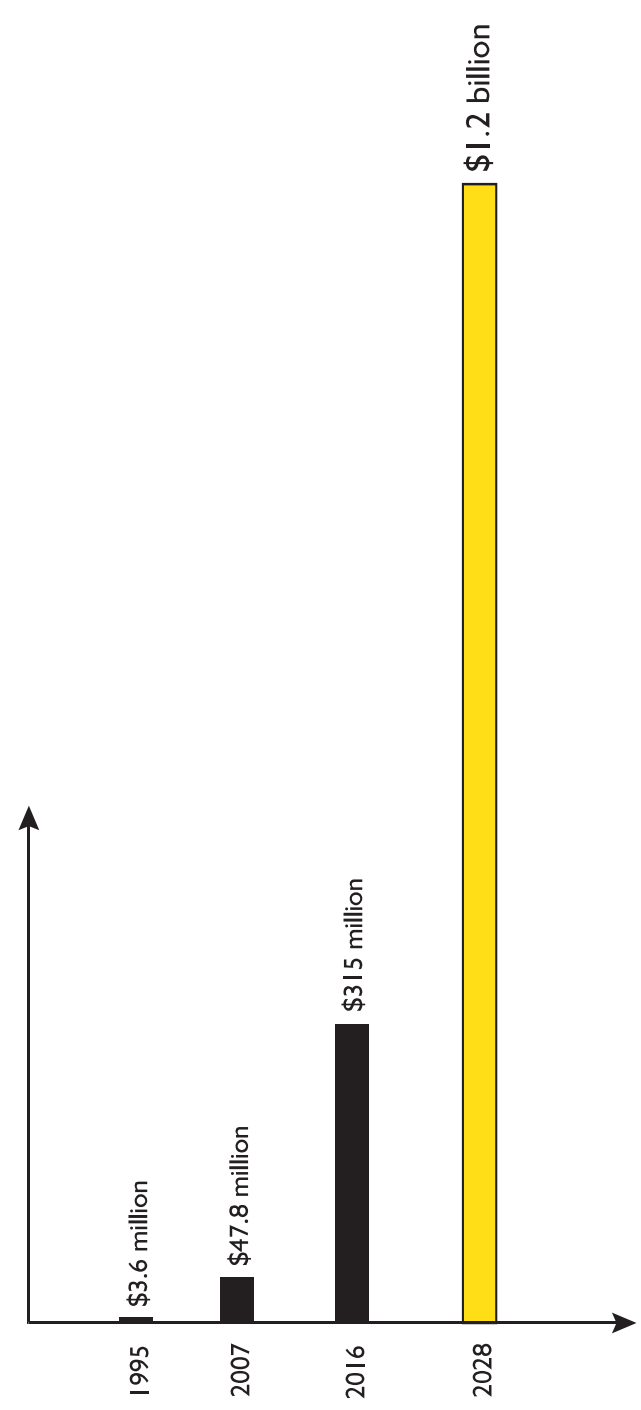

Figure 99 New Zealand annual honey exports. Source: Author's Image 


\subsubsection{Honey By-products}

There are four natural by-products that occur through the honey process, three of them are used as natural health products.

- Beeswax is produced by worker bees to cap the honeycomb. Prior to extraction, wax is removed from the frames and melted down. The wax is used for candles, lip balms, moisturiser, cooking and other health remedies.

- Propolis is produced by worker bees and is used to maintain the health of the hive. Propolis is used as a as dietary supplement.

- Royal jelly is food produced by worker bees and given to the queen bee and infant bees.

- Royal jelly is used as a dietary supplement.

- Bee pollen is collected by worker bees from flowers. Bee pollen is used as a vitamin supplement.

Research is being conducted into the benefits of natural oils provided by Mānuka an Kanuka, which could provide other by-products in the future. Although small, these areas are valuable products of the honey process and could potentially grow in the future. An area within the honey factory will be dedicated to honey by-products and their development.
Bees Wax

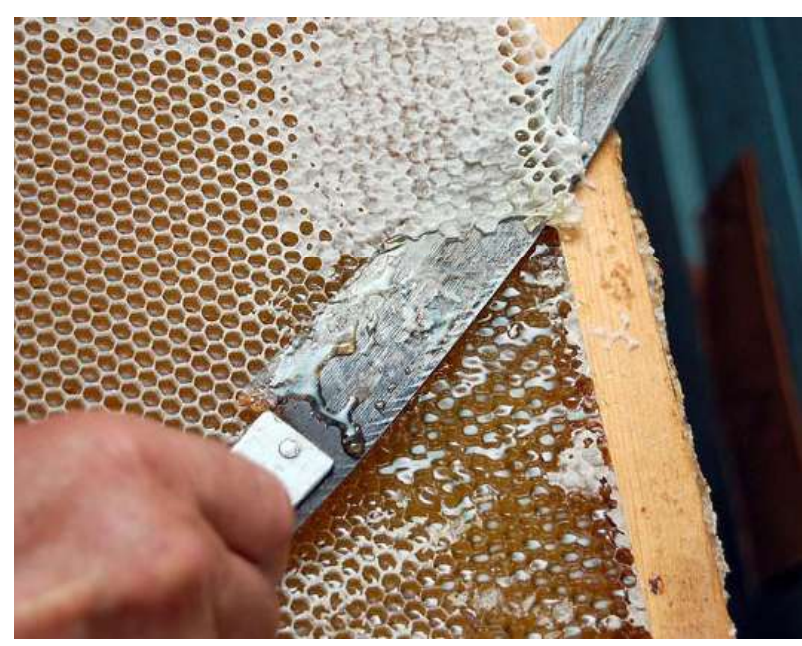

Bee Pollen

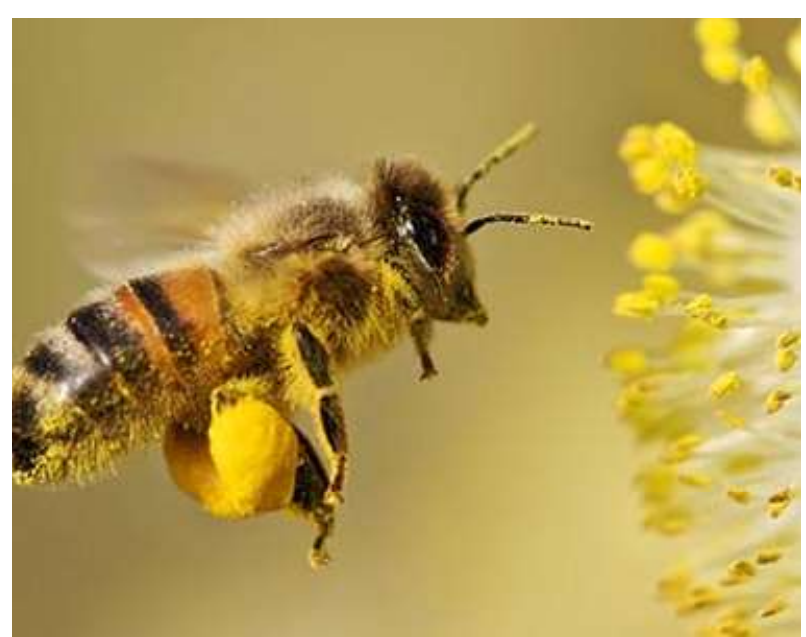

Figure 100 Beeswax is used for making candles, furniture polish, skin care, balms and soaps.

Source: Sweetree Honey

Figure 101 Bee pollen is rich in vitamins, minerals, proteins, lipids and fatty acids.

Source: Urbol
Propolis

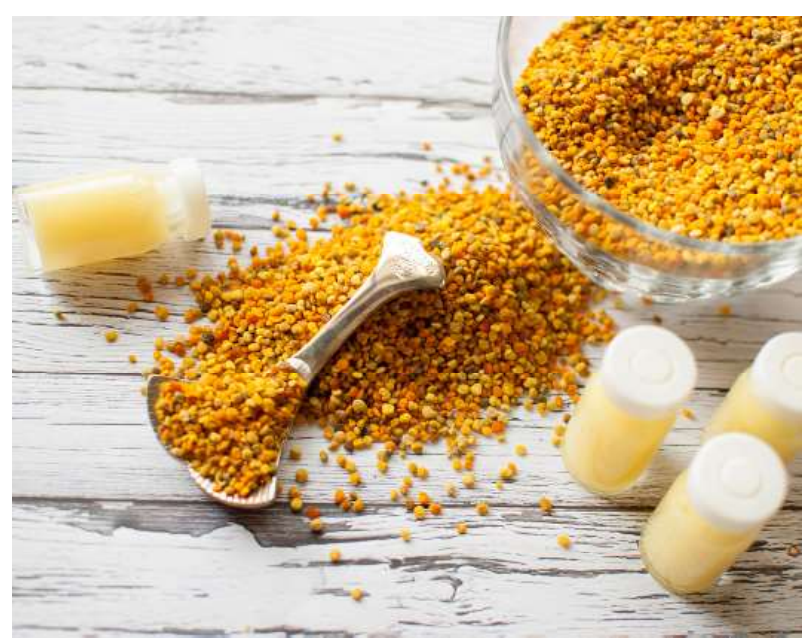

\section{Royal Jelly}

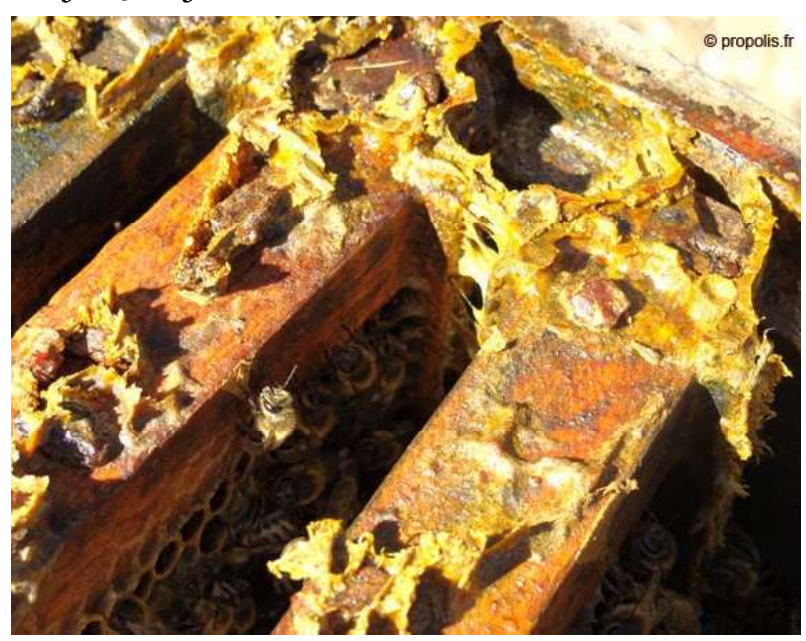

Figure 102 Propolis has antibacterial, antiviral, anti-fungal and anti-inflammatory properties.

Source: Sarah Orecchia

Figure 103 Royal jelly has of anti-tumour, antibacterial, antiinflammatory and wound healing properties.

Source: Healthbenefitstimes 


\subsection{Relationships within the \\ Research}

The selection of a honey factory as the new programme integrates with relationships within the research.

High-value product Renewable / sustainable product Rurally Focused (non urban)
Reflects shifts in NZ agriculture toward higher value products.
Industrial Heritage

New Material

(laminated timber)
Freezing Works (industrial heritage)
Honey Factory/ Nursery

(adaptive reuse) 


\subsection{Conclusion}

This chapter identifies the selected programme for the adaptive reuse of the Tokomaru Bay Freezing Works. Honey is a high-value growth industry that aligns with the direction of New Zealand agriculture. A Mānuka honey factory is a viable programme for the Tokomaru Bay site and allows engagement with both the new honey factory, and the ruins of the former freezing works.

Factors influencing the selection of the Mānuka honey factory and nursery are:

- Appropriate to the heritage significance of the freezing works ruins.

- Compatible with the existing site.

- Addresses wider considerations applicable to Tokomaru Bay and the East Coast region.

There is symmetry between the honey industry and laminated timber industry, which reinforces the appropriateness of the chosen programme within the design research. Both are growing industries in New Zealand, producing high value products that can be exported. New Zealand is a world leader in both industries, and they are viewed as sustainable/renewable industries.
Housing a honey factory within the ruins of a freezing works shows the shifts in the New Zealand agriculture industry from lower value bulk products (logs \& carcasses) toward high value commodities (engineered timber, honey and dairy). It acknowledges the significance of the site by locating a new, sustainable programme within the existing ruins of an old, unsustainable agricultural industry. The proposed programme aims to add to the heritage significance of the site and allow Tokomaru Bay to be economically sustainable.

This programme selection chapter is relevant as it activates the 'adaptive reuse' component of the research, and it allows decisions regarding the material relationship between U.R.M and laminated timber to be made. 


\subsection{Design Iterations}




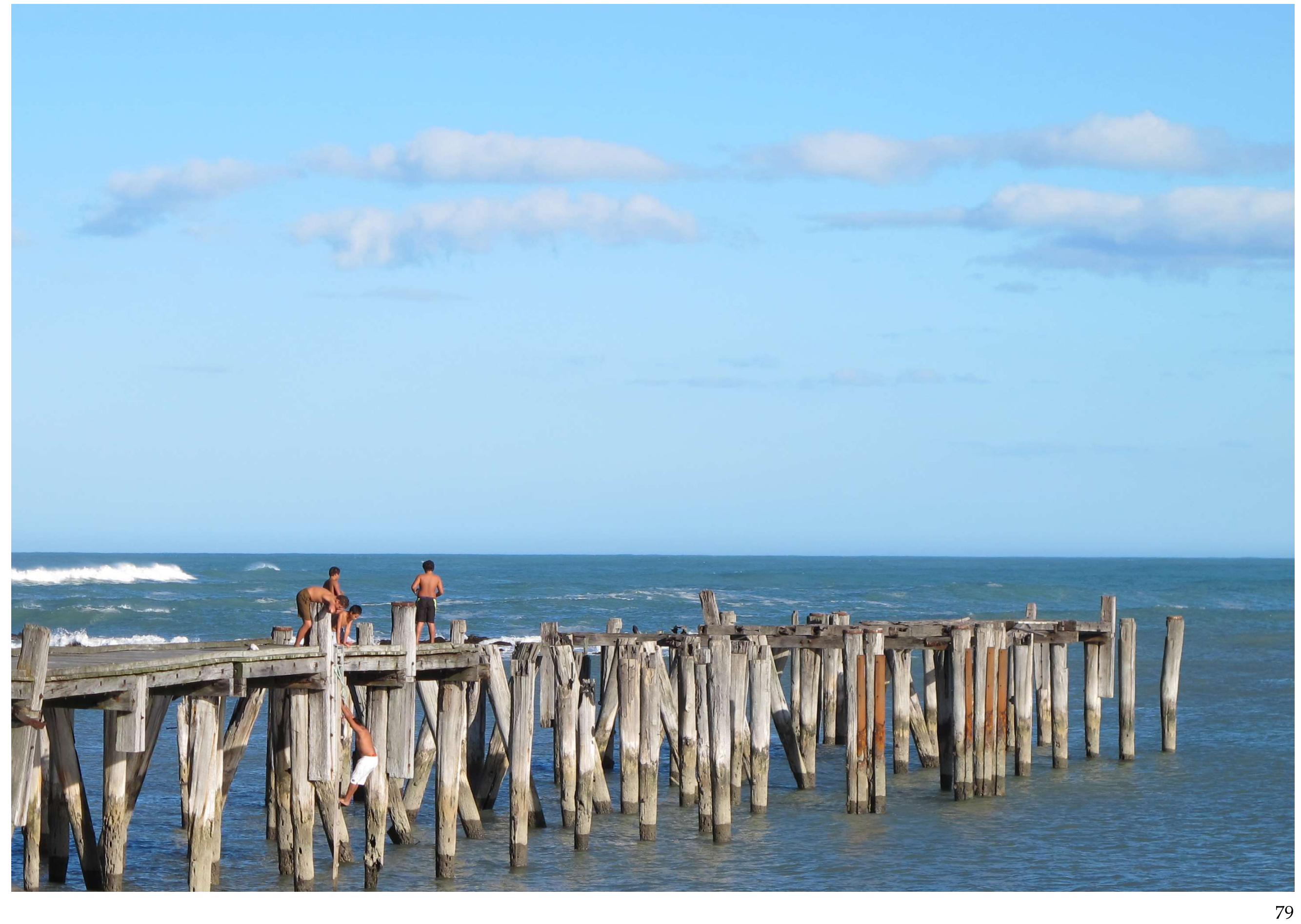




\subsection{Introduction}

This chapter shows how 6 iterations make up the design process, leading to the final design.

The first iteration is precedent analysis, which looks at three examples of existing heritage buildings that have been adaptively reused using a form of laminated timber, which aligns closely with the research question. Each of the precedents differ in size and scale and are analysed against the five design criteria.

The second iteration is the identification of design strategies from the precedents, which catalogues the interaction of laminated timber and masonry.

Iteration three consists of abstract, site-less modeling of design strategies in different scenarios.
Iteration four uses the site analysis chapter to inform an initial concept for the design case study, and determines how the freezing works ruins will be used.

Iteration five sees design strategies developed through modeling of the freezing works ruins with laminated timber. This iteration uses the programme analysis chapter to develop the adaptive reuse component of the research and explores how laminated timber can enable a honey factory to operate within the heritage site.

Iteration six is the developed design stage of the case study. This shows further refinement of the design strategies and their application within the former freezing works.

This culminates in iteration seven, which is the final design for the case study 


\subsection{Design Iterations}

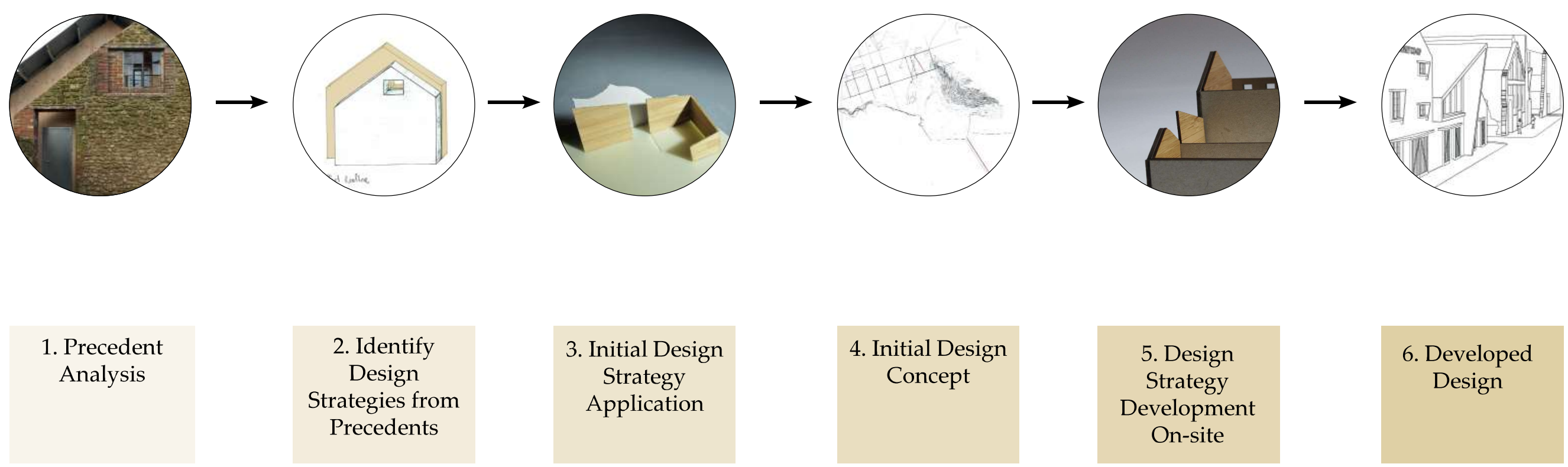




\subsection{Iteration 1: Precedent Analysis}

\subsubsection{Small Precedent}

Name: S(ch)austal

Location: Rheinland-Pfalz, Germany

Architect: FNP Architekten

Constructed: 1780

Date of re-use: 2005

Former use: Cottage

New use: Studio

Key features of precedent: laminated timber, unreinforced masonry, adaptive reuse, heritage.

Key design strategy: Insertion

A humble design that captures the essence of this research. Built in the 18th century, damaged during WWII, and prior to its renovation, was being used as a pig sty (German for Schaustal). L.V.L has been delicately inserted within the existing masonry envelope. The adaptive reuse of this structure has enabled a new programme within the masonry building and serves its significant qualities.

As a relatively small project, this underpins the process of keeping historic building envelopes as 'building sleeves' for an insertion.
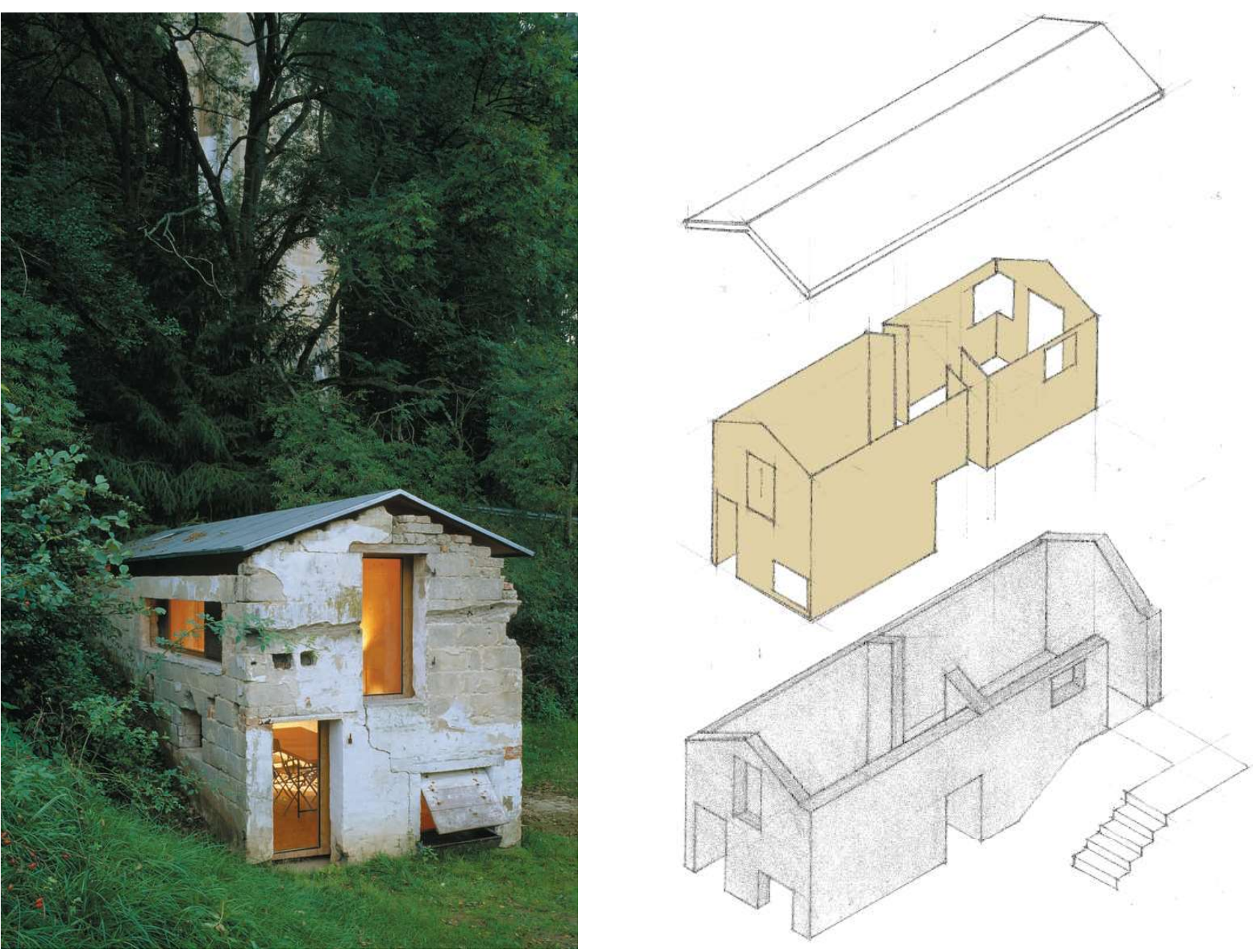


\section{Design Criteria Analysis}

\section{Character}

Small and humble, the new laminated timber housed within the existing masonry, preserving the setting of the building and its context.

\section{Structure}

L.V.L and existing masonry are separated. Masonry remains unreinforced. L.V.L supports roof structure.

\section{Heritage}

Architectural intervention is internal, preserving the relationship between the existing structure and its setting in the woods.

\section{Envelope}

Openings between masonry and L.V.L are aligned to allow permeability between onside and out. Looking through the openings from the outside, L.V.L is visible thus showcasing the buildings new use. [design principle $4 \mathrm{~d}$ ]

\section{Programme}

L.V.L insertion allows historic ruins to have a practical use such as an office or meeting space.
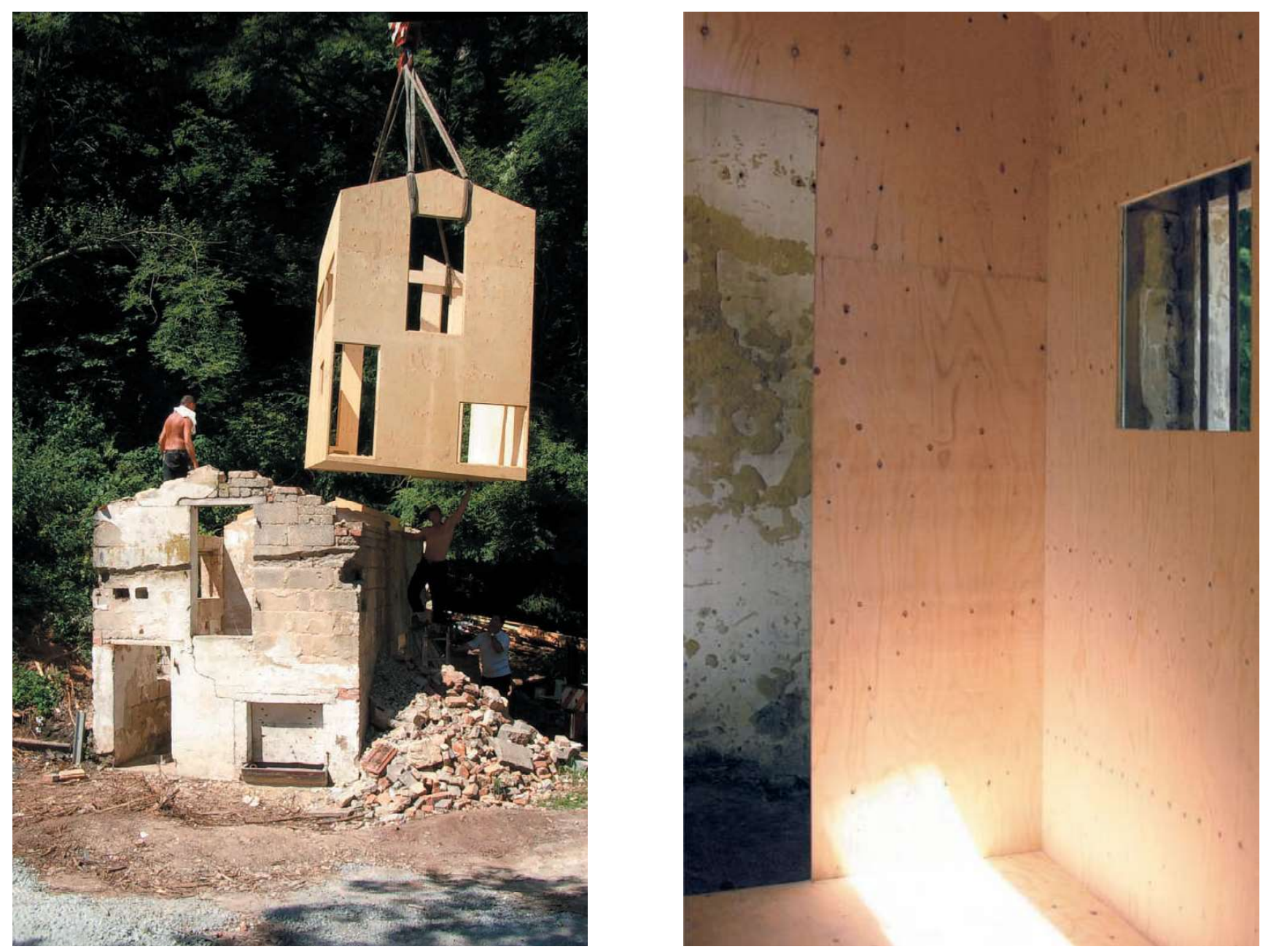

Figure 110 S(ch)austal interior. Source: Zooey Braun 


\subsection{Iteration 1: Precedent Analysis}

\subsubsection{Medium Precedent}

Name: Architecture Archive

Location: Somerset, England

Architect: Hugh Strange

Constructed: 19th century

Date of re-use: 2014

Former use: Barn

New use: Archives and office

Key features: laminated timber, unreinforced masonry, adaptive reuse, heritage

Key design strategy: Altered roof pitch

Located within a rural setting, two timber structures have been inserted within the remains of an old barn, with a single over-sailing roof. Architect Hugh Strange states, "there was no temptation to create a monument". As a result, the new building sits unpretentiously in its setting, the interiors are sleek and refined providing a contrast between new and old.

The adaptive reuse of the site allows a new program to occur within a formerly dilapidated building. The south building is an archive and display space with skylights above, while the north building is an office space with views of the woods outside.

Constructed from C.L.T, the building has large roof overhang that makes up for the lack of exterior cladding.
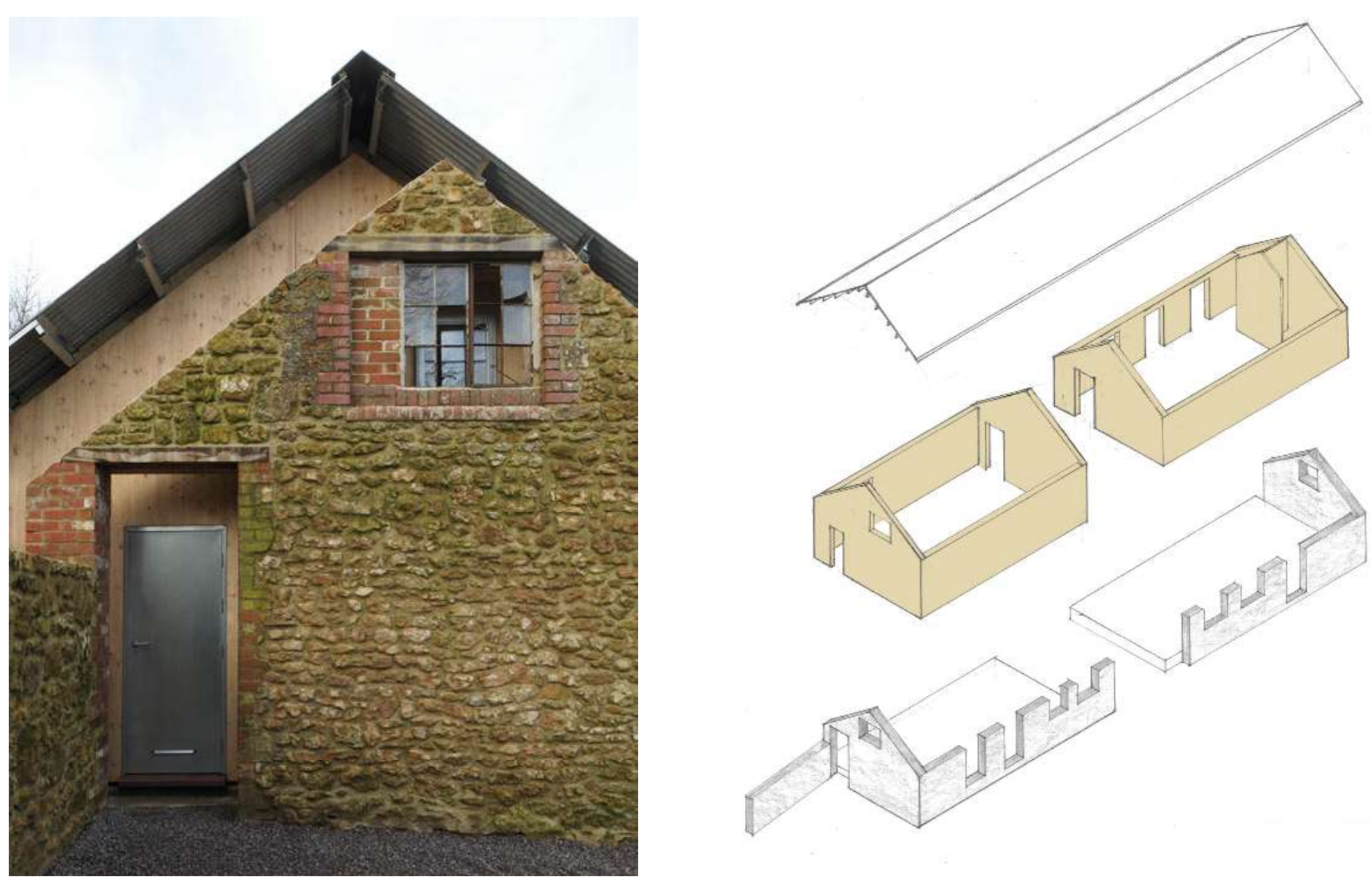


\section{Design Criteria Analysis}

\section{Character}

The form of the new structure respects what was there originally. The roof pitch is raised away from the existing gable to differentiate old and new.

\section{Structure}

Spruce C.L.T walls and roof structure sits on a concrete pad inside the existing structure. U.R.M has not been strengthened.

\section{Heritage}

The barn required remedial work, dilapidated walls and roof were removed and the remaining walls stabilised and repaired. The new structure was a house inserted within the existing masonry walls.

\section{Envelope}

C.L.T addition inserted inside the existing masonry walls. Where there are openings in the masonry, there is a solid C.L.T wall behind highlighting the buildings new use and showcasing the C.L.T from the exterior. $300 \mathrm{~mm}$ thick panels provide insulation and thermal mass.

\section{Programme}

Designated archive and office space are enabled by the enclosure that the C.L.T provides. Solid walls means that electrical connections and wiring is exposed and fixed directly to interior walls.
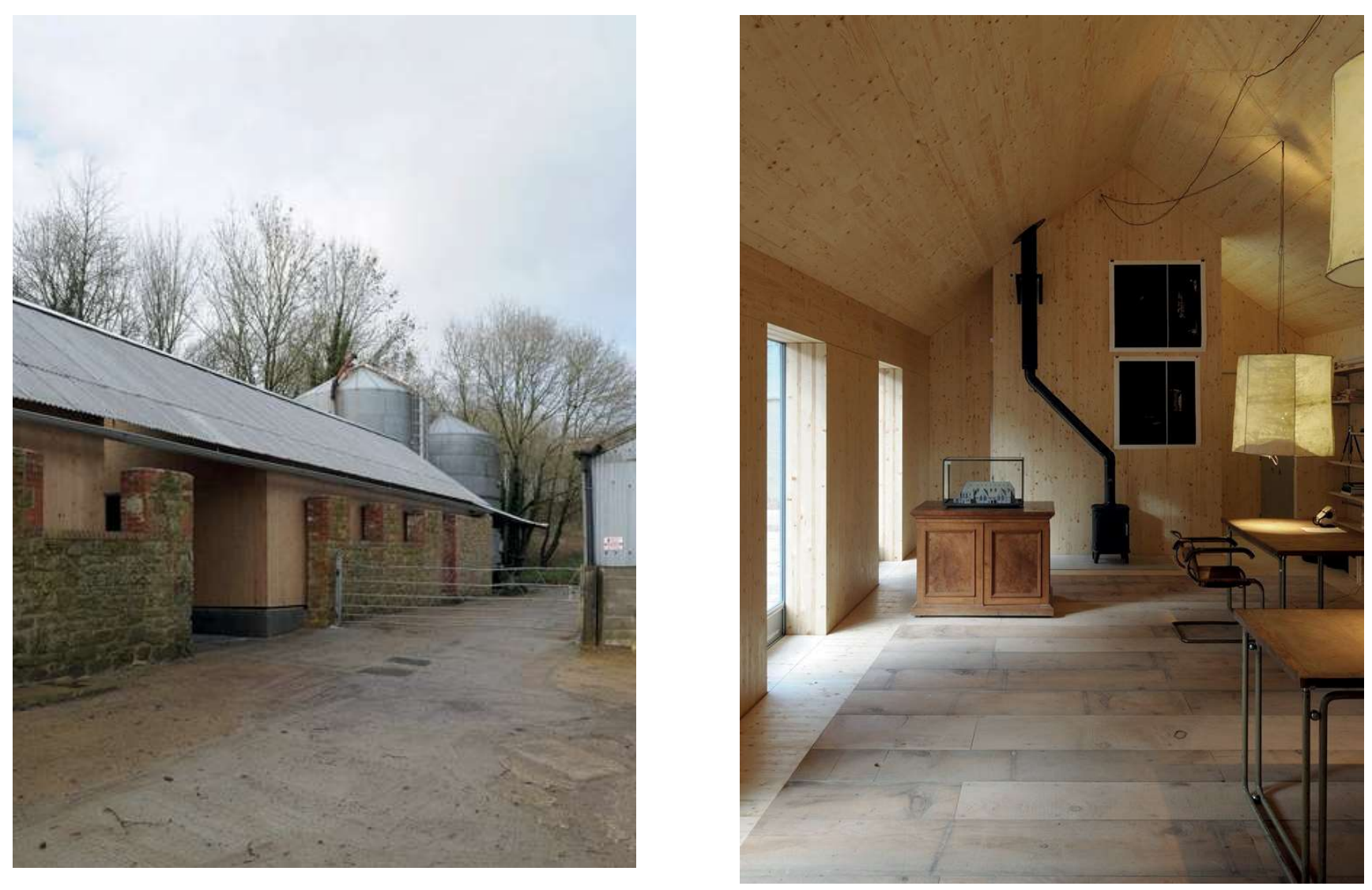

Figure 113 New C.L.T is visible through existing U.R.M masonry.

Source: James Pallister
Figure 114 Architecture Archive interior. Source: James Pallister 


\subsection{Iteration 1: Precedent Analysis}

\subsubsection{Large Precedent}

Name: Inujima Seirensho Art Museum

Location: Inujima, Japan

Architect: Hiroshi Sambuichi

Constructed: 1909

Date of re-use: 2008

Former use: Copper refinery

New use: Gallery, museum, heritage site

Key Features: Adaptive reuse, heritage, large master plan.

Key design strategy: Treatment of large industrial site.

Located on Inujima Island, off the mainland of Japan, an art museum and gallery have been created within the remains of a former copper refinery.

The heritage of the site is acknowledged and celebrated in the architects revitalisation of the site. Material sourced from the remains of the site have been incorporated into the buildings adaptive reuse.

A small portion of the site has been developed for use as the Art Museum. As the complex is very large, some areas have been left in ruins, which acknowledges the heritage and former use of the site.

Only one building in the site is constructed from materials foreign to the existing site. An angular glass box with glulam portals that invites visitors underground.
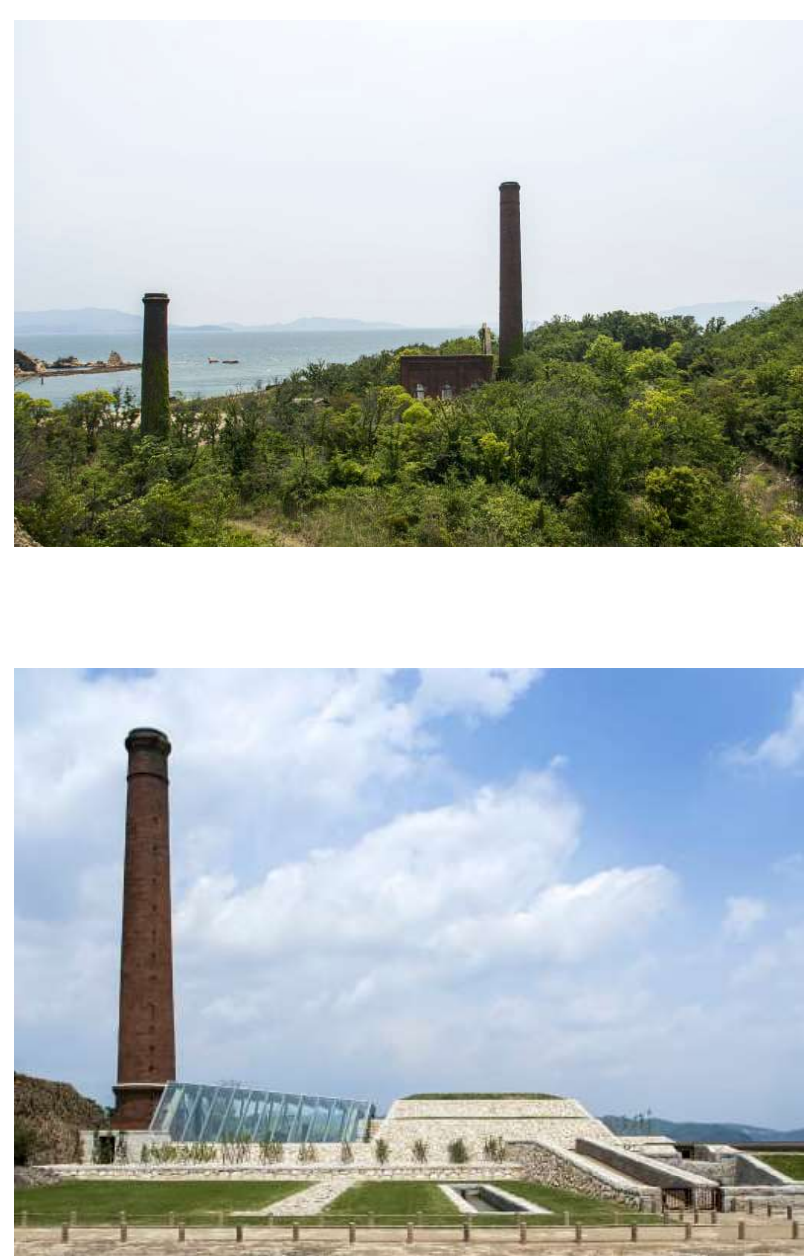

Figure 115 Former copper refinery on Inujima Island. Source: Alessio Guarino

Figure 116 Adaptive reuse contrasts old and new materials. Source: Alessio Guarino.

\section{Design Criteria Analysis}

\section{Character}

The new addition is humble in size, but clearly contrasting in materials so that new and old are explicitly separated.

\section{Structure}

Angled Glulam portal frames are expressed through glass curtain walls. Visibly very striking.

\section{Heritage}

The scale of the site allows the heritage to be expressed. The new component is relatively small compared to the overall master plan.

\section{Envelope}

Transparent glass walls are placed next to masonry walls providing a stark contrast between the materials.

\section{Programme}

The glass entrance brings light into the building, allowing people to enter the museum located underground. 

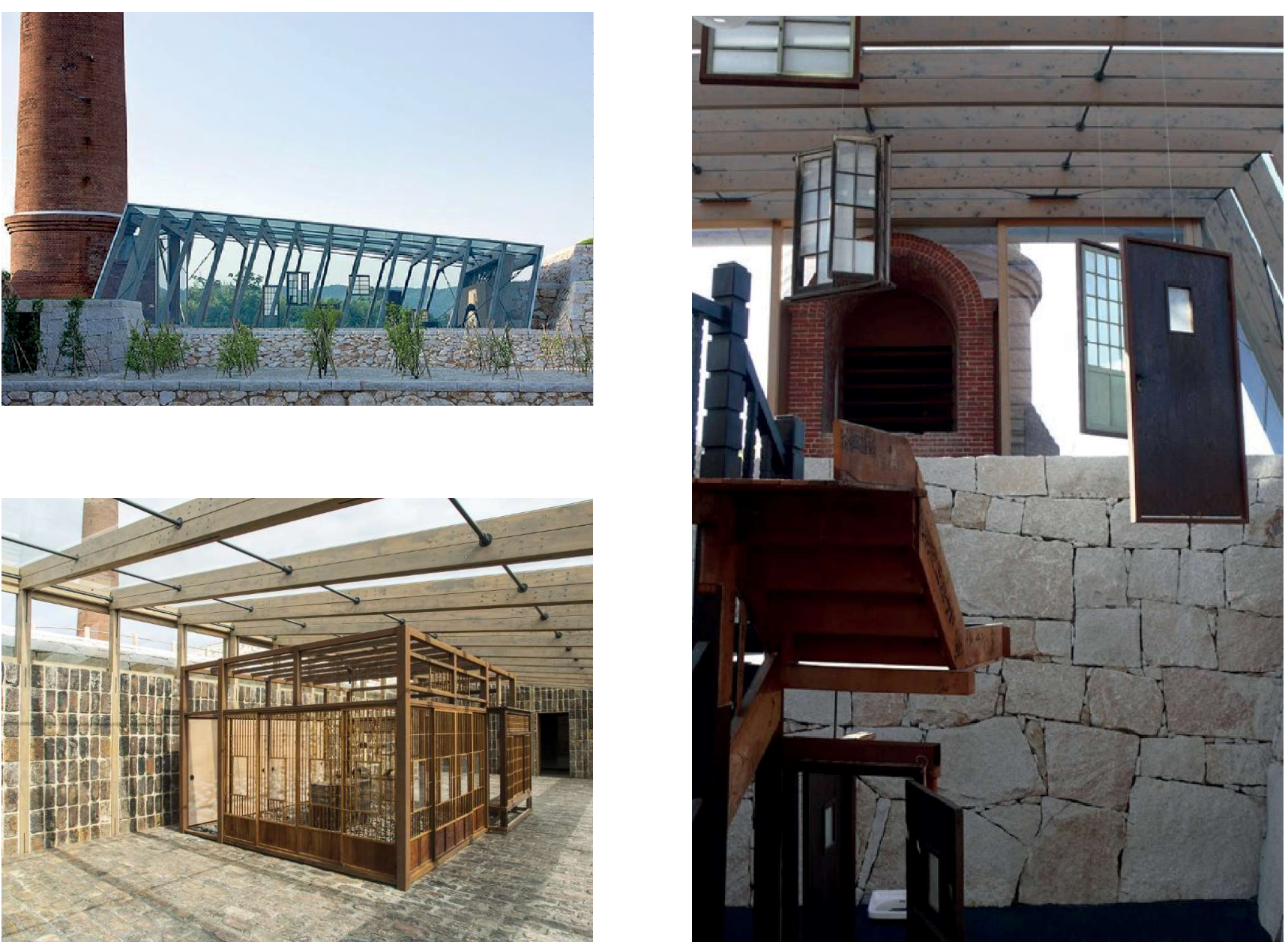

\subsubsection{Iteration 1 Reflection}

Iteration 1 has analysed three adaptive reuse precedents of different scales. The response to the site context and the treatment of the existing building was critical to all the precedents.

Each design response in each precedent could be considered humble and respectful to the existing buildings.

Masonry and laminated timber can be used in a way that is complementary to each other in the sense that it allows a building to combine past and present. Masonry, which represents the existing heritage, is heavy, in-situ and permanent. This contrasts the laminated timber, a lighter new material. Laminated timber enables a new program to occur, its impermanence and delicacy allows the heritage significance of the site to be carried forward.

In all of the precedents, the changes were reversible. This acknowledges that heritage sites evolve through time, and ultimately allows new interpretations of the heritage site to occur in the future. Laminated timber is a material that allows reversible changes in the future. 


\subsection{Iteration 2: Identify Design Strategies}

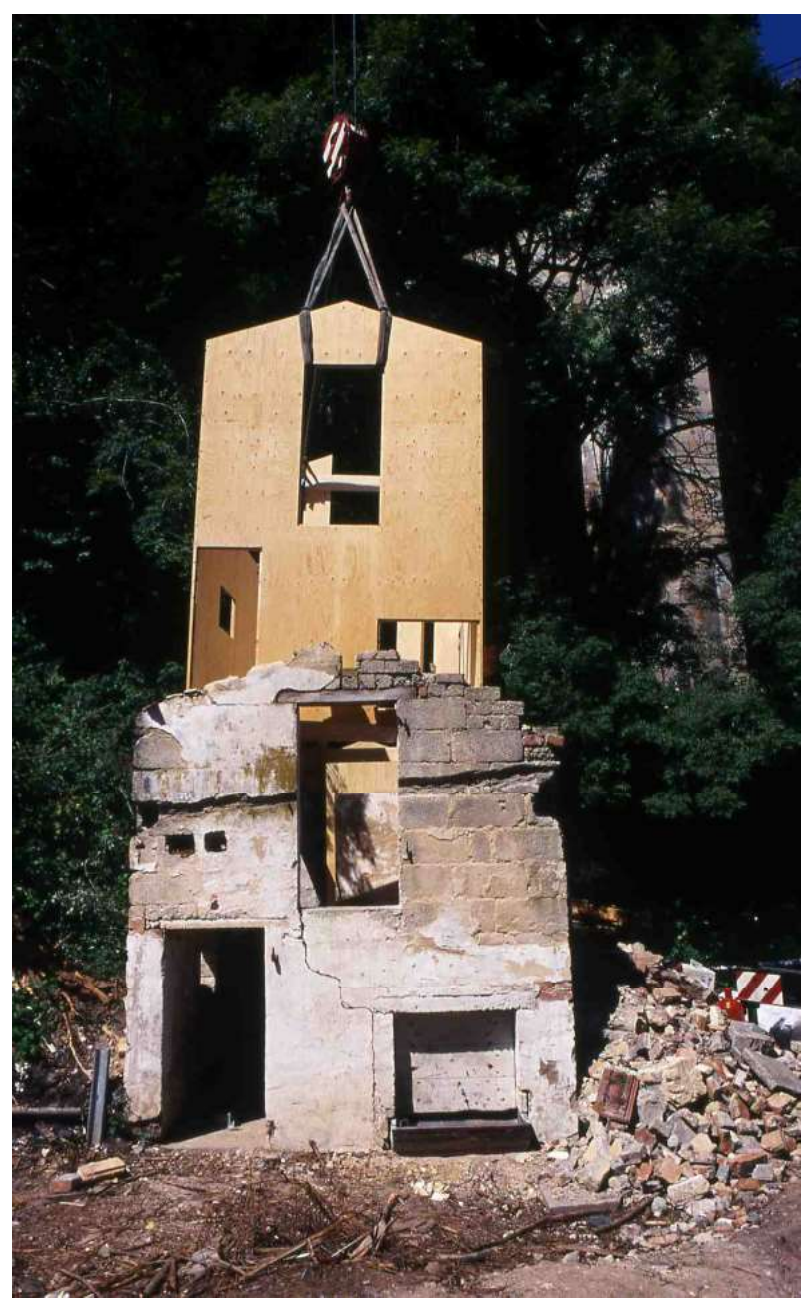

Figure 120 L.V.L insertion into existing masonry shell. Source: Zooey Braun

5.3.1 Design Strategies (Small Precedent)

\section{Light From Above}

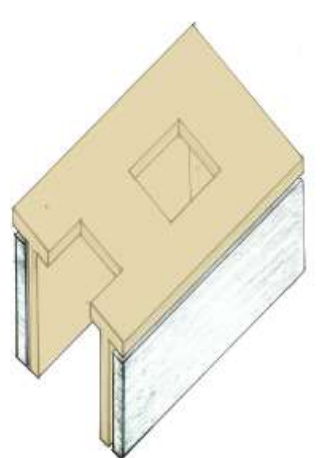

Figure 121 Where there was an absence of openings at the rear of the building a skylight was used to bring light into the building.

Source: Author's Image

\section{Aligned Openings}

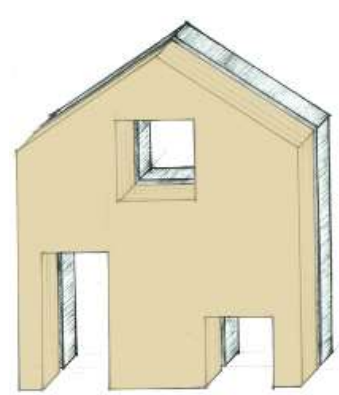

Figure 122 Existing openings in masonry are aligned with openings in the laminated timber to allow permeability. Source: Author's Image

\section{Aligned Walls}

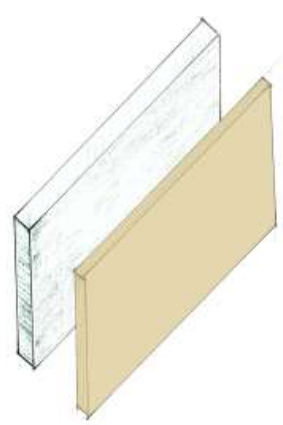

Figure 123 Laminated timber walls are in parallel with existing masonry walls.

Source: Author's Image

\section{Flooring}

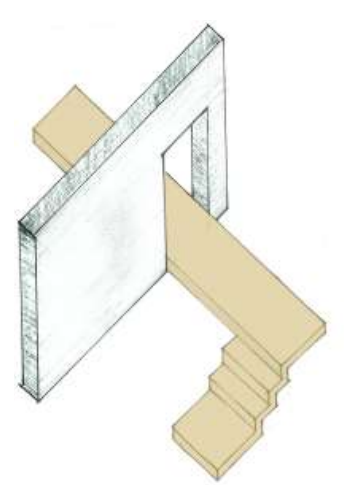

Figure 124 Unlike other materials, laminated timber as a material can be used as floor roof and walls.

Source: Author's Image 


\section{Insertion}

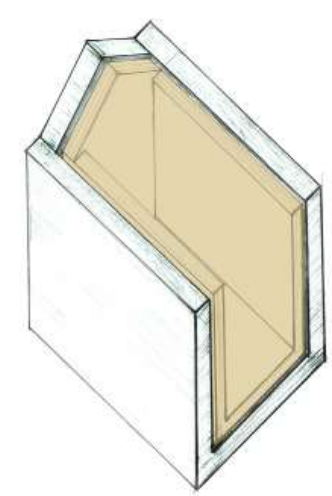

Figure 125 Laminated timber is inserted within existing masonry footprint.

Source: Author's Image

\section{Corner Detail}

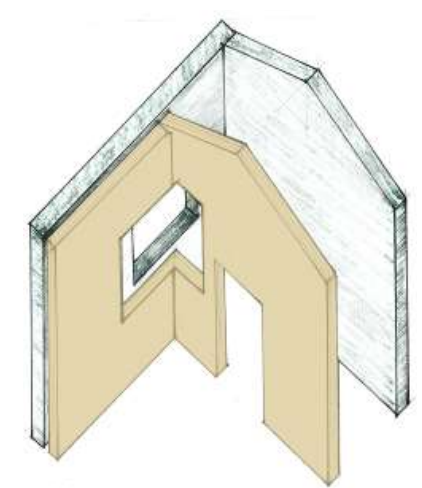

Figure 126 Laminated timber detail transforms existing space.

Source: Author's Image

\section{Visible Masonry}

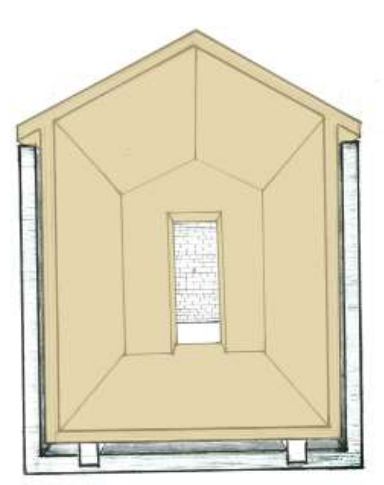

Figure 127 Interior is almost entirely laminated timber (roof, walls, floor), apart from the back wall in which masonry is exposed. 


\subsection{Iteration 2: Identify Design Strategies}

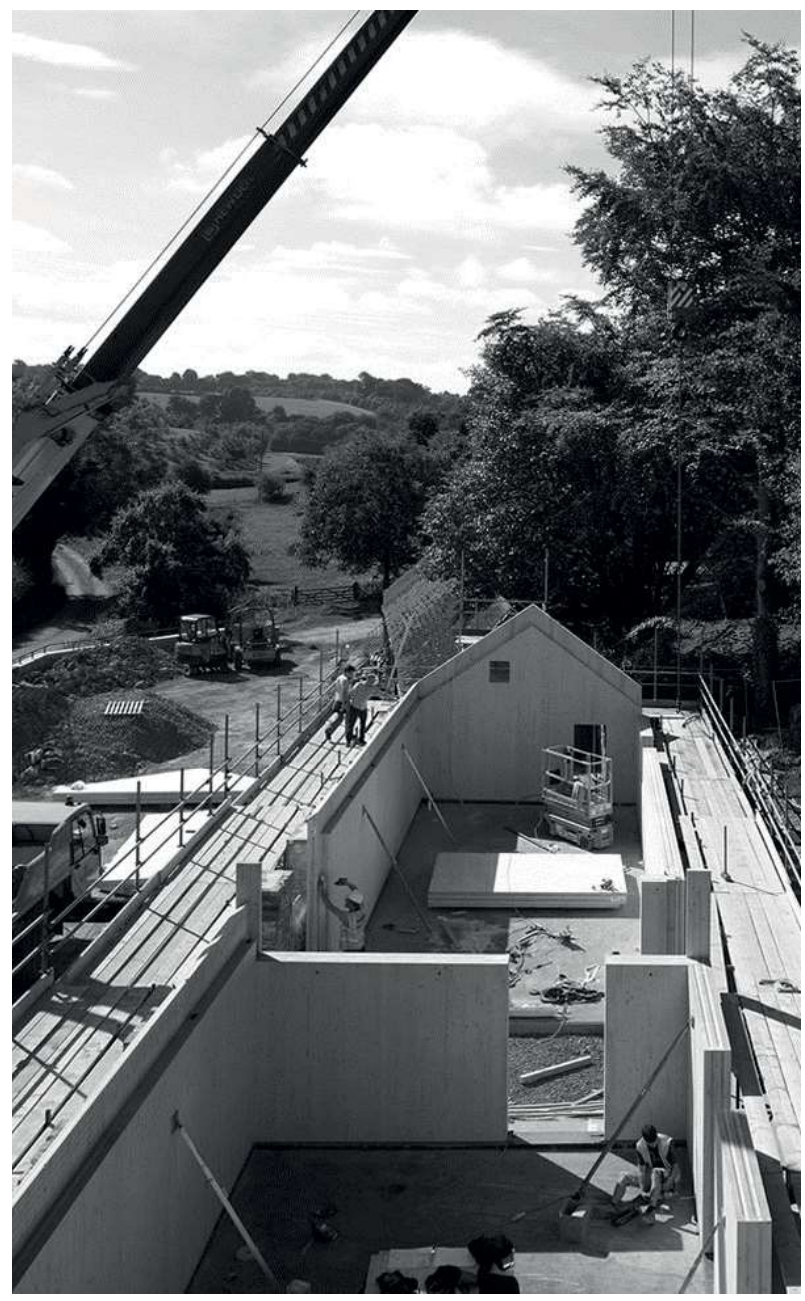

Figure 128 Architecture Archive. Source: James Pallister
5.3.2 Design Strategies (Medium Precedent)

8. Half Height Masonry

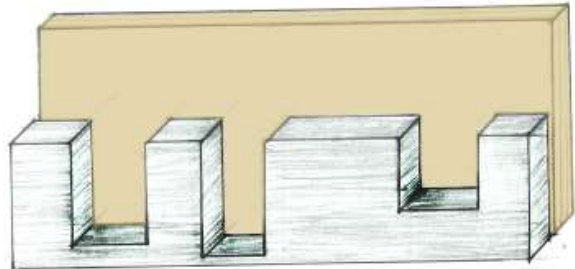

Figure 129 Full height C.L.T walls are used behind half height masonry remains.

Source: Author's Image

9. Offset Window

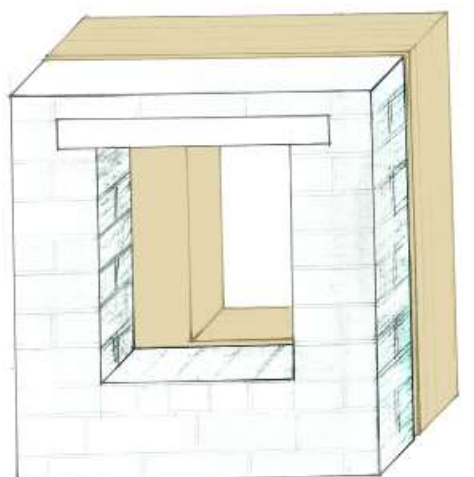

Figure 130 Existing window openings are offset from new C.L.T openings.

Source: Author's Image
10. Restoration

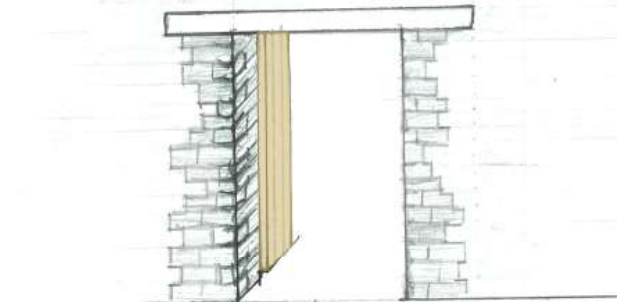

Figure 131 Masonry openings have been restored. Source: Author's Image

11. Concealed Openings

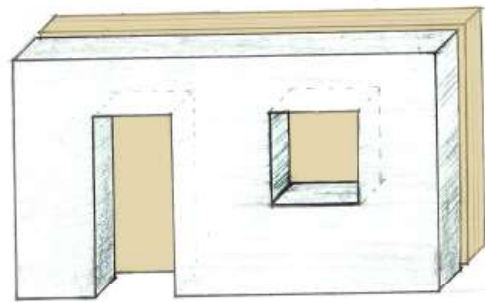

Figure 132 C.L.T walls cover up existing openings in the masonry.

Source: Author's Image 


\section{Masonry in Ruins}

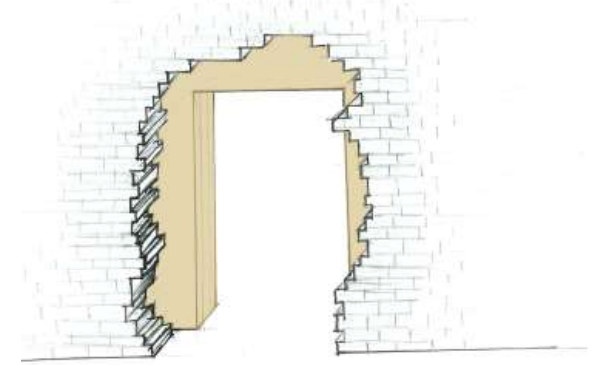

Figure 133 Masonry openings have been left in ruins, with laminated timber visible through the openings.

Source: Author's Image

\section{Offset Roof Pitch}

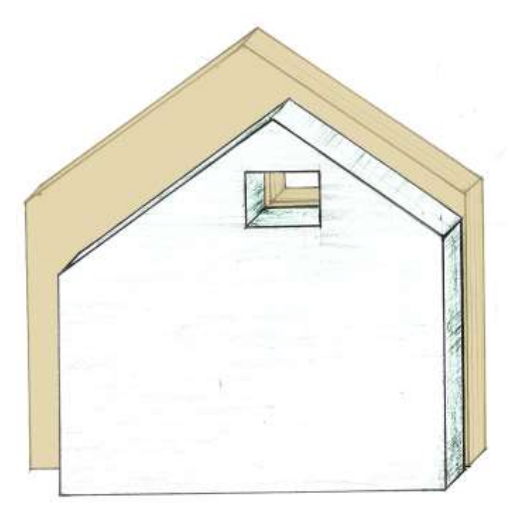

Figure 134 New roof pitch is off set from original masonry gable.

Source: Author's Image
14. Offset Opening

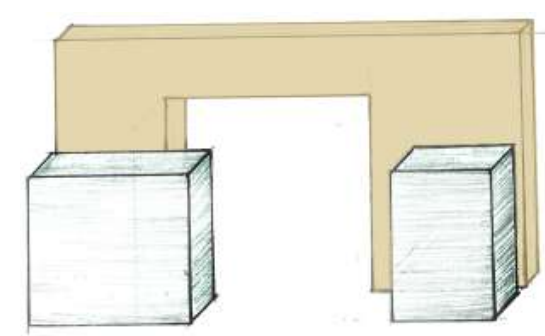

Figure 135 Existing door openings are offset from new C.L.T openings.

Source: Author's Image 


\subsection{Iteration 2: Identify Design Strategies}

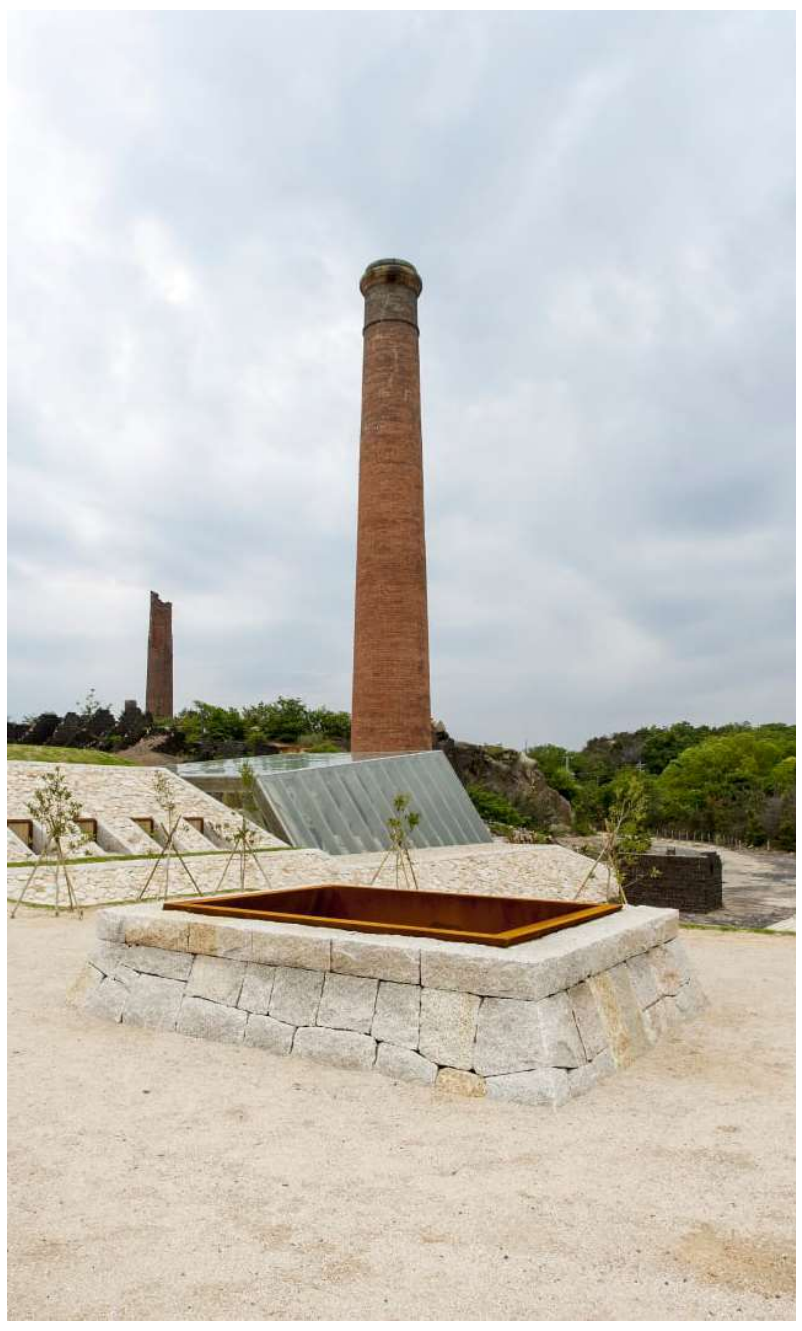

Figure 136 Inujima Seirensho Art Museum. Source: Alessio Guarino.
5.3.3 Design Strategies (Large Precedent)

15. Light Material above Heavy Material

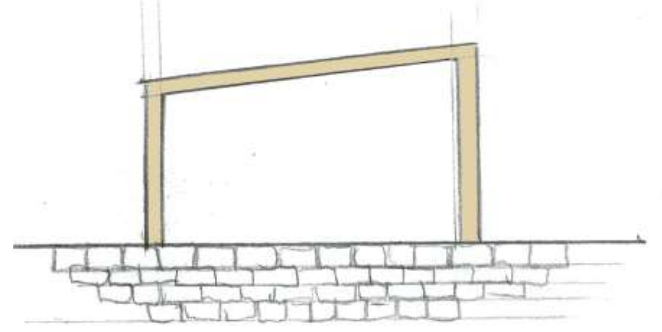

Figure 137 New light material (laminated timber) used on top of existing heavy material (masonry).

Source: Author's Image

\section{New Addition}

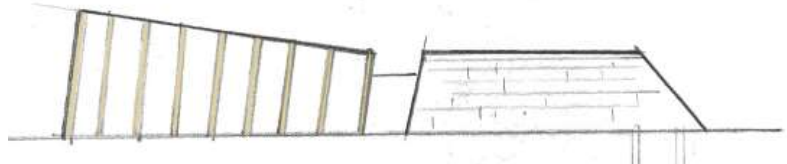

Figure 138 Old and new materials are both celebrated through the design. Source: Author's Image

\section{Laminated Timber as Structure}

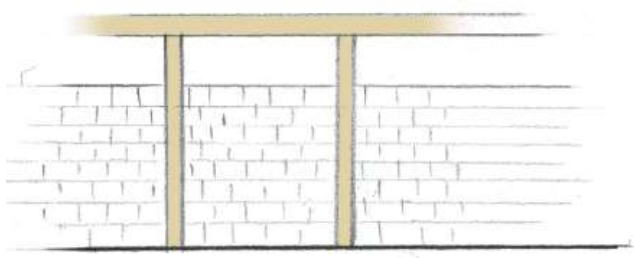

Figure 139 Structural laminated timber is expressed in the design.

Source: Author's Image

\section{Change of floor height}

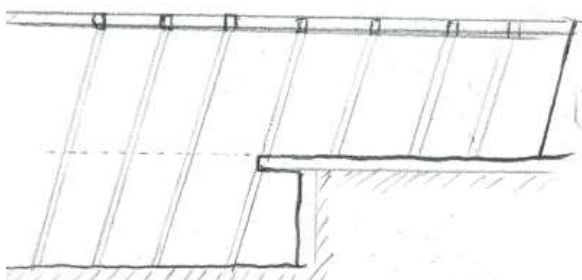

Figure 140 Change of floor height is introduced allowing the programme to be integrated within the industria heritage site.

Source: Author's Image 


\section{Portion of Site Used}

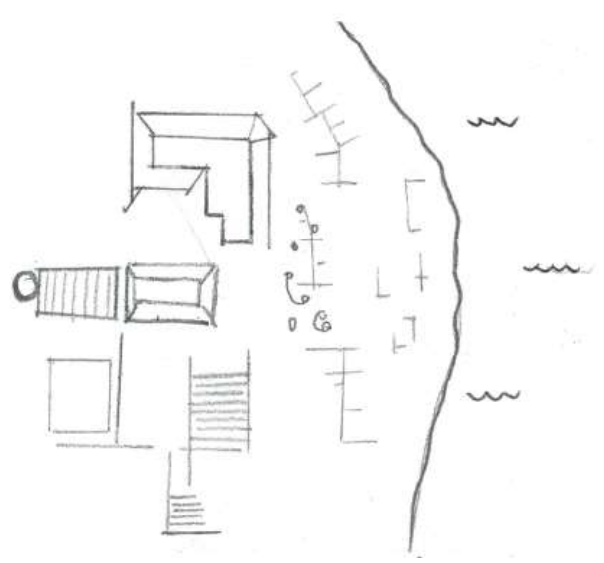

Figure 141 As a large site, only a portion is used for adaptive reuse, the rest remains as industrial heritage left in ruins.

Source: Author's Image

\section{Introduce New Geometry}

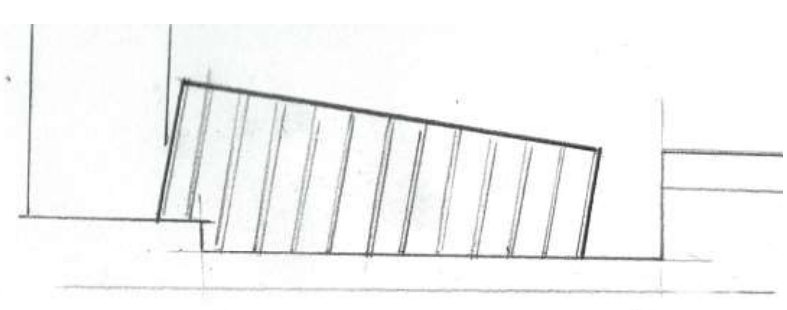

Figure 142 Geometry is introduced to differentiate old and new materials.

Source: Author's Image

\subsubsection{Iteration 2 Reflection}

20 design strategies that use laminated timber and masonry through adaptive reuse were derived from the precedents.

While the specific material relationship between laminated timber and masonry is important, it became clear that how these materials were used within the site to achieve adaptive reuse also contributed.

Overall, masonry exteriors are generally preserved to retain the existing relationship with the site.

Laminated timber is visible from the exterior, but is secondary to the masonry. This hints at a new programme occurring within the heritage site.

The design outcomes of the adaptive reuse precedents include many opposing relationships between laminated timber and masonry:

- old - new

- exterior - interior

- heavy - light

- permanent -impermanent 


\subsection{Iteration 3: Initial Design Strategy Application}

\subsubsection{Analysis}

As an initial test, design strategies identified from precedents (iteration 2) were explored using site-less abstract models. This design test aimed to explore the relationship between masonry and laminated timber in its simplest form.

4 typical buildings scenarios were tested. It was immediately apparent that there are multiple ways that laminated timber approach the existing masonry within each scenario. The application of laminated timber to masonry vastly effects outcome experienced within a space.

\subsubsection{Iteration 3 Reflection}

A relationship forms between the two materials:

- Existing masonry acts as 'heavy' and laminated timber as 'light' material. Laminated timber is supplementary and less permanent than the existing masonry.

- Masonry and laminated timber are both planar in form, which allows complementary, compatible design exploration.

- Masonry form is typically rectilinear and orthogonal within industrial buildings (unless in a state of ruins), whereas laminated timber allows for angles to be incorporated. Laminated timber provides a welcome deviation from the existing, predictable rectilinear masonry.

- Masonry is only used within industrial heritage for walls. Laminated timber can be used as flooring, walls and roofing. This allows the materials to be tested spatially with one another.

- Successful iterations occur where one material (primary) takes ownership over the other (secondary). There is less success when both materials are 'active' together. Either masonry or laminated timber could be the primary material.

- Successful iterations make use of existing junctions and openings as an opportunity to introduce laminated timber. Laminated timber can also be spaced from masonry to act as a partition and create new space.
5.4.2 Perpendicular Walls
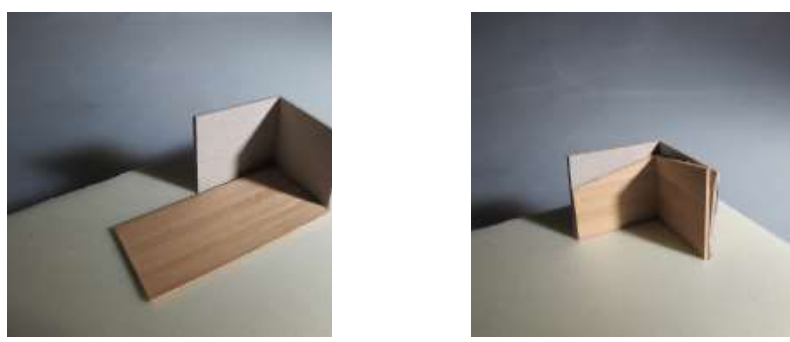

5.4.3 Door Opening
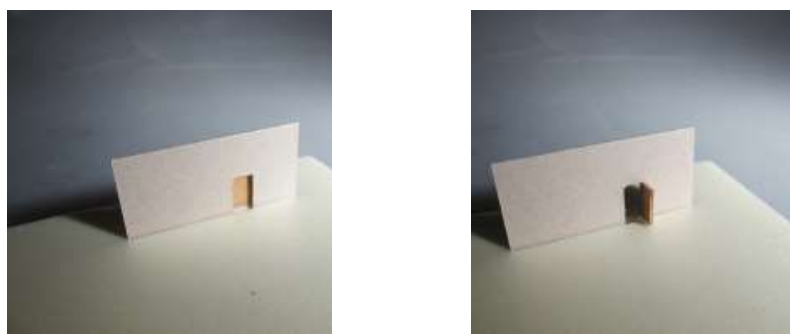

5.4.4 Window Opening
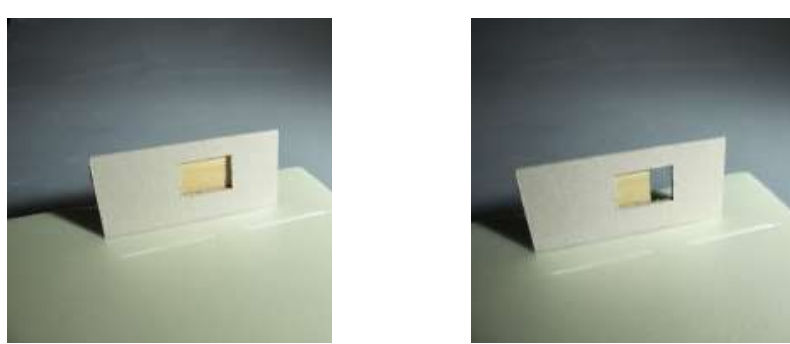

5.4.5 Wall in Ruins
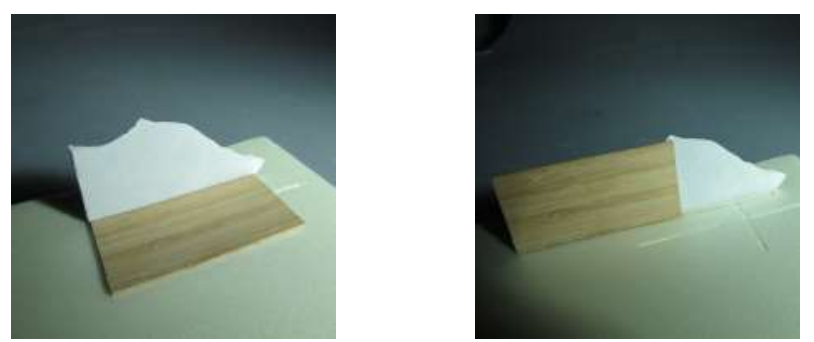

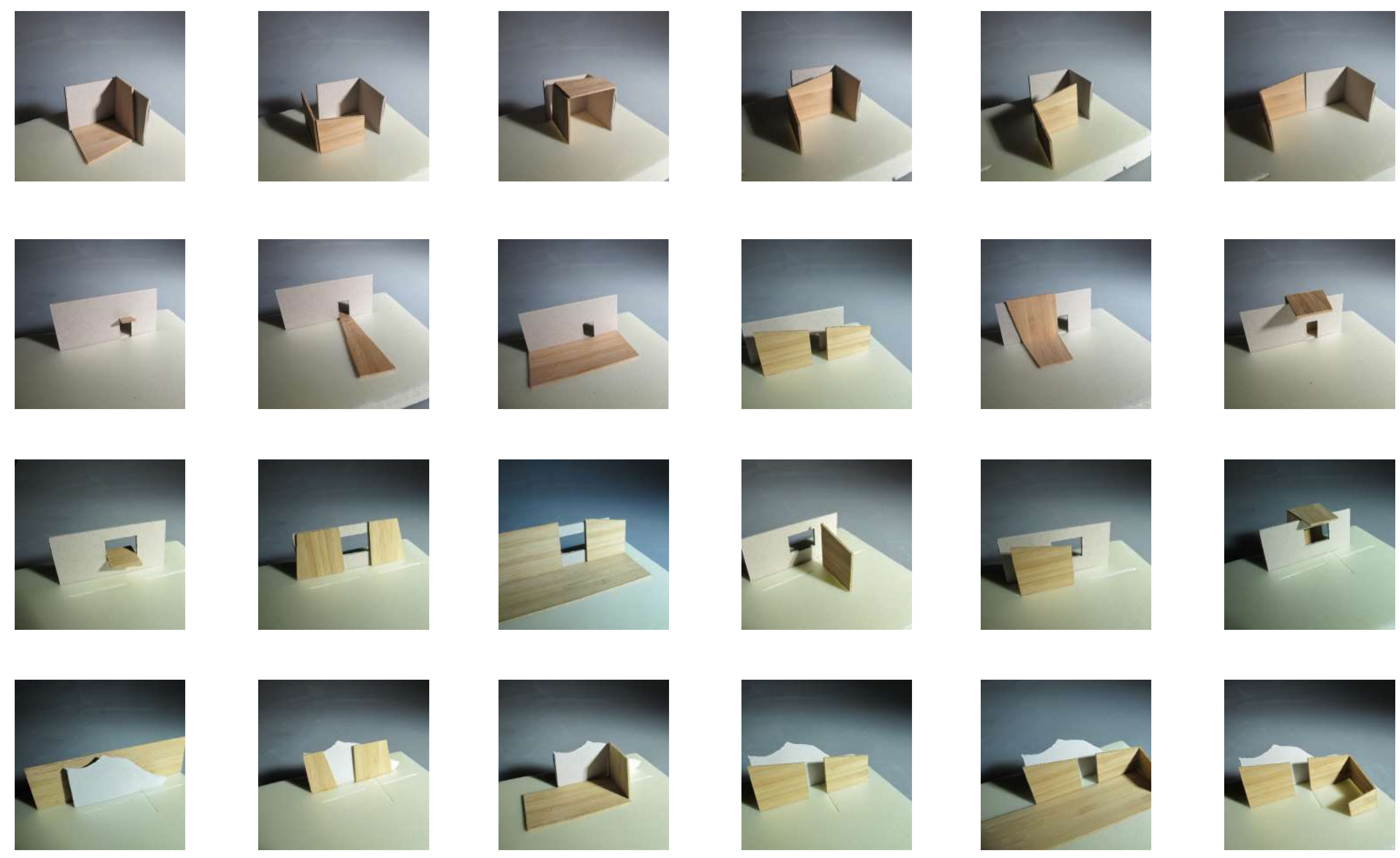


\subsection{Iteration 4: Initial Design Concept}

\subsubsection{Initial Concept}

The research is exploring how laminated timber and U.R.M could be used together within a heritage setting, the initial concept stems from how these two materials can be compatible and differentiated within the selected site.

As an adaptive reuse project, the initial concept stemmed from the original freezing works and how they could be recognised through architectural intervention. As an industrial site, the existing building footprints are rectilinear with perpendicular U.R.M walls. Since the closure of the freezing works, the relationship with the wharf has become disconnected.

Acknowledging the existing, rectilinear U.R.M walls as the first geometry, a second geometry (derived from the wharf) was introduced to the freezing works. This second geometry could be used as a basis to introduce laminated timber to the site.

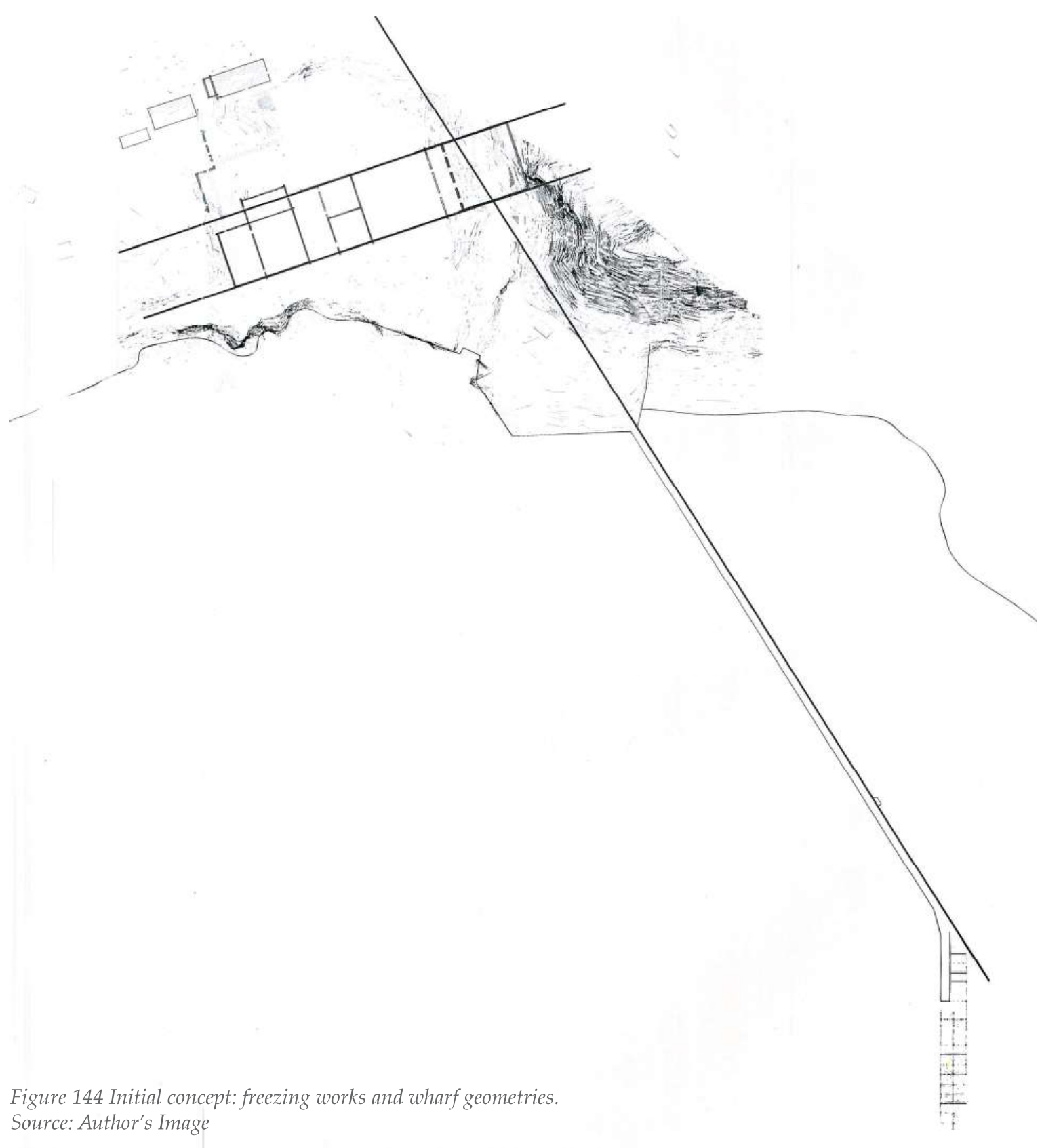




\subsubsection{Concept Reflection}

The introduced geometry (bottom right) is too forced and dominates the existing U.R.M buildings.

The old (U.R.M) and new (laminated timber) should combine in a way that they are complimentary, rather than one material dominating over the other.

A more humble approach of this geometry would be better suited to this site, allowing the industrial heritage significance to be expressed.

This new geometry and the relationship that is created between U.R.M and laminated timber needs to occur at a range of scales, so that the whole project is cohesive:

- Master plan scale

Overall relationship between U.R.M and laminated timber from a wider perspective, addressing the compatibility of new and old buildings.

- Human Scale

Addresses intermediate relationship, how materials respond to specific spaces within the design.

- Detail Scale

Explores the transitional junctions between U.R.M and laminated timber at a small scale.

[design principle 1c]

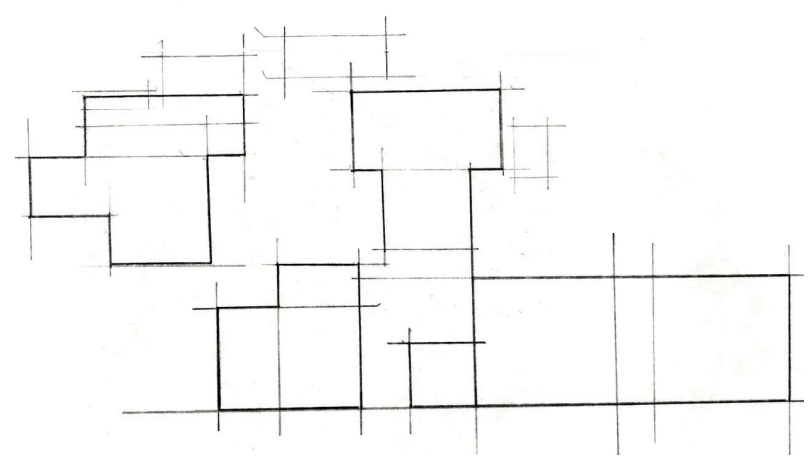

Figure 145 Existing rectilinear building footprints of Tokomaru Bay Freezing Works.

Source: Author's Image

Figure 146 New laminated timber geometry laid over U.R.M geometry.

Source: Author's Image 


\subsection{Iteration 4: Initial Design Concept}

\subsubsection{Possible Factory Locations}

The Tokomaru Bay Freezing Works site is very large, and only a portion required for the honey factory $(800-1000 \mathrm{~m} 2)$. For further development to occur the location of the factory needs to be selected, which will enable design strategies to be developed on a specific building.

Each of the possible locations were analysed against 6 factors.

\subsubsection{Factory Location Considerations}

1. Condition of existing building.

2. Relationship to the street.

3. Relationship within the site context.

4. Does it have suitable U.R.M that is relevant to the research question?

5. Suitability for honey production.

6. Potential for expansion in the future

\subsubsection{Selected Location}

The Manure and Tallow works was selected for the honey factory.

1. Building is in stable condition (although roofs have started to collapse).

2. First building visible from the road.

3. Visible from many viewpoints in Waima Cove, excellent street presence.

4. Single and double storey U.R.M buildings.

5. A range of spaces that can be adapted for honey production facilities.

6. Expansion options in surrounding site. 


\section{Slaughterhouse}

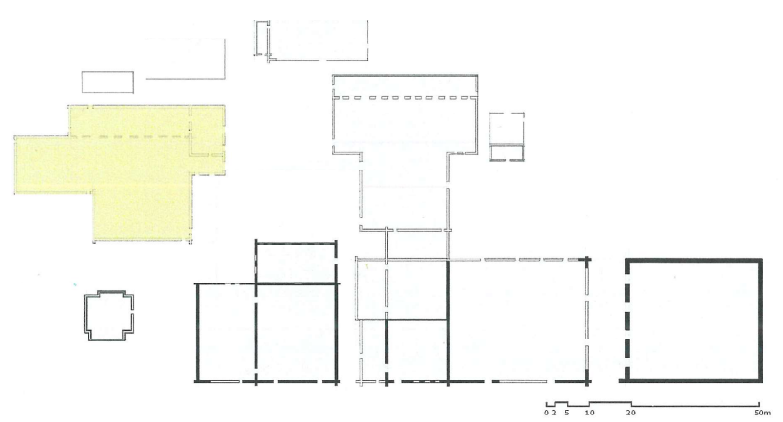

4 Demolished

+ Concrete Pad \& Ring Foundation remains

- Privately Onned (bach packers)

- Remaced from main area of Freezing wolks

- Entrely new build requied.

- Potentral Expasion area.

\section{Engine, Pump and Boiler Rooms}

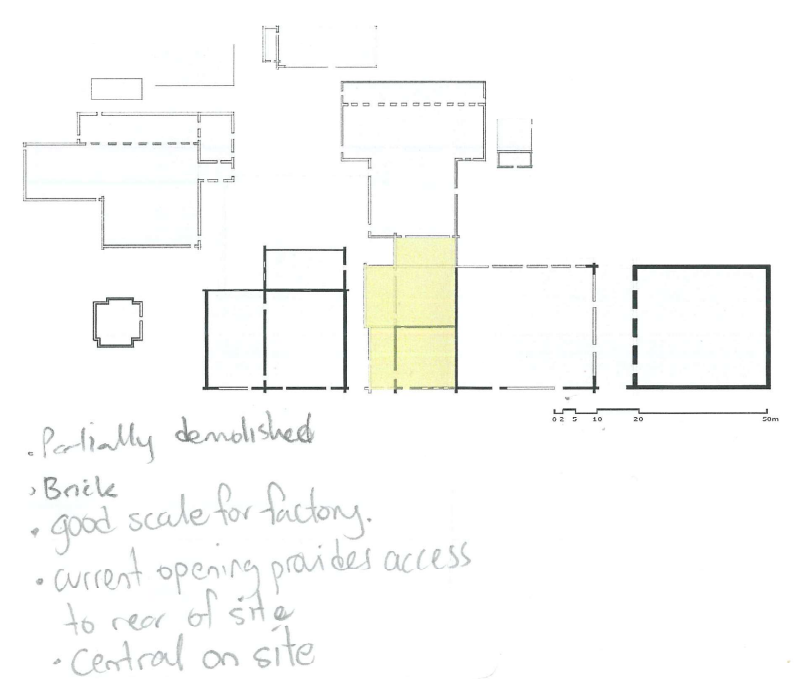

\section{Fellmongery}

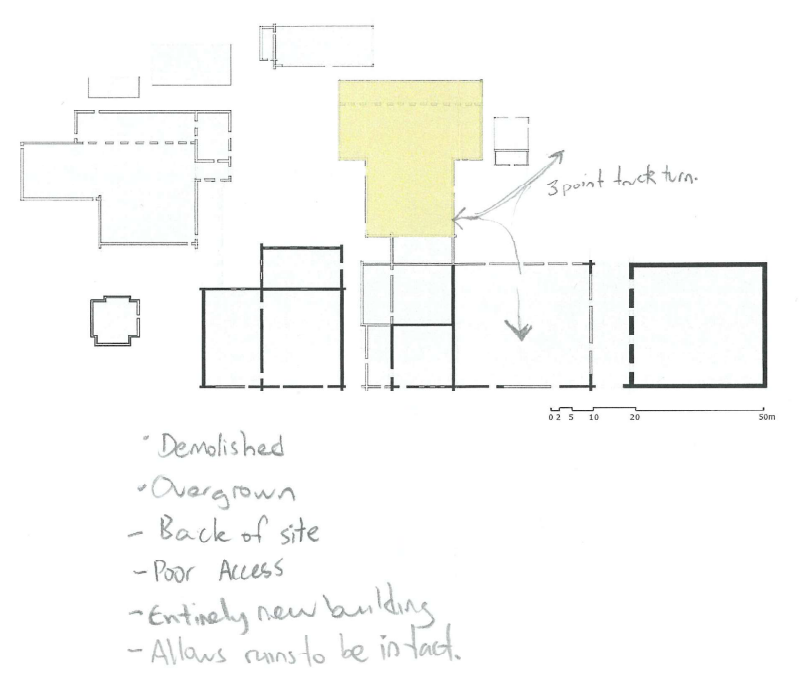

5. Freezing Chamber

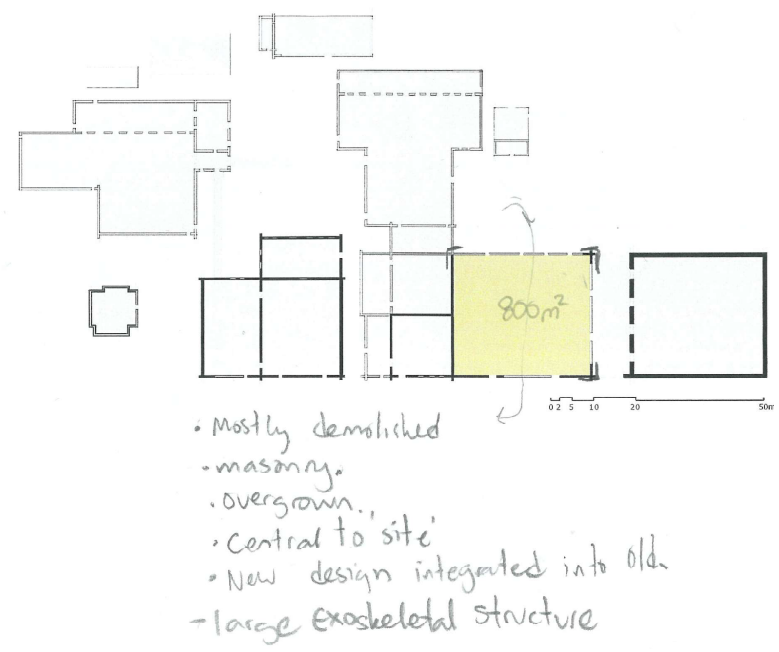

3. Manure and Tallow Works

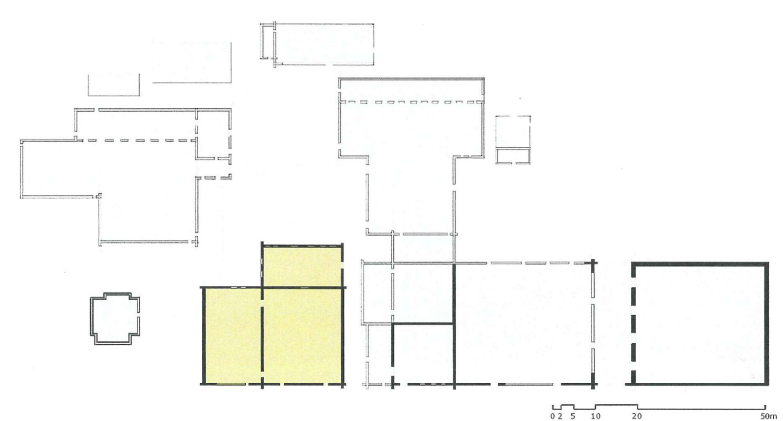

+ Partial roof collapse, mostly intact.

+ Pnvately owned (creyfisherman)

tmost prominent from road, Fust thing to be seen.

the right "scale" for honey factory

t most 'intact' masony building

+ Best response to question, URM/adoptive reuse

\section{Freezing Chamber Extension}

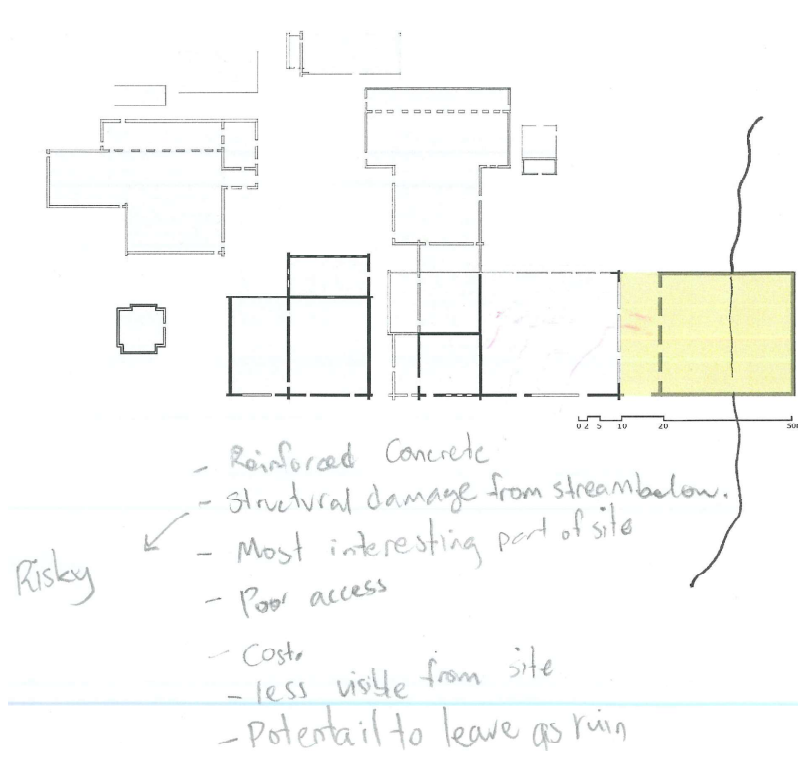




\subsection{Iteration 5: On-Site Strategy Development}

\subsubsection{Application of Strategies On-site}

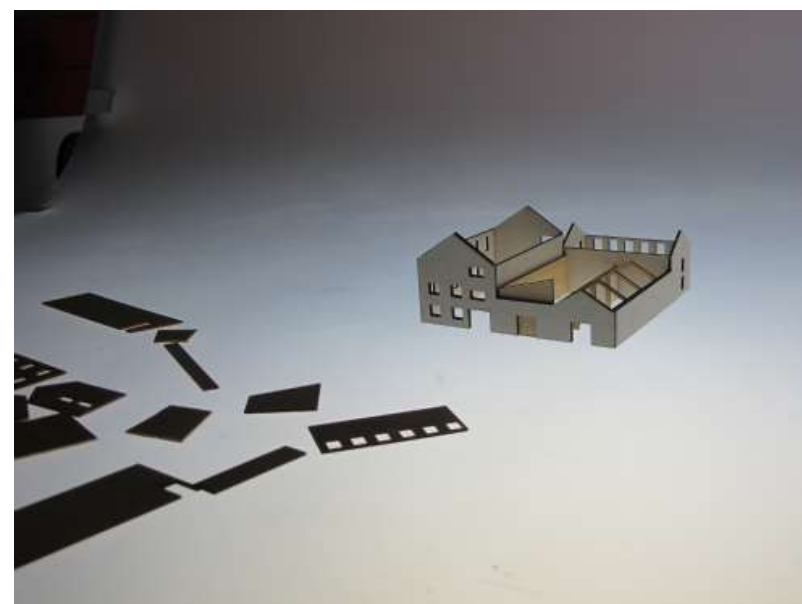

Using the selected building for the honey factory, the former Manure and Tallow works, this design iteration develops the material relationship between laminated timber and masonry using the design strategies identified in iteration 2 .

The building's existing masonry was modeled out of card, and then laminated timber was applied to test design strategies.

\section{Light from Above}

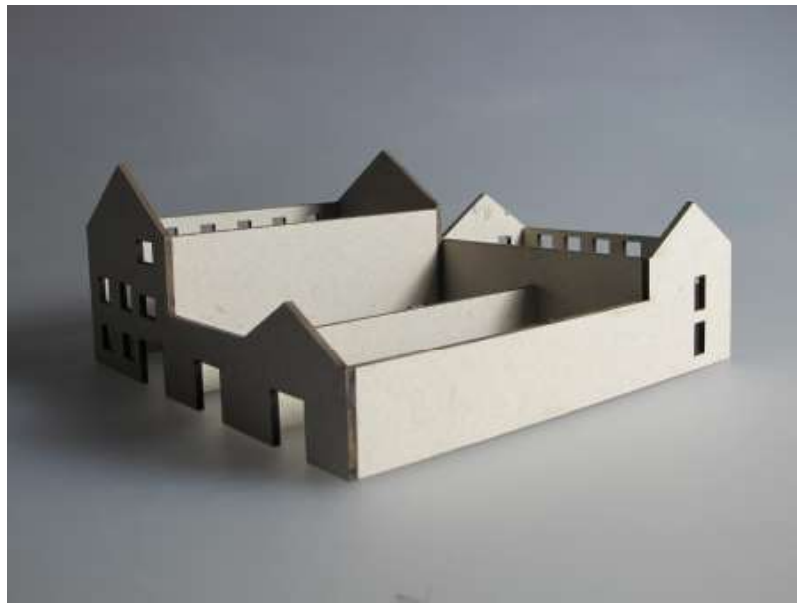

Some areas of the existing building are internal and others have few windows and doors restricting light. Introducing skylights or windows high above can allow daylight into these areas.

[design principle $5 b$ ]

\section{Aligned Openings}

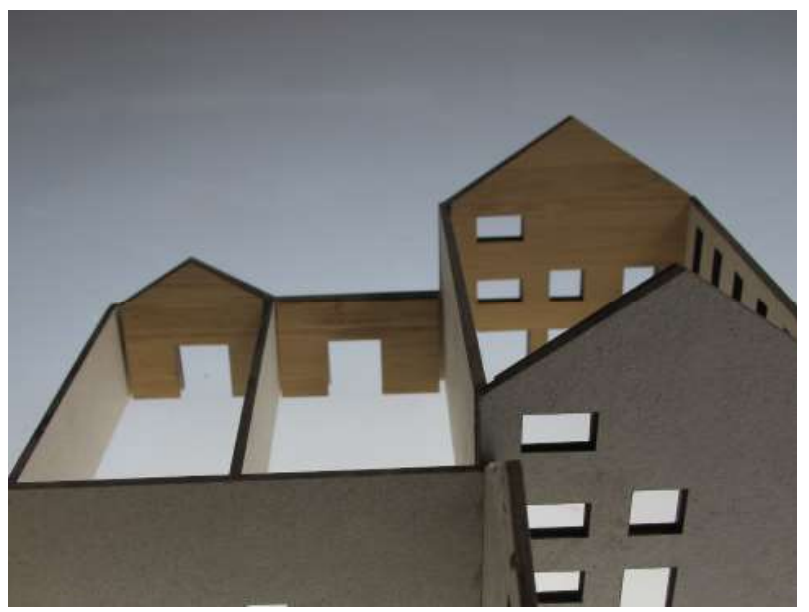

Laminated timber openings are aligned with existing masonry openings to allow maximum permeability between inside and out. [design principle 4d] 


\section{Aligned Walls}

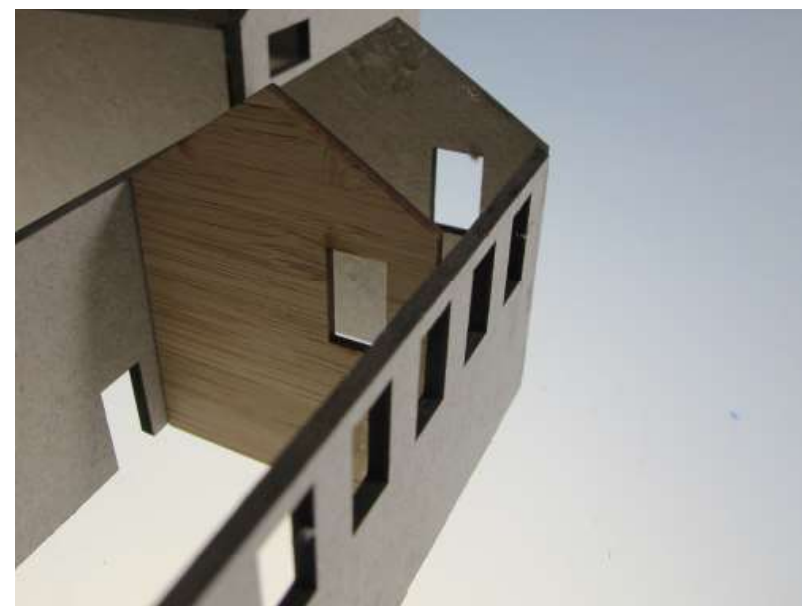

Rather than laminated timber and masonry wall being back to back, the C.L.T wall that replicates the existing masonry wall is set apart to create a usable space between the two materials.

[design principle $3 \mathrm{~d}$ ]

\section{Flooring}

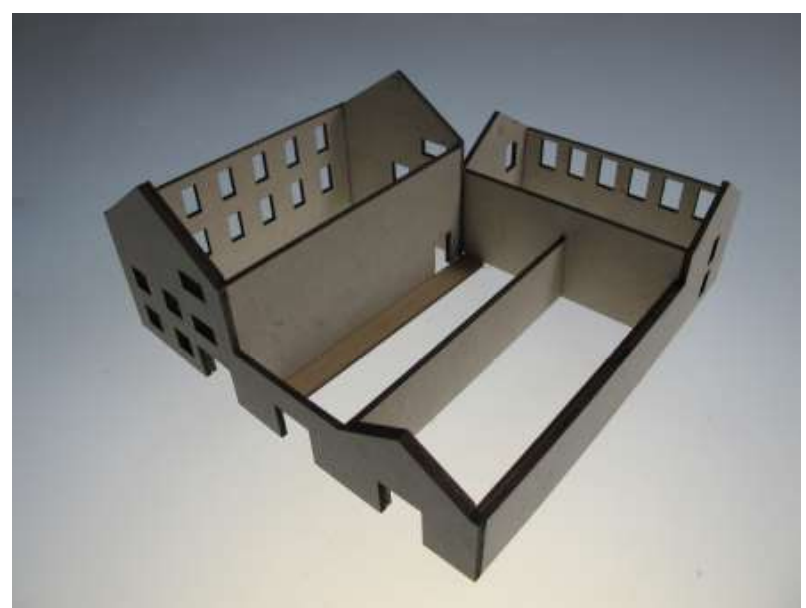

C.L.T can be used on top of existing concrete building footprint to differentiate a public walkway from the honey processing area.

[design principle $5 b$ ]

\section{Insertion}

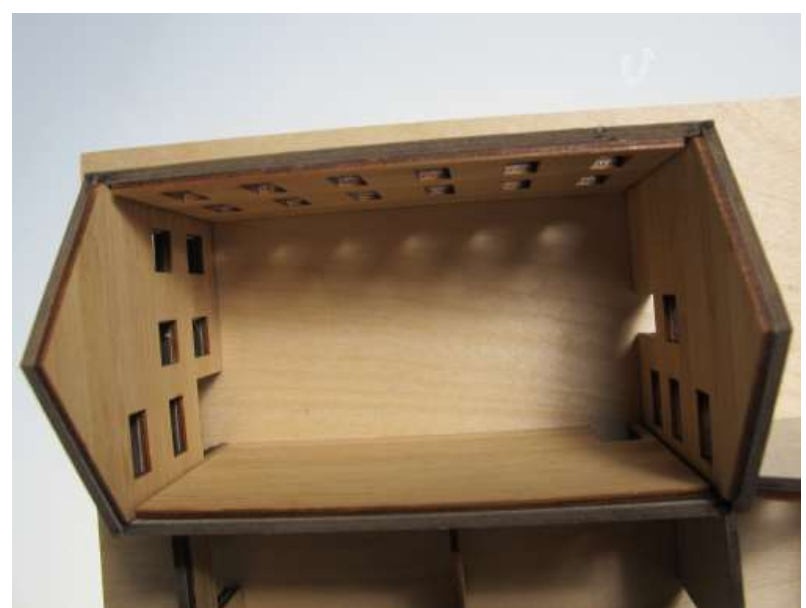

Laminated timber inserted inside provides blank canvas for the new programme. By concealing all masonry from the interior it does not allow connection between old and new. [design principle $4 \mathrm{a}, 5 \mathrm{~b}$ ] 


\subsection{Iteration 5: On-Site Strategy Development}

\section{Visible Masonry}

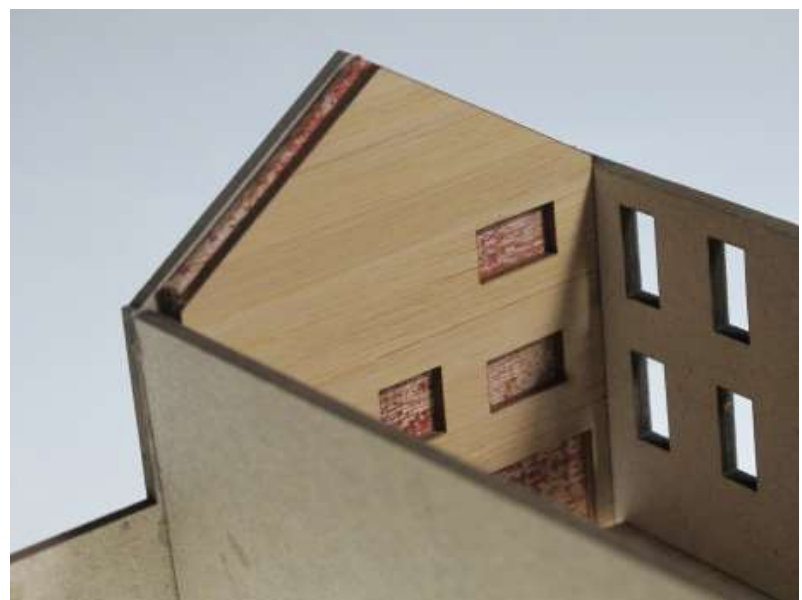

Openings are created through interior C.L.T panel to reveal existing masonry behind. [design principle $3 \mathrm{~d}$ ]

\section{Offset Window Openings}

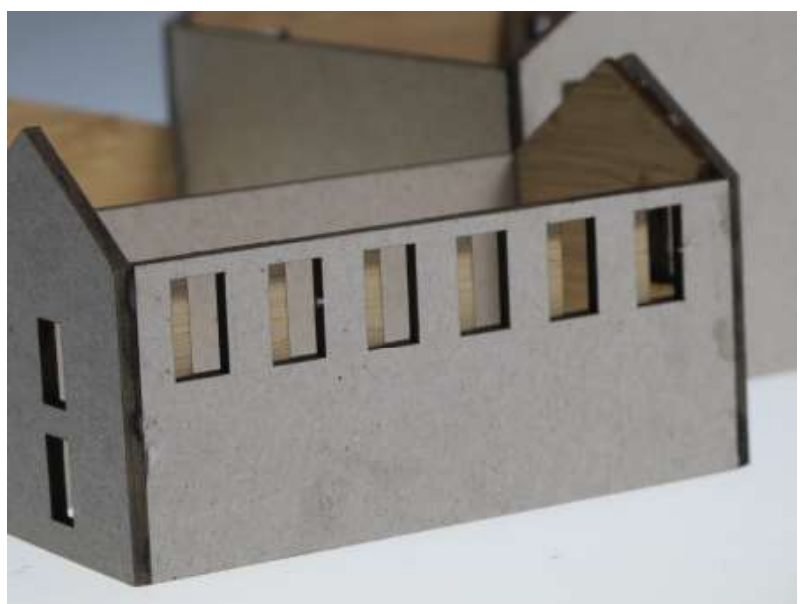

Offset window openings allow laminated timber to be visible from the exterior, which hints at the buildings adaptive reuse. On a small scale this is a delicate detail, on a larger scale it reduces permeability between inside and outside. This is similar to strategy 14 (offset door openings).

[design principle $4 \mathrm{~d}$ ]

\section{Concealed Openings}

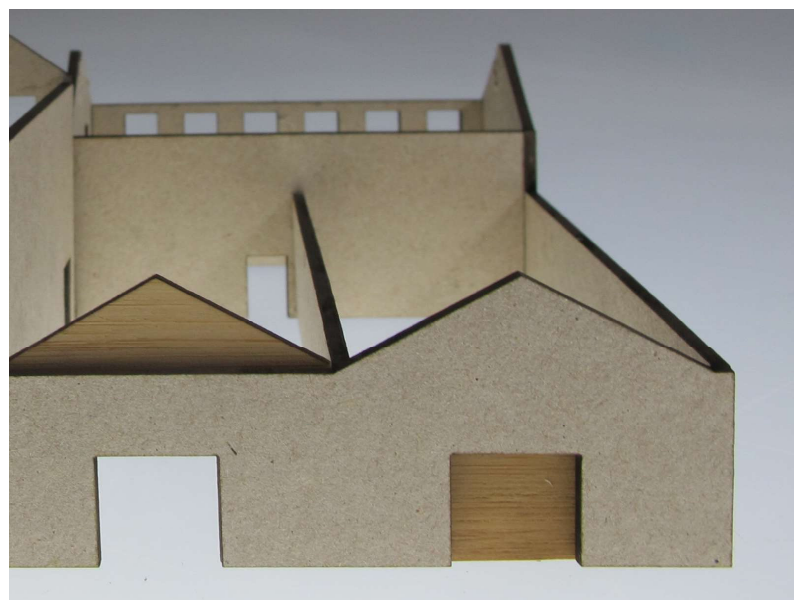

Allows laminated timber to be visible from the exterior of the building, but it does reduce permeability between interior and exterior. As there are limited openings in industrial buildings, it was decided that existing doors and windows should remain to maximize the permeability and allow interaction between inside and out.

[design principle $4 \mathrm{~d}$ ] 


\section{Masonry in Ruins}

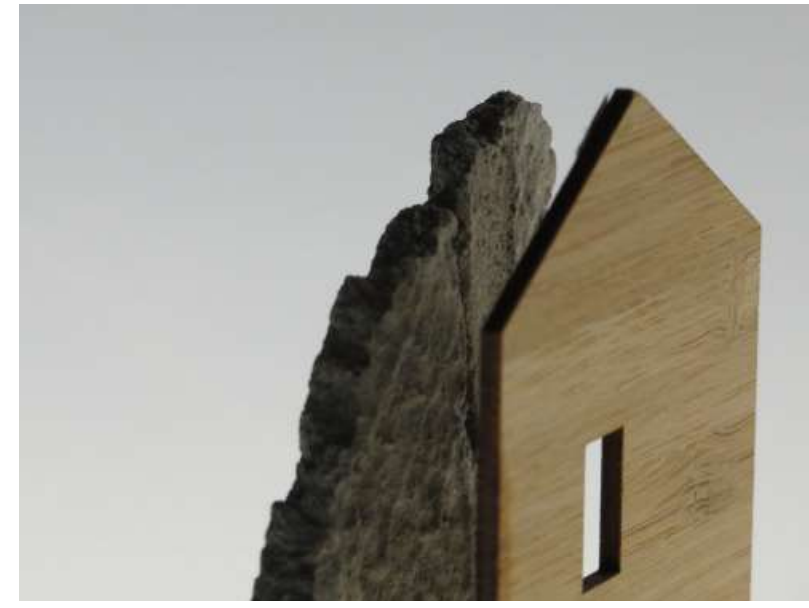

Areas of existing masonry can be left in ruins, to show the historical highs and lows of the site.

[design principle 3d]

\section{Offset Roof Pitch}

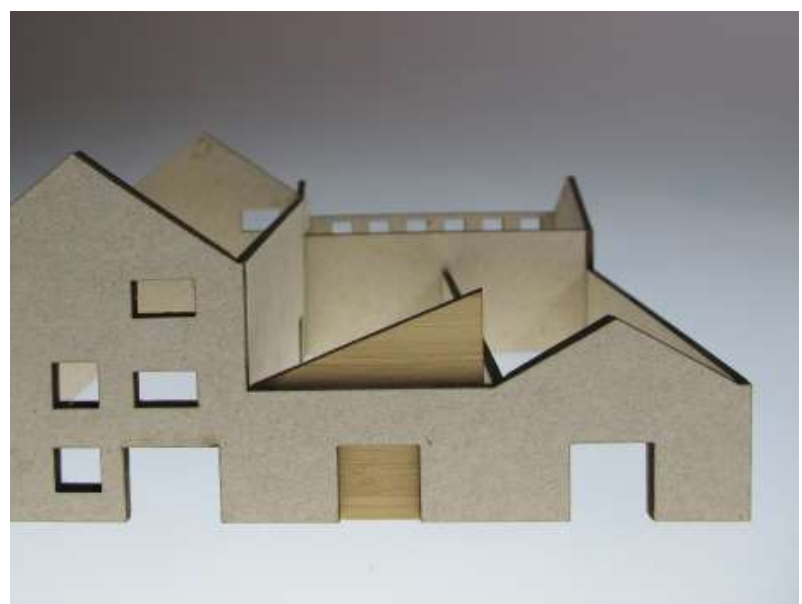

A change in roof pitch to an existing building is introduced to differentiate what is new rather than replicating the original gable that has collapsed. This new geometry helps to create a new identity for the building.

[design principle $1 \mathrm{~b}$ ]

\section{Light above Heavy}

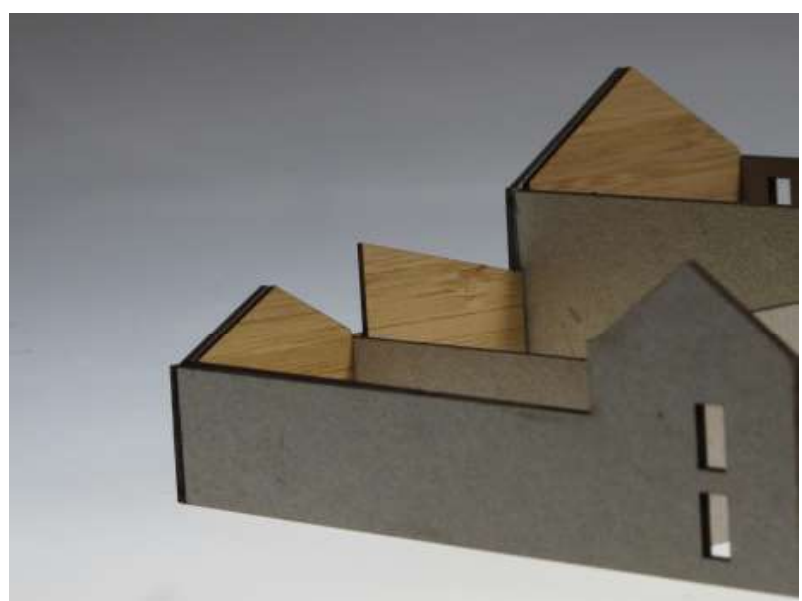

Laminated timber is projected above existing masonry to accentuate the old and new. The introduction of laminated timber to heritage building is reversible, incase change is needed in the future.

[design principle $3 b$ ] 


\subsection{Iteration 5: On-Site Strategy Development}

\section{New Addition}

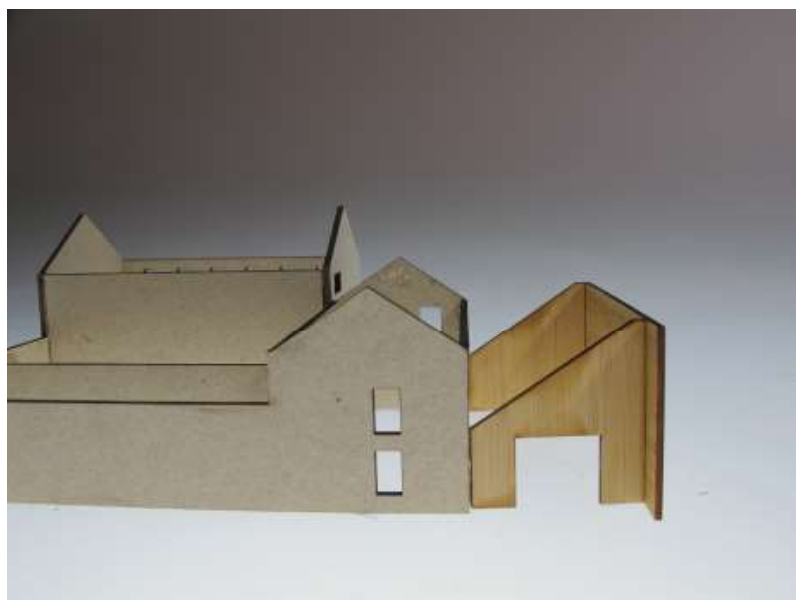

Laminated timber addition is not trying to replicate or blend in with the existing masonry. Clear distinction between new and old is created. The new addition is located at the rear of the site to preserve the masonry facade on the street front.

[design principle $1 \mathrm{~b}, 4 \mathrm{~b}$ ]

\section{Laminated Timber as Structure}

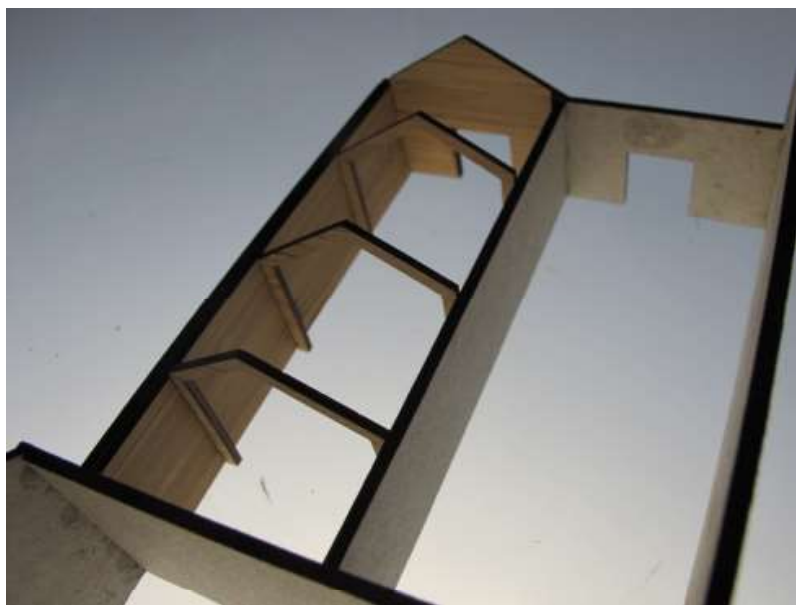

Laminated timber structural elements can serve the new build as well as strengthen the existing U.R.M. Structural elements can be expressed in the design.

[design principle $2 \mathrm{a}, 2 \mathrm{c}$ ]

\section{Change of Floor Height}

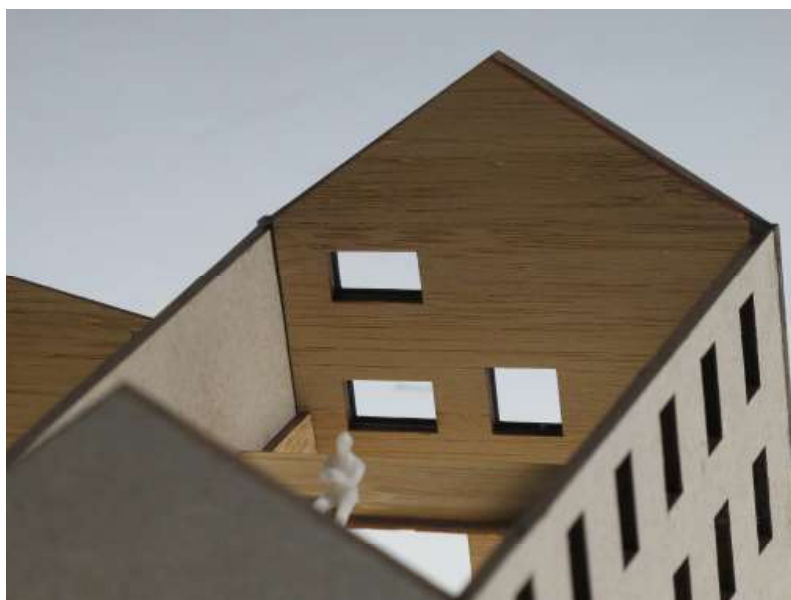

Introduction of a new floor level reduces the scale of the interior from a large industrial area to a smaller, more habitable space. It also creates a separation of zones in the honey factory.

[design principle 1c, 2b] 


\section{Introduce a New Geometry}

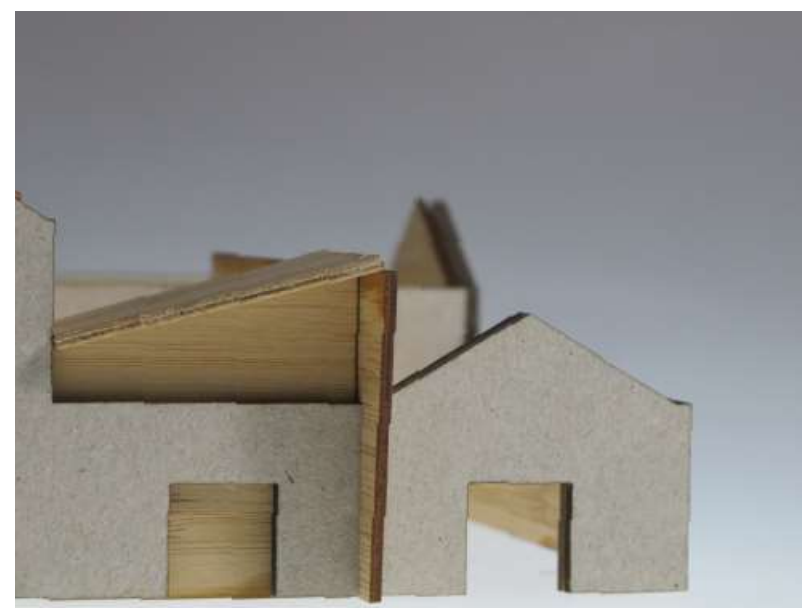

Use of laminated timber on a geometry that is different from the traditional, rectilinear layout of industrial buildings with gable roofs. By introducing this new form it distinguishes the new and old from each other.

[design principle 1a]

\section{Integrated Strategies}

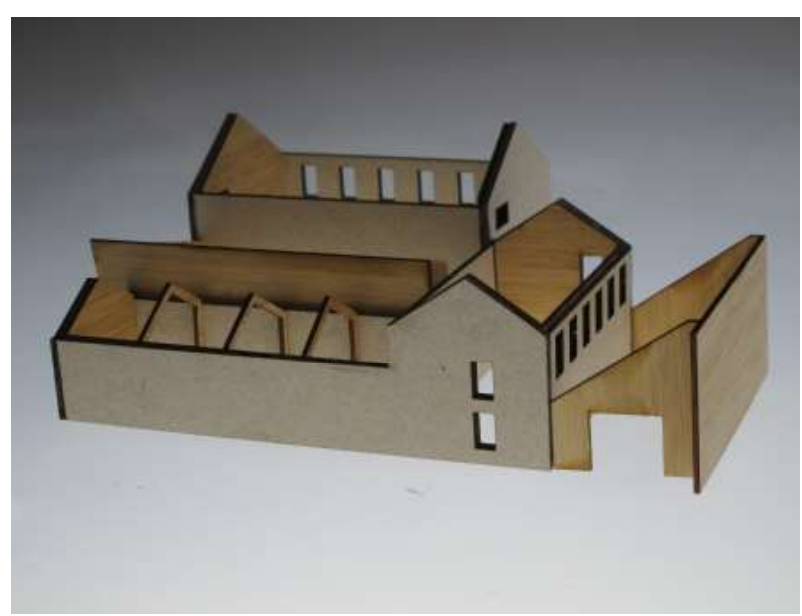

A range of design strategies using laminated timber are combined to develop an integrated response within the selected masonry building.

\section{Strategies not tested in this Iteration}

6. Corner Detail

10. Masonry Restoration

19. Portion of Site Used

\subsubsection{Iteration 5 Reflection}

This iteration tests a range of the design strategies identified on the selected site.

Expression of laminated timber is restricted to the interior as it cannot be used as exterior cladding due to weatherproofing issues, and the visibility of the existing masonry has heritage significance, relating the building to the context of the site.

A range of these design strategies will be integrated into the final design case study, which aims to provide an integrated response to the 5 design criteria: character, structure, heritage, envelope, and programme. 


\subsection{Iteration 6: Developed Design}

\subsubsection{Site Plan Development} make best use of the space in a way that reveals the heritage significance of the site. There are four key areas: honey factory, garden nursery, visitors centre, and ruins.

Introducing a new geometry for laminated timber ensures that old and new are clearly distinguishable in the design response, aiming for a cohesive relationship between plan and elevation. This geometry could be developed further so that it translates across the whole design at a range of scales.

Vehicle circulation has been developed, with most activity located at the rear of the site.
Developing specific parts of the programme to

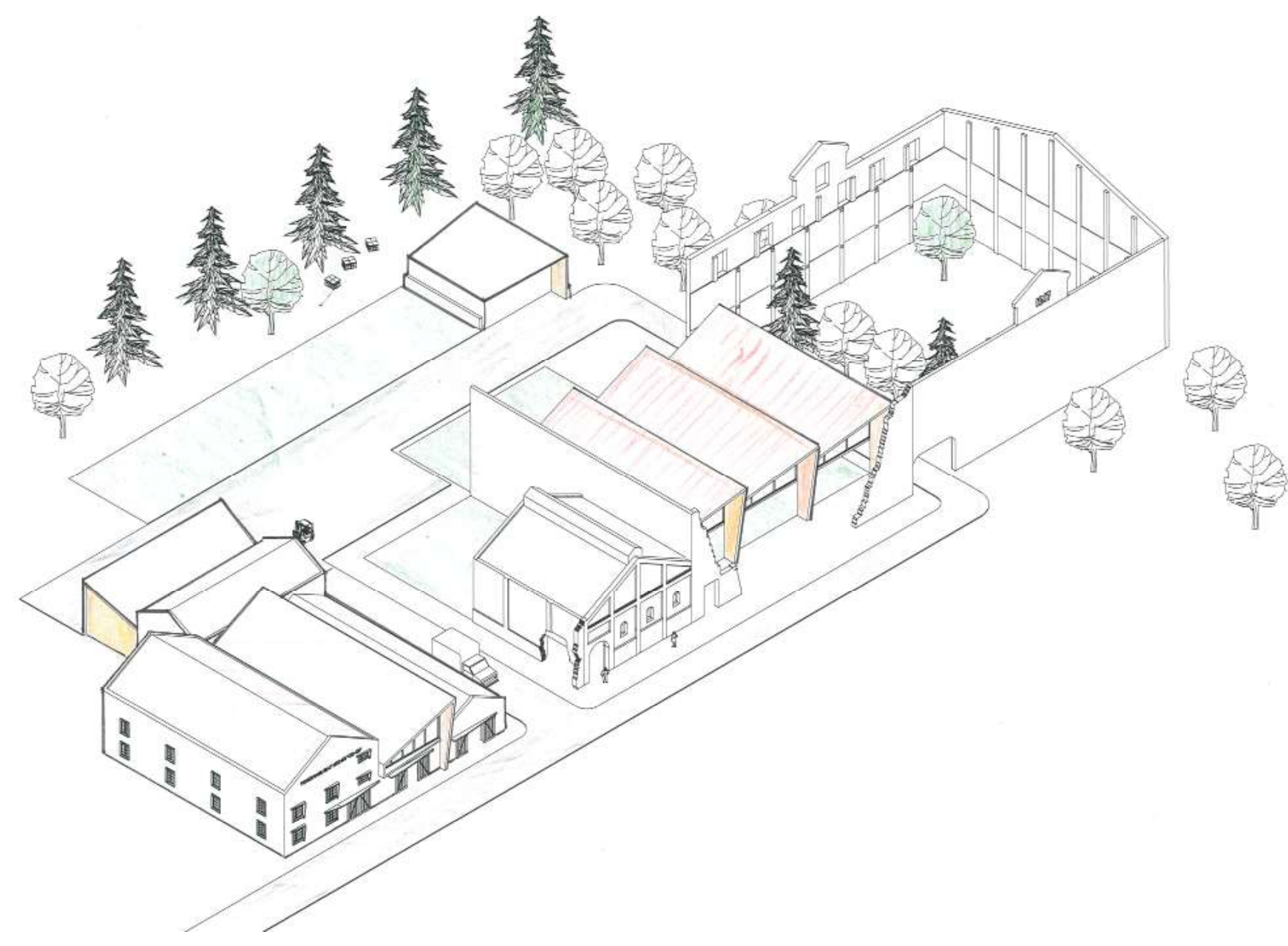

Figure 171 Site plan axonometric at August review. Source: Author's Image

Figure 172 Long section through whole site at August review. Source: Author's Image

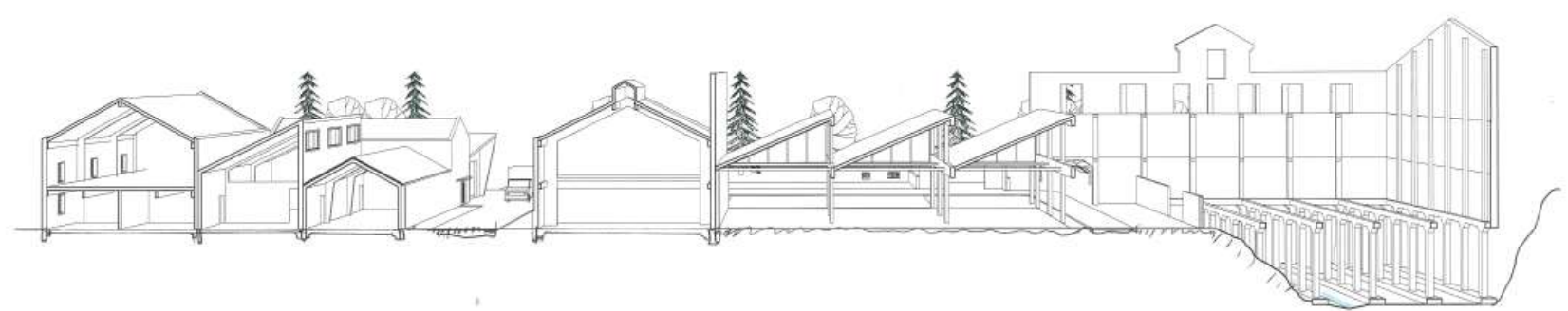


Existing masonry facade is retained along the front, with glimpses of laminated timber from the exterior that hint at the freezing works adaptive reuse.

Old and new elements are clearly differentiable by the introduced geometry. This is expressed in the roof forms, and the angular shards that protrude from the existing orthogonal footprints. The gable roofs indicate existing structures, and the mono-pitch roofs indicate a new structure. This is an effective design response as the new design remains humble, the existing buildings have prominence.

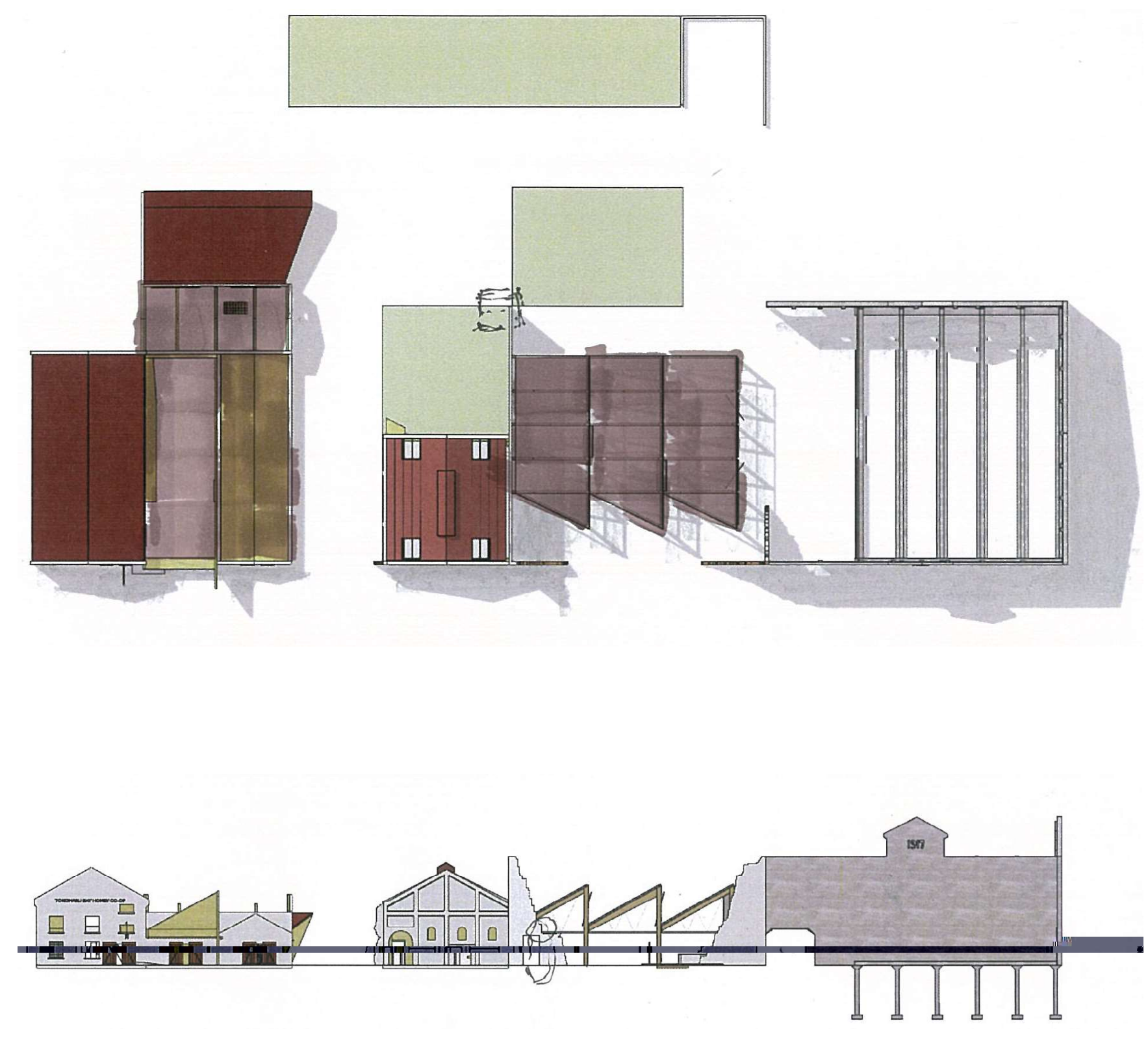




\subsection{Iteration 6: Developed Design}

\subsubsection{Envelope Development}

The street front of the freezing works is a significant part of the buildings heritage. The development explored how the treatment of the main facade could be done delicately enough to respect the heritage, but also draw attention to the buildings adaptive reuse using laminated timber.

From the approach of the main road, the first thing people will see is the laminated timber shard protruding from the main facade of the building, drawing attention to the honey factory.

Large sliding doors will open letting passersby see into the honey factory, and at night they can be shut to secure the factory.
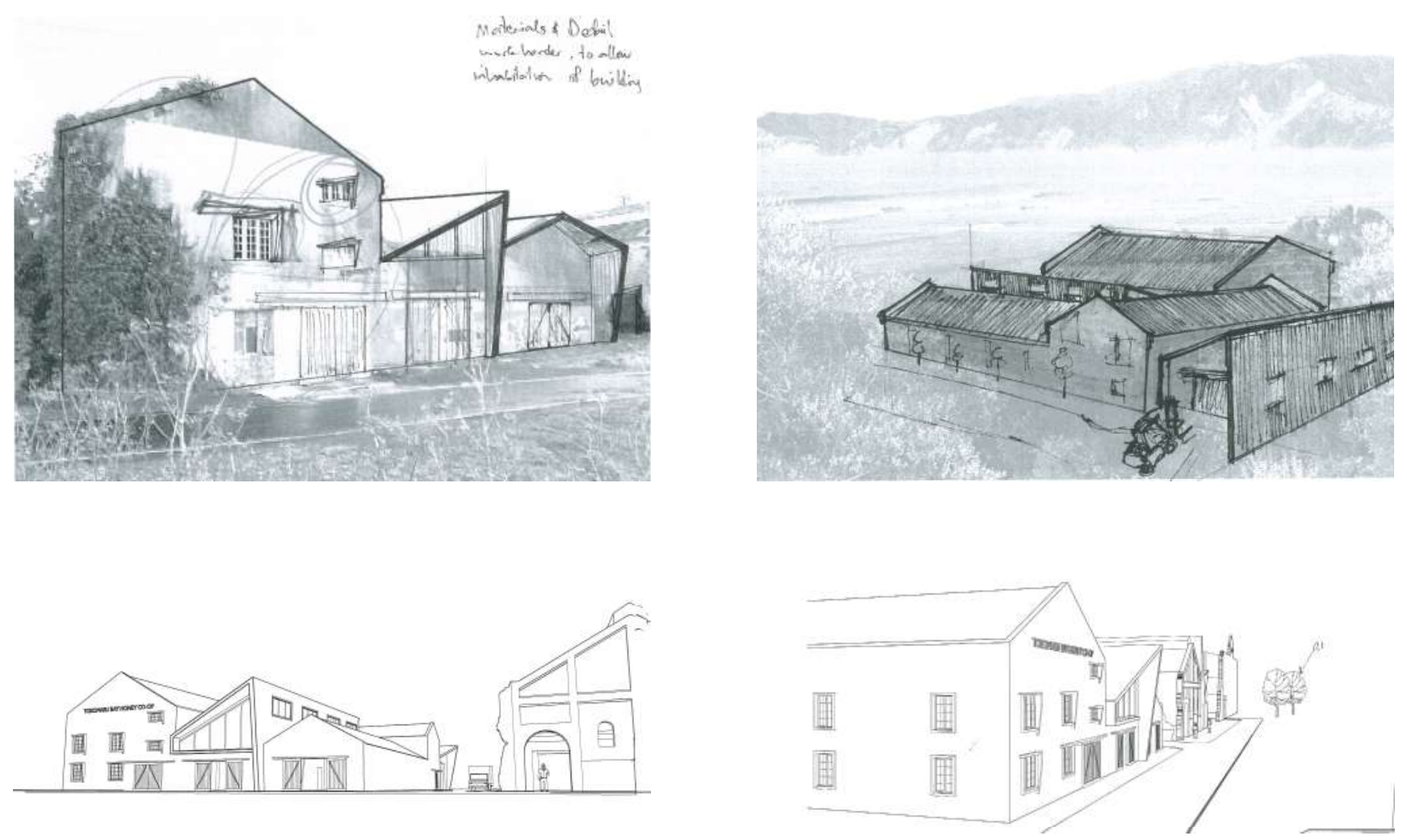

Figure 175 (top left) Front of factory with two protrusions. Source: Authors Image

Figure 176 (top right) Rear of factory with new addition. Source: Authors Image

Figure 177 (middle left) New mono-pitch roof line visible on front and rear additions.

Source: Author's Image

Figure 178 (middle right) Approaching the factory from south. Source: Author's Image

Figure 179 (bottom left) Factory with sliding doors open. Source: Author's Image

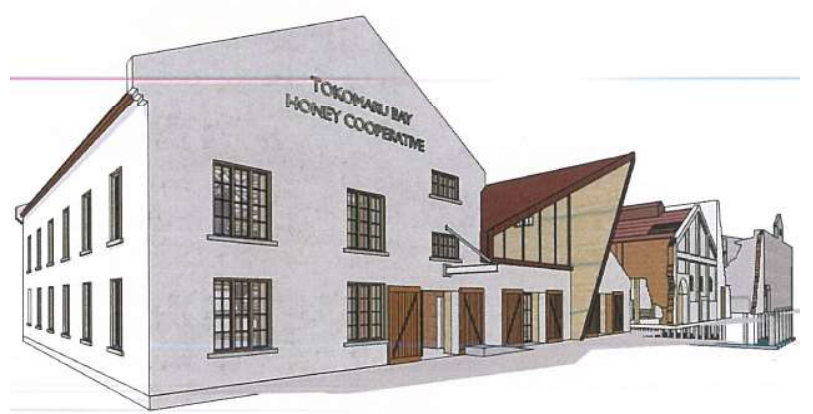




\subsubsection{Structural Development}

A combination of laminated timber will be used for structural members.

For strengthening of the existing U.R.M, laminated timber members will need to pick up horizontal loads from the masonry and transfer them to the ground. C.L.T shear walls, C.L.T floor diaphragms, C.L.T roof diagrams and glulam portal frames have been used to pick up these lateral loads. The laminated timber structure will be visible on the internal walls of the existing masonry.

The structural laminated timber members are set out on a grid that aligns with the masonry walls and original floor plan. The large spans allowed by laminated timber means that floor plans can remain uninterrupted allowing large open space for the honey programme.

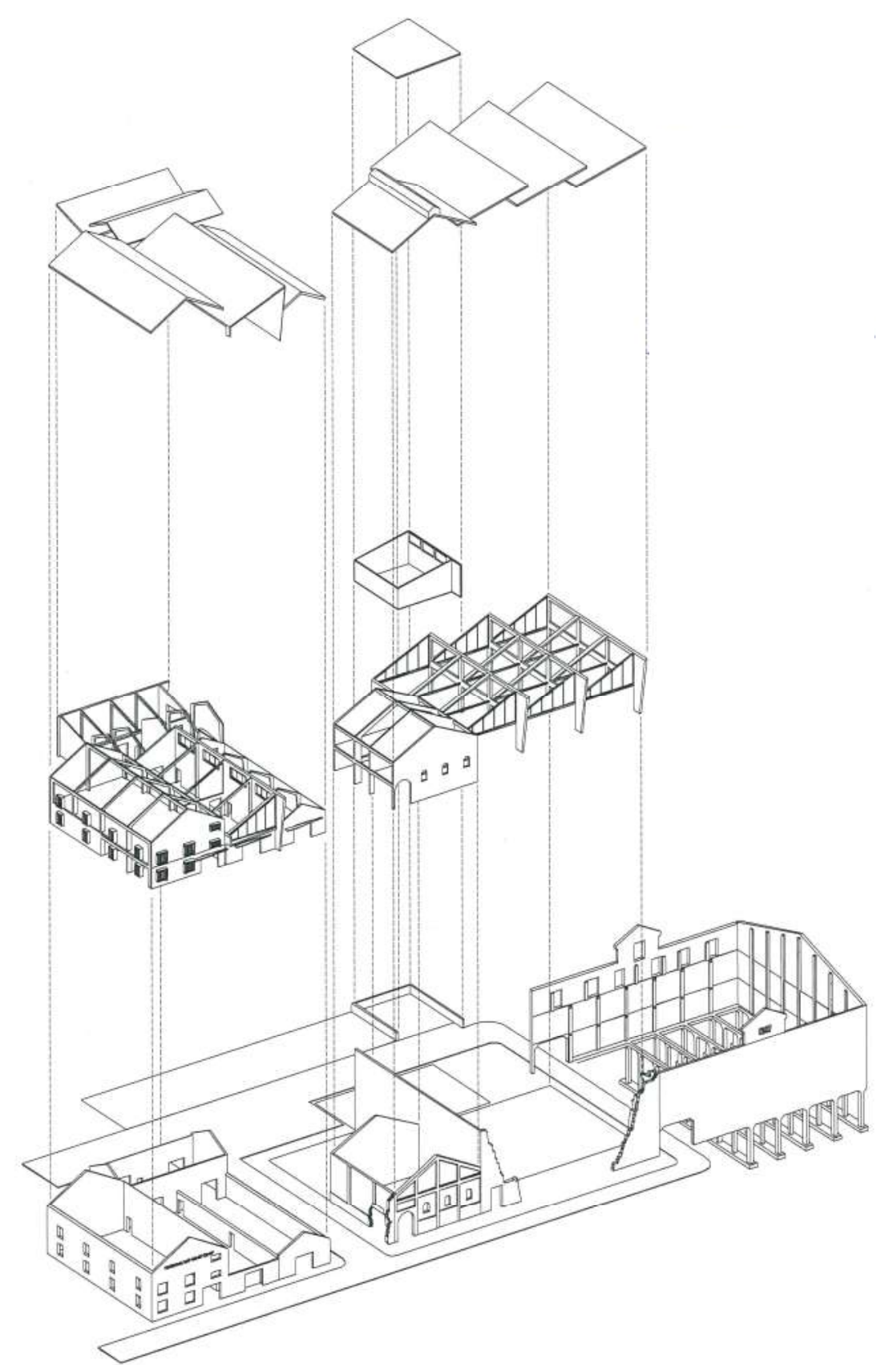




\subsection{Iteration 6: Developed Design}

\subsubsection{Honey Factory Development}

Testing of a void in the diaphragm of the honey factory floor. This keeps the building one large volume and connected, rather than having the office space completely separated from the rest of the factory. Using the same geometry on the void and staircase as used in the overall site plan makes for a cohesive design at differing scales.

The rectilinear masonry exterior is met by the angled void and staircase in the C.L.T floor diaphragm (a steel beam will be required along the edge of the void to help transfer lateral loads).

\section{Figure 181 Void tests in floor diaphragm.}

Source: Authors Image

Figure 182 Structural wall and staircase development. Source: Author's Image
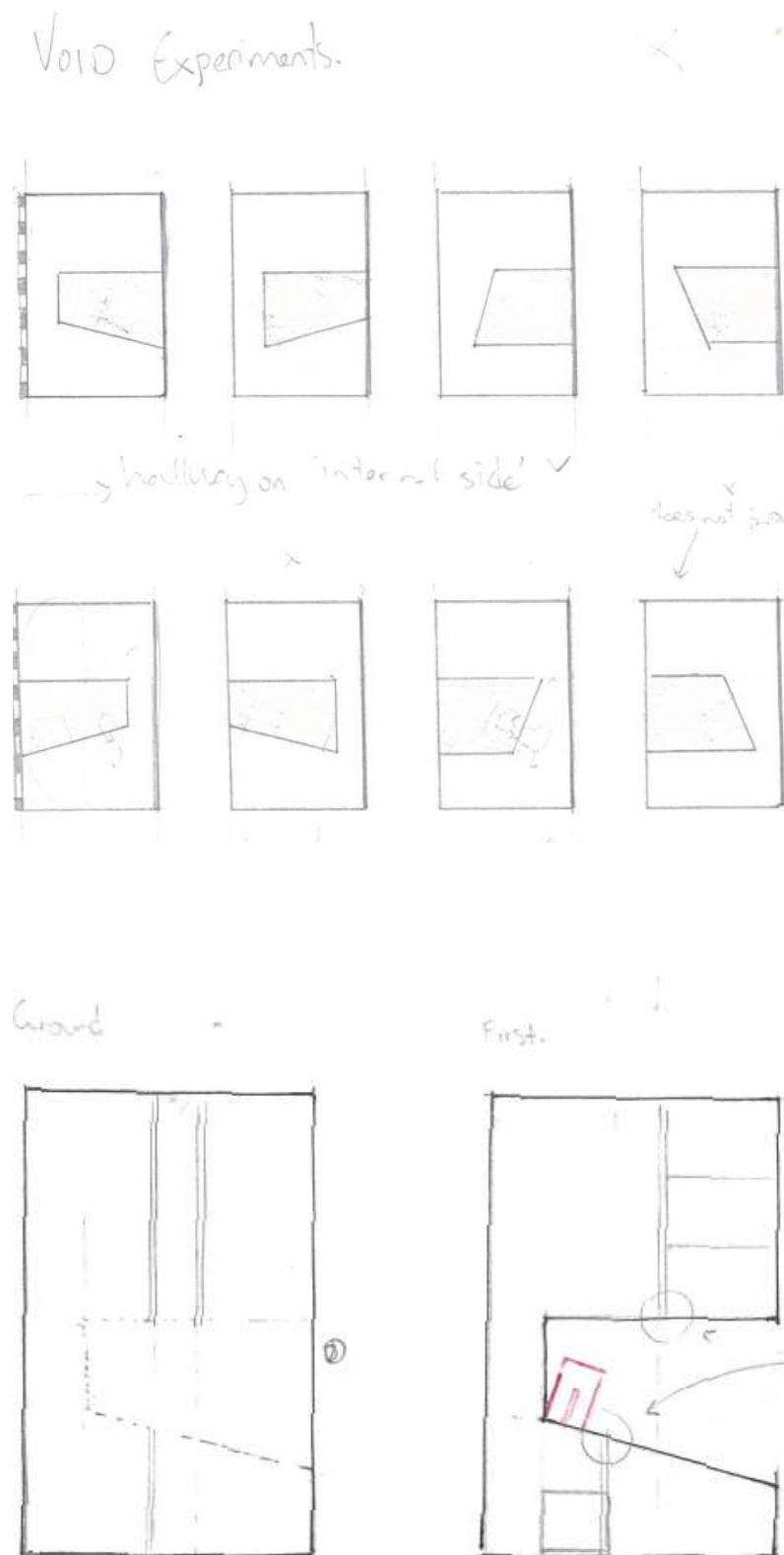

Honey factory is the most highly resolved building. Beginning with exterior masonry walls, laminated timber has been used within the building to scale down the large industrial spaces into zones appropriate for the requirements of a honey factory.

Circulation in the building is important with forklifts inside the manufacturing side of the building. There is also public and private circulation of inhabitants as public tours come through the honey factory while staff continue their work.

No permanent changes to the masonry are required, and laminated timber is inserted within the existing masonry structures. 


\subsubsection{Iteration 6 Reflection}

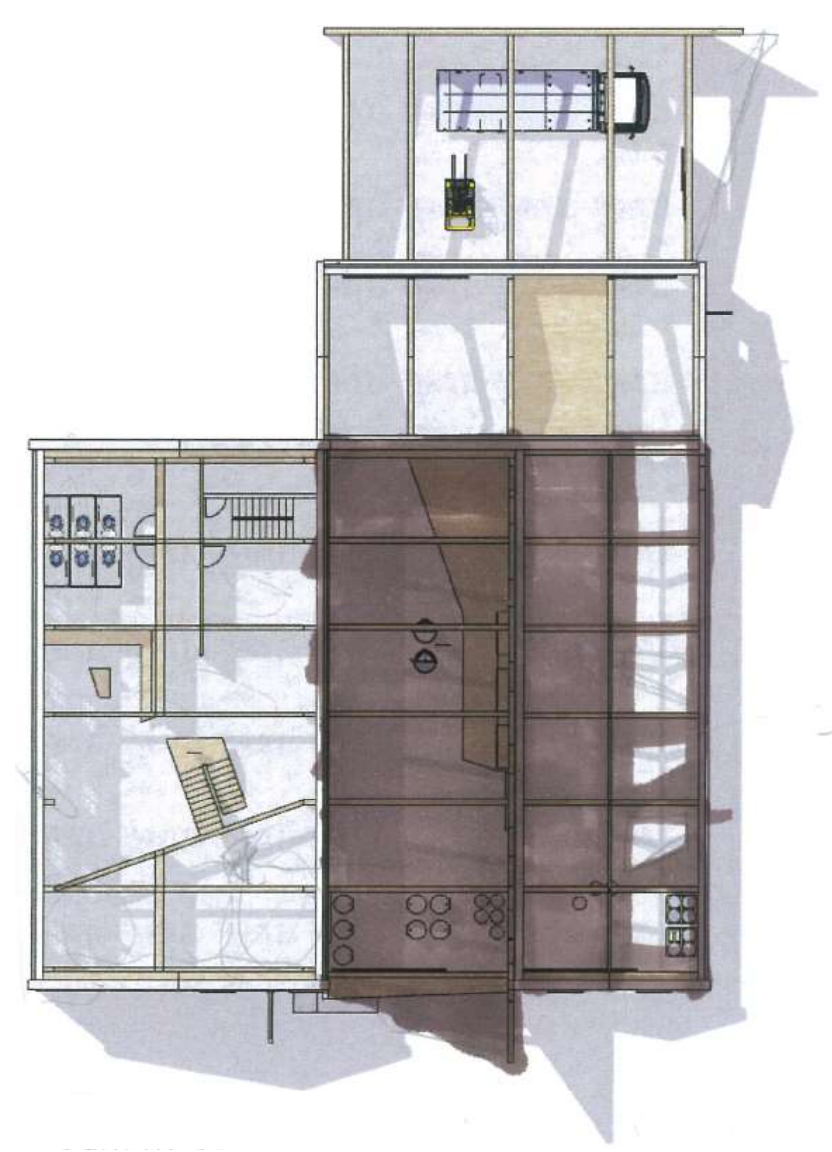

Ground Floor

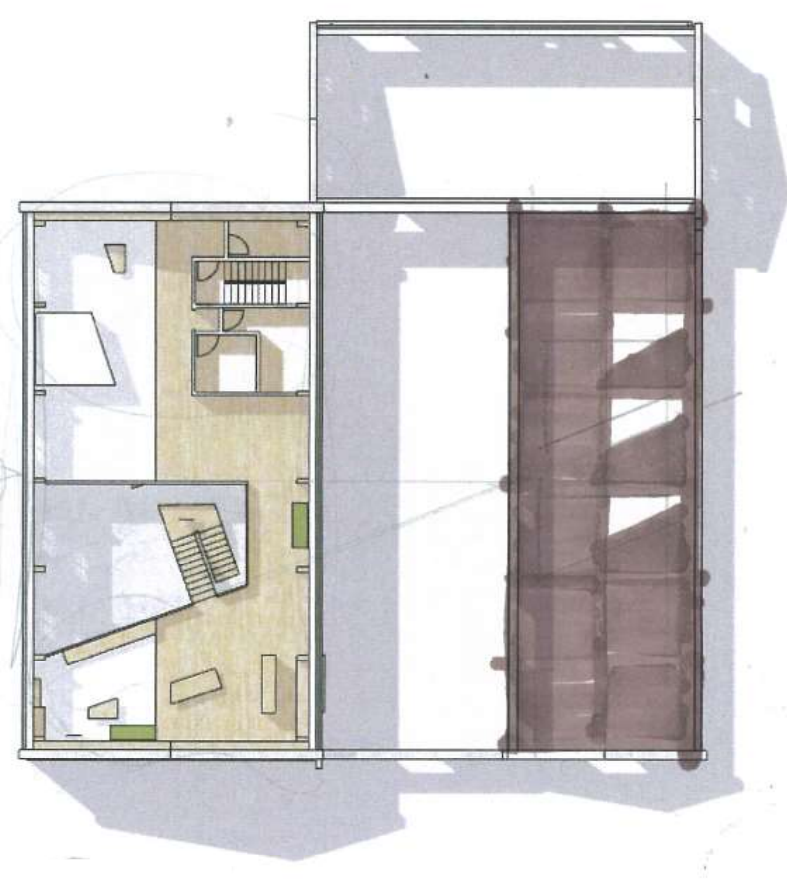

First Floor
Laminated timber has been extensively used in the adaptive reuse of the heritage building, transforming the masonry ruins into a honey factory.

\section{Response to 5 design criteria:}

\section{Character:}

The form and identity of the overall scheme has become more cohesive. The balance between old and new, laminated timber and masonry are working well.

\section{Structure:}

The strengthening of the existing U.R.M and structure of the new components are integrated together.

\section{Heritage:}

The existing masonry has remained exposed where possible to show the former life of the building. The new additions to the factory are humble design moves, which enhances the stature of the existing masonry.

\section{Envelope:}

A secure building with permeability between inside and out has been developed. A clear front and back have been developed.

\section{Programme}

Laminated timber has helped transform the existing masonry spaces to meet the requirements of the honey factory. 


\subsection{Final Design Guidelines}

\begin{tabular}{|l|l|}
\hline Criteria: & $\begin{array}{l}\text { 1. Character } \\
\text { Positive formal relationship between } \\
\text { laminated timber and U.R.M. }\end{array}$
\end{tabular}$\quad \begin{aligned} & \text { 2. Structure } \\
& \text { Laminated timber to seismically strengthen } \\
& \text { U.R.M. }\end{aligned}$

\begin{tabular}{|c|c|c|}
\hline Principles: & $\begin{array}{l}\text { a. Form } \\
\text { Establish a formal relationship that } \\
\text { achieves a unified composition while also } \\
\text { distinguishing between laminated timber } \\
\text { and U.R.M. } \\
b \text { Identity } \\
\text { Laminated timber should be identifiable } \\
\text { from the exterior to identify the buildings } \\
\text { new use } \text { Scale }_{\text {c. }} \\
\text { Ensure design strategies address three } \\
\text { distinct scales: } \\
\text { 1. Large. Re-scale of large industrial } \\
\text { site for inhabitation and artisan food } \\
\text { production. } \\
\text { 2. Medium. Retain simplicity and } \\
\text { industrial grandeur of existing } \\
\text { buildings. } \\
\text { 3. Small. Retain trace of industrial } \\
\text { heritage in new design at a detail level } \\
\text { (e.g. wall junctions and openings). }\end{array}$ & $\begin{array}{l}\text { S. Strengthening } \\
\text { Laminated timber to provide adequate } \\
\text { structural support to existing U.R.M. } \\
\text { b. Structural Integration } \\
\text { Structural laminated timber elements } \\
\text { are integrated with structural masonry } \\
\text { elements. } \\
c \text { Expression } \\
\text { Express structural laminated timber } \\
\text { elements visually in the design response. }\end{array}$ \\
\hline
\end{tabular}




\section{Heritage}

Retain and enhance significance of heritage site.

\section{Envelope}

Re-establish building envelope.

\section{Programme}

Laminated timber facilitates introduction of new production activity.

\section{a. Understand + Acknowledge}

Understand the significance of the U.R.M industrial heritage site before designing. Determine a level of change that acknowledges the significance of the site.

\section{b. Reversibility}

Allow for the changes within the site to be reversed (this allows the opportunity for future interpretations of the heritage.

\section{c. Context}

Conserve relationship between the U.R.M industrial heritage building and its setting. This preserves significant views to and from the U.R.M industrial heritage site.

\section{d. Reveal significance}

Reveal and interpret the heritage of the site through adaptive reuse.

\section{e. Add Significance}

Introduce a program that builds on the existing heritage of the site and contributes to the heritage of the site in the future.

\section{a. Reinstate envelope Reinstatement of building envelope (currently in ruins).}

\section{b. Front/back}

Preserve masonry frontage, separate front of house and back of house.

\section{c. Public/private}

Consideration of the different needs of public and private user groups when accessing the building.

\section{d. Permeability}

Provide openings along exterior envelope that visually promote laminated timber and indicate the new program within existing U.R.M building.

\section{e. Weather-tightness}

Address weather tightness between new and old.

\section{f. Security}

Provide secure facilities within heritage site.

\section{a. Programme Selection}

Select a program that allows the U.R.M industrial heritage site to be adaptively reused.

\section{b. Function}

Use laminated timber to meet individual spatial requirements of new program within U.R.M site.

\section{c. Versatility}

Allow for future expansion and development of the site. Buildings should be adaptable enough allowing future change in use. 


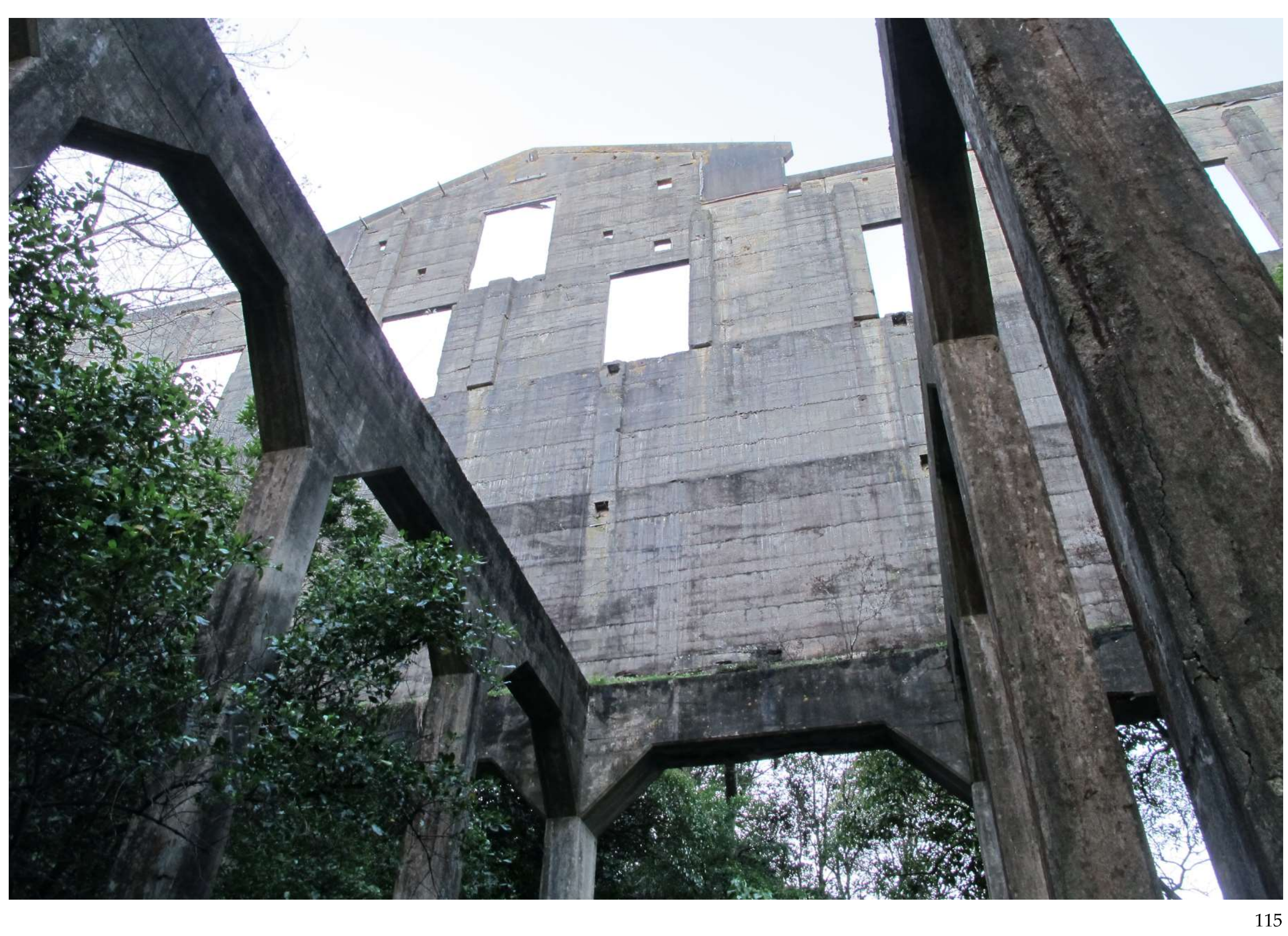




\subsection{Introduction}

This chapter presents the final design case study for the adaptive reuse of the former Tokomaru Bay Freezing Works on the East Coast.

The Tokomaru Bay freezing works ruins is a typical example New Zealand's forgotten industrial heritage. The case study is used to address the research question of how laminated timber can be used in the adaptive reuse of U.R.M industrial heritage buildings. The case study has been broadly developed at large scale before focusing on the honey factory, which is more highly resolved. The case study aims to show the compatibility of laminated timber and U.R.M.

The case study responds to the design principles that were developed through chapters 2-5; and aims to meet the five design criteria: character, structure, heritage, envelope and programme.

\subsection{Master Plan}

The master plan shows how the proposed Tokomaru Bay Honey Co-operative sits within the wider Waima Heritage precinct. The final design is located entirely within the existing ruins to preserve the relationship between the existing heritage building and its context.

The master plan addresses the scale of the site, which shows how the overall Waima heritage precinct could be developed in the future.

\section{Master Plan Key:}

1. Honey factory + Mānuka nursery

2. Mānuka Nursery Expansion

3. Visitor Centre Expansion

4. By-products Expansion (potential for new business opportunity)

5. Public car park

6. Wharf 


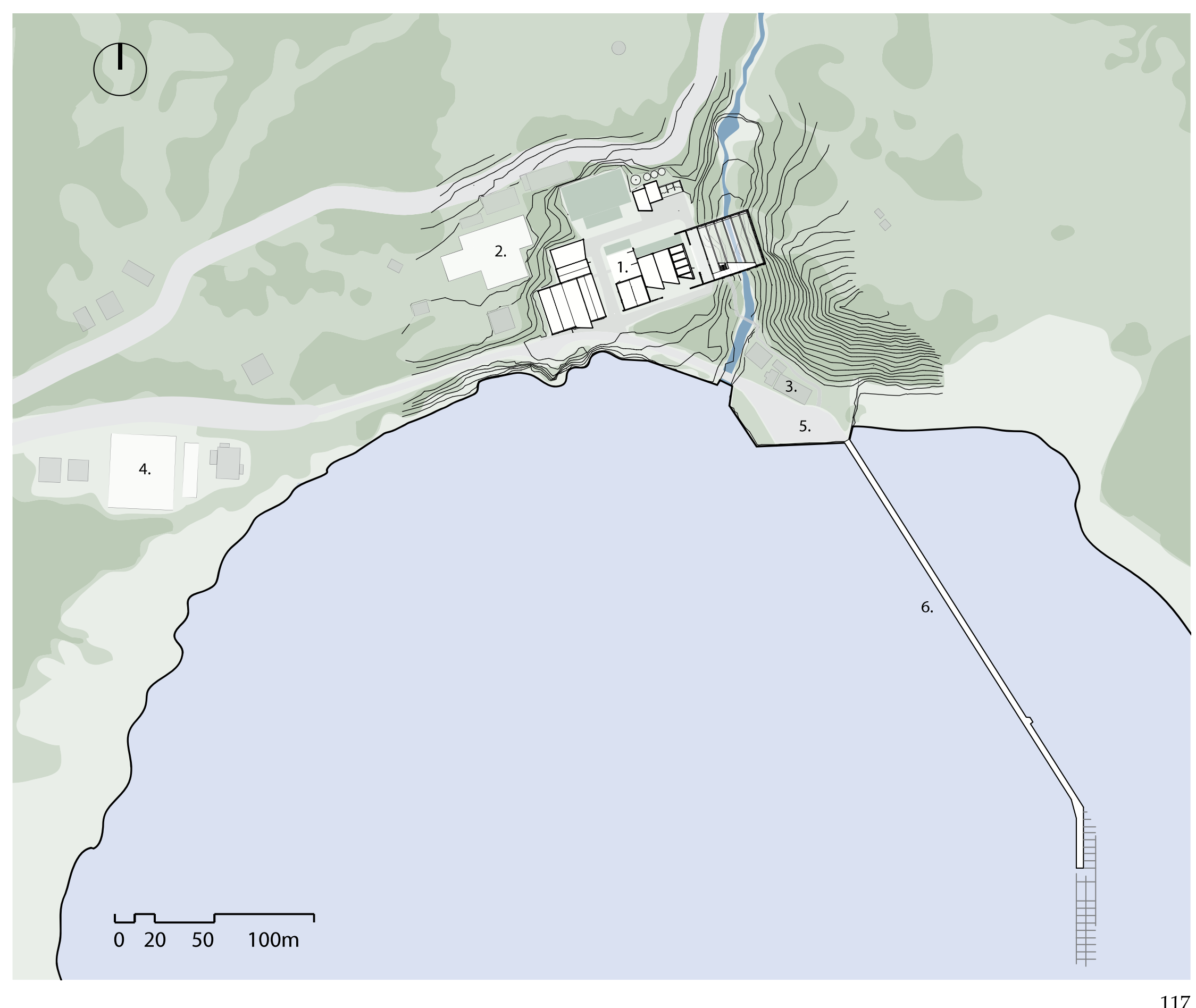




\subsection{Urban Design}

\section{Site Topography}

There are several existing site conditions that informed layout of the site plan.

The sea and stream provide two natural boundaries for the freezing works (1917 addition was built over the stream).

The site contours show how the cut and fill of soil was used to create a building platform for the freezing works. The original site plan is set out on an orthogonal axis.

The current state of the ruins provides opportunity to reconnect the site with its context. There are 3 view shafts that allow permeability through the site.

Four distinct zones make up the final design for the honey co-operative. The honey factory and visitors centre are in the most intact buildings. The Mānuka nursery is located on former building platforms of demolished buildings. The fourth zone is the remains of the freezing works over the stream, which will be left to decay over time.

There are a range of ways people will occupy and circulate around the site. There are both vehicle and pedestrian requirements for both public and private occupants.

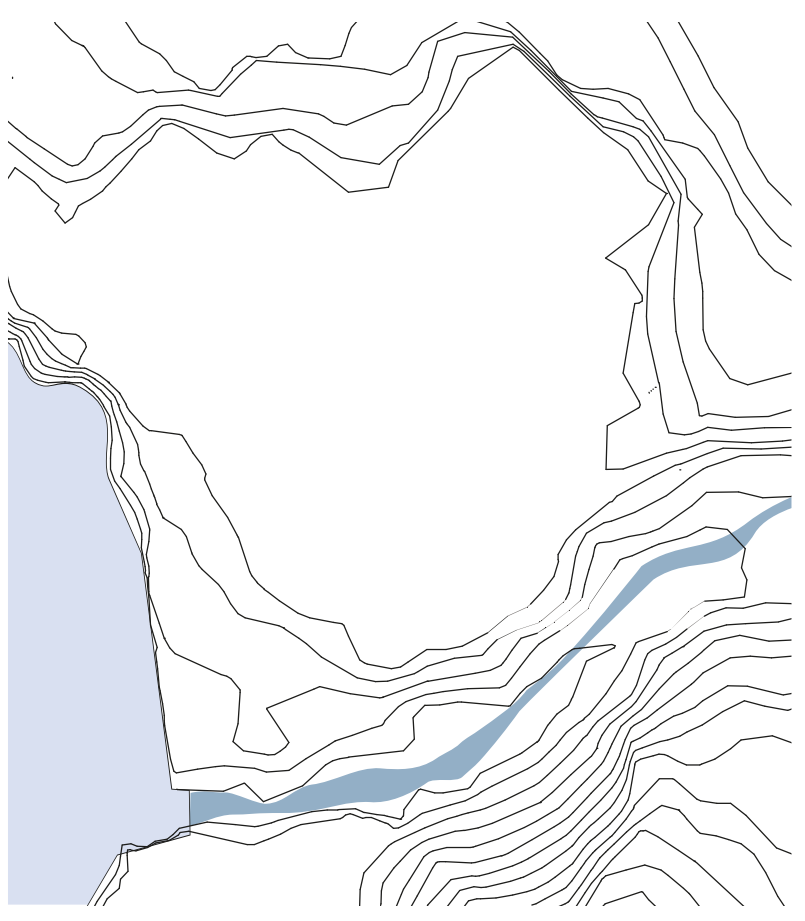

$\square$ EXISTING CONTOURS (2m) STREAM

\section{Original Site Plan}

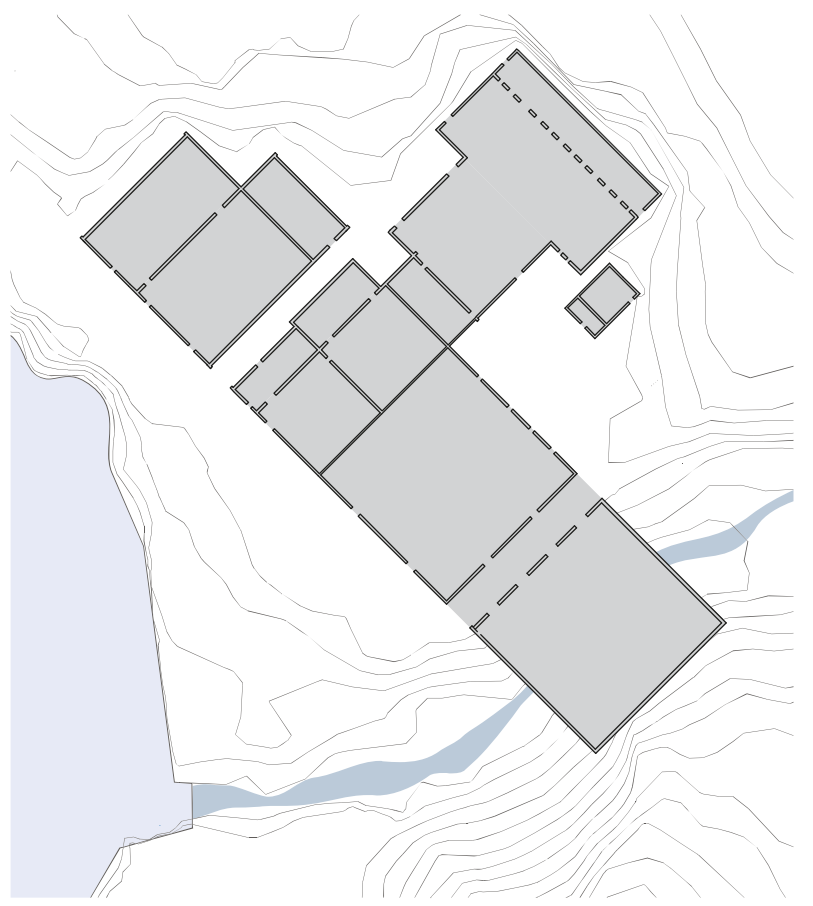

ORIGINAL FLOOR PLAN (I9I7) 


\section{Existing Ruins (2017)}

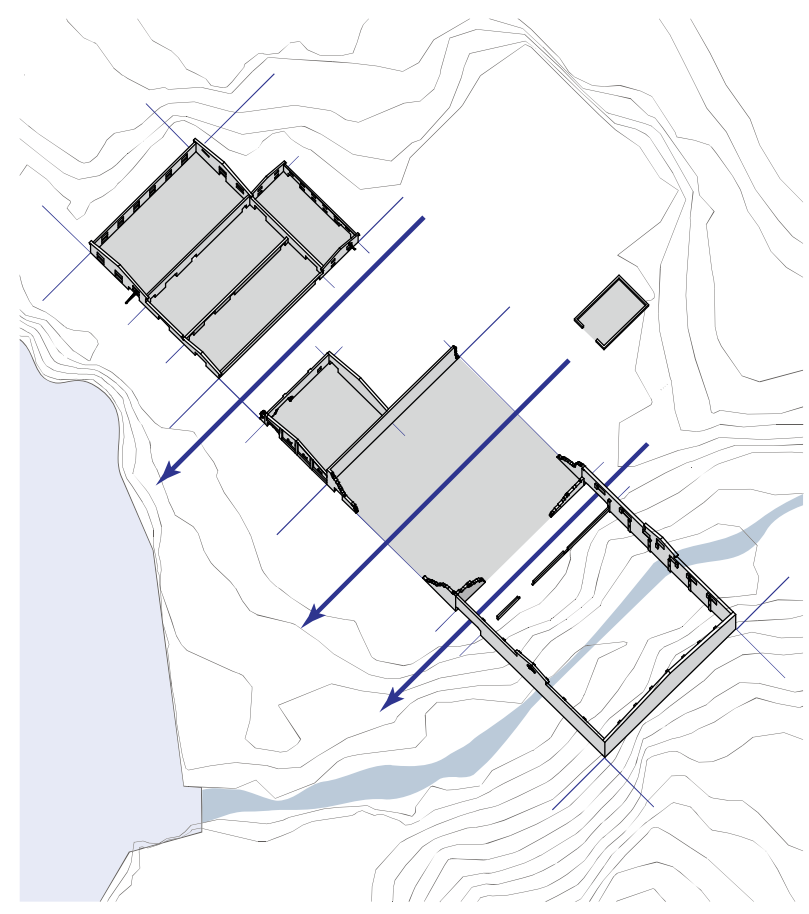

$\square$ ORTHOGONAL GRID

- VIEW SHAFTS

\section{Zones}

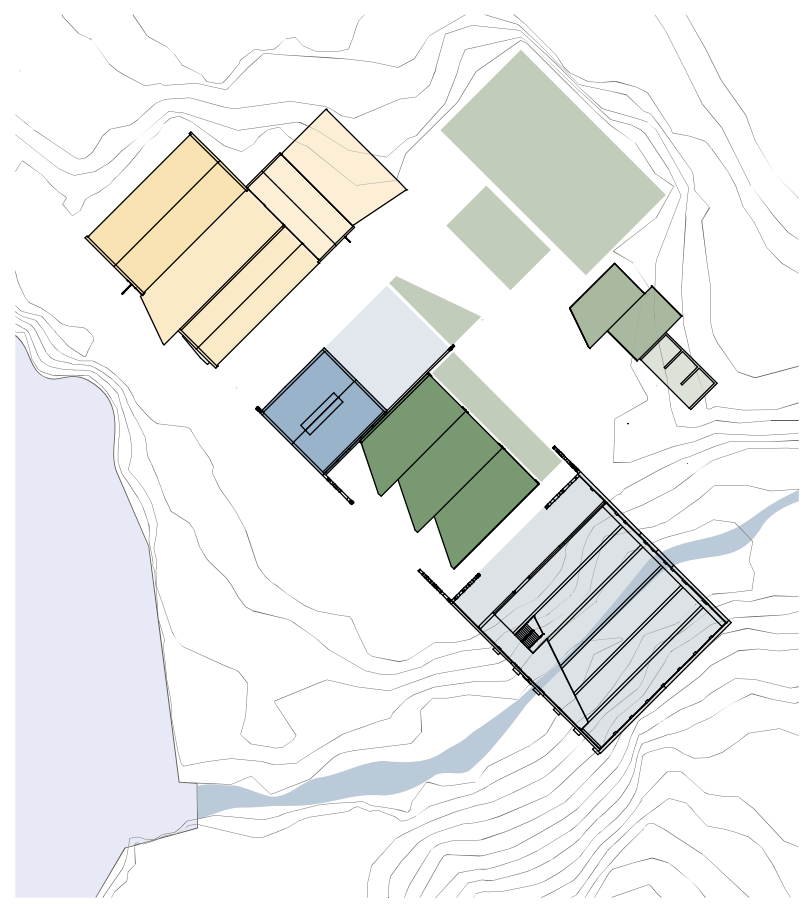

$\square$ HONEY FACTORY

MANUKA NURSERY

- VISITOR AREA

RUINS

\section{Circulation}

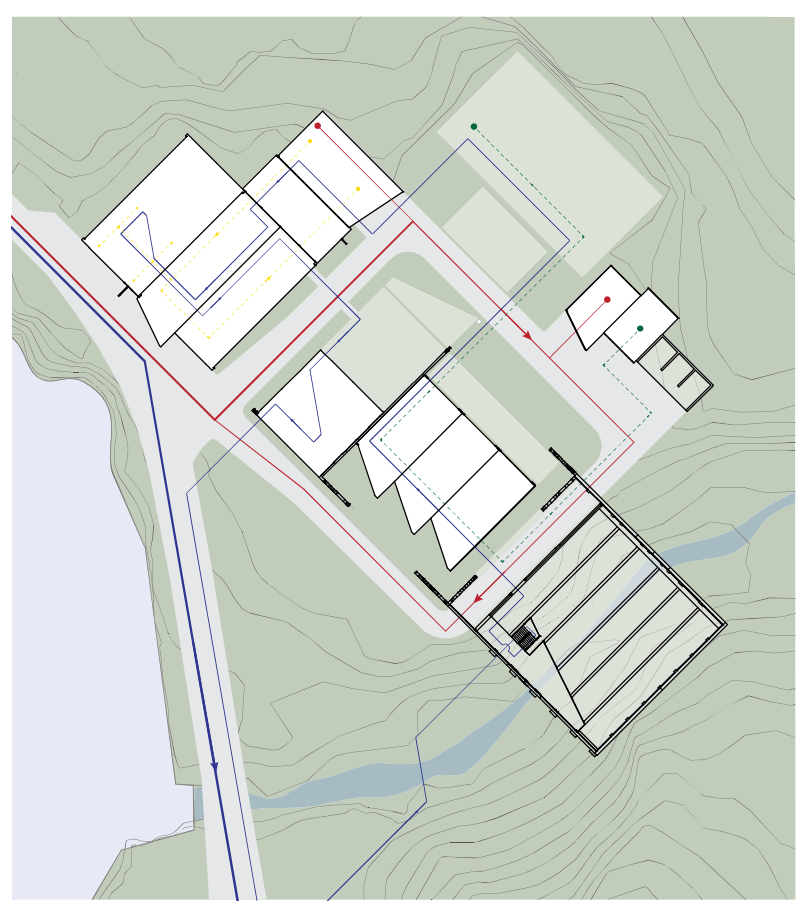

\section{$\square$ PRIVATE VEHICLES}

HONEY PRODUCTION

MANUKA PRODUCTION

口 PUBLIC VEHICLES 


\subsection{Site Plan}

The site plan shows the proposed development for the Tokomaru Bay Honey Co-operative. The varying condition of existing buildings contributed to their new function in the final design. Four distinct zones make up the final design for the honey co-operative:

\section{Honey Factory}

Located in the former manure and tallow works building.

\section{Visitors Centre}

The visitors centre, located in the former engine room, could consist of the following: museum, gallery, shop, and cafe. As a large, versatile open space it has potential to be used for local meetings and community events.

\section{Nursery}

The Mānuka nursery is based on the concrete footprints of buildings that have been demolished. The covered propagation area is located within the former freezing chambers, and the outdoor area is located on the footprint of the former fellmongery.

\section{Ruins}

The reinforced concrete structure over the stream has been left in ruins with a viewing platform inserted inside. Native trees will continue to grow up through the existing columns.

\section{Site Plan Key:}

1. Honey Factory

a. Loading Bay

b. Storage

c. Extraction Room

d. Packing Room

e. By-products, Offices, Back of House

2. Visitors Centre

a. Shop, Cafe, Museum, Gallery

b. Outdoor Area

\section{Nursery}

a. Propagation

b. Stand Out Area

c. Sheds

d. Bulk Storage

\section{4.. Ruins}

\section{Car parks}

a. Staff Car Park

b. Public Car Park 


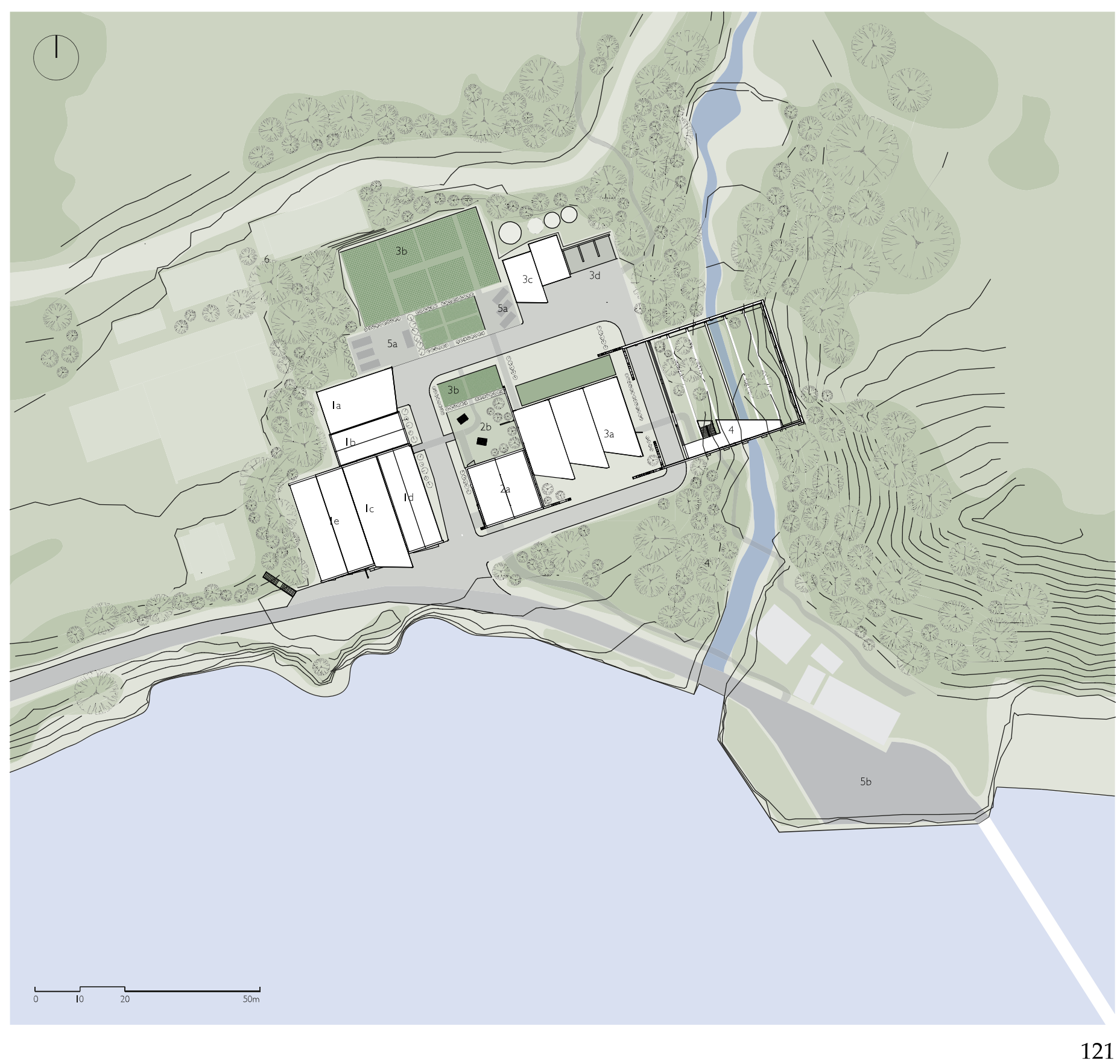


6.4 Axonometric Site Plan

Gold tone indicates laminated timber components introduced in the adaptive reuse of the former freezing works. 


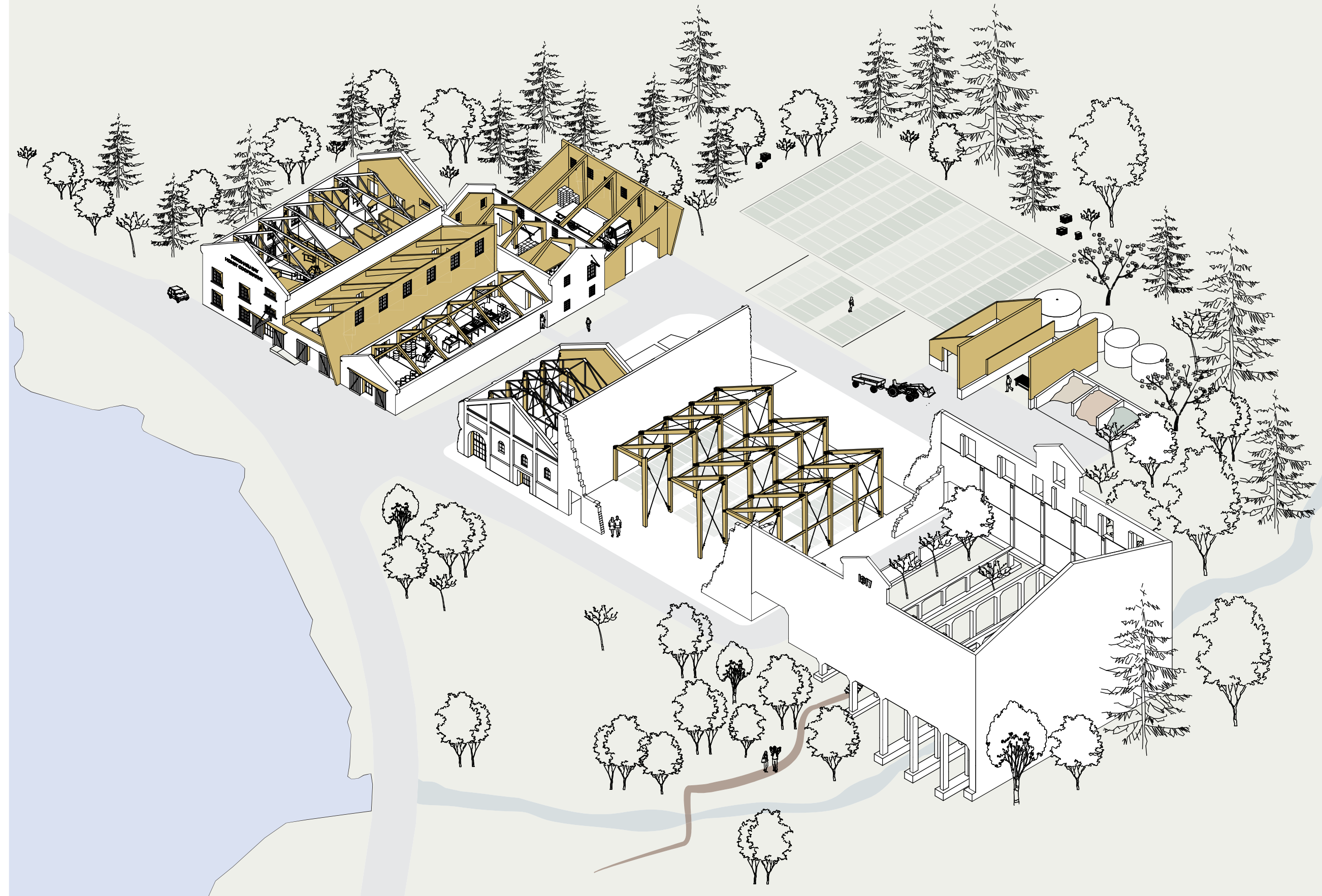




\subsection{Honey Factory Floor Plans}

The honey factory is located within the former manure and tallow works and is the most highly resolved building in the design case study. One side of the building handles the storage, extraction and processing of the honey and the other looks after honey by-products, back of house requirements and office space on the upper floor.

The factory uses both C.L.T and glulam timbers in the adaptive reuse of the masonry building.

The entire factory is housed within the masonry footprint of the existing building except for the loading bay, which is a new building. This allows for a large opening that enables trucks and forklifts to enter the building and removes the need for irreversible damage by creating a large opening in the existing buildings.

\section{Mānuka Honey Factory Key:}

1. Loading Bay

2. Hot Room

3. Honey - Extraction

4. Honey - Filtration/Blending

5. Honey - Bulk Storage

6. Bottling and Packaging

7. Storage

8. Honey By-products

9. Research and Development

10. W/C

11. Staff Lockers

12. Open Plan Offices

13. Kitchen

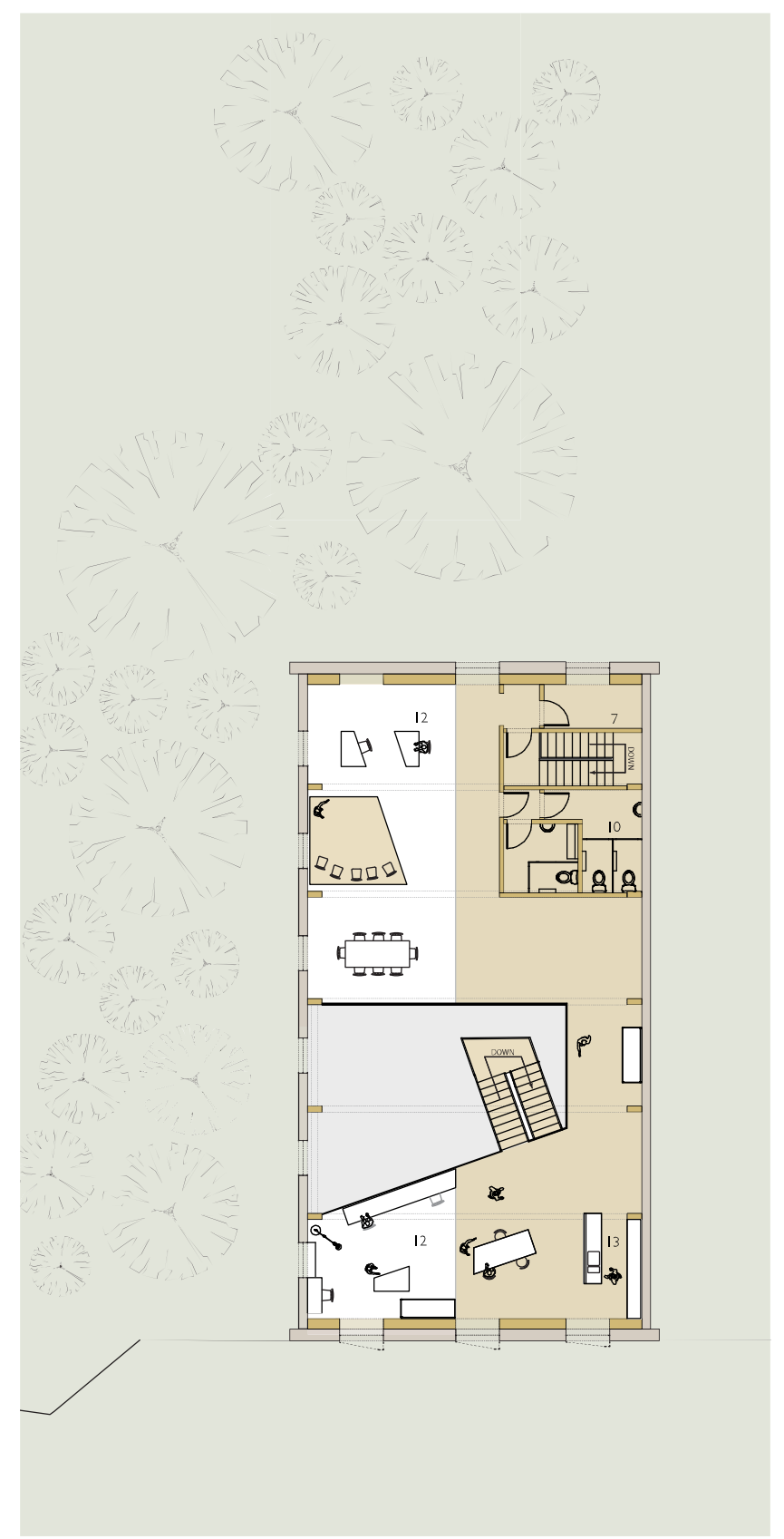




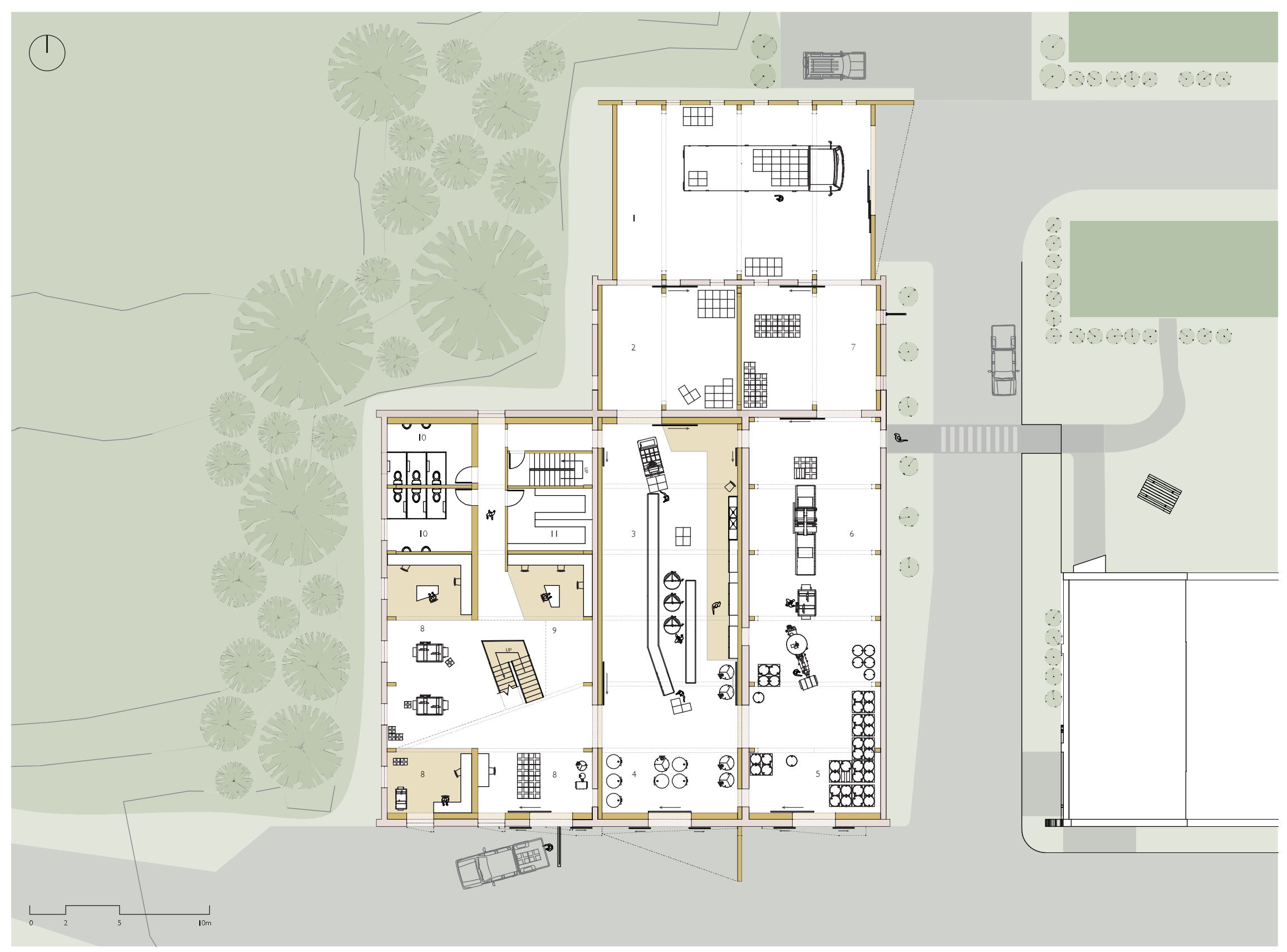




\subsection{Long Section}

(refer figures 202, 203, 204 for larger details)

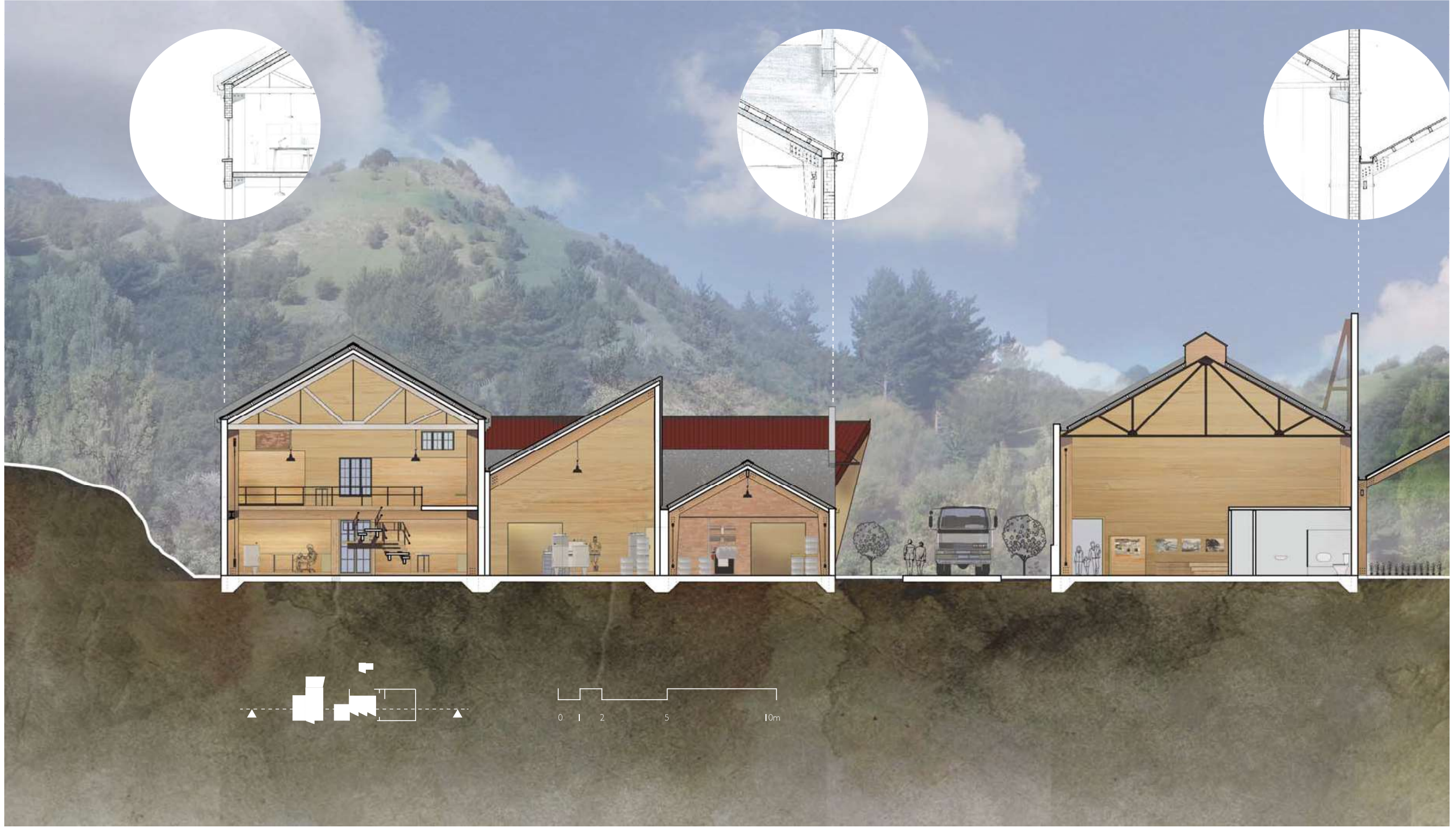

Figure 195 Long section through honey factory, visitors centre, nursery and ruins. 


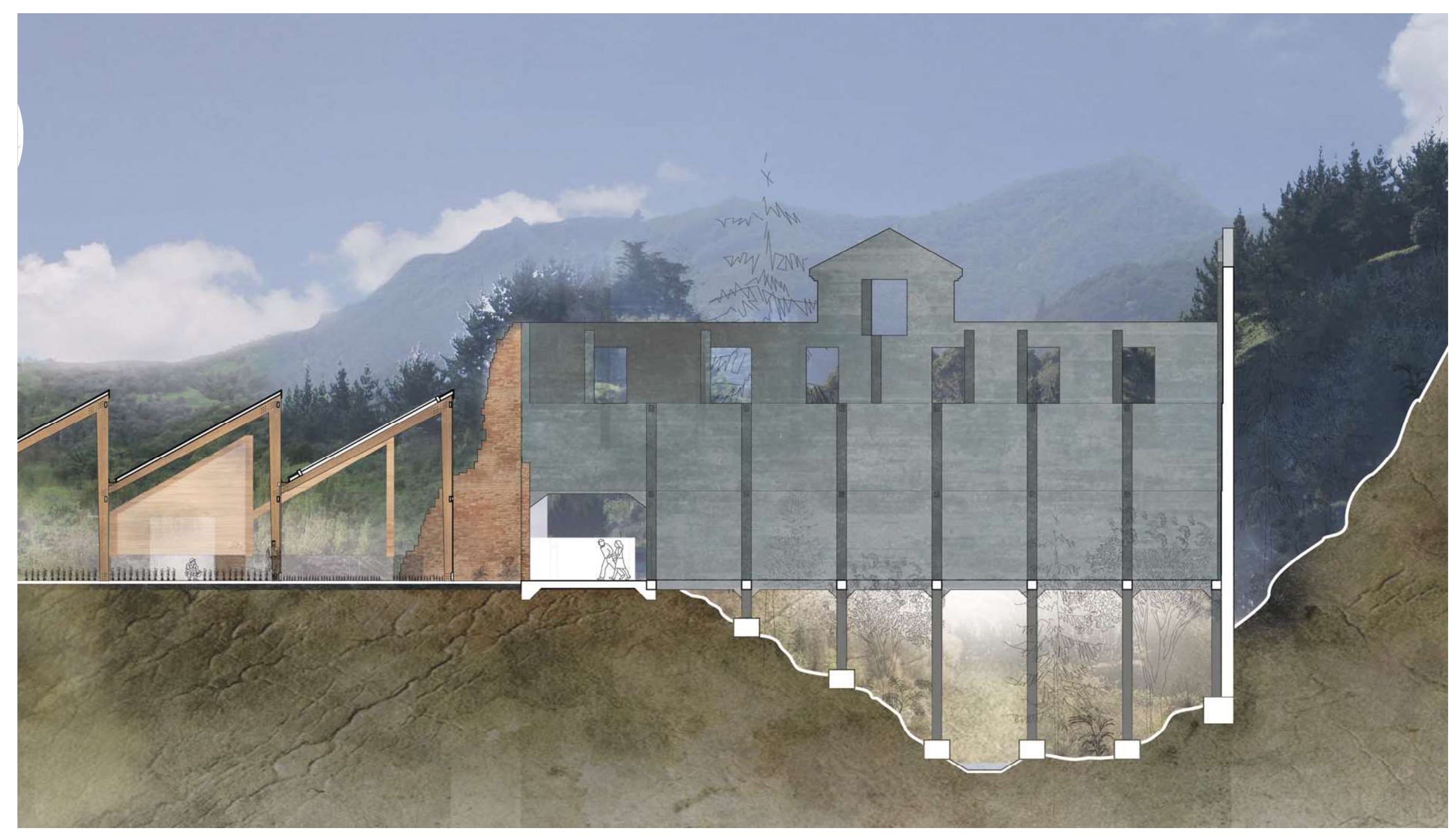




\subsection{Exterior Envelope}
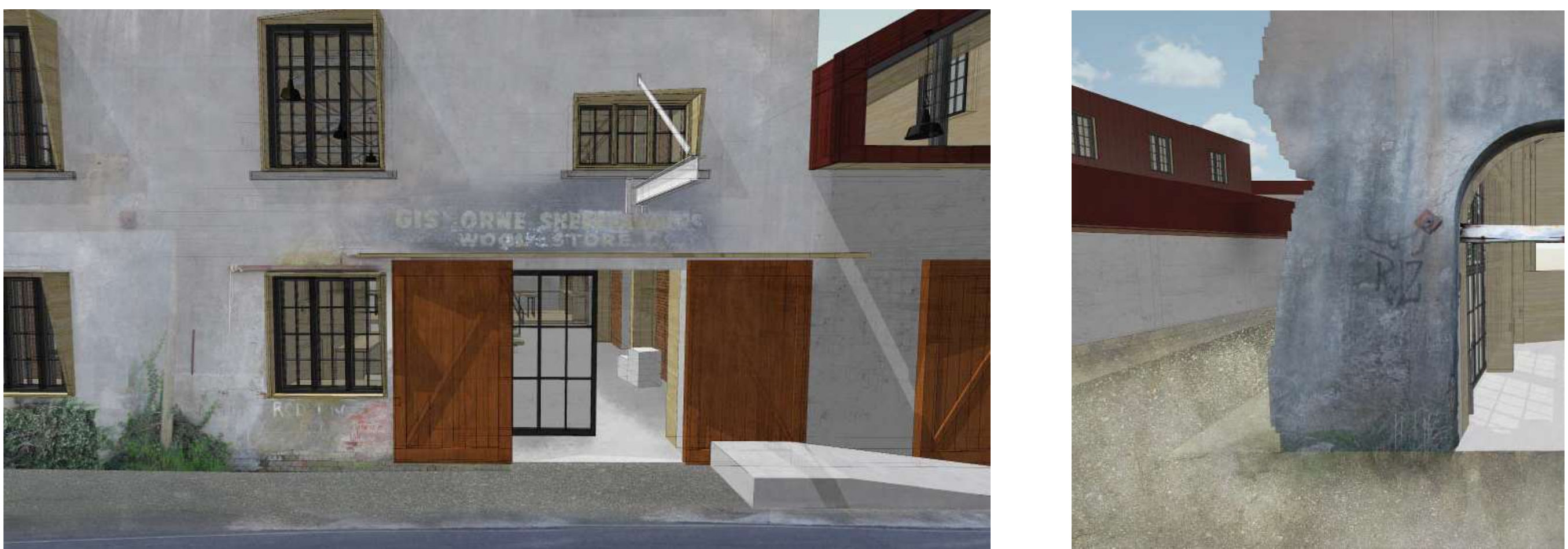

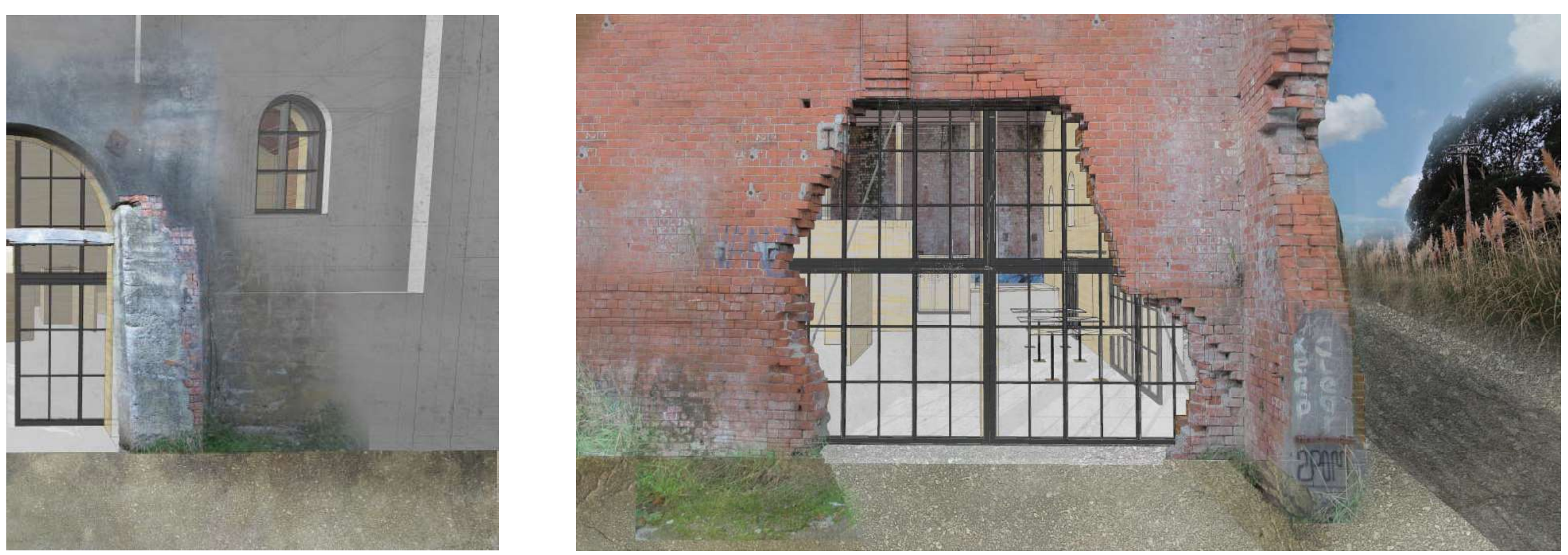

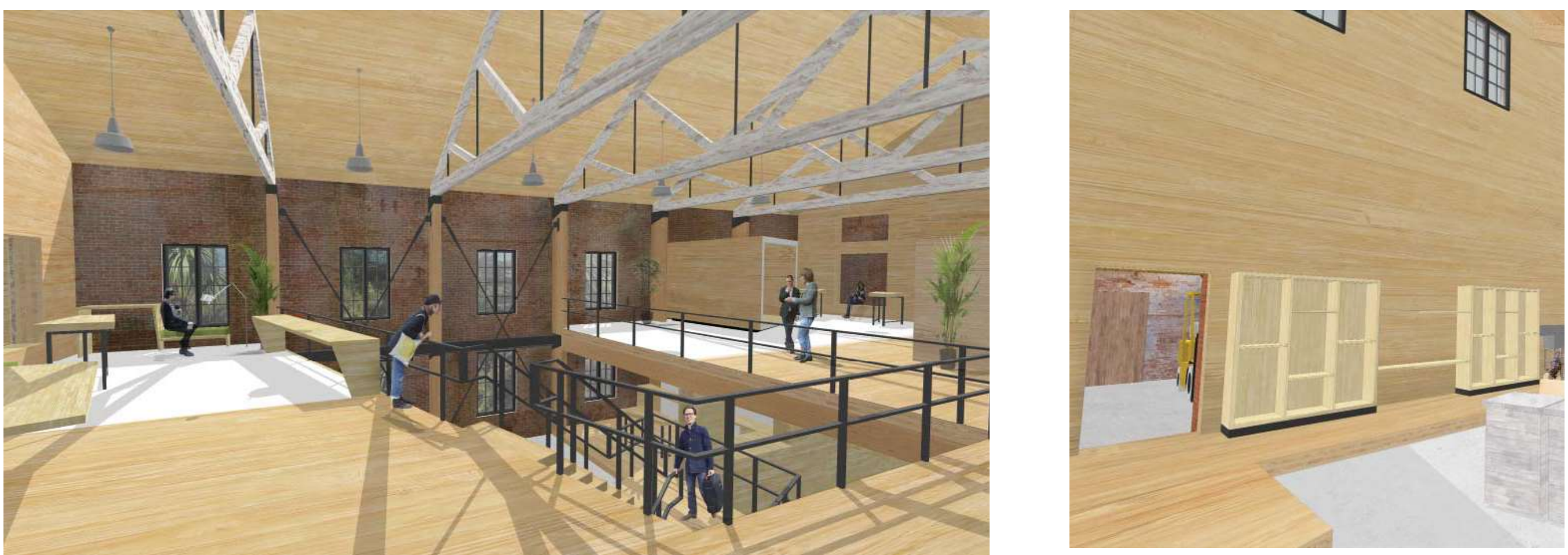

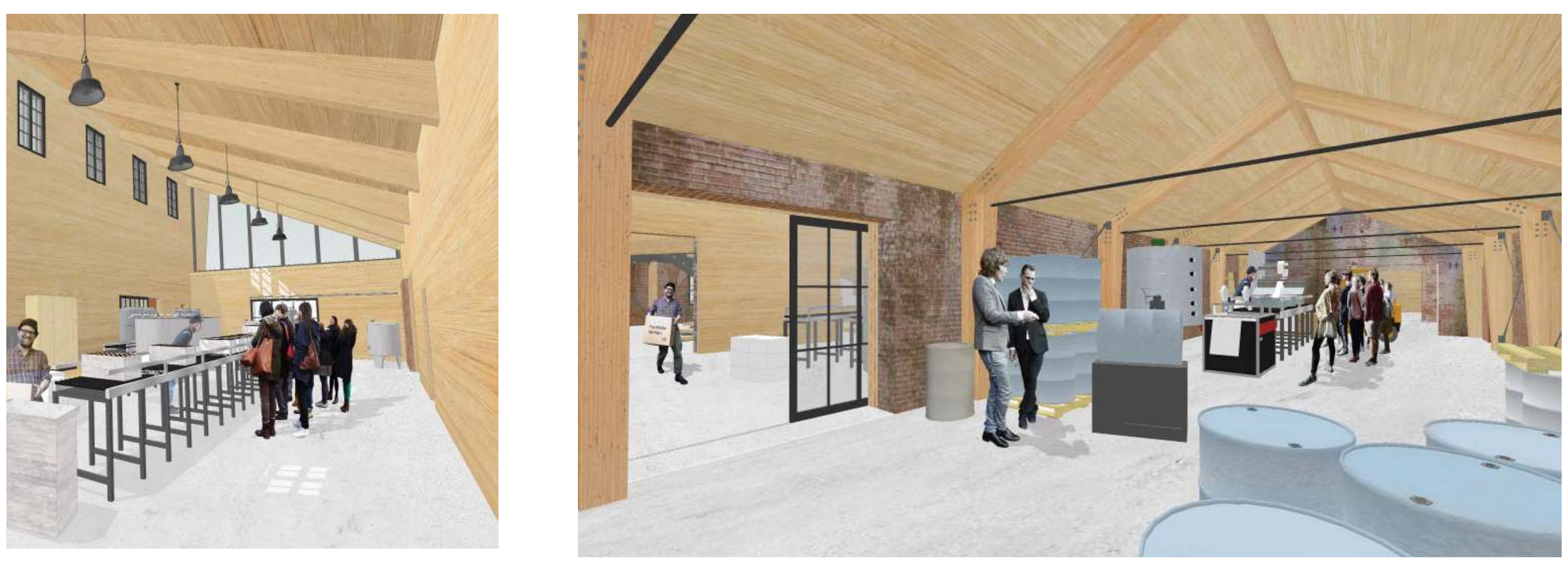


\subsection{Details}

(refer detail location on long section [Fig. 194])
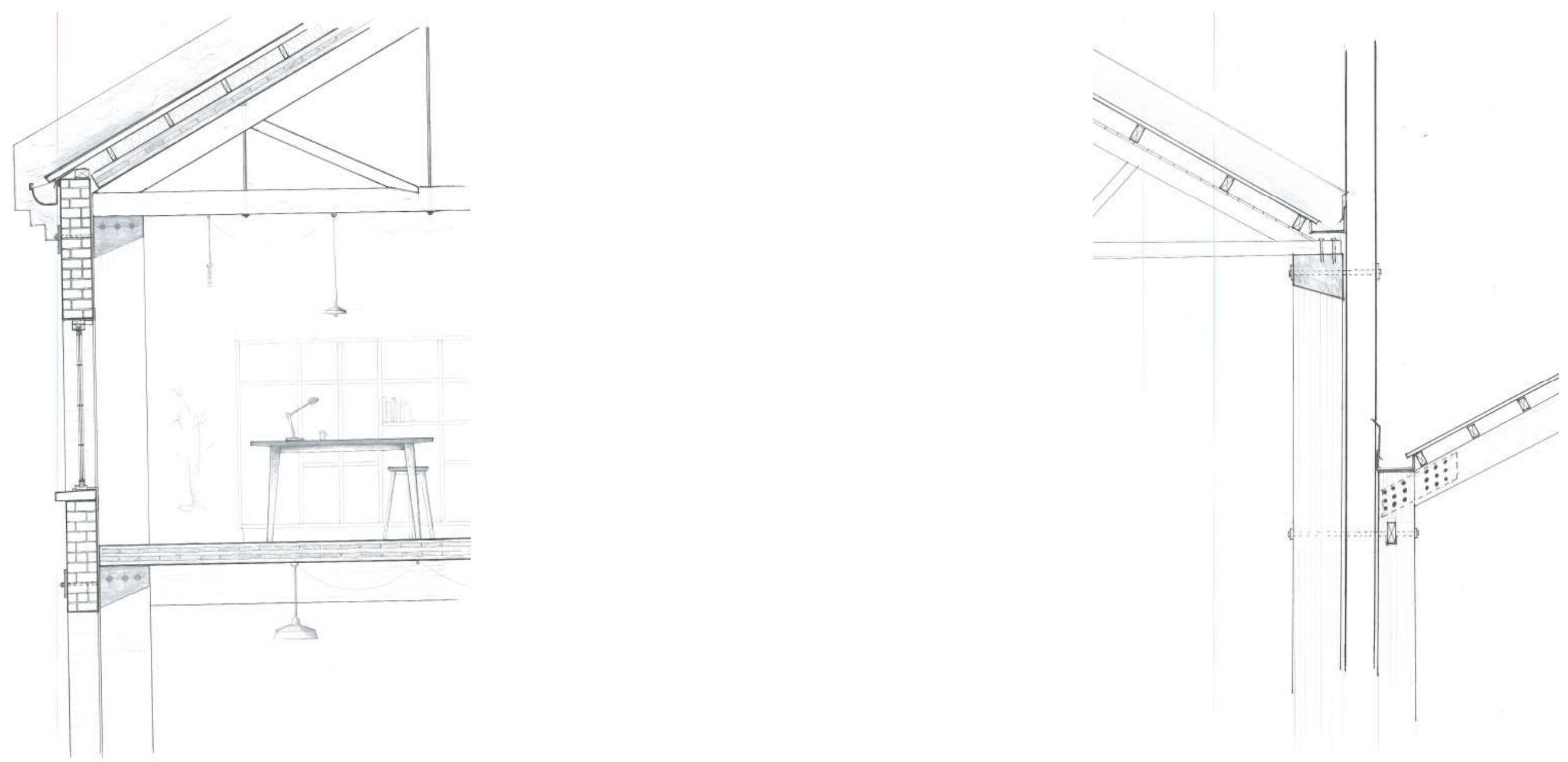


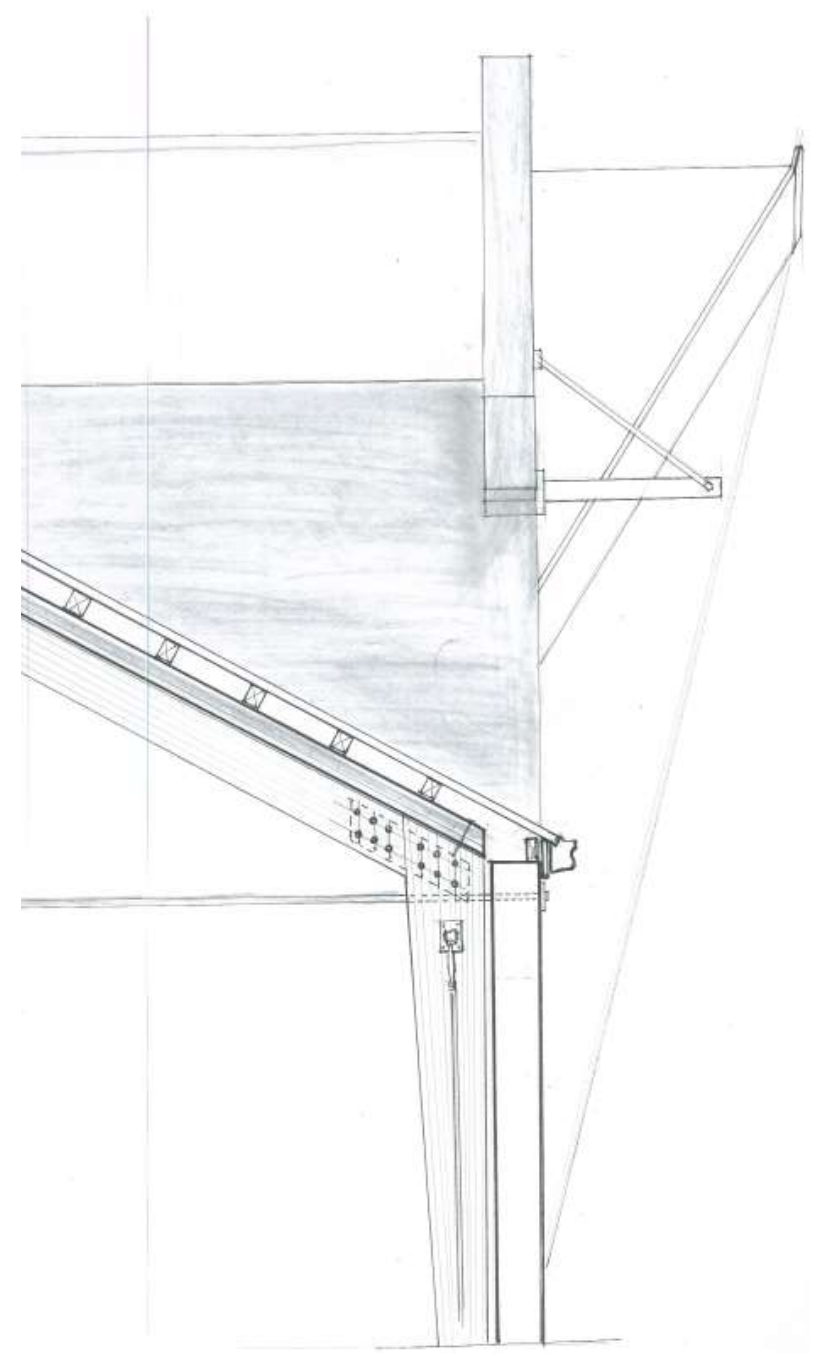

Figure 204 Glulam frame with C.L.T roof diaphragm next to single storey U.R.M wall.

Source: Author's Image 


\subsection{Exegesis}




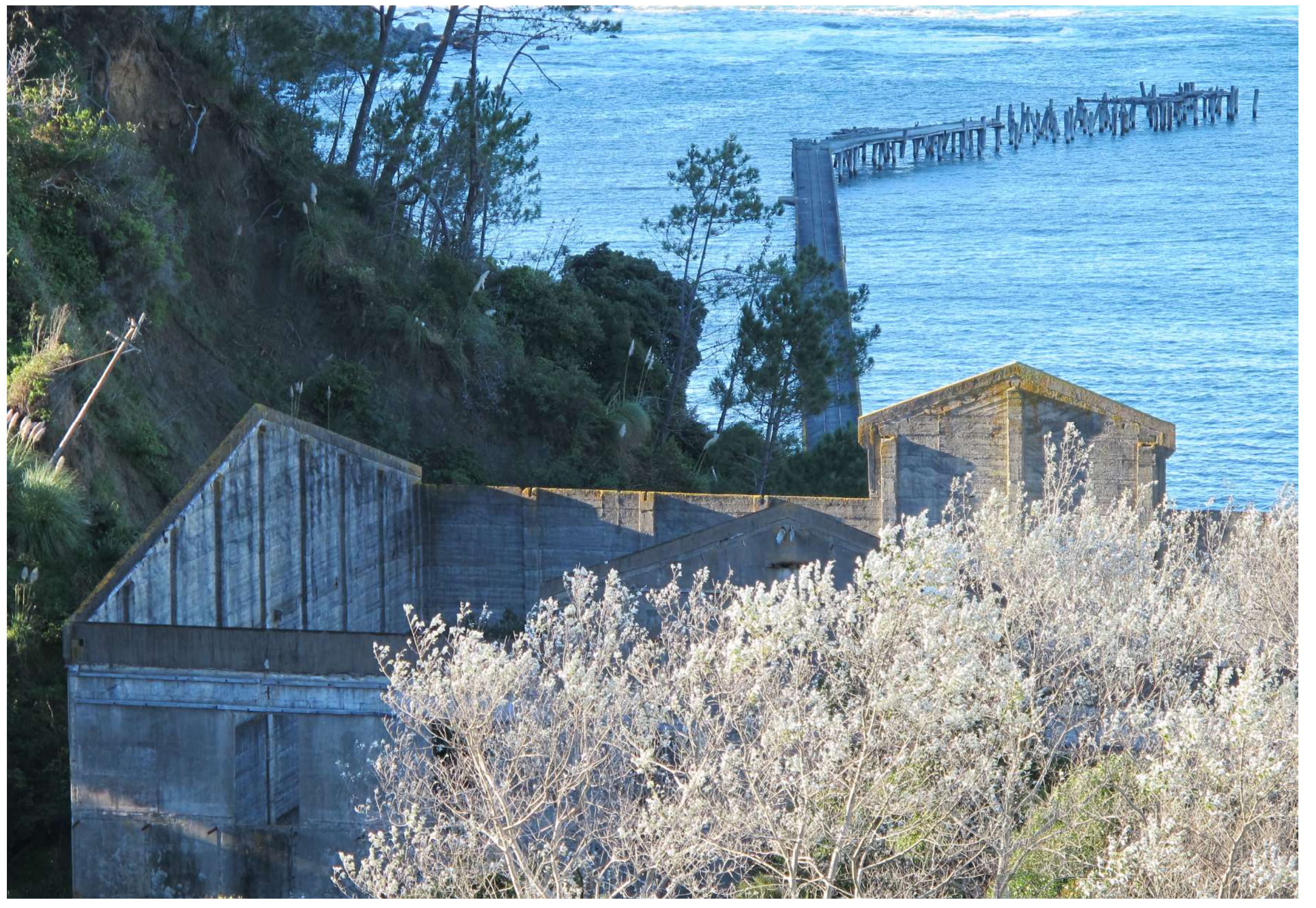




\subsection{Introduction}

This chapter reflects on how the case study has responded to the original research question:

How can laminated timber be used in the adaptive reuse of unreinforced masonry industrial heritage buildings in rural New Zealand?

The performance of the case study is measured by analysing the final design against the guidelines developed through the research to see whether the case study meets the 5 design criteria: character, structure, heritage, envelope and structure.

\subsection{Suitability of Case Study}

Tokomaru Bay is a suitable site to explore the research question because it is a typical example of U.R.M industrial heritage in a region that is struggling for relevance in the 21st century.

Manuka honey programme is a suitable programme, as it is respectful of the heritage of the site, and it contributes positively to Tokomaru Bay and the wider East Coast region.

Only site visit was made (April 2017), this provided site and context analysis of the site and Tokomaru Bay area and allowed a programme to be selected. It would have been very beneficial to visit the site again during the concept/development stage of the case study, this would have led to a more highly resolved design.

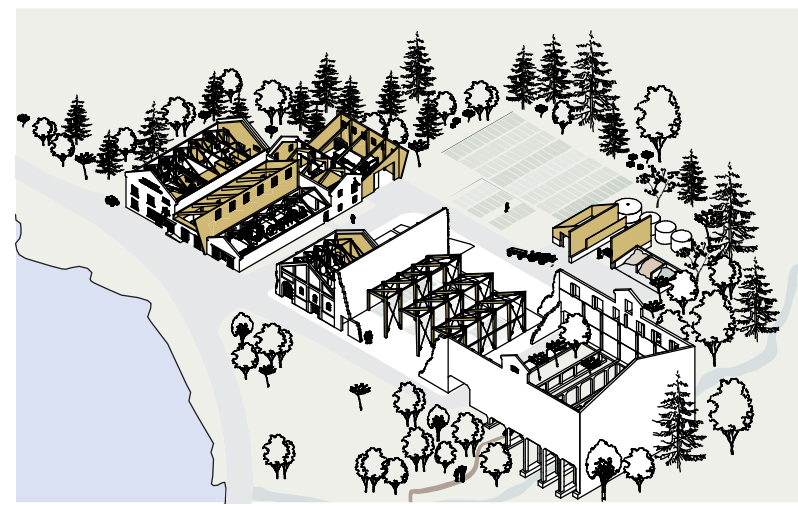

Figure 206 Tokomaru Bay Honey Co-operative axonometric. Source: Author's Image

\subsection{Overall Design Approach}

The design response could be regarded as low-key, as there was no need for a large architectural gesture as that would have been too dominating over the existing heritage. The final design is a more considered outcome that respects the site. Laminated timber did not contribute to this design move, but it does help to differentiate between old and new components of the adaptive reuse.

The case study tests the application of laminated timber in a number of ways such as:

- Glulam inserted within masonry (packing house).

- C.L.T within masonry (extraction and offices, visitors centre).

- New C.L.T building (loading bay).

- New glulam building (propagation).

The application of laminated timber ranges across the four main areas: honey factory, manuka nursery, visitors centre and ruins.

The honey factory is the most highly resolved area. The production component of the honey factory, which consists of the storage, extraction and packing area, remains open plan, which suits the existing nature of the industrial space.

The offices, by-products and back of house areas require more intimate spaces. Laminated timber is used to scale down the large industrial space into more habitable sizes appropriate for its new use. 


\subsection{Design Assessment}

This section evaluates the case study against each of the design guidelines (see page 146-147 for final design guidelines).

The guidelines have been separated into the 5 design criteria categories.

Where a design strategy has been implemented to help meet the design guideline it has been referenced at the bottom.

\subsubsection{Character}

\section{1a. Form}

The new geometry introduced from the orientation of the wharf in the initial concept has been carried through the design to distinguish old and new. Where new structures have been designed a mono-pitch roof has been used, where an existing space has been preserved the original gable roof has been retained. This distinguishes old and new.

[strategy 13 - offset roof pitch]

[strategy 20 - new geometry]

\section{1b. Identity}

While respecting the heritage of the building, the design response aims to recognised and celebrate the adaptive reuse of the building, signifying the start of a new chapter for the site.

The exterior masonry facade has been left intact, and through the existing openings and the angular protrusions laminated timber is visible. The introduction of this new material in the existing site signifies that there is a new use for the building.

\section{1c. Scale}

The case study has explored the U.R.M and laminated timber at a range of scales. Laminated timber is used to scale down large industrial spaces into zones more appropriate for honey production.

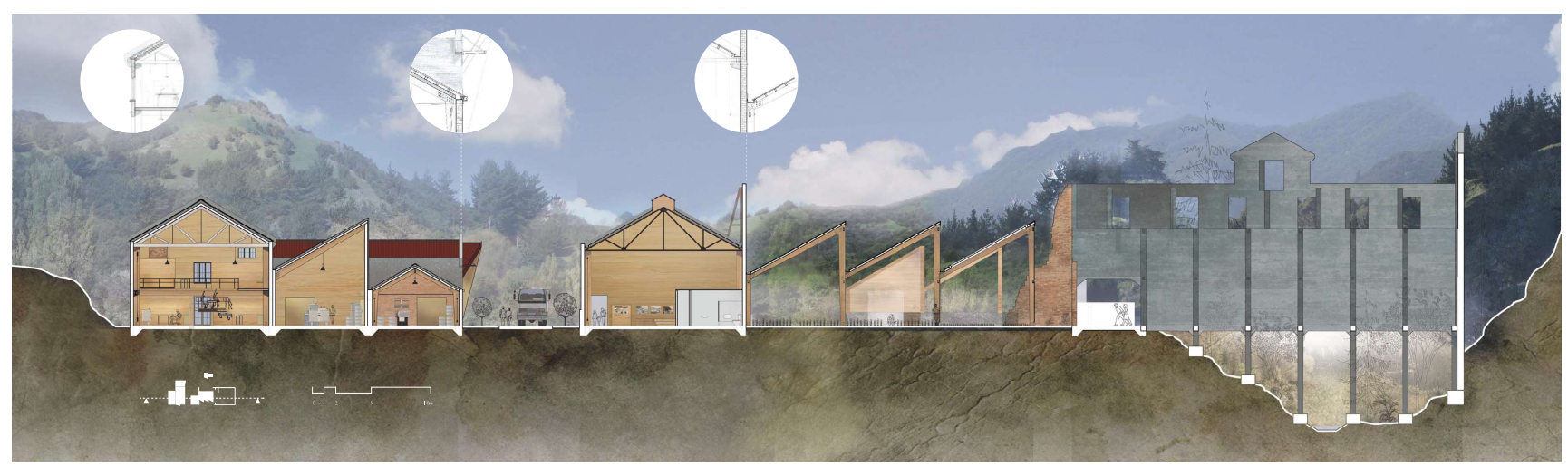

Figure 207 Mono-pitch roof forms indicate what is new and 


\subsection{Design Assessment}

\subsubsection{Structure}

\section{2a. Strengthening}

The main structural requirement of laminated timber is to seismically strengthen existing masonry. Laminated timber used to seismically strengthen U.R.M by transferring lateral loads:

- C.L.T floor diaphragms

- C.L.T roof diaphragms

- C.L.T shear walls

- Glulam portal frames

[strategy 17 - structural laminated timber]

\section{2b. Structural Integration}

Structural integration is achieved by aligning the laminated timber structural grid with the existing masonry structural grid. Existing roof trusses meet new glulam beams.

[strategy 17 - structural laminated timber]

\section{2c. Structural Expression}

Laminated timber structure is expressed through the design. Structural timber elements such as portal frames and glulam beams are located on the structural grid at intervals throughout the building. The industrial scale of the room is reduced by the bays created between portal frames, this also allows the existing masonry to remain visible.

The use of portal frames allows heritage significance of the building to be expressed by allowing the existing masonry to remain visible. The industrial scale of the room is reduced by bays between the portals which are spaced through the building.

[strategy 17 - structural laminated timber]

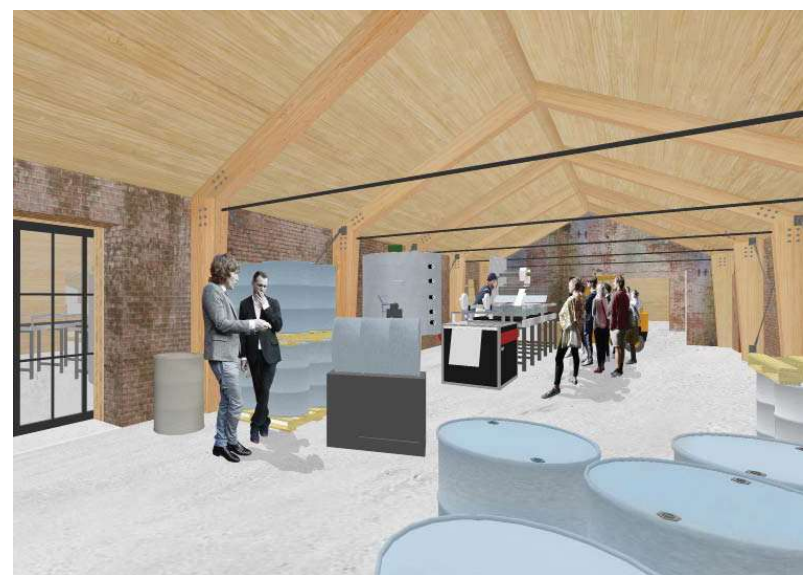

Figure 208 Existing masonry is visible between portal frames. Source: Author's Image

\subsubsection{Heritage}

3a. Understand and Acknowledge

Adaptive reuse requires the significance of a heritage site to be established before any design work is completed. This was done in the site analysis chapter.

Part of the design response was to leave part of the freezing works in its current state as ruins. This shows the historical highs and lows of the site when visitors walk through the site.

[strategy 19 - portion of a site]

\section{3b. Reversible Changes}

No irreversible changes to the existing heritage ruins have been proposed. As laminated timber is inserted within the existing ruins, it can just as easily be removed in the future if need be. 


\section{3b. Context}

The existing masonry envelope has been retained to preserve relationship between the building and its site.

\section{[strategy 7 - visible masonry]}

\section{3d. Reveal Significance}

The adaptive reuse process should be able to reveal the important heritage aspects of the site. The design response can account for this in several ways.

- The freezing chamber extension has been left as a ruin on site to continue its decay.

- The garden nursery is located on the concrete footprints of the buildings that have been demolished.

- Openings are created within interior C.L.T walls to reveal masonry behind.

[strategy 7 - visible masonry]

[strategy 12 - masonry left in ruins]

[strategy 19 - portion of site]

\section{3e. Add Significance}

The new programme contribute to the heritage of the site in the future by adding a new chapter in its history. The former state of the site as a freezing works and then a ruin remains legible in the final design.

The introduction of a new material to enable a new programme is an effective way to distinguish the changes that have occurred on site.

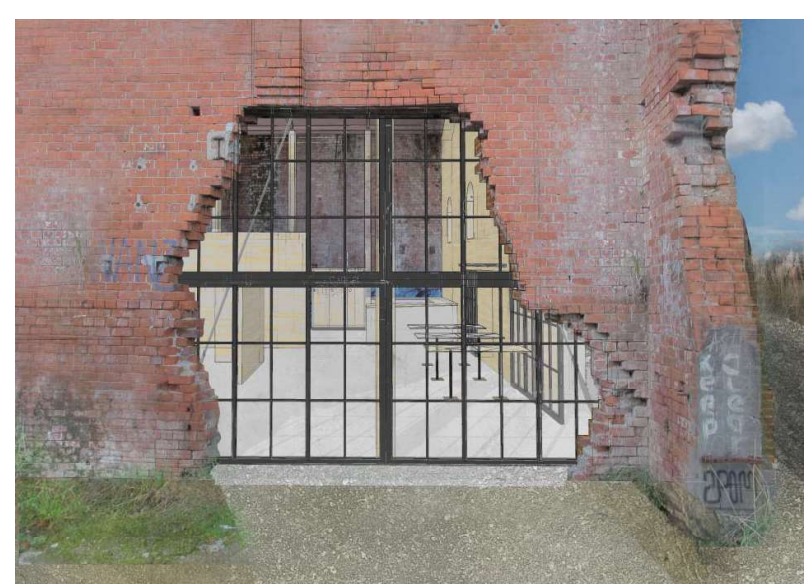

Figure 209 Adaptive reuse of ruins shows layers of history. Source: Author's Image

\subsubsection{Building Envelope}

\section{4a. Reinstate Envelope}

New exterior joinery is required in the existing openings of the envelope.

High windows that allow daylight into the building have been included where possible. Clerestory lights, orientated away from the north were used instead of skylights which would have let direct sunlight.

[strategy 1- light from above]

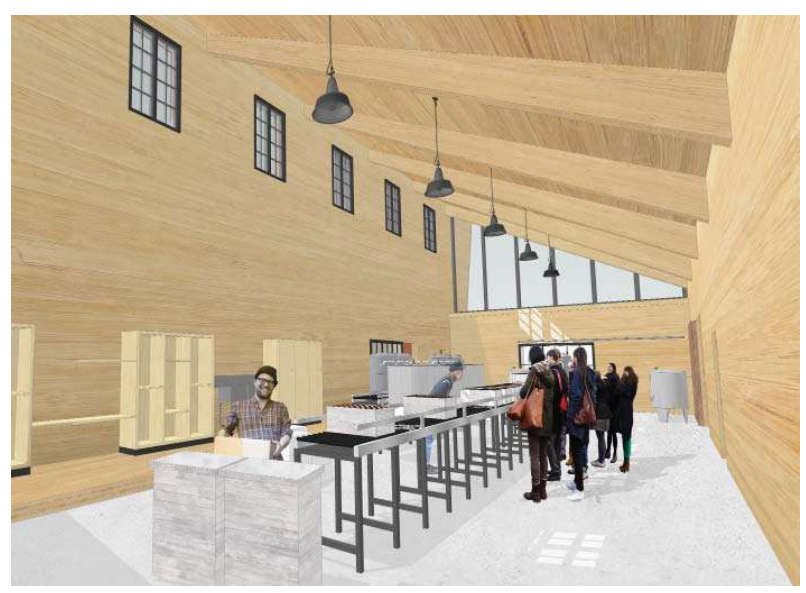

Figure 210 High windows allow day light into internal spaces. Source: Author's Image 


\subsection{Design Assessment}

\subsubsection{Building Envelope}

\section{4b. Front/Back}

The main honey processes of extraction, filtration and packaging, as well as the by products have been located at the front of the site and are visible through openings in the envelope. Deliveries and loading of trucks is located at the rear of the factory.

\section{4c. Public/Private}

The visitors centre has been located adjacent to the honey factory, but in a separate building.

The layout of the honey has the back of house area and offices segregated from the main factory floor.

\section{4d. Permeability}

The existing openings in the exterior envelope have been retained to maximize permeability between inside and outside of the new honey factory. This promotes that the building has a new use and allows the laminated timber to be seen from the exterior.

Large glass sliding doors with two leafs', one glazed the other solid timber were retrofitted to existing openings along the street frontage. This allows a changing relationship depending on the time of day between the interior and exterior (whether the solid doors are closed, the glass doors are closed, or both sets are open).

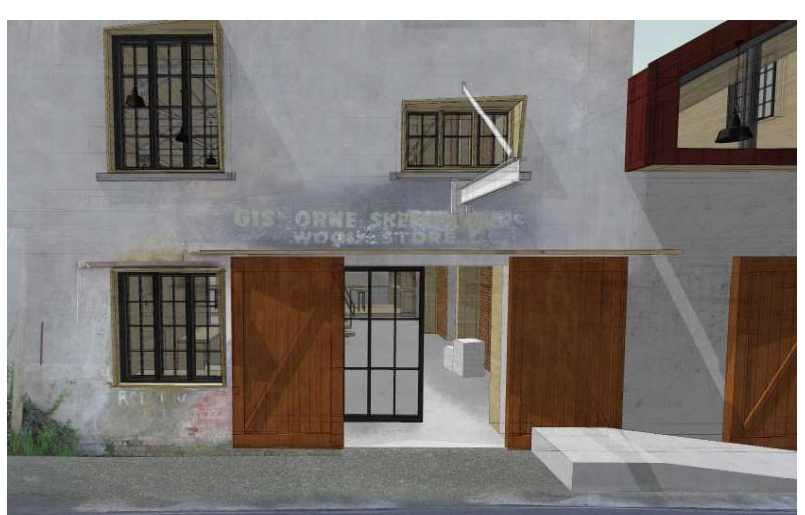

Figure 211 Openings that impact user interaction between inside and out.

Source: Author's Image

\section{4e. Weather tightness}

A standing seam metal roof profile wraps around the laminated timber roof and walls.

The mono-pitch roofs have created several internal gutters in the design which can be problematic.

Where masonry and C.L.T are adjacent there may need to be a cavity between the two materials. Details exploring the junction between laminated timber and masonry could have been more highly resolved

\section{4f. Security}

Large barn style sliding doors have been included to keep the honey factory secure outside of business hours. This enables the facility to be locked down. 


\subsection{Conclusion}

\subsubsection{Programme}

\section{5a. Selection}

Chapter four selected a programme that was appropriate to the heritage significance of the site and that could be implemented using laminated timber.

The honey factory does not require a specialised building. It does require specific zones, but these can be adapted from existing spaces.

The similarities between honey and laminated timber are complementary to each other.

\section{5b. Function}

Laminated timber was used to enable the new programme to function within the existing U.R.M walls.

C.L.T panels in the honey extraction room create a controlled environment. However, they do create create large flat walls (see figure 210), which is good from a functional sense, but the architectural result is uninspiring and sanitised. Use of portal frames to break up the sameness of the walls would have made this space more appealing to inhabit.

The introduction of a C.L.T mezzanine floor allows for multiple zones in the same building. The large industrial space is divided with honey by-products below and office space above.

[design strategy 3 - aligned walls]

[design strategy 18 - change in floor height]

\section{5c. Versatility}

The spaces within the honey factory are not specialised, allowing for versatility, and potentially a change of use in the future.

Laminated timber is located around the periphery of the existing interior walls preserving large uninterrupted spaces.

The size of the freezing works site also allows for growth and expansion in the future as shown in the master plan.

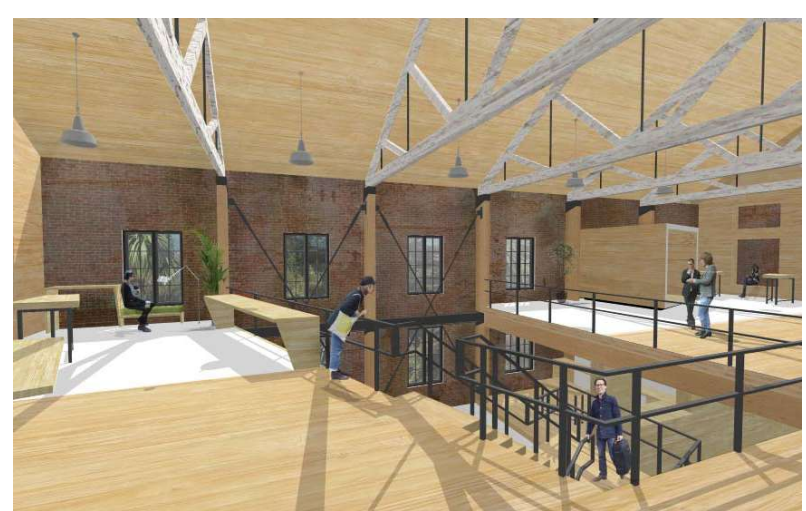

Figure 212 Laminated timber enabling new program to occur. Source: Author's Image
The case study has explored the research question by responding to the 5 key criteria (character, structure, heritage, envelope and programme).

Overall the case study had met the design guidelines to create a successful example of adaptive reuse that incorporates laminated timber and U.R.M. 


\subsection{Conclusion}




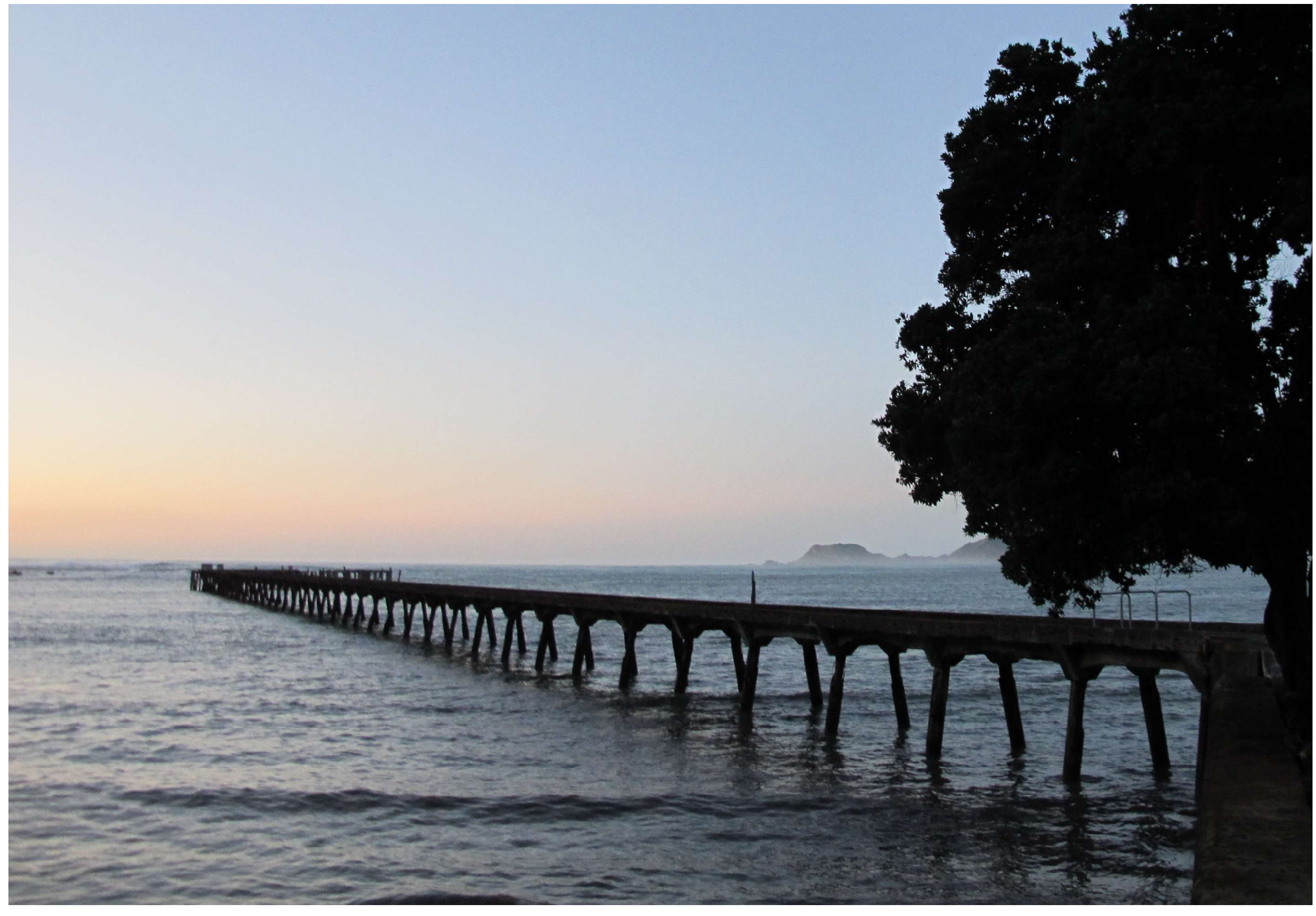




\subsection{Introduction}

This chapter concludes the design research by reiterating key findings, commenting on the methodology, limitations and applications of the research, and finally a closing statement.

\subsection{Key Findings}

\subsubsection{Industrial Heritage}

Rural townships have historically been reliant on one industry as the main employer, and the prosperity of that community is directly affected by that industry. Through the research it became clear that finer examples of industrial heritage are likely to be found outside of urban areas as there is less pressure for the land to be reused. For example, as freezing works located in urban areas were demolished, the heritage value of rural freezing works increases. These sites are at risk of being lost, due to their location they are largely forgotten by the public.

\subsubsection{Adaptive Reuse}

Adaptive reuse is one method of heritage conservation and not all heritage is appropriate for adaptive reuse. Heritage sites need to be analysed on a case by case basis as to which conservation strategy is the most suitable.

Industrial heritage sites can be suitable for adaptive reuse as buildings have outlived their original purpose.

\subsubsection{Laminated Timber}

Precedents identified show that laminated timber has been used in a small number adaptive reuse heritage projects overseas.

Laminated timber was only used for internal applications. C.L.T cannot be exposed to the exterior in New Zealand and needs an exterior cladding with a cavity system. Treated L.V.L and glulam is available, but ingress of water is likely to cause the laminations to separate as a result laminated timber was used for interior applications in this research.

Use of laminated timber on the interior allows the existing heritage exterior of the building to remain visible preserving the relationship of the building within its context.

Laminated timber is made visible from the exterior to hint that the heritage building has been adaptively reused.

Use of C.L.T panels to create large flat surfaces needs to be considered as it does not allow the heritage of the site to be expressed in the design.

Use of laminated timber means that no irreversible changes are made to the existing heritage fabric during adaptive reuse. 


\subsection{Research Reflection}

\subsubsection{Research Methodology}

The research identified and developed design strategies that implemented laminated timber through six design iterations that led to the development of the final case study. This was then analysed against the design guidelines that were formulated through the research process.

A higher level of detail, and testing of the practical application of how laminated timber can be installed on heritage sites would give more weight to the research.

\subsubsection{Research Limitations}

To narrow the scope of the research, only freezing works were considered as industrial heritage. There are heritage sites from a range of industries around New Zealand (e.g. dairy factories and mining) and the application of laminated timber through adaptive reuse of these sites remains untested.

\subsubsection{Design Guidelines}

The design guidelines evolved throughout the research, they were deliberately developed in a way that promotes the five criteria (character, structure, heritage, envelope and programme) and enabled them to be addressed rather than acting as prohibitive measures.

The guidelines are not exhaustive, and more could be added to the list through other design case studies.

\subsection{Closing Statement}

\subsubsection{Applications of the Research}

The aim of the research was to produce a set of design guidelines that could be used by designers to inform how laminated timber is used in future U.R.M industrial heritage adaptive reuse projects. The guidelines will help designers determine a level of change that is appropriate to heritage sites when considering adaptive reuse.

While the research focused on industrial heritage in rural New Zealand, the design guidelines are applicable to any adaptive reuse project that incorporates strengthening of U.R.M heritage buildings, both urban and rural.

\subsubsection{Further Research}

Research exploring the structural capabilities of laminated timber as a material for earthquake strengthening of U.R.M buildings would complement this research. There is also opportunity for further research to be conducted on how lateral loads are transferred from U.R.M to laminated timber.

A feasibility study that compares the differences in cost between laminated timber and other typical seismic strengthening techniques would also be beneficial to the viability to the use of laminated timber in heritage buildings.
This research explores a new application for the use of laminated timber in New Zealand and promotes its use as an alternative response to how U.R.M heritage buildings are typically approached.

Around the world, many countries are revered for their built heritage of castles and monasteries that is hundreds of years old; New Zealand is a young country without such buildings. New Zealand's rapid growth was paired to the development of early industries, these sites will be of major significance in the future, but for them to survive there needs to be recognition now. The treatment of heritage buildings requires careful navigation with many factors in play. Laminated timber provides a great opportunity for how postindustrial architecture could be approached in New Zealand, but it will require the necessary parties to be pro-active and bold. 


\subsection{Design Guidelines}

\begin{tabular}{|l|l|l|}
\hline Criteria: & $\begin{array}{l}\text { 1. Character } \\
\begin{array}{l}\text { Positive formal relationship between } \\
\text { laminated timber and U.R.M. }\end{array}\end{array} \quad \begin{array}{l}\text { 2. Structure } \\
\text { Laminated timber to seismically strengthen } \\
\text { U.R.M. }\end{array}$ \\
\hline
\end{tabular}

\begin{tabular}{|c|c|c|}
\hline Principles: & $\begin{array}{l}\text { 1a. Form } \\
\text { Establish a formal relationship that } \\
\text { achieves a unified composition while also } \\
\text { distinguishing between laminated timber } \\
\text { and U.R.M. } \\
\text { 1b. Identity } \\
\text { Laminated timber should be identifiable } \\
\text { from the exterior to identify the buildings } \\
\text { new use. } \\
\text { 1c. Scale } \\
\text { Ensure design strategies address three } \\
\text { distinct scales: } \\
\text { 1. Large. Re-scale of large industrial site } \\
\text { for inhabitation of new programme. } \\
\text { 2. Medium. Retain simplicity and } \\
\text { industrial grandeur of existing } \\
\text { buildings. } \\
\text { 3. Small. Retain trace of industrial } \\
\text { heritage in new design at a detail level }\end{array}$ & $\begin{array}{l}\text { 2a. Strengthening } \\
\text { Laminated timber to provide adequate } \\
\text { structural support to existing U.R.M. } \\
\text { 2b. Structural Integration } \\
\text { Structural laminated timber elements } \\
\text { are integrated with structural masonry } \\
\text { elements. } \\
\text { 2c. Expression } \\
\text { Express structural laminated timber } \\
\text { elements visually in the design response. }\end{array}$ \\
\hline
\end{tabular}




\begin{tabular}{|l|l|l|}
$\begin{array}{l}\text { 3. Heritage } \\
\begin{array}{l}\text { Retain and enhance significance of heritage } \\
\text { site. }\end{array}\end{array} \quad \begin{array}{l}\text { 4. Envelope } \\
\text { Re-establish building envelope. }\end{array}$ & $\begin{array}{l}\text { 5. Programme } \\
\text { Laminated timber facilitates introduction } \\
\text { of new production activity. }\end{array}$ \\
\hline
\end{tabular}

\section{3a. Understand + Acknowledge}

Understand the significance of the U.R.M industrial heritage site before designing. Determine a level of change that acknowledges the significance of the site.

\section{3b. Reversibility}

Allow for the changes within the site to be reversed (this allows the opportunity for future interpretations of the heritage.

\section{3c. Context}

Conserve relationship between the U.R.M industrial heritage building and its setting. This preserves significant views to and from the U.R.M industrial heritage site.

\section{3d. Reveal Significance}

Reveal and interpret the heritage of the site through adaptive reuse.

\section{3e. Add Significance}

Introduce a program that builds on the existing heritage of the site and contributes to the heritage of the site in the future.

\section{4a. Reinstate envelope}

Reinstatement of building envelope (currently in ruins).

\section{4b. Front/Back}

Preserve masonry frontage, separate front of house and back of house.

\section{4c. Public/Private}

Consideration of the different needs of public and private user groups when accessing the building.

\section{4d. Permeability}

Provide openings along exterior envelope that visually promote laminated timber and indicate the new program within existing U.R.M building.

\section{4e. Weather-tightness}

Address weather tightness between new and old.

\section{4f. Security}

Provide secure facilities within heritage site.

\section{5a. Programme Selection}

Select a program that allows the U.R.M industrial heritage site to be adaptively reused.

\section{5b. Function}

Use laminated timber to meet individual spatial requirements of new program within U.R.M site.

\section{5c. Versatility}

Allow for future expansion and development of the site. Buildings should be adaptable enough allowing future change in use. 
9.0 References, Figures and Appendices 

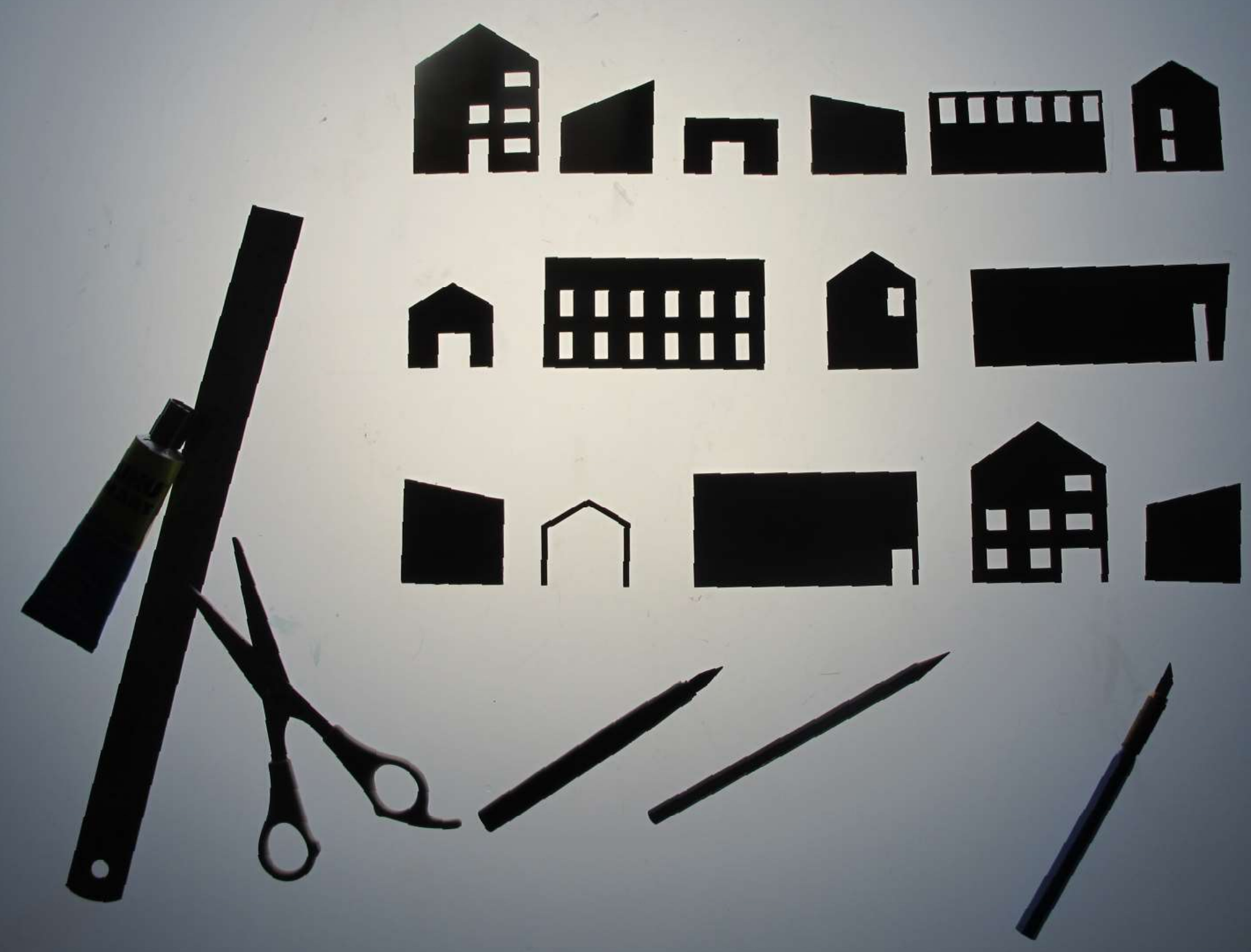


\subsection{References}

Bejder, A. K. Aesthetic Qualities of Cross Laminated Timber. Aalborg: Aalborg University, 2012. Document.

Bullen, Peter; Love, Peter. The Rhetoric of Adaptive Reuse or Reality of Demolition: Views form the field. School of the Built Environment, Curtin University of Technology. Perth. 2009. Document. <http://www.sciencedirect.com/science/article/pii/S0264275109001450)>.

Clarke, Justine. “Adaptive Re-use of Industrial Heritage ." Heritage Council Victoria (2013).

Comvita. Manuka Honey: From the hive tot he shelf, trust Comvita UMF Mankuka Honey. 2017. Website. 21 June 2017. <http://www.comvita.co.nz/key-ingredients/manuka-honey/nz100008>.

Cramer, Johannes and Stefan Breitling. Architecture in Existing Fabric. Berline: Birkhauser, 2007. Print. Goodwin, Cass, Garrick Tonks and Jason Ingham. "Identifying Heritage Value in URM Buildings." Structural Engineering Society New Zealand 22.2 (2009): 16-28. Document.

Gundry, Sheridan. Making a Killing: A history of the Gisbourne-East Coast freezing works industry. Gisbourne: Tairawhaiti Museun, 2004. Print.

Harrison, Stuart, et al. Adaptive Re-use: Re-using existing buildings for new functions has many sustainable, cultural, econmic and place making advantages. Design Guidance Note. Adelaide: ODASA, 2014. Document. <file://fadstocoiscifs1/homedata\$/lovelomark/Desktop/ her-conservation-adaptive-reuse-guide-odasa.pdf $>$.

Heritage Council of New South Wales. "New Uses For Heritage Places." 2008. NSW Office of Environment and Heritage. Document. 8 July 2017. <http://www.environment.nsw.gov.au/ resources/heritagebranch/heritage/NewUsesforHeritagePlaces.pdf $>$.

Heritage New Zealand. Tokomaru Bay Wharf. Web. <http://www.heritage.org.nz/the-list/details/3565>.

-. New Uses For Heritage Places: Guidelines for the Adaption of Historic Buildings and Sites. Sydney, 2008. Document. 19 June 2017.

ICOMOS New Zealand. ICOMOS New Zealand Charter. 2010. Website. 18 June 2017. <http://icomos. org.nz/wp-content/uploads/2016/08/NZ_Charter.pdf>. 
Ministry for Primary Industries. Mānuka Honey. 2017. Website. 18 June 2017. <http://www.mpi.govt. nz/growing-and-producing/bees-and-other-insects/manuka-honey/>.

Morrison, Tina. NZ honey exports soar 41\% in 2015 to new record. 1 February 2016. Website. 21 June 2017. <https://www.nbr.co.nz/article/nz-honey-exports-soar-41-2015-new-record-b-184226>.

Powell, Kenneth. Architecture Reborn: The conversion and reconstruction of old buildings. London: New Line Books, 1999. Print.

Robert, Philippe. Adaptions: New uses for old buildings. New York: Princeton Architectural Press, 1989. Print

Smith, Nigel. Heritage of Industry: Discovering New Zeland's Inudstrial History. Auckland: Reed Publishing, 2001. Print.

Statistics New Zealand. "2013 Census QuickStats about a place:." n.d. Statistics New Zealand. Website. 29 June 2017. <http://www.stats.govt.nz/Census/2013-census/ profile-and-summary-reports/quickstats-about-a-place.aspx?request_value $=13995 \&$ parent_id=13992\&tabname=\#13995>.

Thornton, Geoffrey G. New Zealand's Industrial Heritage. Wellington: Reed Publishing, 1982. Print.

Tolerton, Jan. Agricultural Processing Industries - Freezing Works, 1880s to the 1970's. Te Ara - the Encyclopedia of New Zealand. <https:/teara.govt.nz/en/photograph/25188/soloslaughtermen>.

Walker, Meredith and Peter Marquis-Kyle. The Illustrated Burra Charter; Good Practice for Heritage places. Melbourne: Troedel \& Co, 2004.

XLam. About XLam CLT: What is Cross Laminated Timber? 2017. Web. 3 July 2017. <http://www. xlam.co.nz/xlam-clt.html>.

XLam. Designing with XLam Cross Laminated Timer: New Zealand Design Guide Version 2.1. Nelson, September 2016. Document. 


\subsection{List of Figures}

Figure 1 Waipaoa freezing works. Author's Image

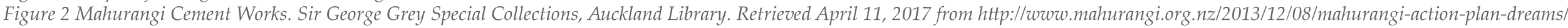

Figure 3 Mojo Coffee roastery. Paul McCredie. Retrieved February 18, 2018 from https://trendsideas.com/article/in-good-taste-new-zealand

Figure 4 Olpererhü̈te. Hermann Kaufmann. Retrieved March 28, 2017 from http://www.hermann-kaufmann.at/projekt/olpererhuette/

Figure 5 Research methodology diagram. Author's Image.

Figure 6 Sunrise at Tokomaru Bay. April 2017. Author's Image.

Figure 7 Tokomaru Bay woolstore. April 2017. Author's Image.

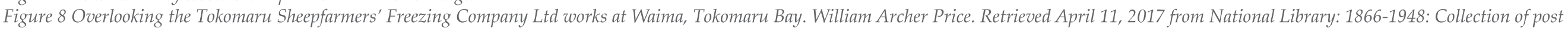
card negatives. Ref: 1/2-000943-G. Alexander Turnbull Library, Wellington, New Zealand. /records/22856613

Figure 9 Remains of the Tokomaru Bay manure works. April 2017. Author's Image.

Figure 10 Demolition of Kaiti Freezing Works, Gisborne. Retrieved February 13, 2018 from The Gisborne Herald.

Figure 11 Solo Slaughtermen at Whakatu Freezing Works, Hastings. 1919. Retrieved March 15, 2017 from Alexander Turnbull Library.

Figure 12 Butchers on a killing chain system. 1939. Retrieved March 5, 2017 from Alexander Turnbull Library.

Figure 13 Aerial view of the sprawling Kaiti Freezing Works, circa 1940. Retrieved March 15, 2017 from Tairawhiti Museum.

Figure 14 Steel Portal Structure, Hill Road. CASE. Retrieved December 13, 2017 from http://www.civilandstructuralengineering.com/about us.htm

Figure 15 Shotcrete being applied to masonry wall. Epidomos Ltd. Retrieved December 13, 2017 from http://www.epidomos.gr/gunite.php?id=47Elang=1

Figure 16 Fibre reinforced polymer reinforcing. Tarek Alkhrdaji. Retrieved December 13, 2017 from http://www.structuremag.org/? $p=8643$

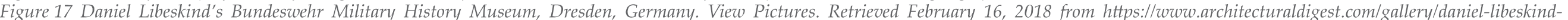
architecture/all

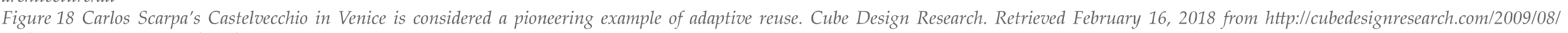
authenticity-scarpas-castelvecchiol

Figure 19 Cement factory conversion by Ricardo Bofill. DOMUS. Retrieved February 16, 2018 from http://loves.domusweb.it/la-fabrical

Figure 20 Cement Factory,1973. Ricardo Bofill, Retrieved February 16, 2018 from http://www.ricardobofill.com/la-fabrica/read/

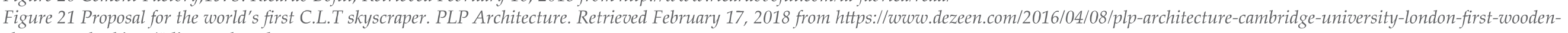
skyscraper-barbican/\#disqus_thread

Figure 22 C.L.T Cross-section. Author's Image.

Figure 23 L.V.L Cross-section. Author's Image.

Figure 24 Glulam Cross-section. Author's Image.

Figure 25 C.L.T house in Austria. KLH. Retrieved February 17, 2018 from http://www.architectureanddesign.com.au/features/features-articles/get-ready-for-the-cross-laminated-timber-clt-revol

Figure 26 L.V.L in College of Creative Arts, Wellington. Nelson Pine. Retrieved February 17, 2018 from http://www.nelsonpine.co.nz/wp-content/uploads/NelsonPine-LVL-Brochure-web.pdf

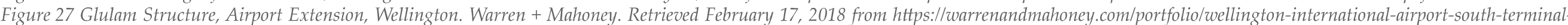
expansion

Figure 28 Peeping into the ruins of the Tokomaru Bay Freezing Works. April 2017. Author's Image.

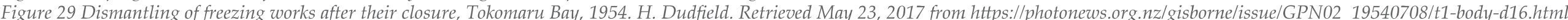

Figure 30 C.L.T North Island. Author's Image.

Figure 31 East Coast. Author's Image.

Figure 32 Tokomaru Bay. Author's Image.

Figure 33 Waima Cove. Author's Image.

Figure 34 Typical East Coast views, regenerating bush on soft soiled, steep hillside. April 2017. Author's Image.

Figure 35 Mānuka bush regenerating on farmland above Tokomaru Bay. April 2017. Author's Image.

Figure 36 Looking south along Tokomaru Bay. April 2017. Author's Image.

Figure 37 Tokomaru Bay town centre. April 2017. Author's Image. 
Figure 38 Tokomaru Bay freezing works at Waima, 1949. Retrieved March 15, 2017 from Tairawhiti Museum.

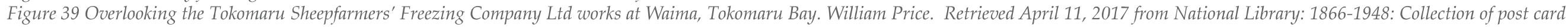
negatives. Ref: 1/2-000943-G. Alexander Turnbull Library, Wellington, New Zealand. Irecords/22856613

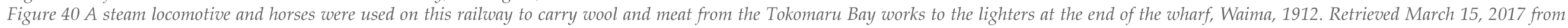
Tairawhiti Museum.

Figure 41 Trucks delivering wool to Waima in 1926, Barracks and store can be seen behind. Retrieved April 2, 2017 from Tairawhiti Museum.

Figure 42 Horse Stables, Waima Cove. Gisborne District Council. Retrieved January 27, 2018 fromhttp://www.heritage.org.nz/the-list/details/3478

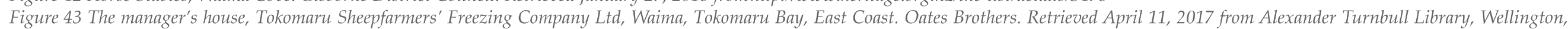
New Zealand. /records/22795147

Figure 44 Waima Cove Aerial. Tokomaru Bay Virtual Museum. Retrieved January 27, 2018 from http://www.tokomarubayvirtualmuseum.yolasite.com/waima.php

Figure 45 Tokomaru Bay Freezing Works, Waima Cove. April 2017. Author's Image.

Figure 46 Locals residents on the wharf, Waima Cove. April 2017. Author's Image.

Figure 47 Wool Store, Waima Cove. April 2017. Author's Image.

Figure 48 Horse Stables, Waima Cove. D Skinner, NZ Historic Places Trust. Retrieved January 27, 2018 from http://www.heritage.org.nz/the-list/details/3478

Figure 49 Harbourmaster's house, Waima Cove. April 2017. Author's Image.

Figure 50 Waima Cove 1952. Tokomaru Bay Virtual Museum. Retrieved July 27, 2018 from Tokomaru Bay Virtual Museum.

Figure 51 Waima Cove 2017. L.I.N.Z. Retrieved July 27, 2018 from https://www.linz.govt.nz/

Figure 52 The start of a 30,000 acre fire, lit to clear the land of bush, circa 1900s. Puketoro Station, East Coast. Frederick Hargreaves. Retrieved June 17, 2017 from Alexander Turnbull Library.

Figure 53 Bush Clearing - the first stage in pasture development The ravaged landscape is Mokoiwi Station, East Coast. Tairawhiti Museum. Retrieved June 17, 2017 from Tairawhiti Museum.

Figure 54 Sheep crossing the Mata River on Puketoro Station, early 1900's. Frederick Hargreaves. Retrieved June 17, 2017 from Alexander Turnbull Library.

Figure 55 The areas affected by erosion in Waiorongomai Gully, inland from Ruatoria, now covers 90 hectares. Ministry for Primary Industries. Retrieved June 17, 2017 from A Splendid Isolation.

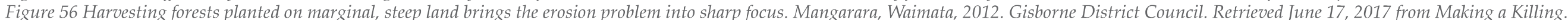

Figure 57 Poplar pole planting in the Turihaua Stream in 1979 on the left, the same gully on the right in 1987. Gisborne District Council. Retrieved June 17, 2017 from A Splendid Isolation.

Figure 58 Driving a mob of sheep at Waihau Beach. Tairawhiti Museum. Retrieved June 17, 2017 from Making a Killing.

Figure 59 Map of East Coast freezing works. Author's Image.

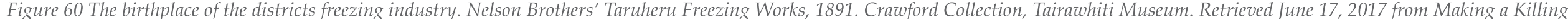

Figure 61 An aerial view of the sprawling Kaiti works, circa 1940. The freezing workers monument is visible on the hill. Tairawhiti Museum. Retrieved June 17, 2017 from Making a Killing.

Figure 62 Footing form the base of the smoke stack is all that remains of Taruheru works. April 2017. Author's Image.

Figure 63 Former Kaiti works converted to a restaurant. April 2017. Author's Image.

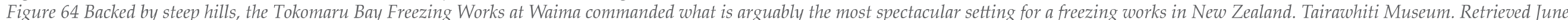
17, 2017 from Making a Killing.

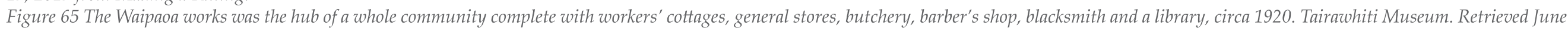
17, 2017 from Making a Killing.

Figure 66 Hicks Bay works in operation, early 1920s. Tairawhiti Museum. Retrieved June 17, 2017 from Making a Killing.

Figure 67 Tokomaru Bay Freezing Works sit dormant. April 2017. Author's Image.

Figure 68 Concrete structure remains of the Waipaoa Freezing Works dominates the landscape. April 2017. Author's Image.

Figure 69 Remains of the Hicks Bay works. Hayley Grace. Retrieved June 17, 2017 from https://talltalestravelblog.files.wordpress.com/2014/06/w_mg_9253.jpg

Figure 70 Site Plan and Building Footprint of Taruheru. Author's Image.

Figure 71 Site Plan and Building Footprint of Kaiti. Author's Image.

Figure 72 Site Plan and Building Footprint of Tokomaru Bay. Author's Image.

Figure 73 Site Plan and Building Footprint of Waipaoa. Author's Image.

Figure 74 Site Plan and Building Footprint of Hicks Bay. Author's Image. 


\subsection{List of Figures}

Figure 75 Aerial of Tokomaru bay Freezing Works ruins 2017. L.I.N.Z. Retrieved July 27, 2018 from https://www.linz.govt.nz/

Figure 76 Engine room interior. April 2017. Author's Image.

Figure 77 Engine room exterior. April 2017. Author's Image.

Figure 78 Local girl walking along the freezing chamber extension as seen from the stream. April 2017. Author's Image.

Figure 79 Manure works roof beginning to collapse. April 2017. Author's Image.

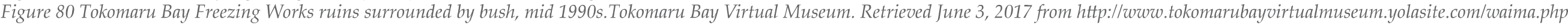

Figure 81 Tokomaru Bay Freezing Works ruins coastal outlook, 2017. April 2017. Author's Image.

Figure 82 Exterior treatment of masonry buildings. April 2017. Author's Image.

Figure 83 Existing openings in the former engine room. April 2017. Author's Image.

Figure 84 Masonry danger of collapse. April 2017. Author's Image.

Figure 85 Opening in the former engine room. April 2017. Author's Image.

Figure 86 Patch up repairs to an opening on the woolstore. April 2017. Author's Image.

Figure 87 Freezing chambers overgrown. April 2017. Author's Image.

Figure 88 Waima Cove site analysis. April 2017. Author's Image.

Figure 89 Tokomaru Bay site analysis. April 2017. Author's Image.

Figure 90 Tokomaru Bay Local Having a 'sort out' in the old woolstore. April 2017. Author's Image.

Figure 91 Interior of Tokomaru Bay woolstore, 2017. April 2017. Author's Image.

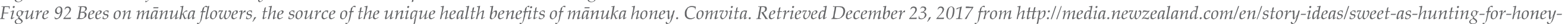
in-new-zealand/

Figure 93 Jar of the good stuff. Ryan Merce. Retrieved December 23, 2017 from http://www.abc.net.au/news/2017-09-15/jar-of-manuka-honey/8949570

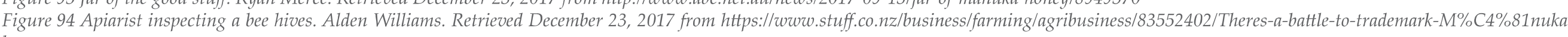
honey

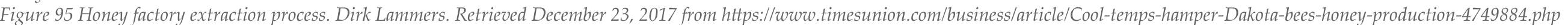

Figure 96 Kauri Park Mānuka Nursery. Tracey Robinson. Retrieved December 23, 2017 from https://www.kauriparknurseries.co.nz/kauri-park-expanding/

Figure 97 Typical Honey Factory Floor Plan. Alberta Agriculture. Retrieved December 23, 2017 from http://capabees.org/content/uploads/2013/02/HoneyHouseandEquipmentLayouts.pdf

Figure 98 Total hives in New Zealand (Apiculture NZ). Author's Image.

Figure 99 New Zealand annual honey exports. Author's Image.

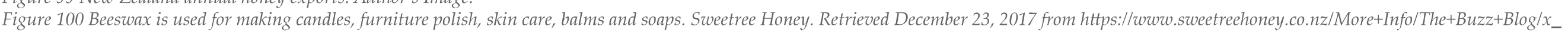
post/Products-of-the-hive-beeswax-00142.html

Figure 101 Bee pollen is rich in vitamins, minerals, proteins, lipids and fatty acids. Urbol. Retrieved December 23, 2017 from http://urbol.com/bee-pollen/

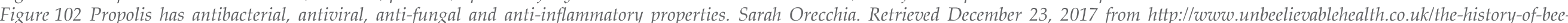
propolis-and-why-its-beneficial-to-human-health-2/

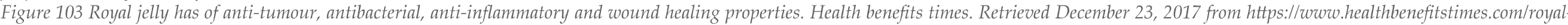
jelly-facts-and-health-benefits

Figure 104 Relationships within the research. Author's Image.

Figure 105 Tokomaru Bay wharf. April 2017. Author's Image.

Figure 106 Design iteration diagram. Author's Image.

Figure 107 S(ch)austal Insertion. FNP Architekten. Retrieved April 25, 2017 from https://www.apartmenttherapy.com/schaustall-by-fnp-architekten-89439

Figure 108 S(ch)austal exploded axonometric. Author's Image.

Figure 109 S(ch)austal insertion. Zooey Braun. Retrieved April 25, 2017 from http://www.tectonicablog.com/docs/tectonica_fnp_rehab\%20red.pdf

Figure 110 S(ch)austal interior. Zooey Braun. Retrieved April 25, 2017 from http://www.tectonicablog.com/docs/tectonica_fnp_rehab\%20red.pdf

Figure 111 Altered roof pitch between old and new. James Pallister. Retrieved April 25, 2017 from https://www.dezeen.com/2014/03/05/hugh-strange-architects-archive-farmyard-barn/ 
Figure 112 Architecture archive exploded axonometric. Author's Image.

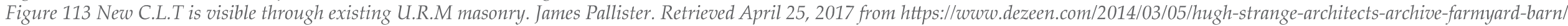

Figure 114 Architecture Archive interior. James Pallister. Retrieved April 25, 2017 from https://www.dezeen.com/2014/03/05/hugh-strange-architects-archive-farmyard-barn/

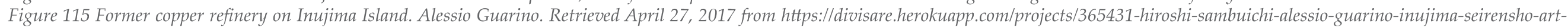
museum

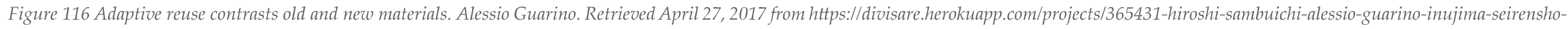
art-museum

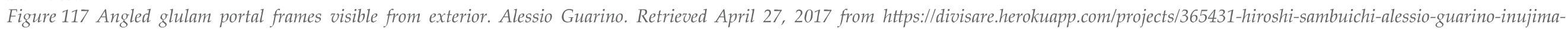
seirensho-art-museum

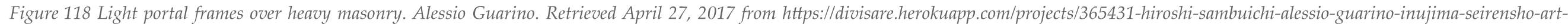
museum

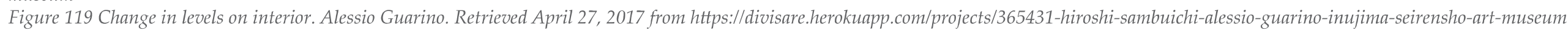
Figure 120 L.V.Linsertion into existing masonry shell. Zooey Braun. Retrieved April 25, 2017 from http://www.tectonicablog.com/docs/tectonica_fnp_rehab\%20red.pdf

Figure 121 Light from above. Author's Image.

Figure 122 Aligned openings. Author's Image.

Figure 123 Aligned walls. Author's Image.

Figure 124 Flooring. Author's Image.

Figure 125 Insertion. Author's Image.

Figure 126 Corner detail. Author's Image.

Figure 127 Visible masonry. Author's Image.

Figure 128 Architecture Archive. James Pallister. Retrieved April 25, 2017 from https://www.dezeen.com/2014/03/05/hugh-strange-architects-archive-farmyard-barn/

Figure 129 Half height masonry. Author's Image.

Figure 130 Offset window. Author's Image.

Figure 131 Restoration. Author's Image.

Figure 132 Concealed openings. Author's Image.

Figure 133 Masonry in ruins. Author's Image.

Figure 134 Offset roof pitch. Author's Image.

Figure 135 Offset opening. Author's Image.

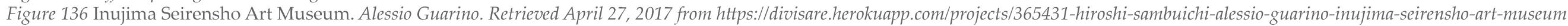

Figure 137 Light material above heavy material. Author's Image.

Figure 138 New addition. Author's Image.

Figure 139 Laminated timber as structure. Author's Image.

Figure 140 Change of floor height. Author's Image.

Figure 141 Portion of site used. Author's Image.

Figure 142 Introduce new geometry. Author's Image.

Figure 143 Design strategy collage. Author's Image.

Figure 144 Initial concept: freezing works and wharf geometries. Author's Image.

Figure 145 Existing rectilinear building footprints of Tokomaru Bay Freezing Works. Author's Image.

Figure 146 New laminated timber geometry laid over U.R.M geometry. Author's Image.

Figure 147 First attempt at how new laminated timber buildings combine with existing U.R.M. Author's Image.

Figure 148 Possible honey factory locations - slaughterhouse. Author's Image.

Figure 149 Possible honey factory locations - fellmongery. Author's Image. 


\subsection{List of Figures}

Figure 150 Possible honey factory locations - manure and tallow works. Author's Image.

Figure 151 Possible honey factory locations - engine, pump and boiler rooms. Author's Image.

Figure 152 Possible honey factory locations - freezing chamber. Author's Image.

Figure 153 Possible honey factory locations - freezing chamber extension. Author's Image.

Figure 154 Existing remains of manure $\mathbb{E}$ tallow works. Author's Image.

Figure 155 Existing openings in the industrial building. Author's Image.

Figure 156 Existing openings in the industrial building. Author's Image.

Figure 157 C.L.T wall set back from existing masonry wall. Author's Image.

Figure 158 Raised C.L.T floor changes the use of the space and promotes movement along the walkway. Author's Image.

Figure 159 C.L.T inserted within masonry exteriors. Author's Image.

Figure 160 Masonry visible through C.L.T opening. Author's Image.

Figure 161 C.L.T openings offset from masonry openings. Author's Image.

Figure 162 Existing openings concealed by laminated timber. Author's Image.

Figure 163 C.L.T panel next to masonry ruins. Author's Image.

Figure 164 Mono-pitch roof in place of existing gable. Author's Image.

Figure 165 Laminated timber projects above existing masonry. Author's Image.

Figure 166 Laminated timber addition at rear of site. Author's Image.

Figure 167 C.L.T inserted within masonry exterior walls. Author's Image.

Figure 168 Introduction of mezzanine floor level to reduce the industrial scale of the building and re-inhabit the space. Author's Image.

Figure 169 Geometry introduced into existing rectilinear grid. Author's Image.

Figure 170 Integrated design strategies showing how laminated timber could be used in the adaptive reuse of the former manure and tallow works into a honey factory. Author's Image.

Figure 171 Site plan axonometric at August review. Author's Image.

Figure 172 Long section through whole site at August review. Author's Image.

Figure 173 Developed site plan. Author's Image.

Figure 174 Long elevation along whole facade. Author's Image.

Figure 175 Front of factory with two protrusions. Author's Image.

Figure 176 Rear of factory with new addition. Author's Image.

Figure 177 New mono-pitch roof line visible on front and rear additions. Author's Image.

Figure 178 Approaching the factory from south. Author's Image.

Figure 179 Factory with sliding doors open. Author's Image.

Figure 180 Exploded axonometric showing existing masonry, structural laminated timber and roof. Author's Image.

Figure 181 Void tests in floor diaphragm. Author's Image.

Figure 182 Structural wall and staircase development. Author's Image.

Figure 183 Honey factory floor plan development. Author's Image.

Figure 184 Freezing chambers extension. April 2017. Author's Image.

Figure 185 Waima heritage precinct master plan. Author's Image.

Figure 186 Site topography. Author's Image.

Figure 187 Original site plan. Author's Image.

Figure 188 Existing ruins. Author's Image.

Figure 189 Zones. Author's Image.

Figure 190 Circulation. Author's Image.

Figure 191 Tokomaru Bay Honey Co-operative site plan. Author's Image. 
Figure 192 Tokomaru Bay Honey Co-operative axonometric. Author's Image.

Figure 193 Honey factory, first floor plan. Author's Image.

Figure 194 Honey factory, ground floor plan. Author's Image.

Figure 195 Long section through honey factory, visitors centre, nursery and ruins. Author's Image.

Figure 196 New opening. Author's Image.

Figure 197 Existing opening. Author's Image.

Figure 198 Opening in ruins. Author's Image.

Figure 199 Open plan office space, honey by products below. Author's Image.

Figure 200 Honey extraction room. Author's Image.

Figure 201 Packing room. Author's Image.

Figure 202 Glulam beam, C.L.T floor diaphragm, C.L.T roof diaphragm against two storey U.R.M wall. Author's Image.

Figure 203 Glulam beam to existing roof truss on left of U.R.M wall. Internal gutter above portal frame on right of U.R.M wall. Author's Image.

Figure 204 Glulam frame with C.L.T roof diaphragm next to single storey U.R.M wall. Author's Image.

Figure 205 Tokomaru Bay wharf and freezing works. April 2017. Author's Image.

Figure 206 Tokomaru Bay Honey Co-operative axonometric. Author's Image.

Figure 207 Mono-pitch roof forms indicate what is new and contrast the existing gable roof lines. Author's Image.

Figure 208 Existing masonry is visible between portal frames. Author's Image.

Figure 209 Adaptive reuse of ruins shows layers of history. Author's Image.

Figure 210 High windows allow day light into internal spaces. Author's Image.

Figure 211 Openings that impact user interaction between inside and out.

Figure 212 Laminated timber enabling new program to occur.

Figure 213 Tokomaru Bay wharf. April 2017. Author's Image.

Figure 214 Iteration 5: design strategy experimentation. 
9.3 Appendices

Appendix 1: Site Analysis

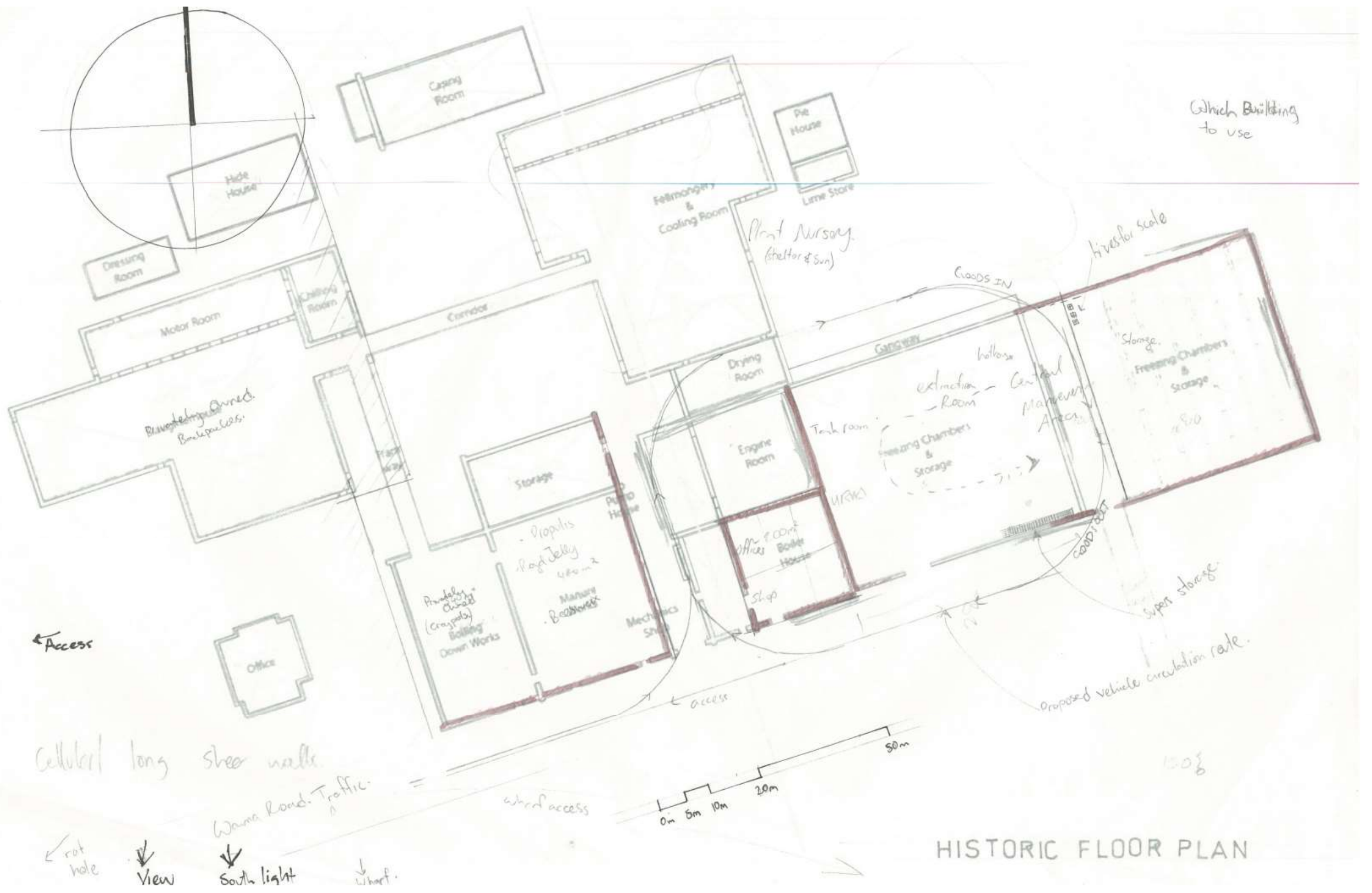

158 
Appendix 2: Site Analysis

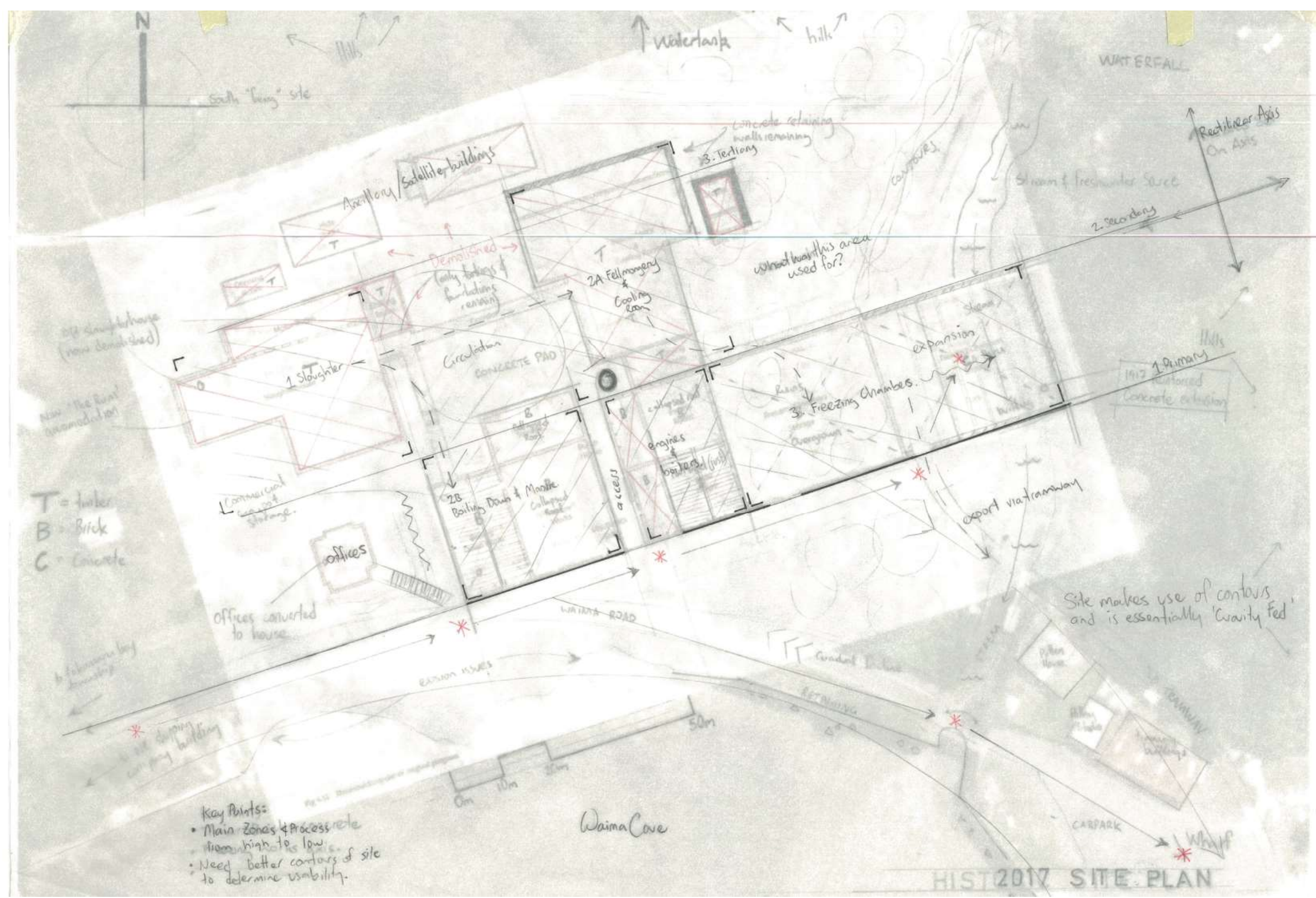


Appendix 3: November Review Panels

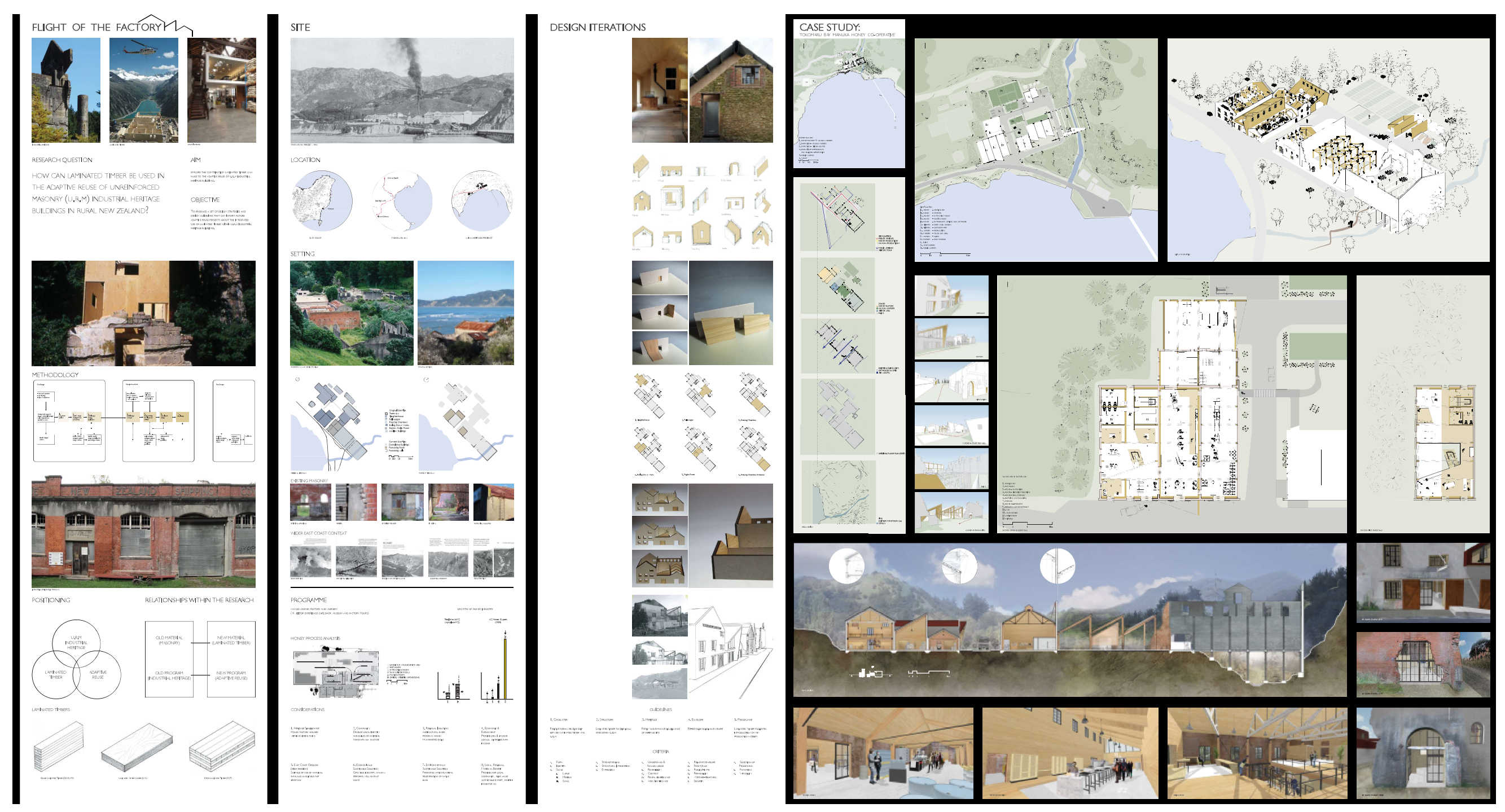

